\title{
Food Security Policy Impact Analysis
}

Citation for published version (APA):

Abuelhaj, T. (2018). Food Security Policy Impact Analysis: The Econometrics of Cash and Food Assistance Cost Effectiveness . [Doctoral Thesis, Maastricht University]. Boekenplan. https://doi.org/10.26481/dis.20180619ta

Document status and date:

Published: 01/01/2018

DOI:

10.26481/dis.20180619ta

Document Version:

Publisher's PDF, also known as Version of record

\section{Please check the document version of this publication:}

- A submitted manuscript is the version of the article upon submission and before peer-review. There can be important differences between the submitted version and the official published version of record.

People interested in the research are advised to contact the author for the final version of the publication, or visit the DOI to the publisher's website.

- The final author version and the galley proof are versions of the publication after peer review.

- The final published version features the final layout of the paper including the volume, issue and page numbers.

Link to publication

\footnotetext{
General rights rights.

- You may freely distribute the URL identifying the publication in the public portal. please follow below link for the End User Agreement:

www.umlib.nl/taverne-license

Take down policy

If you believe that this document breaches copyright please contact us at:

repository@maastrichtuniversity.nl

providing details and we will investigate your claim.
}

Copyright and moral rights for the publications made accessible in the public portal are retained by the authors and/or other copyright owners and it is a condition of accessing publications that users recognise and abide by the legal requirements associated with these

- Users may download and print one copy of any publication from the public portal for the purpose of private study or research.

- You may not further distribute the material or use it for any profit-making activity or commercial gain

If the publication is distributed under the terms of Article $25 \mathrm{fa}$ of the Dutch Copyright Act, indicated by the "Taverne" license above, 


\title{
Food Security Policy Impact Analysis: The Econometrics of
}

Cash and Food Assistance Cost Effectiveness

\author{
Tareq Abuelhaj
}



Food Security Policy Impact Analysis:

The Econometrics of Cash and Food

Assistance Cost Effectiveness 
(C) 2018, Tareq Abuelhaj

ISBN: 978-90-8666-451-1

Published by Boekenplan, Maastricht www.boekenplan.nl

All rights reserved. No part of this publication may be reproduced, stored in a retrieval system, or transmitted in any form or by any means, electronic, mechanical, photocopying, recording or otherwise, without the written permission from the author. 


\title{
Food Security Policy Impact Analysis: The Econometrics of Cash and Food Assistance Cost Effectiveness
}

\author{
DISSERTATION \\ to obtain the degree of Doctor at the Maastricht University, \\ on the authority of the Rector Magnificus, \\ Prof. Dr. Rianne M. Letschert \\ in accordance with the decision of the Board of Deans, \\ to be defended in public \\ on Tuesday 19 June 2018, at 12:00 hours
}

by

Tareq Abuelhaj 


\section{Supervisors:}

Prof. Dr. Cathal O'Donoghue

Prof. Dr. Franziska Gassmann

\section{Assessment Committee:}

Prof. Dr. Pierre Mohnen

(Chairman)

Dr. Jason Loughrey

(Teagasc Rural Economy and Development Centre)

Dr. Bruno Martorano

Prof. Dr. Remco Oostendorp

(Vrije Universiteit Amsterdam, School of Business and Economics \& Tinbergen Institute \& Amsterdam Centre for World Food Studies) 


\section{Preface and Acknowledgements}

This $\mathrm{PhD}$ would not have been possible without the tremendous support of my colleagues and friends in the Iraqi Government. I am particularly grateful to Dr. Medhi Al Alaq, the former Deputy Minister of Planning, Dr. Jamal Ameen, Senior Advisor to the Kurdistan Minister of Planning, Ms. Najla Ali Murad, Director of Poverty Reduction Strategy Secretariat and Mr. Qusay Raoof Abdulfatah, Director of Living Conditions Statistics in the Central Organisation for Statistics and Information Technology. Their dedication to their work and commitment to evidence-based development for Iraq in spite of difficult professional and living conditions was truly inspiring. I was humbled by their confidence in me and their openness to collaboration. These people inspire hope that Iraq can build a positive and inclusive future.

I would also like to acknowledge the mentorship and encouragement given by Mr. Edward Kallon, then Representative and Country Director for the United Nations World Food Programme in Iraq. I hope that the findings from this research can inform WFP's approach to food assistance in Middle Income Countries, in the Arab region and beyond. I am also indebted to other colleagues in WFP, including Jane Pearce, then Senior Policy Advisor at the WFP in Iraq and David Ryckembusch, Senior Programme Advisor at the WFP in Rome, as well as Fadel El Zubi, Country Director for the United Nations Food and Agriculture Organisation in Iraq.

A great deal of gratitude is owed to my supervisors, Prof. Dr. Cathal O'Donoghue and Prof. Dr. Franziska Gassmann, who provided the guidance and direction from start through to the critical final stages, for which I am much indebted. I am also grateful to the director of the dual career PhD programme in Governance and Policy Analysis (GPAC2) of the Maastricht Graduate School of Governance, 
Maastricht University/UNU-MERIT, Dr. Mindel van de Laar, for her patient guidance throughout the $\mathrm{PhD}$ process.

Last but not least, I am grateful to my family for enduring this long and absorbing process, giving me the space and the support to pursue this research. My mother and father, Sulaima and Sameer Abu El Haj, and my wife, Francine Pickup, have provided encouragement throughout. I am also thankful to my three children, Nour, Yasmine and Adam, who have been very patient with me throughout the time that it has taken to complete this research when I shut myself away in my office instead of playing and who can now talk convincingly about the merits of food and cash transfers. 


\section{Table of Contents}

Preface and Acknowledgements .............................................................v

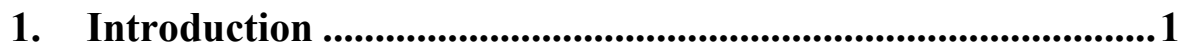





1.3. Contribution and Structure of the Study ...................................... 16



2. Price Opinion Data in Subsidized Economies: Empirical Evidence from Iraq .................................................................................224



2.2. Price data in the welfare analysis literature..................................26

2.3. Analytical Approach and Model Specification ..............................33

2.4. Country Context and Data Sources ................................................43

2.5. Model Results and Diagnosis..................................................... 49

2.6. Implications for welfare analysis in Iraq......................................53







3. Ex Ante Cost Effectiveness of Cash and Food Transfers......69



3.2. Cost effectiveness of cash and food transfers ..............................73

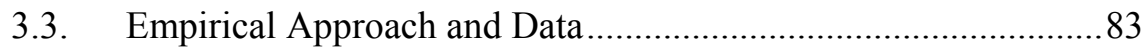



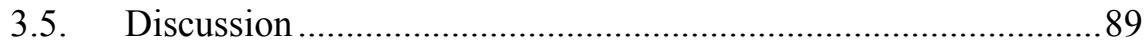

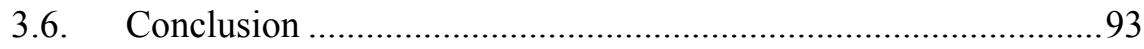

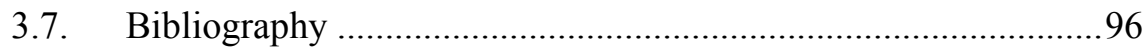




\section{Estimating Food and Nutrient Demand Elasticities in Iraq101}







4.4. Results: Food and Nutrient Demand Elasticities in Iraq ............123







5. Ex Ante Microsimulation of Food Security Policy Options 160



5.2. Theoretical Food Security Framework and the Iraqi Context....163

5.3. Methodology and Data..............................................................167



5.4.1. Impact of PDS Reform on Welfare......................................182

5.4.2. Impact of PDS Reform on Food Security ..............................188

5.4.3. Nutritional Cost Effectiveness Analysis of Cash and Food



5.4.4. Simulated Impact of Cash and Food Vouchers .....................200









7. Valorisation Addendum ......................................................2237



10. Maastricht Graduate School of Governance Dissertation






\section{Introduction}

\subsection{Motivation and Contribution}

The legitimacy of governments is often believed to be fundamentally linked to their ability to ensure food security for their citizens (Smith, 1997). Accordingly, it is no surprise that governments in most countries play a major role in maintaining food security, often through price support or food consumption subsidies aiming to keep food price below market price (Pinstrup-Andersen, 1988).

However, national food assistance ${ }^{1}$ schemes have witnessed a profound transformation over the past few decades. Mechanisms such as national grain reserves, agricultural input subsidies and food consumption subsidies, which were mainstays of the 'old social protection agenda' (Devereux, 2016), eventually fell under pressure to reform during 1980s and 1990s - the era of structural adjustment programs of the International Monetary Fund (IMF) and the World Bank seeking trade liberalization and reallocation of budget compositions (Heller, Bovenberg, Catsambas, Chu, \& Shome, 1988). The universal, untargeted nature of food consumption subsidies was deemed an inefficient use of resources (Pinstrup-Andersen, 1988; FAO, 1994) and were argued to distort markets, induce disincentives for agricultural production and private sector food trade and suffered inefficiencies in their public sector managed supply chains (del Ninno, Dorosh, \& Subbarao, 2007).

Since then, the 'new social protection agenda' has become dominated by social transfers, with cash transfers increasingly displacing food assistance (Devereux, 2009). Conditional Cash Transfer programs were introduced and scaled up by Latin American Countries in response to the negative effects of structural adjustment programs (de Lettenhove, 2012). In some cases, these emerged as responses to mitigate the impact of eliminating food subsidies.

${ }^{1}$ Food assistance is defined as the set of interventions designed to provide access to food to vulnerable and food insecure populations (Omamo et al., 2010) 
In Mexico, the World Bank argued to transform the generalized food consumption subsidy to a targeted subsidy as a condition for an agricultural adjustment loan. Consequently, Mexico replaced the universal tortilla subsidies to a poverty-targeted subsidy (Tortibonos) (Weaving, 1996), which were eventually phased out and replaced by poverty targeted conditional cash transfers within the framework of PROGRESA $^{2}$ (Schanbacher, 2010). The removal of tortilla subsidies and their replacement with a poverty targeted conditional cash transfer was viewed as a success (Sdralevich, Sab, Zouhar, \& Albertin, 2014), with studies identifying welfare gains among the poor as a result of the programs (Skoufias, 2005; Ruiz-Arranz, Davis, Handa, S., Stampini, \& Winters, 2006).

However, the transition from food consumption subsidies to cash transfers left poorer Mexicans vulnerable to food insecurity particularly during the global soaring food price crisis and contributed to the tortilla riots witnessed in 2007 (Attanasio, Di Maro, Lechene, \& Phillips, 2013). Similarly, the experience of many African countries with structural adjustment programs and subsidy elimination promoted by International Financial Institutions and Donor countries in the 1980s and 1990s was also mixed, with average growth in consumption and reduction in inequality masking significant rearrangement of subnational distribution of wealth (Christiaensen, Demery, \& Paternostro, 2002).

The Food and Agriculture Organization of the United Nations (FAO) argued that growth resulting from the structural adjustment programs in Africa did not lead to improved food security (Kidane, Maetz, \& Dardel, 2006) and claims have been made of heightened food insecurity in many sub-Saharan African countries following the drawback of food subsidies and other state support mechanisms (Devereux, 2016).

The impacts of eliminating or replacement of universal food consumption subsidies with targeted assistance on nutrient intakes,

${ }^{2}$ Mexico's flagship conditional cash transfer program, which later became known as Oportunidades. 
whether among the poorest in sub-Saharan Africa or beyond, is difficult to gauge particularly given the almost exclusive reliance on money metric measures of welfare by the World Bank and the reliance on national aggregate food supply indicators by the FAO. However, where they do exist, indicators of household food security in general, and nutrient intake in specific, often reveal deteriorating food security - such as falling nutrient intake and rising malnutrition following the reduction of consumer subsidies in Nigeria in the mid 1980s (Igdebioh, 1990).

In Sri Lanka, the reduction in food consumption subsidies starting in the late 1970s had led to the reduction in nutrient intake among the poorest decile from 2,150 kilocalories daily ${ }^{3}$ in 1970 down to 1,566 in 1982 (Sahn, 1987), while at the same time, the IMF argued that the nutritional effects of reducing food subsidies in Sri Lanka were "probably negligible" (Heller, Bovenberg, Catsambas, Chu, \& Shome, 1988). Similarly, the elimination of food subsidies in Iran and the replacement with universal unconditional cash transfers was considered to be "partially successful" by the IMF (Sdralevich, Sab, Zouhar, \& Albertin, 2014) and estimated to have led to reduced poverty and inequality (Enami, Lustig, \& Taqdiri, 2016) though this is in stark contrast with food security research indicating falling food consumption and rising food budget shares following the subsidy elimination (Hosseini, Charvadeh, \& Salami, 2016; Pasdar, Rezaei, Darbandi, \& Sharafi, 2016). As recently as December 2017, international media reported on popular disturbances and riots in Iran over persistent unemployment and high prices of basic food goods (Associated Press, 2017).

For World Bank supported structural adjustment programs, the discrepancy in reported welfare results and reported food security outcomes is not surprising as over " 85 percent of the Bank's agricultural adjustment loans have completely ignored food security" (Weaving, 1996). However, the mismatch in evidence where improvements in economic welfare are contradicted by evidence of persistent or deteriorating food insecurity is not unique to the area of

${ }^{3}$ Per adult equivalent. 
food subsidy reforms. For example, the 2010 UN progress report on the Millennium Development Goals states that "progress on poverty reduction is still being made" and "the developing world as a whole remains on track to achieve the poverty reduction target by 2015 ", while also stating that "the number of people who are undernourished has continued to grow" (UN, 2010) and gains in reduction of undernourishment in the 1990s somewhat reversed in the few years running up to 2010 (Omamo, Gentilini, \& Sandström, 2010). Indeed, research on the relationship between growth and nutrition shows that while growth helps reduce undernourishment, it is not sufficient to reduce child malnutrition or micronutrient malnutrition (Ecker, Breisinger, \& Pauw, 2012). The notion of a mismatch between welfare, in its economic sense, and actual experiences of deprivation is further supported by the growing body of literature revealing disparities between monetary poverty and multidimensional poverty (Tran, Alkire, \& Klasen, 2015).

International food aid has also witnessed significant transformations during the past 20 years. Until the late 1990s, international food aid was largely limited to a system of in kind food donations from donor countries with agricultural surpluses to recipient countries experiencing chronic or acute food deficits (Barrett \& Maxwell, 2005). The bulk of in kind food assistance took the form of bilateral donations from donor countries to recipient countries which in turn monetized the food or in some cases directly distributed the food to vulnerable groups. However, the share of bilateral food donations from total global food aid has dropped significantly in favor of a greater reliance on multilateral food aid, through mainly the World Food Programme (WFP) - a United Nations agency (Barrett, Binder, \& Steets, 2011). Rising global food prices and alterations to agricultural production subsidies in major donor countries led to a reduction in total in kind food donations and a greater focus on multilateral food aid.

The scarcity of in kind food donations meant that in kind food aid has become increasingly limited to acute humanitarian emergencies, with the share of total international food aid allocated to emergency response rising from $20 \%$ in the 1980 s to $75 \%$ in 2008 . This, coupled with an increase in the numbers of food insecure people, spurred 
greater emphasis on improved needs assessment and targeting food aid to the most in need (Barrett, Binder, \& Steets, 2011). Food aid donors argued for improved targeting on grounds of efficient use of limited resources, but also on the grounds of limiting adverse effects of international in kind food assistance, particularly in displacing commercial food imports (Barrett, 2002).

Greater flexibility on the part of traditional food aid donors, particularly the growing trend of donors willing to donate funds rather than food commodities, provided WFP and other multilateral food assistance agencies the flexibility to rely more on markets closer to the recipient population for the procurement of food and procurement from small scale farmers. In contexts where the recipient population benefits from access to functioning markets, WFP increasingly relied on cash and food voucher transfers to improve recipient's access to food (Devereux, 2008; Lentz, Barrett, \& Gomez, 2013). This transition from a commodity based in kind assistance to alternative transfer modalities such as cash and vouchers has been encouraged by developing country governments and donors alike (Hibrobo, Hoddinott, Margolies, Moreira, \& Peterman, 2012). Consequently, WFP launched new initiatives such as the Cash for Change Initiative, aiming to scale up cash and voucher operations within WFP (WFP, 2011) and the Purchase for Progress (P4P) initiative which aims to strengthening local economies and support the increased resilience and productivity of rural communities by sourcing a proportion of its food purchases from smallholder farmers in developing countries (WFP, 2013a).

The increased reliance on cash and voucher based food assistance coincided with renewed interest in nutrition security and a focus on the nutritional content of food. The 2014 Rome Declaration on Nutrition included recommendations on the inclusion of nutrition objectives in both national social protection systems and humanitarian assistance (FAO, 2014). The reliance on market based food transfer mechanisms allowed the flexibility to go beyond the macronutrient considerations of a food transfer. WFP ventured beyond the macro nutrient considerations of a food basked by integrating micro nutrients into their response analysis process, 
especially that involving deciding on whether to use food, cash or vouchers as the choice of transfer modality (WFP, 2014a).

Another consequence of the increased reliance on cash and vouchers by multilateral organizations in both development and humanitarian interventions is the recognition that social protection systems and food assistance programs serve overlapping goals (Devereux, 2016). While cash transfers are the main social assistance element of national social protection systems, the increased use of cash and vouchers as food assistance mechanisms by WFP and other multilateral organizations blurred the lines between food assistance and social protection (Lentz, Barrett, \& Gomez, 2013) and has provided an avenue for WFP to engage with national social safety nets (Omamo, Gentilini, \& Sandström, 2010). Consequently, countries with large food based safety nets such as India and Iraq have increasingly sought technical assistance from $\mathrm{WFP}^{4}$.

Therefore, while current international food aid and national food assistance programs were shaped by somewhat different influences, spanning different timeframes, they appear to have largely converged on the question of cash versus in kind food assistance. The transition of national food assistance programs towards cash transfers - seen to be more flexible and less paternalistic (Devereux, 2016) - reflects the preferences of economists specifically with regards to maximizing the utility of recipients (Currie \& Gahvari, 2008) and as a means to increase efficiency in government budget allocations and minimize market distortions (Pistrup-Andersen \& Alderman, 1988; Sdralevich, Sab, Zouhar, \& Albertin, 2014).

While in-kind international food aid has also been described as paternalistic as it ignores the preferences of its recipients (Barrett \& Maxwell, 2005), it is arguable that the increased use of cash and vouchers by WFP is not necessarily driven by the sort of economic rationale underlying the trend of replacing national food subsidy schemes with cash transfers. As previously described, global food prices and subsequent changes in the policies of major food aid donor

${ }^{4}$ See for example the case of Iraq (WFP, 2013b) and India (WFP, 2014b). 
countries is what instigated the increased use of cash and voucher transfers in food assistance programs implemented by WFP and other multilateral organizations.

Consequently, past and current WFP Strategic Objectives remain focused on ending hunger and the achievement of food and nutrition security regardless whether through in kind, cash or food voucher transfers (See for example: (WFP, 2017) or (WFP, 2013c). Similarly, traditional WFP indicators for food consumption frequency and dietary diversity remain the main outcome indicators for operations regardless whether they deliver in kind, cash or food vouchers (WFP, 2013d).

However, the addition of new transfer modalities in the food assistance toolbox has not been accompanied by a growth of empirical literature that develops a deeper understanding of the relative merits of these modalities and the unique impacts that each may bring. There is very little research that focuses on the response analysis process applied by food assistance organizations.

Nonetheless, a number of practical tools and guidance notes emerged in the past decade, designed by donors and practitioners, to inform practitioners on when to use cash transfers or in kind food transfers. These include agency specific guidance on cash transfers such as for Oxfam (Creti \& Jaspars, 2006), the International Committee of the Red Cross (ICRC, 2007), Action Contre la Faim (ACF) (ACF, 2007), the World Food Programme (WFP, 2009), the Food and Agriculture Organization (FAO, 2011) as well as donor funding guidelines and toolkits targeting broader audiences of practitioners such as the Market Information for Food Insecurity Response Analysis (MIFIRA; (Barrett, Bell, Lentz, \& Maxwell, 2009)), the guidelines of the European Commission Directorate-General for Humanitarian Aid (ECHO) for funding cash and vouchers in humanitarian emergencies (European Commission, 2009), the Emergency Market Mapping and Analysis (EMMA) toolkit supported by USAID Office for Foreign Direct Assistance (Albu, 2010) and the Overseas Development Institute 'Good Practice Review' on cash transfers in emergencies (Harvey \& Bailey, 2011). 
Since these tools deal with similar questions regarding the choice of transfer modality, it is natural that they share many features; However, here we take special note of three main features common to most ${ }^{5}$ tools and guidance notes. First, the answer to the question of when to use cash assistance or in-kind assistance is primarily governed by the practical consideration of whether food markets are available and accessible to the recipients of cash transfers - and whether these markets function with some degree of efficiency - as well as considerations of institutional and infrastructural readiness and safeguards to safely manage the movement and distribution of cash while limiting the potential for corruption and other fiduciary risks. Second, food voucher transfers are almost always grouped together with cash transfers and are considered "cash-equivalent". Third, very little - if any - consideration is afforded for any potential difference in the impacts of in-kind, cash or food vouchers on food consumption or how they might align with the objectives of the transfer.

These features underline a growing "cash-first" trend among donors and aid organizations (Norad, 2011). This is supported by Southworth's theoretical work extending neoclassical economic theory to the question of food consumption subsidies (1945), which assumes the fungibility of cash and in kind transfers in terms of food consumption responses to the transfers. This means that an in kind food transfer received by a household or an equivalently valued cash transfer would induce the same consumption response - granted that the food transfer is inframarginal (Southworth, 1945). An inframarginal food transfer is less than the quantity the household would normally consume given their preferences and income level. Extramarginal food transfers would, however, constrain the household to consume more than they normally would prefer. Therefore, according to neoclassical economic theory, an

${ }^{5}$ with the exception of those for WFP, FAO and ACF.

${ }^{6}$ This is similar to the World Bank description of vouchers as "near-cash" transfer mechanisms (Grosh, del Ninno, Tesliuc, \& Ouerghi, 2008). 
inframarginal food transfer should be essentially equivalent to an income transfer.

It follows that food insecurity caused mainly by a lack of economic access to food - in other words, poverty - is most effectively responded to using cash transfers, particularly in the presence of efficient markets. This approach offers no additional consideration to any other outcome beyond the 'poverty alleviation' value of the transfer. This is also typical of most traditional national food consumption subsidy schemes, the majority of which did not have specific nutritional objectives (Kumar \& Alderman, 1988) though most common objectives included income transfer and (or) insuring access to a minimum quantity of staple food commodities (PistrupAndersen \& Alderman, 1988).

In contrast, organizations with specific food and nutrition security mandates such as WFP, FAO and ACF do not automatically prescribe cash even in the presence of functioning markets. Rather, these institutions advocate 'considering' cash or a combined cash and food transfer. WFP guidance notes on cash and vouchers specify the undertaking of comparative ex ante cost effectiveness analysis of transfer modalities as 'mandatory' (WFP, 2014a).

Indeed, this is a reasonable requirement whether in the context of designing or reforming a food assistance programme, particularly given that plenty of empirical evidence exists which contradicts Southworth's economic model (Fraker, 1990). This body of empirical evidence regularly shows that households tend to consume more food from a food transfer than they would consume from an equally valued cash transfer - which is often dubbed the 'cash-out puzzle' (Gentilini, 2014).

Despite this, there is no evidence of nutritional cost effectiveness analysis informing reform of national food assistance schemes other than those performed by the Government of Iraq (WFP \& GOI, 2012) and the Libyan Bureau of Statistics and Census (BSC, 2014), both of which were done with technical support from WFP.

Using Iraq as a case study, this dissertation explores the different facets of food assistance that are relevant to the development of ex 
ante cost effectiveness analysis such as (i) approaches to determine the 'income transfer value' of food assistance and (ii) consumer responses to food assistance and cash transfers. This dissertation also explores avenues to incorporate consumer responses to food assistance within the framework of estimating food demand system parameters as a step towards enabling greater understanding of the effects of national food subsidy reform processes on food and nutrient consumption.

\subsection{Country Context}

The Iraqi context is particularly pertinent for this analysis. Iraq, a middle income country with the fourth largest proven crude oil reserves in the world (OPEC, 2017), maintains the largest national food assistance scheme worldwide known as the Public Distribution System (PDS; World Bank, 2007). Iraq's recent history throughout the past forty years has been replete with significant economic and political shocks. Although Iraqi food assistance policies have evolved over the years to address the needs of Iraqi citizens, the effects of these policies remain underserved by scholarly research despite their significant implications for Iraqi citizens and Government as well as for multilateral humanitarian and development organizations.

Given the high reliance on oil revenue, the Iraqi economy is highly dependent on international events and is vulnerable to isolation from the world economy. The 1970s and the global oil crisis and the resulting rise in oil revenue brought Iraq significant wealth and improvements in the living conditions and wellbeing of the Iraqi population. GDP steadily and consistently rose throughout the seventies allowing for the improvement of standard of living with a six-fold increase in nominal per capita income between 1973 and 1979 (Abdullah, 2011). By the end of the decade, Iraq boasted almost universal levels of primary school enrolment (UN \& WB, 2003) and significantly reduced infant mortality which fell from 129 per 1000 live births in 1960-1965 to 57 in 1975-1980 (United Nations Population Division, 2012). 


\section{Figure 1: Iraqi GDP per capita 1970 - 2016}



Source: Iraq Central Organization for Statistics and Information Technology (COSIT)

The Iran-Iraq war dominated the 1980s which led to reversals of some of the economic and social gains of the 1970s. Nonetheless, Iraq benefited from strong support from the United States during this period. Trade between the United States and Iraq grew significantly during this period, with Iraq receiving billions of US Dollars in US Credit Guarantees and grants which was used to acquire agricultural goods from the United States (Schnepf, 2004).

Figure 2: Dietary Energy Supply and Agricultural Imports - 3 year moving average (1975-2000)



Source: Data extracted from (Schnepf, 2004) 
Dietary Energy Supply soared during this period (Figure 2) and infant mortality rate continued its downward trend to reach 37 deaths per 1000 live births in 1985-1990 (United Nations Population Division, 2012). The number of schools and the number of students enrolled declined during this period (COSIT, 2006).

The 1990s was a devastating decade for Iraq. Following the end of the Iran-Iraq War, Iraq accused Kuwait and the United Arab Emirates of waging "economic war" on Iraq by exceeding their oil production quotas set by OPEC causing a 30 percent fall in oil prices (Alnasrawi, 1994). The Iraqi invasion of Kuwait drew condemnation in a UN Security Council Resolution (UNSCR 660), which authorized the military campaign of the American-led coalition in what has become known as the 'First Gulf War'. The aerial campaign of the coalition forces destroyed military and civilian infrastructure (Alnasrawi, 1994) essentially relegating Iraq to a 'pre-industrial age' (UN, 1991). Equally devastating, however, was the UN sanctions imposed by UNSCR 661 which banned all transactions with Iraq, cutting off its main source of revenue and foreign reserves. Iraq - which by that time imported about 70 percent of its food requirements - had no means to acquire food internationally and its local production severely limited. The Iraqi private sector was devastated and markets collapsed, with the cost of basic goods rising by over 1000 percent (UN, 1991). Dietary energy supply fell by 28 percent in 1991 and continued to fall until after the first food shipments under the Oil For Food Programme (OFFP) began to arrive in 1997 (Schnepf, 2004).

\section{The Iraqi Public Distribution System (PDS)}

Food supply in Iraq has long been regulated through state intervention in food importation, local production and price setting policies. In 1961, the Government of Iraq passed Law 86/1961 ${ }^{7}$ establishing the Grain Trade Regulatory Authority under the Ministry

${ }^{7}$ This law and other Iraqi Laws and Government Decisions cited in this text are publically available at http://www.iraqld.iq/ 
of Trade ${ }^{8}$ that had the authority to procure grain, including wheat and rice, locally and internationally and to set market prices. While the Regulatory Authority influenced overall supply of food and prices, the Government did not restrict private sector activity in the food markets and even relied on private sector supply chains to market commodities procured by the Regulatory Authority.

However, with the collapse of the private sector and severe shortfalls in food supply following the sanctions in 1990, the Iraqi Revolutionary Council Decision No. 442/1990 and Law 136/1991 were passed giving the Ministry of Trade (MOT) the monopoly in grain trade. Food supply shortages were so severe that the Iraqi Revolutionary Council passed decisions specifying the death penalty for anyone proven to hoard food commodities or monopolize food trade in Iraq (Revolutionary Council Decision No. 315/1990) and up to 15-year prison sentences for Iraqi traders proven to sell food commodities for higher than their official price (Revolutionary Council Decision No. 365/1990).

Naturally, under such conditions, rationing of food was inevitable. A centrally managed system of food distribution and rationing - known as the Public Distribution System (PDS) - emerged from the reality of wartime and sanctions induced scarcity in basic food supplies. While no law or Government decision can be found that governs or specifically defines the PDS, the collection of laws and revolutionary council decisions issued before and during the sanctions enabled the Government of Iraq to establish the PDS which continues to this day.

The basket of rationed goods distributed through the PDS did change over time. The basket consisted mainly of food items, although some basic hygiene-related non-food items were also rationed through the PDS (Table 1). From 1990 until 1998, the PDS food basket was designed to provide 1,400 kilocalories per person daily, though this was revised upwards in 1998 (Independent Inquiry Committee, 2005).

${ }^{8}$ Over the years, subsequent amendments to the law linked the authority to the Ministry of Trade or the Ministry of Economy. 
Table 1: Composition of the PDS Basket: 1991 - Today

\begin{tabular}{lcccc} 
& \multicolumn{3}{c}{ Distribution per person/month (kg) } \\
& Pre-OFFP & OFFP & Post 2003 & Post 2009 \\
\cline { 2 - 5 } Wheat Flour & 7 & 9 & 9 & 9 \\
Rice & 1.25 & 2.5 & 3 & 3 \\
Sugar & 0.5 & 2 & 2 & 2 \\
Tea & 0.1 & 0.15 & 0.2 & --- \\
Vegetable ghee or oil (liter) & 0.75 & 1 & 1.25 & 1.25 \\
Dried beans & 0.2 & 0.2 & 0.5 & --- \\
Salt & 0.1 & 0.15 & 0.15 & --- \\
Powdered milk & 0 & 0.5 & 0.5 & --- \\
Soap & 0.125 & 0.25 & 0.25 & --- \\
Detergent & 0.25 & 0.35 & 0.35 & --- \\
Ration for Infants up to one year & & & \\
Infant Formula & 1.8 & 2.7 & 2.7 & 2.7 \\
Cereal & 0.9 & 0.9 & 0.9 & --- \\
Soap & 0.125 & 0.25 & 0.25 & --- \\
Detergent & 0.25 & 0.35 & 0.35 & --- \\
\hline Sources: (USAID, & & & & \\
\hline
\end{tabular}

Sources: (USAID, 2006); (WFP \& GOI, 2012)

The prevalence of underweight children rose significantly through the first half of the 1990s to peak at 19 percent in the three northern Governorates and 23.4 percent in the central and southern Governorates, though with the expansion of the PDS food basket un the OFFP, the prevalence fell down to 8.6 percent in the three northern Governorates and 9.4 percent in the central and southern Governorates in 2002 (Independent Inquiry Committee, 2005). The PDS was credited with preventing widespread starvation in Iraq (Schnepf, 2004).

Following the Second Gulf War in 2003 and the total collapse of Government services, WFP assumed full responsibility for the PDS supply chain and distribution in all Governorates of Iraq. In 2004, WFP handed responsibility for the PDS back to the Iraqi Ministry of Trade and immediately embarked on an analysis of PDS reform options together with the World Bank (WFP, 2005). The PDS supply chain frequently faltered and households reported not receiving all or part of their food rations. Despite this, subsequent WFP surveys in 2005 and 2007 report that 95 percent of Iraq households preferred to 
maintain the in-kind food basket than to have it replaced with a cash transfer (WFP, 2006; WFP, 2008).

In 2009, the Government of Iraq established the High Committee for PDS Reform and launched a study, supported by the World Bank, to assess possible options for reform. The PDS reform committee report included a number of recommendations, including the immediate reduction of the PDS food basket to include only wheat flour, rice, vegetable oil, sugar and infant formula (See Table 1) as well as the gradual elimination of the PDS and its replacement with a cash transfer within the framework of the national Social Safety Net. These recommendations were approved by the Iraqi Council of Ministers Decision No. 369/2009 (GOI, 2009). Nevertheless, additional analysis of reform option performed with technical support from WFP, including some rudimentary comparative cost effectiveness analysis, revealed that cash transfers were less cost effective than food vouchers in ensuring food consumption (WFP \& GOI, 2012). Subsequently, the Government of Iraq decided to study the possibility of establishing electronic food vouchers in collaboration with WFP (WFP, 2013b).

However, Iraq's turbulent past caught up with it yet again in January 2014, when the Islamic State in Iraq and the Levant (ISIL) - a terrorist organization - ceased control of Falluja, a major city in Iraq's Anbar province and continued to violently cease territory in western and north western Iraq until it held up to 40 percent of the area of Iraq (Michaels, 2016). The sudden onset of violence in 2014 and its intensity - which continued until mid 2017 - essentially shelved all Iraqi plans to reform the PDS as all national efforts were directed towards the liberation of territories occupied by ISIL.

By July 2017, Iraqi security forces regained most of the territory lost to ISIL as the city of Mosul, the second largest city in Iraq which fell under control of ISIL was declared liberated - marking the end of a long and violent military campaign (Arango \& Michael, 2017). Soon afterwards, the PDS reform agenda emerged as a priority once again and the Iraqi Parliament announced the first reading of a Law designed to legislate the transition of the PDS to an electronic food transfer mechanism (Iraqi Parliament, 2017). 


\subsection{Contribution and Structure of the Study}

This dissertation contributes to greater understanding of the relative merits of cash and food transfers in the context of national safety nets as well as international humanitarian and international aid. The approach of the dissertation is to probe specific facets of the questions surrounding the effectiveness of cash versus food transfer modalities such as the problem of valuing food subsidies, understanding the implications of different consumption responses due to alternative transfer modalities and estimating food demand parameters in the presence of subsidies and rationing. As a result, the dissertation contributes to the development of a stylized nutritional cost effectiveness analysis approach specific to cash and food vouchers and provides evidence on the food security and welfare costs and benefits of replacing food consumption subsidies in Iraq with cash or food voucher transfers.

Although the analysis performed in this dissertation relies primarily on data from Iraq, its relevance extends to contexts well beyond Iraq. The debate surrounding effectiveness of cash versus food transfer is one that many developed and developing countries continue to grapple with. The literature on the cash-out puzzle began decades ago in the United States and remains active to this day - increasingly so among international organizations and donors. Importantly, humanitarian organizations such as WFP and others have expressed goals to increase their cash and voucher activities even in emergencies and donors are increasingly asking difficult questions regarding the cost effectiveness of different transfer modalities. Without doubt, the research presented below will shed some light on this lively debate.

This dissertation consists of four distinct but linked studies ${ }^{9}$. Chapters two to five address distinct research questions, though all

\footnotetext{
${ }^{9}$ Each chapter, including this introduction, has its own bibliography and appendices.
} 
collectively contribute to the overall research domain of this dissertation.

Chapter 2 explores the challenge of how to estimate the value of food assistance, focusing on the appropriateness of respondent-estimated market price opinion data of the commodities included in the PDS food basket. Estimating the value of the PDS is an important step in determining the impact of PDS reform. Specifically, this chapter explores the differences between paid prices, respondent-estimated market prices and observed market prices and how they impact the measurement of poverty and food deprivation.

Chapter 3 looks at international evidence from the US and developing countries and contributes additional empirical evidence on the nutritional cost effectiveness of cash versus food transfers as part of food assistance programmes. Specifically, this chapter explores how household demand for food following a food transfer differs from that following a cash transfer and how that difference can be employed to measure the ex-ante cost effectiveness of cash and food transfers.

Chapter 4 builds on the findings from Chapters 2 and 3 to estimate a completed food demand system for Iraq - the case study country for this dissertation. Applying quantitative food demand modelling approaches, this chapter investigates the dynamics of demand for food and nutrients in the presence of food consumption subsidies.

Chapter 5 applies microsimulation methods to assess the expected impacts of food consumption subsidy reform on welfare and food security and explores the comparative cost effectiveness of alternative transfer modalities such as cash and food vouchers.

Chapter 6 concludes with a discussion on the main findings from the studies and explores opportunities for future research. 


\subsection{Bibliography}

Abdullah, T. (2011). Short History of Iraq. New York: Routledge. ACF. (2007). Implementing Cash-based Interventions. Action Contre la Faim.

Albu, M. (2010). The emergency market mapping and analysis toolkit. Rugby: Practical Action Publishing Ltd.

Alnasrawi, A. (1994). The Economy of Iraq: Oil, Wars, Destruction of Development and Prospects, 1950-2010. Greenwood Press.

Arango, T., \& Michael, G. (2017, July 9). Iraqi Prime Minister Arrives in Mosul to Declare Victory Over ISIS. The New York Times.

Associated Press. (2017, December 28). Iranians Protest Rising Food Prices. Retrieved from New York Times Online: https://www.nytimes.com/2017/12/28/world/middleeast/irania ns-protest-rising-food-prices.html

Attanasio, O., Di Maro, V., Lechene, V., \& Phillips, D. (2013). Welfare consequences of food prices increases: Evidence from rural Mexico. Journal of Development Economics, 104, $136-151$

Barrett, C. (2002). Food aid and commercial international food trade. Background paper prepared for the Trade and Markets Division, Organisation for Economic Co-operation and Development.

Barrett, C., \& Maxwell, D. (2005). Food Aid after Fifty Years: Recasting its Role. London: Routledge.

Barrett, C., Bell, R., Lentz, E., \& Maxwell, D. (2009). Market information and food insecurity response analysis. Food Security, 1(2), 151-168.

Barrett, C., Binder, A., \& Steets, J. (2011). Chapter 1: Uniting on food assistance: The case for transatlantic cooperation. In C. Barrett, A. Binder, \& J. Steets (Eds.), Uniting on food assistance: The case for transatlantic cooperation. London: Routledge.

BSC. (2014). Food Security and Food Subsidy Reform in Libya. Tripoli: Libyan Bureau of Statistics and Census (BSC). 
Christiaensen, L., Demery, L., \& Paternostro, S. (2002). Growth, Distribution and Poverty in Africa: Messages from the 1990s. Poverty Dynamics in Africa. Washington, DC: World Bank.

COSIT. (2006). Statistical Yearbook - 2006. Baghdad: Central Organization for Statistics and Information Technology.

Creti, P., \& Jaspars, S. (2006). Cash-Transfer Programming in Emergencies. Oxford: Oxfam.

Currie, J., \& Gahvari, F. (2008). Transfers in Cash and In-Kind: Theory Meets the Data. Journal of Economic Literature, 46(2), 333-383.

de Lettenhove, M. (2012). Conditional Cash Transfers in Latin America: Impact, scope and limitations. Reflets et perspectives de la vie économique(2), 5-18.

del Ninno, C., Dorosh, P., \& Subbarao, K. (2007). Food aid, domestic policy and food security- Contrasting experiences from South Asia and sub-Saharan Africa. Food Policy, 32, 413-435.

Devereux, S. (2008). Innovations in the Design and Delivery of Social Transfers: Lessons Learned from Malawi. Concern Worldwide Policy Paper. London: Concern Worldwide.

Devereux, S. (2009). Social Protection for Agricultural Growth in Africa. Growth and Social Protection Working Paper No. 6. Brighton: Future Agricultures Consortium.

Devereux, S. (2016). Social protection for enhanced food security in sub-Saharan Africa. Food Policy, 60, 52-62.

Ecker, O., Breisinger, C., \& Pauw, K. (2012). Growth is good, but is not enough to improve nutrition. In S. Fan, \& R. PandyaLorch (Eds.), Reshaping Agriculture for Nutrition and Health (pp. 47-54). International Food Policy Research Institute.

Enami, A., Lustig, N., \& Taqdiri, A. (2016). Fiscal Policy, Inequality and Poverty in Iran: Assessing the Impact and Effectiveness of Taxes and Transfers the Poor in the Developing World. Center for Global Development Working Paper No. 442. Washington, DC: Center for Global Development.

European Commission. (2009). The use of cash and vouchers in humanitarian crises: DG ECHO funding guidelines. Brussels: European Commission.

FAO. (1994). Indian experience on household food and nutrition security. Regional Expert Consultation. Bangkok: Food and Agriculture Organization. 
FAO. (2011). A Response Analysis Framework for Food And Nutrition Security Interventions At Inter-Cluster And Cluster Level. Rome: The Food and Agriculture Organization.

FAO. (2014). Second International Conference on Nutrition Conference. Outcome Document: Framework for Action. Rome: Food and Agriculture Organization.

Fraker, T. (1990). Effects of Food Stamps on Food Consumption: A Review of the Literature. Washington, DC: Mathematica Policy Research, Inc.

Gentilini, U. (2014). Our Daily Bread: What is the Evidence on Comparing Cash versus Food Transfers? Social Protection and Labour Discussion Paper No. 1420. Washington, DC: World Bank.

GOI. (2009). Iraq Council of Ministers Decision No. 369. Baghdad: Government of Iraq. Retrieved from http://www.cabinet.iq/ Harvey, P., \& Bailey, S. (2011, June). Cash transfer programming in emergencies. Humanitarian Practice Network, Overseas Development Institute.

Heller, P., Bovenberg, A., Catsambas, T., Chu, K., \& Shome, P. (1988). The Implications of Fund-Supported Adjustment for Poverty. IMF Occasional Paper No. 58. Washington, DC: International Monetary Fund.

Hibrobo, M., Hoddinott, J., Margolies, A., Moreira, V., \& Peterman, A. (2012). mpact Evaluation of Cash, Food Vouchers, and Food Transfers among Colombian Refugees and Poor Ecuadorians in Carchi and Sucumbíos. International Food Policy Research Institute. Washington, DC: International Food Policy Research Institute.

Hosseini, S., Charvadeh, M., \& Salami, H. (2016). The Effect of Subsidy Reform Program on Food Security in Iran. Iranian Journal of Economic Research, 21(67), 53-82.

ICRC. (2007). Guidelines for Cash-Transfer Programming. Geneva: ICRC and International Federation of Red Cross and Red Crescent Societies.

Igdebioh, S. (1990). Macroeconomic adjustment, food availability and nutrition status in Nigeria: A look at the 1990s. Food Policy, 15(6), 518-524. 
Independent Inquiry Committee. (2005). The Impact of the Oil-ForFood Programme on the Iraqi People. independent Working Group. New York: Independent Inquiry Committee.

Iraqi Parliament. (2017, September). Electronic PDS Card Law: First reading. Retrieved from ttp://ar.parliament.iq

Kidane, W., Maetz, M., \& Dardel, P. (2006). Food security and agricultural development in sub-Saharan Africa Building a case for more public support. Rome: Food and Agriculture Organization.

Kumar, S., \& Alderman, H. (1988). Food Consumption and Nutritional Effects of Consumer-Oriented Food Subsidies. In P. Pinstrup-Andersen (Ed.), Food subsidies in developing countries: costs, benefits, and policy options (pp. 36-48). Baltimore: Johns Hopkins University Press.

Lentz, E., Barrett, C., \& Gomez, M. (2013). On The Choice and Impacts of Innovative International Food Assistance Instruments. World Development, 49, 1-8.

Michaels, J. (2016, May 17). ISIS loses 45 percent of territory in Iraq, 20 percent in Syria. Military Times.

Norad. (2011). We Accept Cash: Mapping Study on the Use of Cash Transfers in Humanitarian, Recovery and Transitional Response. Oslo: The Norwegian Agency for Development Cooperation (Norad).

Omamo, S., Gentilini, U., \& Sandström, S. (2010). Revolution: from food aid to food assistance. Rome: World Food Programme.

OPEC. (2017). Annual Statistical Bulletin. Vienna: Organization of the Petroleum Exporting Countries (OPEC).

Pasdar, Y., Rezaei, M., Darbandi, M., \& Sharafi, K. (2016). The effect of eliminating subsidies on food consumption of households in Kermanshah -Iran. International Journal of Pharmacy and Technology, 8(1), 11141-11150.

Pinstrup-Andersen, P. (1988). Food subsidies in developing countries: costs, benefits, and policy options. International Food Policy Research Institute (IFPRI). Washington, DC: Johns Hopkins University Press.

Pistrup-Andersen, P., \& Alderman, H. (1988). The effectiveness of consumer-oriented food subsidies in reaching rationing and income transfer goals. In P. Pistrup-Andersen (Ed.), Food 
subsidies in developing countries: costs, benefits, and policy options. Baltimore: Johns Hopkins University Press.

Ruiz-Arranz, M., Davis, B., Handa, S., Stampini, M., \& Winters, P. (2006). Program Conditionality and Food Security: The Impact of PROGRESA and PROCAMPO Transfers in Rural Mexico. Economia, 7(2), 249-278.

Sahn, D. (1987). Changes in the Living Standards of the Poor in Sri Lanka During a Period of Macroeconomic Restructuring. World Development, 16(6), 809-830.

Schanbacher, W. (2010). The Politics of Food: The Global Conflict between Food Security and Food Sovereignty. California: ABC-CLIO.

Schnepf, R. (2004). Iraq Agriculture and Food Supply: Background and Issues. Congressional Research Service (CRS), Resources, Science, and Industry Division. Washington, DC: Congressional Research Service.

Sdralevich, C., Sab, R., Zouhar, Y., \& Albertin, G. (2014). Subsidy Reform in the Middle East and North Africa: Recent Progress and Challenges Ahead. International Monetary Fund, Middle East and Central Asia Department. Washington, DC: International Monetary Fund.

Skoufias, E. (2005). PROGRESA and Its Impacts on the Welfare of Rural Households in Mexico. IFPRI Research Report No. 139. Washington, DC: International Food Policy Research Institute.

Smith, L. (1997). Price stabilization, liberalization and food security: conflicts and resolutions? Food Policy, 22(5), 379-392.

Southworth, H. M. (1945, February). The Economics of Public Measures to Subsidize Food Consumption. Journal of Farm Economics, 38-66.

Tran, V., Alkire, S., \& Klasen, S. (2015). Static and Dynamic Disparities between Monetary and Multidimensional Poverty Measurement: Evidence from Vietnam. OPHI Working Paper 97. Oxford: University of Oxford.

UN \& WB. (2003). United Nations - World Bank Joint Iraq Needs Assessment. United Nations \& World Bank.

UN. (1991). Report to the Secretary-General on Humanitarian Needs in Kuwait and Iraq in the Immediate Post-Crisis Environment. New York: United Nations. 
UN. (2010). The Millennium Development Goals Report 2010. New York: The United Nations.

United Nations Population Division. (2012). World Population Prospects: The 2012 Revision. Retrieved from http://data.un.org

USAID. (2006). Public Distribution System FAQ Sheet. Iraq: United States Agency for International Development.

Weaving, R. (1996). Agricultural adjustment and food policy reform in Mexico. OED Precis No. 117. Washington, DC: World Bank.

WFP \& GOI. (2012). Food Security, Living Conditions and Social Transfers in Iraq. United Nations Worls Food Programme and the Government of Iraq.

WFP. (2005). World Food Programme Annual Report 2004. Rome: World Food Programme.

WFP. (2006). Food Security and Vulnerability Analysis. Baghdad: World Food Programme.

WFP. (2008). Comprehensive Food Security and Vulnerability Analysis in Iraq. Baghdad: World Food Programme.

WFP. (2009). Emergency Food Security Assessment Handbook (Second Edition ed.). Rome: World Food Programme.

WFP. (2011). Cash for Change Newsletter \#1. Rome: World Food Programme.

WFP. (2013a). Purchase for Progress. Rome: World Food Programme.

WFP. (2013b). WFP And Iraq Government Aim To Introduce Electronic Food Vouchers [Press Release]. Retrieved from https://www.wfp.org/news/news-release/wfp-andgovernment-aim-introduce-electronic-food-voucher-pds

WFP. (2013c). WFP Strategic Plan (2014-2017). Rome: World Food Programme.

WFP. (2013d). WFP Strategic Results Framework (2014-2017). Rome: World Food Programme.

WFP. (2014a). Cash and Voucher Manual. Rome: The World Food Programme. Retrieved from https://www.wfp.org

WFP. (2017). WFP Strategic Plan (2017-2022). Rome: World Food Programme.

World Bank. (2007). Considering the Future of the Iraqi Public Distribution System. Washington, DC: The World Bank. 


\section{Price Opinion Data in Subsidized Economies: Empirical Evidence from Iraq}

\subsection{Introduction}

Many developing countries maintain food consumption subsidies. Although, their rationale may vary by context, these subsidy regimes are invariably described as costly, wasteful systems and are often associated with concerns of corruption and rent seeking (Adams, 2000). Motivated by the need to alleviate fiscal burden of maintaining food consumption subsidies, international financial institutions often support national governments in undertaking policy reforms aiming to eliminate the subsidy regimes through undertaking policy impact analysis that identify the distributional impacts of policy reform.

Conducting welfare analysis and assessing the distributional impact of policies is, however, often complicated by the presence of commodity rationing and consumer subsidies, particularly where prices paid by consumers do not reflect true marginal utility of consumption (Hentschel \& Lanjouw, 1996). In such contexts, virtual prices of the rationed or subsidized good should be used to value household consumption of the good rather than paid prices (Rothbarth, 1941; Neary \& Roberts, 1980; Deaton A., 1981; Lee \& Pitt, 1987).

As calculating virtual prices for subsidized goods can be computationally involved - see for example Dréze and Stern (1990) welfare analysts sometimes resort to using market price opinions, where household budget survey respondents are asked to provide their opinions of equivalent market prices of subsidized or rationed goods, in place of shadow prices. A review of household surveys on the World Bank Living Standards Measurement Study (LSMS) project website shows that one of every six LSMS surveys collects price opinion data and that two thirds of the countries where this data is collected maintained food subsidies or food rationing regimes suggesting that price opinions on equivalent market prices are often be taken to represent shadow prices. 
The body of literature on price opinion data is very sparse, with the work of Gibson and Rozelle (2002) in the context of Papua New Guinea, being the only systematic review of the performance of price opinion data. No published work has been found that examines the performance of price opinion data in the approximation of virtual prices of subsidized or rationed commodities.

Drawing on existing knowledge on money metric utility (Samuelson, 1974) and its drawbacks in welfare analysis, particularly sensitivity to heterogeneity of consumer preferences (Blackorby and Donaldson (1988); Ravallion (1998); Deaton and Zaidi (2002)), this paper addresses the gap in literature on the performance of price opinion data as shadow prices for rationed food commodities, drawing specifically on the Iraqi experience with the national food rationing regime - the Public Distribution System. Using data collected in Iraq, this paper explores the possibility that the implicit income transfer value of food acquired at subsidized prices - and varying consumer preferences across income - bias price opinions offered by survey respondents. The implications of biased price opinions on welfare analysis are also explored.

The format of the remainder of this paper is as follows. Section 2 reviews the main types of price data commonly used in welfare analysis, exploring the importance of price data in constructing welfare aggregates. Section 3 develops the analytical approach adopted in this paper and section 4 summarizes the country context, including the management and functioning of the Public Distribution System and presents the various sources of data used in the analysis.

Section 5 presents the main model results and diagnostics whereas section 6 explores the implications of utilizing price opinion data in welfare analysis. Section 7 presents the final concluding remarks. 


\subsection{Price data in the welfare analysis literature}

Data on prices of consumed commodities and services is a critical component of household and welfare measurement. While the underlying interest is the measurement of consumption, welfare analysts often rely upon consumption expenditures - aided by price data - to facilitate aggregation of the diverse units of consumption into a single welfare measure. Price data facilitates the conversion of quantities consumed into a common numeraire, or equivalently the measurement of consumed quantities from expenditures made (Hentschel and Lanjouw, 1996). As such, prices directly influence how quantities consumed translate into welfare.

The relevance of price data in current welfare analysis practices becomes apparent when referring to earlier economic theory literature, such as Houthakker's (1952) use of the indirect utility function and McKenzie's (1957) specification of the expenditure function in terms of quantitities and prices. This was further developed by Samuelson (1974), who argued that for fixed prices, the expenditure function specified by McKenzie is an exact representation of consumer preferences, which is known as money metric utility.

The conception of the consumer as a rational economic agent that seeks to maximize utility when faced with a budget constraint and a set of prevailing prices is, accordingly, the current practice in welfare analysis and is the "basic measure of welfare in market situations" (Deaton, 1980). Specifically, consumer demands for goods are represented by the cost function $c(u, p)$ representing the minimum cost of achieving utility level $(u)$ when faced with a vector of prices $(p)$. The function $c(u, p)$ is equal to total expenditure $(x)$ when the consumer maximizes utility $(u)$ by maximizing consumption of quantity vector $(q)$, constrained by the equality $x=p \cdot q$ and represents the indirect utility function of achieving utility level $(u)$ given the vector of prices $(p)$ and a budget constraint $(x)$.

This implies that estimation of money metric utility requires full information on consumer preferences - normally estimated through 
demand modeling. However, Deaton and Zaidi (2002) show that money metric utility $\left(u_{m}^{i}\right)$ can be approximated through a first-order expansion of $c\left(u, p^{r}\right)$ in prices around the vector of prices paid by the household $\left(p^{i}\right)$ such that, for the $i^{\text {th }}$ household,

$$
u_{m}^{i}=c\left(u^{i}, p^{r}\right) \approx c\left(u^{i}, p^{i}\right)+\left(p^{r}-p^{i}\right) \cdot q^{i}
$$

Accordingly, if the prices paid by the household $\left(p^{i}\right)$ are higher than the reference prices $\left(p^{r}\right)$, the value $p^{r} \cdot q^{i}$ would be less than the value $p^{i} \cdot q^{i}$, thus households expenditure is "deflated" by the value $\left(p^{r} \cdot q^{i}\right)-\left(p^{i} \cdot q^{i}\right)$. Similarly, if the prices paid by the household $\left(p^{i}\right)$ are lower than the reference prices $\left(p^{r}\right)$, households expenditure is "inflated" by the value $\left(p^{r} \cdot q^{i}\right)-\left(p^{i} \cdot q^{i}\right)$.

Since it is rare to observe a complete set of quantities for each household and - sometimes of reference prices - in practice, the Paasche price index $\left(P_{P}^{i}\right)$ is relied upon to compare the reference price vector with the vector of prices paid by the $i^{\text {th }}$ household $\left(P_{P}^{i}=p^{i}\right.$. $\left.q^{i} / p^{r} \cdot q^{i}\right)$. It follows that the money metric utility of the $i$ th household $\left(u_{m}^{i}\right)$ is approximated by:

$$
u_{m}^{i} \approx p^{i} \cdot q^{i} / P_{P}^{i}=x^{i} / P_{P}^{i}
$$

Where, $x^{i}$ is total expenditure and $P^{i}$ is the Paasche (currentweighted) price index comparing paid prices $\left(p^{i}\right)$ with reference prices $\left(p^{r}\right)$.

However, unless preferences are strictly homothetic or semihomothetic, where household preferences over bundles of goods are constant across different income groups, money metric utility is not guaranteed to be a concave function of income (Blackorby and Donaldson, 1988), thereby violating the decreasing marginal utility of 
wealth property of utility functions. Accordingly, money metric utility performs poorly in the context of assessing the distributional effects of policies (Deaton and Zaidi, 2002).

To address this drawback in welfare analysis, Blackorby and Donaldson (1987) proposed the welfare ratio as a more distributionally-sensitive measure of welfare. The welfare ratio is simply the ratio of expenditures to the level of expenditures needed to reach a minimally acceptable level of utility - i.e. the poverty line. Thus, the $i^{\text {th }}$ household (or individual) welfare ratio $\left(w r^{i}\right)$ is given by,

$$
w r^{i}=\frac{c\left(u^{i}, p^{i}\right)}{c\left(u^{z}, p^{i}\right)}
$$

Where $\left(u^{z}\right)$ is the "utility poverty line". To represent welfare ratio in monetary terms, the ratio in Equation 3 is multiplied by the poverty line valued at reference prices $\left(p^{r}\right)$, such that the transformed welfare ratio measure for the $i^{\text {th }}$ household $\left(u_{r}^{i}\right)$ is given by,

$$
u_{r}^{i}=\frac{c\left(u^{i}, p^{i}\right)}{c\left(u^{z}, p^{i}\right)} \times c\left(u^{z}, p^{r}\right)
$$

This is equivalent to normalizing expenditures by a true cost of living index, $c\left(u^{z}, p^{i}\right) / c\left(u^{z}, p^{r}\right)$ which is the poverty line valued at prices faced by the household divided by the poverty line valued at reference prices (Ravallion, 1998). In practice, the cost of living index is approximated by the Laspeyres price index $\left(P_{L}^{i}\right)$ (Deaton and Zaidi, 2002), which is calculated by,

$$
P_{L}^{i}=\sum_{k=1}^{n} w_{k}^{z r}\left(\frac{p_{k}^{i}}{p_{k}^{r}}\right)
$$


where $w_{k}^{z r}$ is the budget share at the poverty line indifference curve. Thus, similar to money metric utility, the welfare ratio expressed in monetary terms is the product of dividing expenditures by the Laspeyres price index $u_{r}^{i}=x^{i} / P_{L}^{i}$. However, while the welfare ratio provides a solution to the poor curvature properties of money metric utility, thereby allowing distributional analysis, it is also the case that the welfare ratio is an inexact indicator of welfare unless preferences are strictly homothetic - essentially distorting the welfare of households whose consumption level is far from the poverty line (Blackorby and Donaldson, 1987).

It is evident from equations $1-5$ and the surrounding discussion that obtaining accurate price data bears significant influence on the ability to accurately assess both welfare levels and the distributional impacts of policies. It is therefore understandable that welfare analysts often exert significant effort to obtain reliable price data during household budget surveys that can then be utilized to adjust nominal expenditures to produce what is commonly referred to as real consumption expenditure - the main building block of the welfare aggregate employed in welfare analysis (Deaton, 1997).

Typical approaches to acquiring price data include market surveys, direct estimation from available data in the form of unit values or respondent price opinions. Standard LSMS survey guidelines recommend the administration of a market survey in communities included in the household sample to collect market price data for a pre-determined selection of food and non-food commodities normally consumed by individuals in the country (Grosh and Glewwe, 1995). However, not all LSMS surveys actually conduct community market surveys (Frankenberg, 2000) and it is often the case that these surveys have quality problems such as price data collected from markets other than those frequented by the household survey respondents or that the list of goods in the price survey are different from those consumed by the survey respondents (Deaton and Grosh, 2000) or that markets are set up sporadically, especially in rural areas, leading to incomplete price data (Gibson and Rozelle, 2005).

In the absence of community market surveys, or when they are found to be of low quality, researchers frequently revert to using unit values 
as quasi-price measures (Deaton, 1988). Unit values are the ratio of expenditure on an acquired item to the quantity of the item acquired. The popularity of unit values among researchers can be explained by the fact that household budget surveys collect data on quantities acquired and expenditures on them and that no particular effort is required to estimate unit values.

Unit values are utilized in estimating spatial price indices that are used to deflate consumption expenditures and enable comparisons between geographic areas (Deaton, 1988). However, as Deaton and Tarozzi (2000) note, even though unit values have price-like characteristics, they are not prices and may deviate from indicators of market conditions, particularly when goods included in surveys are heterogeneous or poorly defined. Accordingly, unit values reflect the prices of a variety goods, this adding variation due to differences in the variety of consumer choices and - importantly - the quality of the acquired goods.

Other disadvantages of unit values include the fact that they typically cannot be estimated for items where quantity data is not collected or is not well defined (Deaton and Tarozzi, 2000). Moreover, unit values are available only for purchasers as opposed to market prices where the data would exist regardless of whether surveyed household procured them or not during the reference period (Gibson, 2007). Since unit values are derived from expenditure and the quantity acquired, measurement error in either factor is transmitted to the unit value (Deaton, 1997).

Reliance on unit values have been reported to lead to overestimation of poverty lines and poverty rates (Gibson and Rozelle, 2005; Capeau and Dercon, 2006). To minimize this, Deaton proposed careful graphical and analytical review of unit value data (Deaton and Tarozzi, 2000), including the replacement of household level unit values with their cluster or locality median values (Deaton and Zaidi, 2002)

In addition, Deaton $(1989 ; 1997)$ derived a method for consistent estimation of demand elasticities using unit value, even with the presence of measurement error and quality effects. With continued reliance on unit values as price measures, the method remains widely 
utilized in the applied demand measurement literature (McKelvey, 2011), despite having been the subject of some critique (See Niimi, 2005 or McKelvey, 2011).

One proposed alternative to conducting community market surveys, or the use of unit values, is asking community informants or household survey respondents to report market prices for a list of commodities regardless of whether the household acquired the commodity or not (Frankenberg, 2000), although Frankenberg suggests that this method may be unreliable, particularly considering how little is known about such price data collection methods and among concerns that such 'price opinions' would not be representative of suffer from other biases such as differences in bargaining skills and uncertainty about reference periods (Gibson and Rozelle, 2005).

Motivated to find a plausible solution to this problem, Gibson and Rozelle (2002) devised an experiment to test the merits of different sources of food price data. Through the experiment, information on price data collected through unit values and price opinions of respondents that were shown pictures of a selection of food items was compared to price data collected through a market price survey. The different price measures were used to calculate poverty lines and demand system estimates which were compared to those calculated using market prices.

Through this experiment, Gibson and Rozelle $(2002,2005)$ illustrated that price opinion data for select food items, collected with the help of visual aids, reduced quality effects and performed better as market price proxies than unit values in both poverty measurement and demand system estimation. This experiment was the "only systematic attempt" to test the reliability of price opinion data (Gibson and Rozelle, 2005) while others considering the merits of price opinion data have concluded that "further research would be necessary to recommend this method more broadly" (Gaddis, 2016)

Yet, to gain an appreciation of the extent to which price opinion data is actually relied upon, we perform a thorough review of the 
questionnaires of LSMS surveys included in the World Bank's LSMS website $^{10}$. Of the 107 LSMS surveys included in the "LSMS Data Finder" site, 102 surveys conducted in 36 countries between 1985 and 2017 were found to include expenditure data that can be used in building a consumption aggregate for use in welfare analysis. These are surveys.

The review of the questionnaires reveals that unit values and market surveys are, indeed, the two main sources of food price information for LSMS surveys. Nonetheless, one out of every six surveys was found to collect price opinion data from either household survey respondents or community key informants in a quarter of the countries (nine out of thirty-five countries). Table 1 presents the main results of the review.

\section{Table 1: Type of food price data frequently collected in LSMS surveys}

\begin{tabular}{lcc} 
& Proportion & Number \\
\cline { 2 - 3 } Price Data from Community Market Survey & $62.7 \%$ & 64 \\
Unit Values - Purchased Food & $69.6 \%$ & 71 \\
Unit Values - Own Produced food & $39.2 \%$ & 49 \\
Unit Values - Other food sources & $30.4 \%$ & 31 \\
Price Opinion & $17.6 \%$ & 18 \\
\hline
\end{tabular}

Source: Authors calculation from a review of all questionnaires in the World Bank's “LSMS Data Finder” site

Interestingly, most of the countries ${ }^{11}$ (six of the nine countries) that collected price opinion data either maintained or were in the process for reforming food subsidy or rationing regimes - implying preference for price opinion data in contexts where regulations distort market prices.

\footnotetext{
${ }^{10}$ http://iresearch.worldbank.org/Isms/IsmssurveyFinder.htm

${ }^{11}$ Albania, Bulgaria, China, Ecuador, Ghana and Iraq
} 
This, it appears, is not without reason. In a World Bank Living Standards Measurement Study (LSMS) Working Paper, Jesko Hentschel and Peter Lanjouw (1996) stress that, under a system of rationing, prices paid by households for rationed goods do not represent the true marginal utility from consumption of these goods as prices are artificially kept from rising despite the restrictions on quantities. Accordingly, shadow prices should be used to value consumption of rationed goods instead of paid prices.

Following this recommendation, for example, the World Bank and the Iraqi Central Statistical Organization sought to value rationed food items received through the Public Distribution System at market prices using price opinion data rather than valuing the food items at paid official prices (Amendola and Vecchi, 2011).

\subsection{Analytical Approach and Model Specification}

The difference between paid prices for rationed goods and open market prices for the same goods, coupled with the ability of consumers to acquire the rationed good through both the Public Distribution System and commercially at market prices introduces significant complications to the process of constructing welfare indicators.

In the context of consumer subsidies and rationing, the difference between paid prices and market prices for subsidized commodities represents - quite literally - the value of income transferred to the household by virtue of the subsidy. A number of studies conducted within the similar context of the Public Distribution System in India (see Kaul, 2014; GSI, 2010; Kochar, 2005 and George, 1979) have defined the value of subsidy, or the $\mathrm{i}^{\text {th }}$ household's subsidy income transfer value from acquiring the $\mathrm{k}^{\text {th }}$ commodity $\left(V_{i}^{k}\right)$ as:

$$
V_{i}^{k}=\left(p_{r}^{k}-p_{i}^{k}\right) \cdot q_{i}^{k}
$$


Where:

$V_{i}^{k}$ is the value of transfer income for the $\mathrm{i}^{\text {th }}$ household from the $\mathrm{k}^{\text {th }}$ subsidized food commodity,

$p_{r}^{k}$ is the reference market price of the $\mathrm{k}^{\text {th }}$ food commodity,

$p_{i}^{k}$ is the official prices paid by the $\mathrm{i}^{\text {th }}$ household for the $\mathrm{k}^{\text {th }}$ rationed food commodity,

$q_{i}^{k}$ is the quantity acquired by the $\mathrm{i}^{\text {th }}$ household of the $\mathrm{k}^{\text {th }}$ food commodity included in the PDS food basket.

In the Iraqi context, where information on reference market prices for a rationed commodity is retrieved through requesting respondent opinions on the market value of the rationed goods, Equation 6 is modified to replace reference market prices $\left(p_{r}^{k}\right)$ with the respondent's price opinion $\left(p o_{i}^{k}\right)$ such that $V_{i}^{k}=\left(p o_{i}^{k}-p_{i}^{k}\right) \cdot q_{i}^{k}$. In other words, the subsidy income transfer received by a household is a function of the actual prices they face - i.e. paid prices - and their perception of the market value of subsidized goods - i.e. price opinion.

Literature from the marketing and product pricing fields often distinguishes between objective prices and perceived prices. Consumer's awareness of prices is reported to be influenced by demographic factors such as gender, marital status, age and employment (Zeithaml, 1988) as well as by commodity specific attributes such as durability, and by price dispersion for the same good in the market (Maynes and Assum, 1982).

Since price opinions are - in effect - price perceptions, they may be influenced by demographic factors and by the ease of acquisition of the commodities in question. In the context of food consumption subsidies or food rationing systems such as that in Iraq, it is possible that influences, such as the relevance of the implicit transfer to the overall household budget, may introduce bias in the valuation of the quantities acquired from the PDS.

The existing literature on sources of reporting error in household budget surveys is narrowly focused on issues such as recall versus diary taking, level of aggregation in the commodity list and length of reference period. A number of studies have established that greater 
cognitive demand is placed on respondents in instances where the recall period is too long or when respondents are requested to respond to hypothetical questions such as average expenditures or consumption during 'typical' months - leading to biased estimates caused by reporting error (Beegle et al, 2010). In the study conducted by Beegle et al., the effects of the extent of cognitive demand on survey respondents due to various data collection methods as well as household characteristics were tested using multiple regression models.

A prerequisite for regression analysis is ascertaining the presence of sufficient variation in the price data. Table 2 lists mean prices and dispersion ratios for five commodities distributed through the PDS from price information collected through market surveys and respondent price opinions for the same commodities. The dispersion ratios reveal significant price variation for all items. Commodities with the least variation have a dispersion ratio of 2 - meaning the highest recorded price is twice that of the lowest price.

\section{Table 2: Comparing market prices and price opinion data for rationed items}

\begin{tabular}{lccccc} 
& \multicolumn{2}{c}{ Market Prices } & & \multicolumn{2}{c}{ Price Opinion } \\
\cline { 2 - 3 } \cline { 5 - 6 } & $\begin{array}{c}\text { Mean } \\
\text { IIraqi } \\
\text { Dinars) }\end{array}$ & Dispersion & & $\begin{array}{c}\text { Mean } \\
\text { (Iraqi } \\
\text { Dinars) }\end{array}$ & Dispersion* \\
\cline { 2 - 3 } \cline { 5 - 6 } Brown Wheat & 493 & 2.7 & & 459 & 2.5 \\
Flour & 1,290 & 5.8 & & 474 & 3.8 \\
Rice & 1,337 & 2.1 & & 1,355 & 3.0 \\
Sugar & 2,187 & 2.0 & & 2,170 & 2.5 \\
Vegetable Oil & 2,241 & 2.0 & & 1,792 & 2.0 \\
Vegetable Fat & & & & & \\
\hline
\end{tabular}

Sources: Market prices - Average of 2011-Q1 market price bulletin; Price opinion Authors calculation using 2011 IKN survey data.

${ }^{*} 99^{\text {th }}$ percentile divided by the $1^{\text {st }}$ percentile

Remembering that the price opinion data for the subsidized PDS commodities serves as a proxy for their shadow prices. These prices therefore should reflect the marginal utility from the consumption of these goods. It follows, therefore, that the comparison of the price 
opinions for PDS goods and the market prices for their commercial equivalents (Table 2) provides insight into the respondents' preferences over these goods. For example, that the price opinion for PDS wheat flour being slightly lower than the market price of its commercial equivalent can be taken to indicate that respondents consider their PDS wheat flour ration to be extra marginal. This is also true for vegetable fat and oil, and for rice to a far greater extent to a greater extent. The opposite can be said for PDS sugar, which is valued at higher than prevailing market prices. However, this comparison would hold only if little differences exist in the quality of the goods, a proposition that could not be explored with the data at hand.

Poor infrastructure, high levels of violence and barriers to free movement between the different areas of Iraq led to poor market linkages and explains the presence of high spatial variation in market prices. Spatial variation in prices is not only present in the commodities listed in table 2 and spans across a wider range of goods. For example, the Consumer Price Index for Diyala - a district only 50 kilometers north east of Baghdad - is 40 percent higher than the CPI for Baghdad during the first quarter of $2011^{12}$. The extent of spatial variation in price opinion data is highlighted in table 3 .

${ }^{12}$ Authors calculations from the January through March CPI reports in 2011 (CSO, 2011) 
Table 3: Spatial variation across Governorates in price opinion data for rationed items

\begin{tabular}{|c|c|c|c|c|c|}
\hline & \multicolumn{5}{|c|}{ Price Opinion (Iraqi Dinar/ Kg) } \\
\hline & Rice & $\begin{array}{l}\text { Wheat } \\
\text { Flour }\end{array}$ & $\begin{array}{c}\text { Vegetable } \\
\text { Fat }\end{array}$ & $\begin{array}{c}\text { Vegetable } \\
\text { Oil }\end{array}$ & Sugar \\
\hline Dohuk & 690 & 356 & 1634 & 2183 & 1127 \\
\hline Mosul & 500 & 478 & 1737 & 2281 & 1437 \\
\hline Sulaimaniya & 348 & 377 & 1543 & 1898 & 1347 \\
\hline Kirkuk & 499 & 500 & --- & 2250 & --- \\
\hline Erbil & 286 & 291 & 1526 & 2243 & 1345 \\
\hline Diyala & 493 & 495 & 1845 & 2397 & 1375 \\
\hline Anbar & 493 & 482 & 1791 & 2282 & 1160 \\
\hline Baghdad & 488 & 488 & 1936 & 2370 & 1258 \\
\hline Babylon & 499 & 495 & 1828 & 2256 & 1395 \\
\hline Kerbala & 447 & 485 & 1845 & 2285 & 1426 \\
\hline Wassit & 499 & 479 & 1660 & 2304 & 1373 \\
\hline Salah Al Din & 498 & 498 & 1898 & 1864 & 1430 \\
\hline Najaf & 454 & 464 & 1627 & 2344 & 1337 \\
\hline Qadisiya & 500 & 499 & 1890 & 2473 & 1424 \\
\hline Muthanna & 499 & 499 & 1996 & 2160 & 1255 \\
\hline Thi-Qar & 499 & 499 & 1702 & 2500 & 1284 \\
\hline Maysan & 499 & 500 & 1861 & 2368 & 1495 \\
\hline Basrah & 496 & 492 & 1781 & 2347 & 1374 \\
\hline $\begin{array}{l}\text { Dispersion } \\
\text { (high/low) }\end{array}$ & 2.4 & 1.7 & 1.3 & 1.3 & 1.3 \\
\hline
\end{tabular}

Source: Authors calculation using 2011 IKN survey data.

\section{Model Specification}

Given the structure of the data where the available market price data is collected at the sub-district level for the monthly consumer price index series, a multilevel modelling approach is required. Accordingly, the reference market price data is constant within the sub-district and only varies between districts. Such an approach 
models households to be nested within markets and all households within the same sub-district face the same prevailing market prices.

A log-log hierarchical linear model fitted for each of the five rationed items, with households nested within sub districts, would allow the observation of any statistically significant association between the income transfer value of the food subsidy and household specific socio economic and demographic indicators while holding constant local market prices. The log-log specification is followed in order to transform log-normally distributed variables to follow a normal distribution as well as to allow the interpretation of coefficients as percent deviations.

The choice of the hierarchical model specification is motivated by the fact that the market price data is constant within sub districts and varies only between sub districts. Moreover, the choice of the hierarchical model specification, where households are nested within markets, allows the analysis of the variance in the value of subsidy $\left(V_{k}^{i}\right)$ due to local market conditions separately from the variance due to household level conditions.

With the dependent variable as the transfer value of the subsidy $\left(V_{k}^{i}\right)$ from the $\mathrm{k}^{\text {th }}$ food commodity for the $\mathrm{i}^{\text {th }}$ household in the $\mathrm{j}^{\text {th }}$ sub district, the generic hierarchical model would be specified as:

$$
\begin{aligned}
\ln \left(V_{i j}^{k}\right)= & \gamma_{00}+\gamma_{01} \ln \overline{p_{J}^{k}}+\gamma_{10} \ln \left(y_{i j}\right)+\gamma_{20} \ln \left(q_{i j}^{k}\right)+ \\
& \gamma_{30} \ln \left(q_{i j}^{k}\right)^{2}+\gamma_{40} z_{i j}^{k}+\sum_{1}^{n} \gamma_{50}^{n 0} \zeta_{i j}+u_{j}^{k}+\varepsilon_{i j}^{k}
\end{aligned}
$$

Where,

$V_{i j}^{k}$ is the transfer value from the $\mathrm{k}^{\text {th }}$ subsidized commodity received by the $\mathrm{i}^{\text {th }}$ household in the $\mathrm{j}^{\text {th }}$ sub-district;

$p_{j}^{k}$ is the mean market price of commodity $k$ in the $j^{\text {th }}$ sub-district;

$q_{i j}^{k}$ is the quantity of the kth rationed commodity acquired through the PDS, and $q_{i j}^{k^{2}}$ is its quadratic term; 
$y_{i j}$ is total per capita consumption expenditures for the $i^{\text {th }}$ household in the jth sub-district;

$z_{i j}^{k}$ is a binary variable indicating whether the household has purchased the rationed commodity from the market during the 7 day period of the diary; and

$\zeta_{i j}$ is a vector of household demographic variables including household size and the age and sex of the head of household.

The subscript notation in Eq. 7 follows the typical mixed model notation where $\left(\gamma_{\mathbf{n} 0}\right)$ represents the coefficient for the $\mathrm{n}^{\text {th }}$ independent variable in the household level model (level 1) and where $\left(\gamma_{0 n}\right)$ represents the coefficient for the $\mathrm{n}^{\text {th }}$ independent variable in the level 2 model.

Building on the equality presented in Eq. 6, the specification in Eq. 7 would model the value of the subsidy to the household $\left(V_{i j}^{k}\right)$ from the $\mathrm{k}^{\text {th }}$ subsidized commodity received by the $\mathrm{i}^{\text {th }}$ household in the $\mathrm{j}^{\text {th }}$ subdistrict as a function of the quantity of the subsidized commodity acquired by the household $\left(q_{i j}^{k}\right)$ and market prices $\left(p_{j}^{k}\right)$ of equivalent commodities $^{13}$. From Eq. 6, it is apparent that the coefficients for the $q_{i j}^{k}$ and $p_{j}^{k}$ should be significant and positive. In other words, the value of the subsidy to a household is expected to be higher with greater quantities and higher market prices.

The remaining independent variables in Eq. 7 are included to explicitly test for potential sources of biases in the price opinion data. Gibson and Rozelle (2005) contend that significant covariance with observable household characteristics $\left(\boldsymbol{\zeta}_{\boldsymbol{i}}\right)$ would suggest the presence of bias due to differences in bargaining skills or the sort of quality and variety bias that are typically associated with unit values. If, after controlling for market prices and quantities acquired, the coefficient for per capita expenditure $\left(y_{i j}\right)$ is significant, it can be concluded that

${ }^{13}$ This is equivalent to the reference prices $\left(p_{k}^{r}\right)$ specified in Eq. 6. 
the underlying price opinion data is influenced by the respondent's perception of the value of the transfer within the household budget. In addition, the coefficient for the binary variable $\left(z_{i j}^{k}\right)$, which indicates whether the household had actually purchased from the market a quantity of the same subsidized commodity during the 7 day period of the diary is included to control for the possibility that respondents that have not recently purchased the commodity in the market may not know enough about either prices or the quality of the rationed commodity to provide reliable information.

However, it is also apparent that the model specified in Eq. 7 may suffer from endogeneity. Specifically, it is likely that the quantity of acquired subsidized goods $\left(q_{i j}^{k}\right)$ and the value of the subsidy to the household $\left(V_{i j}^{k}\right)$ are jointly determined. Such simultaneity in the model can lead to significant correlation between the error term $\left(\varepsilon_{i j}^{k}\right)$ and quantity $\left(q_{i j}^{k}\right)$, thus biasing the estimated coefficients.

A typical solution for this would be to apply instrumental variable regression techniques. However, instrumental variables that are simultaneously strongly correlated with the endogenous independent variable and uncorrelated with the model error term are famously difficult to find (Crown et al., 2011) while simply opting to exclude the endogenous variable would lead to omitted variable bias.

To address this concern, we opt to estimate the model as a generalized structural equation where the model for the value of the subsidy to the household $\left(V_{i j}^{k}\right)$ is simultaneously estimated alongside a second model for the quantity of the subsidized commodity acquired by the household $\left(q_{i j}^{k}\right)$. While the use of structural equation modeling remains somewhat uncommon in the economic literature, it is increasingly used in the food security literature (for example, Mohamed et al. (2017) or Deny et al., (2017)). Estimation of instrumental variable models, such as 2 Stage Least Squares (2SLS) or Latent Instrumental Variable, is also rather common in the structural equation modeling literature (for example, Hermida (2015) or Hueter (2016)). The flexibility of structural equation modeling makes it a natural choice for estimation of multilevel models (Kline, 
2011). The system of equations estimated in this paper is illustrated in the diagram below.

\section{Figure 1: Generalized Structural Equation Model Diagram}

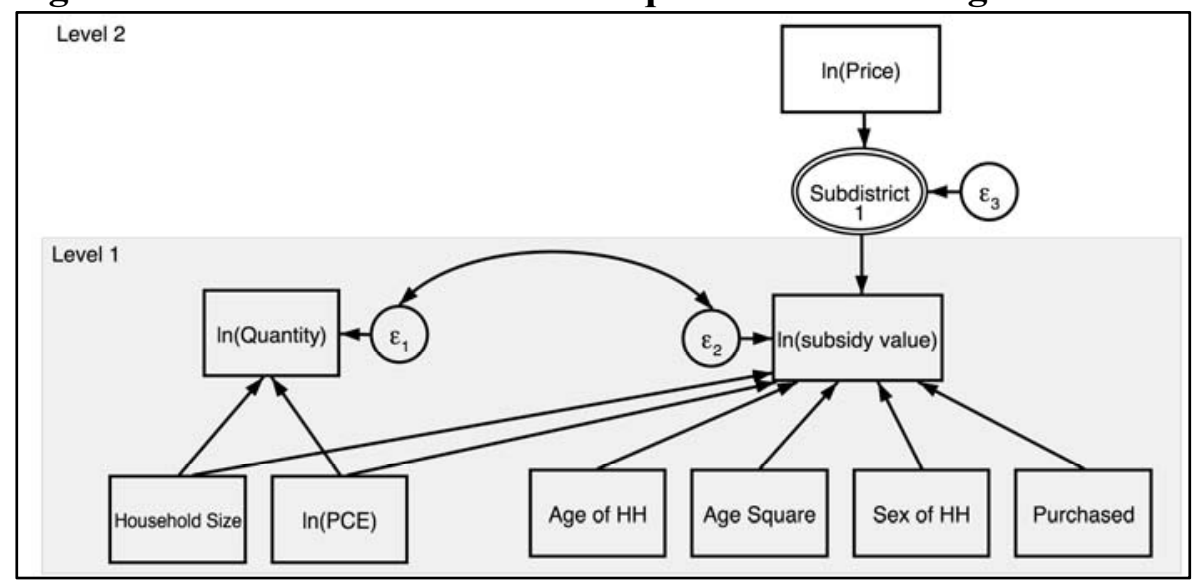

From the diagram it is apparent that the model for the value of the subsidy $\left(V_{i j}^{k}\right)$ is identical to that specified in Eq. 7 with the exception of the quantity variable $\left(q_{i j}^{k}\right)$ and its quadratic term, which are now excluded. Omitted variable bias due to the exclusion of $\left(q_{i j}^{k}\right)$ is addressed by explicitly modelling the covariance of the error terms of both endogenous variables, represented by the curved double headed path between $\varepsilon_{1}$ and $\varepsilon_{2}$. Inclusion of covariance in the error terms is a common treatment applied in structural equation modeling when both endogenous variables share a common omitted cause (Kline, 2012). Since this is the assessed case for quantity and subsidy value, the above represents a suitable approach to address potential endogeneity.

The double oval for the sub-district variable included in the diagram represents a multilevel component of the model. This is a feature of the generalized structural equation model function in $\mathrm{Stata}^{14}$, which is

\footnotetext{
${ }^{14}$ Stata 13.1 is used to estimate the model. Although it is the flexibility of the generalized structural equation model (gsem) functions within Stata that enables
} 
the program used in the present estimation. The double oval indicates that sub-district is a latent multilevel variable whose hierarchical structure is defined by the sub-district variable in the data and market price data, which is constant within sub-districts, is the single predictor of this latent multilevel variable. Accordingly, this allows the estimation of the desired random intercept multilevel model. The shaded area in the diagram represents the household level components (level 1), while the non-shaded area of the diagram represents the sub-district level component (level 2). The model is specified as

$$
\begin{aligned}
& \ln \left(V_{i j}^{k}\right)=\gamma_{00}+\gamma_{01} X^{k}+\gamma_{10} \ln \left(y_{i j}\right)+\gamma_{10} z_{i j}^{k} \\
& +\sum_{1}^{n} \gamma_{30}^{n 0} \zeta_{i j}+\varepsilon_{i j}^{k} \\
& X^{k}=\beta_{01} \ln \left(p_{j}^{k}\right)+u_{j}^{k} \\
& \ln \left(q^{k i}\right)=v_{0}^{k}+v_{1}^{k} \ln \left(y_{i}\right)+v_{2}^{k} s_{i}+e_{i}^{k}
\end{aligned}
$$

which follows the approach and notation specified in Eq. 7, though with the inclusion of the latent multilevel variable $\left(X^{k}\right)$, which is simultaneously estimated in Eq. 9 as a function of sub-district level market prices. In addition, Eq. 10 models the quantity of $\mathrm{k}^{\text {th }}$ subsidized good acquired by the $\mathrm{i}^{\text {th }}$ household as a function of total per capita consumption expenditures $y_{i}$ and total household size for the $\mathrm{i}^{\text {th }}$ household. The estimation of the system of equations is subject to the constraint that the covariance of the error terms from Eqs. 8 and 9 and from Eqs. 9 and 10 is equal to zero $\left(\sigma_{\varepsilon_{i j}^{k}, u_{j}^{k}}=\sigma_{u_{j}^{k}, e_{i}^{k}}=0\right)$, and no such restriction is placed on the covariance of the error terms from Eqs. 8 and 10 so as to minimize omitted variable bias in Eq. 8 as discussed earlier.

this estimation, this comes at a cost. The gsem function does not include goodness of fit estimates such as those found in the regular structural equation model function. It also does not allow the use of sample weights. 


\subsection{Country Context and Data Sources}

The Iraqi Public Distribution System (PDS) is a food rationing system that was established by the Government of Iraq in 1990 as a response to the crippling sanctions facing the country following the Iraqi invasion of Kuwait. Under the PDS, all residents of Iraq are entitled to a rationed monthly basket including food and non food items. The initial design of the food basket was altered in 1998 with the establishment of the Oil For Food Programme (OFFP) managed by the United Nations where the monthly food package for each adult individual included wheat flour (9 kilos), rice (3 kilos), sugar (2 kilos), tea (200 grams), vegetable oil (1.25 kilo), pulses (250 grams) and adult milk ( 250 grams). Infants under the age of 2 years received infant formula (1.8 kilo). The non food package included detergent (500 grams) and soap (250 grams) per person per month.

In 2010, the Government of Iraq decided to reduce the items distributed through the PDS down to 5 basic items including wheat flour, rice, sugar, vegetable oil or fat and infant formula for infants only (GOI, 2009). The same Government decree also stipulated the introduction of targeting - whereby households with income higher than 1.5 million Iraqi Dinars would be excluded from the PDS system. However, in practice, this step was never fully implemented as only 60,000 public sector employee families were removed from the PDS - approximately $1 \%$ of Iraqi households.

The supply chain of the PDS is managed by the Ministry of Trade whereas distribution of the food items to the general public is administered by a network of (approximately) 50,000 food and flour agents distributed throughout Iraq. Each family receives annually from the Ministry of Trade a paper coupon indicating the name of eligible individuals and their monthly package which can only be redeemed from a specific food/flour agent. To receive the entitled quantities, recipients pay the PDS agents the subsidized, official price. These are listed below in table 4 . 
Table 4: Official Rationed Prices and Open Market Prices for PDS commodities

\begin{tabular}{lcc} 
& $\begin{array}{c}\text { Official Price } \\
\text { (Iraqi Dinars) }\end{array}$ & $\begin{array}{c}\text { Market Price } \\
\text { (Iraqi Dinars) }\end{array}$ \\
\cline { 2 - 3 } Brown Wheat Flour $(1 \mathrm{~kg})$ & 6 & 493 \\
Rice $(1 \mathrm{~kg})$ & 10 & 1,290 \\
Sugar $(1 \mathrm{~kg})$ & 12 & 1,337 \\
Vegetable Oil (1 ltr) & 6 & 2,187 \\
Vegetable Fat $(1 \mathrm{~kg})$ & 6 & 2,241 \\
\hline
\end{tabular}

Source: Average of 2011-Q1 market price bulletin.

Considering the official ration size, the average Iraqi above the age of 2 years should pay 114 ID monthly to receive a food package, the value of which is 13,207 ID. Families with infants pay 208 ID monthly for infant formula valued at 24,116 ID per infant. That is to say that the market value of the rationed commodities is approximately 115 times the official price.

Equivalent food commodities as those received through the PDS are also available on the Iraqi markets. Households are free to purchase any quantity of these food items from the market at normal market prices.

Moreover, as wealthier Iraqi households seeking higher quality commercial food commodities often sell their rationed food items to their PDS agents, the rationed food items are also frequently found on the market. Therefore, while officially a rationing system, the PDS imposes no effective limits on quantities acquired outside of the rationed food basket as no restrictions exist on the private sector to trade the same food commodities. Iraqis frequently purchase equivalent food items from the commercial food retail sector at prices set by market forces rather than officially set prices. Considering the lack of effective rationing of consumption, the PDS is best described as a consumer subsidy.

Inefficiencies in the PDS supply chain further undermine its role as a rationing tool. As shown in table 5, only a small proportion of 
households actually are able to acquire their sugar and vegetable oil/fat rations. The responsibilities for the procurement and distribution of the commodities in the PDS ration are divided between two state owned companies. The State Company for Grain Trade, responsible for the procurement and distribution of wheat flour and rice, manages a more efficient supply chain than the State Company for Food Stuff Trade, which is responsible for the sugar and vegetable oil/fat supply chains. Accordingly, Iraqi households often procure their basic food commodities, including those within their PDS ration, in the market.

Table 5: Percent of Households acquiring their PDS ration items by item and month

\begin{tabular}{|c|c|c|c|c|c|c|c|}
\hline & $\begin{array}{c}\text { Jul- } \\
2010 \\
\end{array}$ & $\begin{array}{l}\text { Aug- } \\
2010\end{array}$ & $\begin{array}{l}\text { Sep- } \\
2010\end{array}$ & $\begin{array}{c}\text { Oct- } \\
2010 \\
\end{array}$ & $\begin{array}{l}\text { Nov- } \\
2010 \\
\end{array}$ & $\begin{array}{l}\text { Dec- } \\
2010 \\
\end{array}$ & $\begin{array}{c}\text { Jan- } \\
2011 \\
\end{array}$ \\
\hline $\begin{array}{l}\text { Wheat } \\
\text { Flour }\end{array}$ & $71.7 \%$ & $75.1 \%$ & $75.7 \%$ & $75.7 \%$ & $71.4 \%$ & $66.4 \%$ & $62.2 \%$ \\
\hline Rice & $61.2 \%$ & $66.0 \%$ & $67.0 \%$ & $67.0 \%$ & $64.1 \%$ & $62.1 \%$ & $62.7 \%$ \\
\hline Sugar & $4.7 \%$ & $11.0 \%$ & $8.1 \%$ & $4.8 \%$ & $2.4 \%$ & $1.5 \%$ & $2.4 \%$ \\
\hline Oil & $21.4 \%$ & $28.0 \%$ & $27.4 \%$ & $25.3 \%$ & $21.9 \%$ & $17.0 \%$ & $14.6 \%$ \\
\hline Fat & $6.4 \%$ & $7.0 \%$ & $7.6 \%$ & $8.4 \%$ & $10.4 \%$ & $15.6 \%$ & $20.0 \%$ \\
\hline
\end{tabular}

Source: IKN Tabulation Report (IKN 2011)

\section{Data Sources}

Two main sources of data are utilized in the analysis. Micro data on household consumption expenditures - including actual expenditures and quantity of acquired food and non food items - is provided through a survey on a representative sample during the first quarter of 2011. Data on market prices are also utilized.

The survey, called the Iraq Knowledge Network (IKN) survey was administered by the Iraqi Central Statistical Organization (CSO) to approximately 30,000 households distributed in all districts of Iraq and provides detailed information on the quantity of food acquired during a 7 day period and registered in a household diary maintained by the household. Information on detailed non-food expenditures 
during variable periods ranging from 1 month for recurrent non-food expenditures up to 12 months on education and durable goods are collected during the first household visit.

The data collectors visited each household a total of 3 times where the basic questionnaire was administered in the first visit and the method to fill the diary was explained to the household. The second visit occurred 3 days after the first household visit and the progress in filling the diary is reviewed. During the second visit, quantities of food received from the PDS were recorded and respondents provided price opinion data on a list of commodities normally received through the PDS. The third visit occured 8 days after the first household visit and included a revision of the diary for the whole 7-day reference period and the diary is then taken from the household and sent for quality check and data entry.

Data from the 2007 Iraq Household Socio Economic Survey (IHSES) is also utilized in this study. The survey sample consists of 17,822 households distributed over the course of 12 months of the year. The expenditure diary and PDS questionnaires from the IHSES survey are virtually the same as those from the IKN 2011 survey.

The main types of food price data used in this paper include: (a) market prices represent prevailing prices for food commodities at commercial retail outlets. This data is collected through a monthly survey of a sample of retail outlets for the purpose of updating Consumer Price Index estimates; (b) food price opinions are estimates of equivalent market prices of the subsidized, rationed food commodities included in the Public Distribution System; (c) official prices represent the nominal prices for the rationed food commodities included in the Public Distribution System as set by the Government of Iraq, and are invariant across regions and households, and (d) paid prices represent unit values for all rationed and non-rationed food commodities. For rationed food items, paid prices represent effective subsidized prices and are a reflection of official prices set by the Government but may differ from official prices in instances where additional transaction costs are added by the PDS agents.

The Iraqi Central Statistical Organization (CSO) relies upon both unit values and price opinions in the calculation of the welfare aggregate - 
real consumption expenditure - utilized in measuring the welfare of Iraqi households. In the context of Iraq, price opinions are utilized to approximate free market prices of the rationed PDS food commodities and unit values are utilized for all non-rationed goods and services.

In the 2011 IKN 2007 IHSES surveys, respondents are requested to provide an estimate of the price of a unit of the received food item, either a kilogram or liter, in the local market. The respondent is specifically requested to provide the market price of a commodity of equal quality to that received through the PDS. The relevant portion of the questionnaire is included in Appendix 2A.

A couple of concerns with the questionnaire design arise when accounting for the acquisition of the PDS food items: The first being that the reference period for the acquisition of the PDS food commodities is for 30 days, whereas the diary, which covers a period of 7 days, includes all other commodities purchased from the market on a regular basis. The second concern is that actual paid prices for the PDS commodities are not specified per item. Instead, total expenditures for the acquisition of the available commodities within the PDS food basket are grouped, preventing the direct calculation of unit values. The standard practice applied by the Iraqi Central Statistical Organization to impute paid prices for each PDS commodity is to estimate the proportional difference between the actual paid amount for the package received and the expected amount under official prices. This proportion is then used to inflate or deflate the estimated paid prices for each commodity. This imputation is also applied to the data used in the analysis performed for this paper.

Data on market prices for 446 food and non-food items collected monthly from urban centers for the purpose of updating the national and regional Consumer Price Index (CPI) is provided by the Iraqi CSO. The data is collected from 38 sub districts; 2 from each governorate, where each governorate capital is included as well as the second most populous sub district. Accordingly, the data originates from markets servicing approximately 67 percent of the Iraq population in the base year of 2007. Although the IKN micro data set is collected from all districts in Iraq and covers both urban and rural 
populations, the data utilized in fitting the estimation models originates only from households within the 38 sub districts included in the market price survey sample. The IKN sample from these sub districts is 3,785 households.

For the purpose of this analysis, market price data was utilized for the following items: local brown wheat flour, Thai rice, Brazilian sugar, Turkish and U.A.E vegetable fat, Turkish and U.A.E vegetable oil and French infant formula. The items were selected for their comparability to the commodities rationed through the PDS.

Special attention is necessary when utilizing the consumer price indices produced by the Iraqi CSO given the unique approach adopted in dealing with the PDS rationed food items. The food price index in Iraq is based upon the Laspeyres formula with commodity weights estimated using unit values for all food items, except the rationed food items, which are valued using price opinion data. However, official prices are used in producing relative price growth per PDS commodity. Accordingly, the CSO applies price opinion data to estimate the commodity weights and official prices to estimate relative price growth per commodity, which is an inconsistent use of price data.

Moreover, given the changes in the PDS system occurring in 2010 namely the reduction of the PDS food basket - and the resultant changes in consumption patterns, it is expected that the Laspeyres price index which relies on base year commodity weights would over estimate inflation during the period in question as it does not account for substitutions made by consumers.

To address these concerns, two new food price indices are calculated and used in this paper. First, a price index using official prices for rationed food items to measure item weights is calculated based upon the Fisher price index formula, which accounts for substitution of goods. The second price index is the same, though calculated using price opinion data for rationed food items to measure item weights. The market price data for 2007 and 2011 for the included food items is provided by the Iraqi CSO. Official prices are equal to those listed 
in table 4. The final price indices valued with both paid prices and price opinion data are presented in table 6 below.

Table 6: Food Price Indices with official prices and price opinions for Q1-2011 (2007=100)

Laspeyres Index

Official Price Weights

Price Opinion Weights

Paasche Index

140.97

134.86

129.01

126.31

Fisher Index

134.86

130.51

Source: Authors calculations

\subsection{Model Results and Diagnosis}

Five multilevel models estimating fixed effects allowing random slopes are fitted - one for each of the following rationed food items: Wheat Flour, Rice, Vegetable Oil, Vegetable Fat and Sugar. The generalized structural equation models followed the specification set out in Eqs. 8 through 10, with the main hypothesis being that for Price Opinion data to be considered as unbiased reflections of market prices, the parameter estimates for market prices and quantities acquired on the value of subsidy $\left(V_{i}^{j}\right)$ should be significant and positive while other significant parameters would be considered sources of bias. Table 7 presents the relevant parameter estimates with the full list of results included in Appendix 2B. 
Table 7: Estimated parameters for the value of subsidy from wheat flour, rice, vegetable oil, vegetable fat and sugar (2011)

\begin{tabular}{|c|c|c|c|c|c|}
\hline & Rice & $\begin{array}{l}\text { Wheat } \\
\text { Flour }\end{array}$ & Veg. Oil & Veg. Fat & Sugar \\
\hline Intercept, $\left(\gamma_{00}\right)$ & $\begin{array}{c}2.423 \\
(1.655)\end{array}$ & $\begin{array}{l}-3.601^{* *} \\
(1.408)\end{array}$ & $\begin{array}{l}1.600 \\
(1.762)\end{array}$ & $\begin{array}{c}0.721 \\
(1.012)\end{array}$ & $\begin{array}{c}2.673 \\
(2.115)\end{array}$ \\
\hline $\operatorname{Ln}($ Price $),\left(\beta_{01}\right)$ & $\begin{array}{l}-0.284 \\
(0.229)\end{array}$ & $\begin{array}{l}0.759^{* * *} \\
(0.200)\end{array}$ & $\begin{array}{l}-0.117 \\
(0.227)\end{array}$ & $\begin{array}{c}0.056 \\
(0.135)\end{array}$ & $\begin{array}{l}-0.234 \\
(0.284)\end{array}$ \\
\hline $\operatorname{Ln}($ Expenditure $),\left(\gamma_{10}\right)$ & $\begin{array}{l}-0.046^{* *} \\
(0.020)\end{array}$ & $\begin{array}{c}-0.059^{* * *} \\
(0.016)\end{array}$ & $\begin{array}{l}-0.024 \\
(0.017)\end{array}$ & $\begin{array}{c}-0.083^{* *} \\
(0.028)\end{array}$ & $\begin{array}{c}-0.032^{* *} \\
(0.013)\end{array}$ \\
\hline household size, $\left(\gamma_{30}\right)$ & $\begin{array}{l}0.140^{* * *} \\
(0.008)\end{array}$ & $\begin{array}{l}0.133^{* * *} \\
(0.006)\end{array}$ & $\begin{array}{l}0.153^{* * *} \\
(0.020)\end{array}$ & $\begin{array}{l}0.115^{* * *} \\
(0.010)\end{array}$ & $\begin{array}{l}0.155^{* * *} \\
(0.009)\end{array}$ \\
\hline $\begin{array}{l}\text { Sex of Household } \\
\text { head, }\left(\gamma_{40}\right)\end{array}$ & $\begin{array}{c}0.018 \\
(0.023)\end{array}$ & $\begin{array}{c}0.015 \\
(0.010)\end{array}$ & $\begin{array}{c}0.025 \\
(0.016)\end{array}$ & $\begin{array}{c}0.007 \\
(0.022)\end{array}$ & $\begin{array}{c}0.006 \\
(0.029)\end{array}$ \\
\hline $\begin{array}{l}\text { Age of Household } \\
\text { head, }\left(\gamma_{50}\right)\end{array}$ & $\begin{array}{l}-0.000 \\
(0.002)\end{array}$ & $\begin{array}{c}0.003 \\
(0.002)\end{array}$ & $\begin{array}{l}-0.003 \\
(0.003)\end{array}$ & $\begin{array}{c}0.001 \\
(0.002)\end{array}$ & $\begin{array}{c}-0.005^{* * *} \\
(0.002)\end{array}$ \\
\hline $\begin{array}{l}\text { Age of Household } \\
\text { head squared, }\left(\gamma_{60}\right)\end{array}$ & $\begin{array}{c}0.000 \\
(0.000)\end{array}$ & $\begin{array}{c}0.000 \\
(0.000)\end{array}$ & $\begin{array}{c}0.000 \\
(0.000)\end{array}$ & $\begin{array}{c}0.000 \\
(0.000)\end{array}$ & $\begin{array}{c}0.000 * * \\
(0.000)\end{array}$ \\
\hline Purchased, $\left(\gamma_{20}\right)$ & $\begin{array}{l}-0.023 \\
(0.023)\end{array}$ & $\begin{array}{l}-0.020 \\
(0.024)\end{array}$ & $\begin{array}{l}-0.123 \\
(0.129)\end{array}$ & $\begin{array}{l}-0.057 \\
(0.069)\end{array}$ & $\begin{array}{c}0.048^{* * *} \\
(0.016)\end{array}$ \\
\hline $\operatorname{Cov}\left(\varepsilon_{i j}^{k}, e_{i}^{k}\right)$ & $\begin{array}{l}0.078^{* * *} \\
(0.015)\end{array}$ & $\begin{array}{l}0.058^{* * *} \\
(0.007)\end{array}$ & $\begin{array}{l}0.073^{* * *} \\
(0.012)\end{array}$ & $\begin{array}{l}0.049^{* * *} \\
(0.007)\end{array}$ & $\begin{array}{c}0.038^{* * *} \\
(0.004)\end{array}$ \\
\hline Sample Size (N) & 2,769 & 3,094 & 846 & 1,064 & 559 \\
\hline
\end{tabular}

Source: Authors Calculations using IKN 2011 data. Robust Std. Errors in parentheses. ${ }^{* * *}$ signifies over $99 \%$ confidence; ${ }^{* *}$ signifies over $95 \%$ confidence; ${ }^{*}$ signifies over $90 \%$ confidence.

Focusing on the estimated coefficients, as expected, covariance of the error terms from the model for the value of subsidy and the model for the quantity of acquired subsidized goods $\left(\operatorname{Cov}\left(\varepsilon_{i j}^{k}, e_{i}^{k}\right)\right)$ are all positive and significant. This indicates that the value of the subsidy is positively and significantly associated with the quantity of the rationed commodities acquired by the households. However, the model results do not appear to be so well behaved when considering the coefficients for market prices. 
Normally, it would be expected that the transfer value of subsidy increases with market prices. Yet, this expectation holds only for wheat flour with a positive and significant coefficient for market price (0.759). For the remaining goods, the coefficients are not significant and for rice, vegetable oil and sugar, the coefficients are negative.

The coefficients for per capita consumption expenditure are significant and negative for all but vegetable oil. This is a particularly important result to note as it bears significance on the reliability of welfare analysis performed with price opinion data. In effect, this implies that as the level of welfare improves over time, the estimated income transfer due to the subsidy would diminish regardless of whether this is accompanied by a reduction in reliance on the subsidy.

The coefficients for household size are all positive and significant, implying that larger households place a higher value for the subsidy even when holding constant per capita consumption expenditure. The remaining demographic variables (age and sex of household head) are insignificant across the models except for sugar, where the coefficient for the age of household head and its quadratic term are significant albeit with rather small magnitude.

The coefficients for the binary variable indicating whether the household had actually purchased quantities of the rationed commodity in the market within 7 days of the survey are insignificant, the only exception being sugar where households that have purchased this commodity within the reference period of the survey value it 5 percent more, on average, than the remaining households.

Overall, the results indicate that price opinion data produce counterintuitive valuations of the income transfer value of the food subsidy. Referring back to Eq. 6, it is evident that the value of subsidy from the $\mathrm{k}^{\text {th }}$ food commodity $\left(V_{i}^{k}\right)$ should be increasing in quantity $q_{i}^{k}$ and reference market prices. This holds for quantity, as expressed in the significant and positive covariance of the error terms from the value of subsidy model and the quantity model $\left(\operatorname{Cov}\left(\varepsilon_{i j}^{k}, e_{i}^{k}\right)\right)$. However, the model results indicate that value of the food subsidy - and by 
extension price opinion data - is independent of prevailing market prices. The exception being wheat flour where the estimated coefficient is both positive and significant, as it should be.

To estimate the ratio of variance in the dependent variable - the value of subsidy - that is explained by differences between geographic areas a random effects ANOVA is fitted for each commodity and the intra-class correlation $(\hat{\rho})$ is computed as:

$$
\hat{\rho}=\frac{\hat{\tau}_{00}}{\hat{\tau}_{00}+\hat{\sigma}^{2}}
$$

Where $\hat{\tau}_{00}$ represents the variance of level 2 intercept and $\hat{\sigma}^{2}$ is the error variance. These are presented in table 8 below for each of the five commodities.

Table 8: Variance in value of subsidy due to differences across sub-districts

\begin{tabular}{lccccc} 
& \multicolumn{3}{c}{ Wheat } & Veg. & \\
Variance(Constant) $-\hat{\tau}_{00}$ & 0.0516 & 0.0516 & 0.0582 & 0.0326 & 0.0825 \\
\cline { 2 - 6 } Variance(Residual) $-\hat{\sigma}^{2}$ & 0.5100 & 0.4931 & 0.4903 & 0.4186 & 0.4406 \\
ICC $-\hat{\rho}$ & 0.0919 & 0.0947 & 0.1060 & 0.0722 & 0.1577 \\
\hline
\end{tabular}

Source: Authors Calculations using IKN 2011 data.

Differences across sub-districts explain as much as $15.77 \%$ of the variance for the value of subsidy from rationed sugar to as little as $7.2 \%$ for vegetable fat. Naturally, the remaining variance can be expected to be due to individual household factors. For the full model, a "reduction in error variance" pseudo $\mathrm{R}^{2}$ is estimated using

$$
R^{2}=1-\frac{\tau_{00}^{\text {new }}}{\tau_{00}^{\text {old }}}
$$

Where $\tau_{00}^{\text {new }}$ is the total variance from the full fixed effects-random slopes model and $\tau_{00}^{\text {old }}$ is the variance from the random effects ANOVA. 
Table 9: Variance in value of subsidy due to differences across sub-districts

\begin{tabular}{lccccc} 
& Rice & $\begin{array}{c}\text { Wheat } \\
\text { Flour }\end{array}$ & $\begin{array}{c}\text { Veg. } \\
\text { Oil }\end{array}$ & $\begin{array}{c}\text { Veg. } \\
\text { Fat }\end{array}$ & Sugar \\
\cline { 2 - 6 } Variance(ANOVA) $-\tau_{00}^{\text {old }}$ & 0.304 & 0.274 & 0.283 & 0.265 & 0.245 \\
Variance(Full) $-\tau_{00}^{\text {new }}$ & 0.118 & 0.079 & 0.102 & 0.079 & 0.050 \\
Pseudo R & 0.613 & 0.713 & 0.637 & 0.702 & 0.795 \\
\hline
\end{tabular}

Source: Authors Calculations using IKN 2011 data.

As evident in the pseudo $\mathrm{R}^{2}$, accounting for both fixed and random effects explains as much as $79.5 \%$ of the variance in the subsidy transfer value from sugar and only $61.3 \%$ from rice. Compared to the explained variance from the random effects model, variation between sub-districts in market prices and individual household attributes contribute a great deal to explaining the variance in the value of subsidy from the rationed goods.

\subsection{Implications for welfare analysis in Iraq}

The results of the models presented in section 2.8 indicate that individual responses to price opinion questions are not strongly influenced by actual market prices of equivalent commercial commodities and are negatively influenced by general welfare levels.

The implication of this result is illustrated by comparing real growth achieved from 2007 to 2011 in per capita food expenditures - and the prevalence of poverty - valued at actual paid prices with per capita expenditures - and the prevalence of poverty - valued using the price opinions for rationed food commodities.

Expenditure on food

Comparing real growth in expenditure on food valued with paid prices with food valued with price opinions reveals significant differences in estimated growth (see table 10). Compared to 2007, 
real expenditure on food increase by 3.98 percent in 2011 when valued with paid prices. In comparison, real food expenditures valued with price opinions decreased by 0.47 percent during the same period.

Table 10: Growth in total food consumption valued by source of price data among urban households

\begin{tabular}{lccc} 
& $\begin{array}{c}\text { Paid prices } \\
(1000 \\
\text { ID/person/day) }\end{array}$ & $\begin{array}{c}\text { Price opinions } \\
(1000 \\
\text { ID/person/day) }\end{array}$ & $\begin{array}{c}\text { Dietary Energy } \\
\text { Consumption } \\
\text { (kcal/person/day) }\end{array}$ \\
\cline { 2 - 4 } 2007 & 1.44 & $1.65 \mathrm{ID}$ & $2,588 \mathrm{kcal}$ \\
2011 (Q1) & 2.01 & $2.15 \mathrm{ID}$ & $2,738 \mathrm{kcal}$ \\
Nominal Change 2011 & $40.23 \%$ & $29.89 \%$ & --- \\
Real Change 2011* & $3.98 \%$ & $-0.47 \%$ & $5.80 \%$ \\
\hline
\end{tabular}

Source: Authors Calculations. * Food price inflation in 2011 (Q1) is set at 34.86\% for paid prices and $30.51 \%$ for price opinions compared to 2007 in line with the fisher index estimates presented in table 6.

The fact that price opinion data is only applied to rationed food commodities suggests that biases in respondent estimates of price opinion data, as highlighted by the model results presented in section 2.8, accounts for the difference in food expenditure growth rates. During the same period, Dietary Energy Consumption (DEC) increased by 5.8 percent.

Food Price Index estimated with paid prices item weights provides an estimate of inflation (34.86\%) between 2007 and 2011 (Q1), which is fairly close to food price inflation measured by the growth in dietary energy unit values $(32.54 \%)$ that are also estimated with paid prices. The difference between the two measures for paid prices reflects calorie efficient substitutions made by the Iraqi consumer as a result of changing prices. 
Table 11: Dietary Energy Unit Values and Food Price Indices for urban households

\begin{tabular}{lccc} 
& 2007 & $2011(\mathrm{Q} 1)$ & Growth (\%) \\
\cline { 2 - 4 } $\begin{array}{l}\text { Dietary Energy Unit Value (ID/1000 } \\
\text { kcal) - Paid Prices }\end{array}$ & 555 & 735 & $32.54 \%$ \\
$\begin{array}{l}\text { Food Price Index (2007=100) - Paid } \\
\text { Price }\end{array}$ & 100 & 134.86 & $34.86 \%$ \\
$\begin{array}{l}\text { Dietary Energy Unit Value (ID/1000 } \\
\text { kcal) - Price Opinion }\end{array}$ & 639 & 784 & $22.78 \%$ \\
$\begin{array}{l}\text { Food Price Index (2007=100) - Price } \\
\text { Opinion }\end{array}$ & 100 & 130.51 & $30.51 \%$ \\
\hline
\end{tabular}

Source: Authors Calculations

In contrast, significant differences between inflation measured by the Food Price Index calculated with price opinion item weights $(30.51 \%)$ and the inflation measured by the growth in dietary energy unit values $(22.78 \%)$ that are estimated using price opinions. The discrepancies in inflation measured in paid prices and price opinions can be explained through examining the unit values of dietary energy from direct purchases and from the PDS rationed items. These are listed for urban households in table 12.

\section{Table 12: Unit Values of Dietary Energy acquired from direct purchases and the PDS by urban households.}

\begin{tabular}{|c|c|c|c|}
\hline & 2007 & $\begin{array}{l}2011 \\
(Q 1)\end{array}$ & $\begin{array}{l}\text { Growth } \\
(\%)\end{array}$ \\
\hline $\begin{array}{l}\text { Dietary Energy Unit Value of purchased } \\
\text { food (ID/1000 kcal) }\end{array}$ & 1,154 & 1,100 & $-4.62 \%$ \\
\hline $\begin{array}{l}\text { Dietary Energy Unit Value of PDS } \\
\text { rationed food }- \text { Paid Price }\end{array}$ & 0.015 & 0.002 & $-84.82 \%$ \\
\hline $\begin{array}{l}\text { Dietary Energy Unit Value of PDS } \\
\text { rationed food }- \text { Price Opinions }\end{array}$ & 0.175 & 0.160 & $-8.66 \%$ \\
\hline $\begin{array}{l}\text { Contribution of PDS rations to total } \\
\text { calorie consumption }(\%)\end{array}$ & $51 \%$ & $32 \%$ & $-37.19 \%$ \\
\hline
\end{tabular}

Source: Authors Calculations

When evaluated independently, the cost of dietary energy from direct purchases and from the PDS ration have declined in the period between 2007 and the first quarter of 2011 (table 12). On average, 
unit values of dietary energy acquired by urban households decreased by $4.62 \%$ for direct food purchases from the market ${ }^{15}$ and by $84.82 \%$ for food acquired from the PDS. When valued with price opinions, unit values of dietary energy from the PDS also decreased - although only by $8.66 \%$.

With unit values falling for both purchased food and rationed food, it is apparent that the main driver of inflation in food prices faced by the Iraqi consumer is the shift from reliance on the PDS as the major source of dietary energy consumed in Iraq, which provided half of the calories consumed by urban households in 2007, towards the reliance on food purchased on the marketplace.

Following the above, a variation in the estimated growth in overall consumption expenditure can be expected. Growth in per capita monthly expenditures valued with both paid prices and price opinions reveals contradictory trends. When valued with paid prices, average consumption appears to increase slightly in real terms - up by 1.2 percent in 2011. When valued with price opinions, however, average consumption decreases significantly in real terms - down by 4.8 percent in 2011.

\section{Table 13: Real growth in overall consumption expenditures by source of price data (2007-2011)}

\begin{tabular}{lcc} 
& $\begin{array}{c}\text { Paid prices } \\
(1000 \text { ID/person/month) }\end{array}$ & $\begin{array}{c}\text { Market prices } \\
(1000 \\
\text { ID/person/month })\end{array}$ \\
\cline { 2 - 3 } 2007 & 132.2 & 145.8 \\
2011 (nominal) & 174.2 & 180.7 \\
Real growth* (\%) & $1.2 \%$ & $-4.8 \%$ \\
\hline Source: Authors Calculations. & Overall inflation between 2007 and Q1-2011 as \\
measured by the national CPI is 30.2\% &
\end{tabular}

${ }^{15}$ As this reflects direct purchases, no this figure is only estimated with paid prices. 


\section{Poverty line and prevalence}

Setting of the poverty line and estimating the prevalence of poverty using both official prices and price opinions provides further evidence that price opinion data and actual paid prices may lead to different results when focusing on change over time. The poverty line and headcount index is estimated using welfare aggregates calculated with paid prices for commercial goods and price opinions for rationed goods, compared with another welfare aggregate calculated with paid prices for both commercial and rationed goods. These are calculated in 2007 and 2011 to compare the evolution of poverty over time using different price measures for rationed goods.

The poverty line is estimated using the Cost of Basic Needs approach where a food poverty line is set to be equal to the minimum cost of acquiring a balanced $\operatorname{diet}^{16}$ offering 2,100 kilocalories. The cost of 1000 kilocalories in 2007 for the second expenditure decile ${ }^{17}$ was estimated at 389.5 Iraqi Dinars in paid prices and 488.2 Iraqi Dinars when using price opinion data.

The non-food component of the poverty line is defined as the empirical average per capita monthly expenditure on non-food consumption items for those with food expenditures equal to the food poverty line, estimated using the regression method ${ }^{18}$. Spatial price deflators are calculated for each set of price data to deflate the welfare aggregate in both years.

\footnotetext{
${ }^{16}$ A balanced diet here is taken to mean that the contribution of energy-yielding nutrients to total energy ranges from 10 to 15 percent for proteins, from 15 to 30 percent for fats and from 55 to 75 percent for carbohydrates.

${ }^{17}$ Dietary energy unit values for the second decile were used as this is the lowest income group with a balanced diet and where the average dietary energy consumption is at least 2,100 kilocalories per person per day. In this case, average dietary energy consumption for the second poorest decile was 2,120 in 2007.

18 This approach measures the average Engel ratio for households at or near the poverty line, here $\pm 25 \%$ the poverty line, and the non food component of the poverty line is calculated by multiplying the food poverty line by the inverse of the average Engel ratio.
} 


\section{Table 14: Poverty Line and Headcount Index using official prices} and price opinion 2007 and Q1-2011

\begin{tabular}{|c|c|c|c|c|}
\hline & \multicolumn{2}{|c|}{ Paid Prices } & \multicolumn{2}{|c|}{ Price Opinions } \\
\hline & 2007 & $2011 *$ & 2007 & 2011 \\
\hline $\begin{array}{l}\text { Food Poverty Line } \\
\text { (Dinar/Person/Month) }\end{array}$ & 24,878 & --- & 31,184 & --- \\
\hline $\begin{array}{l}\text { Non Food Poverty Line } \\
\text { (Dinar/Person/Month) }\end{array}$ & 40,986 & --- & 40,525 & --- \\
\hline $\begin{array}{l}\text { Poverty Line } \\
\text { (Dinar/Person/Month) }\end{array}$ & 65,864 & 86,451 & 71,709 & 93,365 \\
\hline $\begin{array}{l}\text { Poverty Headcount Index } \\
\text { (Standard Error in } \\
\text { Brackets) }\end{array}$ & $\begin{array}{l}25.87 \% \\
(0.00599)\end{array}$ & $\begin{array}{l}24.09 \% \\
(0.00414)\end{array}$ & $\begin{array}{l}25.28 \% \\
(0.00591)\end{array}$ & $\begin{array}{l}24.99 \% \\
(0.00419)\end{array}$ \\
\hline
\end{tabular}

Source: Authors Calculations. * Published national inflation figures for the period between 2007 and Q1 2011 is 30.2\%

The choice of price data influences the overall poverty line - with the only difference being in the value of the food poverty line component - although the choice of price data does not significantly affect the poverty prevalence at the base year (2007). As is evident in Table 14, the 2007 poverty headcount index is estimated at 25.87 percent when measured using paid prices and 25.28 percent when measured using price opinion data ${ }^{19}$ - virtually equal.

However, it is also apparent that the trend in the evolution in the prevalence of poverty over time deviates depending on the choice of price data. After adjusting the poverty line by accounting for

\footnotetext{
${ }^{19}$ It should be noted that the estimation of the food and non food poverty lines as well as the prevalence of poverty in this paper differs significantly from that estimated and published by the Government of Iraq, with assistance from the World Bank. The main reason for this difference is the lack of sufficient data in the 2011 IKN data set to estimate consumption flow from durable goods. The measure of per capita consumption expenditures used by the Government of Iraq accounted for durable goods. Accordingly, the poverty line was set at 76,896 ID per person per month and the prevalence of poverty was estimated at 22.9 percent. For the purpose of this study, and only to ensure comparability between the 2007 and 2011 measures of welfare, per capita consumption expenditures measured in both 2007 and 2011 did not account for durable goods. As such, these results are not comparable to those estimated by the Government of Iraq.
} 
inflation, the prevalence of poverty using paid prices falls to 24.09 percent in 2011, a statistically significant reduction $(\mathrm{t}=2.44$; $\mathrm{P}=0.0146$ ). In contrast, the prevalence of poverty using price opinion data remains in 2011 statistically equivalent to the 2007 prevalence $(\mathrm{t}=0.402 ; \mathrm{P}=0.688)$.

Recognizing the problem of valuing subsidized PDS items, particularly in light of the difficulty faced in collecting price opinion data, the World Bank (2014) argued in favor of valuing PDS items at the national median of the price opinion data for the estimation of poverty in 2012. Although it is typical to estimate the income transfer value of the subsidy using average prices of substitutes, the benefit of applying this to the welfare aggregate used in poverty measurement is questionable. In the decision to value PDS commodities using the national median of the price opinion data or with official paid prices, it is clear that both would produce the same rank order of households as both the median price opinion data and the official paid prices are constant for all households.

To answer the question of which choice of price data produces more accurate trends of welfare, trends in other indicators of socio economic wellbeing are compared with the poverty trends produced by paid prices and price opinions.

\section{Table 15: Trends in food deprivation, daily wages and unemployment rate between 2007 and 2011}

\begin{tabular}{lcccc} 
& $\begin{array}{c}\text { Food } \\
\text { Deprivation } \\
\text { (Paid Prices) }\end{array}$ & $\begin{array}{c}\text { Food } \\
\text { Deprivation } \\
\text { (Price Opinions) }\end{array}$ & $\begin{array}{c}\text { Avg. Daily } \\
\text { Wages } \\
\text { (ID/day) }\end{array}$ & $\begin{array}{c}\text { Unemploy- } \\
\text { ment rate* }\end{array}$ \\
\cline { 2 - 5 } 2007 & $7.05 \%$ & $7.32 \%$ & 12,000 & $15 \%$ \\
2011 & $5.67 \%$ & $5.71 \%$ & 20,200 & $11 \%$ \\
Growth (\%) & $-19.57 \%$ & $-21.99 \%$ & $29.3 \%$ & $-26.7 \%$ \\
\hline
\end{tabular}

Source: Authors calculation using published inflation rate between 2007 and Q12011 of $30.2 \%$. * Relaxed ILO definition which includes discouraged workers.

As highlighted by the figures in table 15, a number of indicators display an improvement in the standard of living of the Iraqi population between 2007 and 2011. During this period a sizable reduction in violent incidents and insecurity occurred. Statistics on the number of security incidents leading to civilian deaths show an 
improvement with the average number of recorded civilian deaths falling from 747 civilians per month in 2007 down to 129 civilians per month in 2011 due to the conflict ${ }^{20}$. The reduction in violent incidents had a positive impact on the labour market as witnessed by the reduction in overall unemployment rates $(-26.7 \%)$ and the increase in daily wages $(29.3 \%)$.

In addition, the prevalence of food deprivation ${ }^{21}$ (undernourishment) is estimated to have fallen between 2007 and 2011. Table 15 lists the prevalence of food deprivation for both years estimated using paid official prices and price opinions. Although measuring food deprivation relies primarily on kilocalorie consumption, data on consumption expenditures is used to estimate inequality in access to food due to income. Therefore, it is conceivable that the choice of price data could lead to varying estimates of food deprivation. However, the results of food deprivation analysis presented in table 15 suggest that the estimated prevalence of food deprivation is fairly robust to the choice of price data $(7.05 \%$ and $7.32 \%$ in 2007 or $5.67 \%$ and $5.71 \%$ in 2011 ). It follows that the reduction in food deprivation witnessed between 2007 and 2011, along with the reduction in unemployment, increased daily wages and the near six-fold reduction in violence levels during the same period offer greater credibility to the trend in poverty prevalence measured using paid prices.

\subsection{Conclusion}

The choice of price data used in the construction of the welfare aggregate is known, both in theory and in practice, to bear consequences on the validity of welfare analysis.

\footnotetext{
${ }^{20}$ According to Iraq Body Count. https://www.iraqbodycount.org

${ }^{21}$ Food deprivation, or the prevalence of undernourishment, reflects the proportion of the population whose consumption of kilocalories is less than the minimum dietary energy requirements for that population (FAO, 2006). For technical details, see Section 5.3.
} 
In theory, market price data and prices actually faced by consumers are important inputs in the process of creating 'real' welfare measures that allow the ranking of households according to their welfare level (Samuelson, 1974). The problem of the choice of price data arises in the theoretical development of the concept of money metric utility, which is shown to be very sensitive to the choice of reference prices (Blackorby and Donaldson, 1988).

Moreover, the problem of the choice of price data is further complicated where selective consumption subsidies or rationing exist. In such contexts, the policy environment specifically prevents prices from reflecting the market conditions of supply and demand so that prices faced by households could be significantly different depending on the coverage of the policy and strictness of the rationing regime (Hentschel and Lanjouw, 1996).

In practice, welfare analysts invest little effort in considering the source of price data when designing consumption surveys, often leading them to spend precious time 'cleaning' the data after the field work has concluded. Much effort has been invested in developing methods that cope with the drawbacks of the widely used quasi-price measures - unit values (Capéau and Dercon, 2006).

However, little attention has been given to the performance of price opinion data, which is commonly collected in countries with food consumption subsidies. The evidence presented in this paper leads to the conclusion that requesting consumers to directly provide their opinion of the market price of subsidized or rationed food commodities elicits biased responses.

Instead of reflecting market conditions, price opinions of subsidized food commodities are influenced by the importance of the subsidy in the household economy - a reflection of household welfare levels and preferences. The transfer value of the subsidy, estimated as the difference between market price opinions and actual paid, official, prices decreases with rising welfare and is unaffected by prevailing market prices.

Evidence presented in this paper suggests that this bias has implications on welfare analysis. While estimation of the poverty 
headcount in any given year may be equal when estimated using paid official prices or price opinion data, the choice of price data leads to different trends in the growth of consumption expenditure and poverty over time. The results of the estimation models indicate that the transfer value from subsidized commodities, on the whole, decreases with rise welfare, thus counteracting the effect of rising welfare by artificially deflating consumption expenditure.

Observed against the backdrop of other indicators, all of which indicate an improvement in welfare levels between 2007 and 2011, per capita food consumption expenditures and overall consumption expenditures constructed using price opinion data for the subsidized food commodities indicate deterioration in welfare levels. The poverty headcount index estimated using price opinion data shows no improvement in the period between 2007 and 2011 despite the increase in real wages, reduction in unemployment and food deprivation during the same period.

In contrast, using paid prices in constructing consumption expenditures produces a trend that is free of the biases affecting price opinion data and which is consistent with the picture painted by other indicators of wellbeing and standard of living. Consequently, in the context of consumption subsidies and imperfectly imposed rationing, such as that in Iraq, the use of paid prices to value subsidized commodities in constructing a welfare aggregate is preferable to using price opinion data.

This paper contributes to a deeper understanding of the drawbacks associated with the use of respondent price opinions of subsidized or rationed food commodities as proxies for virtual prices. The analysis shows that though price opinions are influenced - as they should be by the quantity of the subsidized good consumed by the respondents, they are also not associated with the market prices of their unsubsidized, free market equivalents. The implication of this in the context of Iraq is the tendency to underestimate the income transfer value of food subsidies and biasing poverty measurement. 


\subsection{Bibliography}

Adams, R. (2000). The Politics of Economic Policy Reform in Developing Countries. Washington, DC.: Policy Research Working Paper No. 2443, World Bank.

Amendola, N., \& Vecchi, G. (2011). Constructing a Welfare Indicator for Poverty Analysis in Iraq. In Confronting Poverty in Iraq (pp. 134-158). Washington, DC: The World Bank and Iraq Poverty Reduction Strategy High Committee.

Beegle, K., De Weerdt, J., Friedman, J., \& Gibson, J. (2010). Methods of Household Consumption Measurement through Surveys. Washington, DC: Policy Research Working Paper (5501), The World Bank.

Blackorby, C., \& Donaldson, D. (1988). Money Metric Utility - A

Harmless Normalization? Journal of Economic Theory , 46, 120129.

Blackorby, C., \& Donaldson, D. (1987). Welfare Ratios and Distributionally Sensitive Cost-Benefit Analysis. Journal of Public Economics , 34, 265-290.

Capéau, B., \& Dercon, S. (2006). Prices, Unit Values and Local Measurement Units in Rural Surveys: an Econometric Approach with an Application to Poverty Measurement in Ethiopia. Journal of African Economies , 15 (2), 181-211.

Crown, W., H. Henk, D. Vanness. (2011). Some Cautions on the Use of Instrumental Variables Estimators in Outcomes Research: How Bias in Instrumental Variables Estimators Is Affected by Instrument Strength, Instrument Contamination, and Sample Size. Value in Health, 14, 1078-1084.

Deaton, A. (1988). Quality, Quantity, and Spatial Variation of Price. American Economic Review, 78 (3), 418-430.

Deaton, A. (1989). Household Survey Data and Pricing Policies in Developing Countries. The World Bank economic review, 3(2), 183-210.

Deaton, A. (1980). The measurement of welfare: Theory and Practical guidelines. Washington, DC: LSMS working paper No. 7, World Bank.

Deaton, A. (1981). Theoretical and Empirical Approaches to Consumer Demand Under Rationing. In A. Deaton, Essays in the Theory 
and Measurement of Consumer Behaviour (pp. 55-72).

Cambridge: Cambridge University Press.

Deaton, A., \& Grosh, M. (2000). Consumption. In M. Grosh, \& P.

Glewwe, Designing Household Survey Questionnaires for

Developing Countries (pp. 91-133). Washington, DC: The World Bank.

Deaton, A., \& Tarozzi, A. (2000). Prices and Poverty in India. Research Program in Development Studies, processed, Princeton, NJ.

Deaton, A., \& Zaidi, S. (2002). Guidelines for Constructing Consumption Aggregates for Welfare Analysis. Washinton, DC: LSMS working paper No. 135, World Bank.

Denny, R., S. Marquart-Pyatt, A. Ligmann-Zielinska, L. Schmitt Olabisi,

L. Rivers, J. Du, L. Liverpool-Tasie. (2017). Food security in Africa: a cross-scale, empirical investigation using structural equation modelling. Environment Systems and Decisions, 38(1), 6-22.

Dréze, J., \& Stern, N. (1990). Policy Reform, Shadow Prices and Market Prices. Journal of Public Economics , 42, 1-45.

FAO. (2006). Measuring Hunger at subnational level: The FAO Approach Applied to Household Survey Data. Rome: Food and Agriculture Organization (FAO).

Frankenberg, E. (2000). Community and price data. In M. Grosh, \& P. Glewwe, Designing Household Survey Questionnaires for Developing Countries (pp. 315-338). Washington, DC: The World Bank.

Gaddis, I. (2016). Prices for Poverty Analysis in Africa. Washinton, DC: World Bank Policy Research Working Paper No. 7652, World Bank.

George, P. (1979). Public Distribution of Food Grains in Kerala Income Distribution Implications and Effectiveness. Washington, DC: International Food Policy Research Institute (IFPRI).

Gibson, J. (2007). A guide to using prices in poverty analysis. Washington, DC: The World Bank.

Gibson, J., \& Rozelle, S. (2002). Is a Picture Worth a Thousand Unit Values?: Price Collection Methods, Poverty Lines and Price Elasticities in Papua New Guinea. Northeast Universities Development Consortium Conference (NEUDC). Williams College's Center for Development Economics. 
Gibson, J., \& Rozelle, S. (2005). Prices and unit values in poverty measurement and tax reform analysis. The World Bank Economic Review , 19 (1), 69-97.

GOI. (2009). Council of Ministers Decision Number 369. Baghdad: Secretariat of the Council of Ministers, Government of Iraq (GOI).

Grosh, M., \& Glewwe, P. (1995). A Guide to Living Standards Measurement Study Surveys and Their Data Sets. Washington, DC: LSMS Working Paper No. 120, World Bank.

GSI. (2010). Subsidy Estimation: A Survey of Current Practice. Geneva: Globak Studies Initiative, International Institute for Sustainable Development.

Hentschel, J., \& Lanjouw, P. (1996). Constructing an Indicator of Consumption for the Analysis of Poverty: Principles and Illustrations with Reference to Ecuador. Washington, DC: LSMS working paper No. 124, World Bank.

Hermida, Richard. (2015). The Problem of Allowing Correlated Errors in Structural Equation Modeling: Concerns and Considerations. Computational Methods in Social Sciences, 3(1), 5-17.

Houthakker, H. (1952). Compensated Changes in Quantities and Qualities Consumer. The Review of Economic Studies, 19(3), 155- 164.

Hueter, Irene. 2016. Latent Instrumental Variables: A Critical Review. Institute for New Economic Thinking Working Paper No.46.

IAU. (2011). Iraq Knowledge Network Survey Tabulation Report.

Baghdad: Information and Analysis UNIT (IAU), United Nations.

Kaul, T. (2014). Household Responses to Food Subsidies: Evidence from India. Maryland: Working Paper, University of Maryland.

Kline, R. B. (2011). Convergence of Structural Equation Modeling And Multilevel Modeling. In M. Williams \& W. P. Vogt (Eds.), Handbook of Methodological Innovation in Social Research Methods (pp. 562-589). London: Sage.

Kline, R. B. (2012). Assumptions of Structural Equation Modeling. In R.

Hoyle (Ed.), Handbook of Structural Equation Modeling (pp. 111-125). New York: Guilford Press.

Kochar, A. (2005). Can Targeted Food Programs Improve Nutrition? An Empirical Analysis of India's Public Distribution System.

Economic Development and Cultural Change , 54 (1), 203-235. 
Lee, L., \& Pitt, M. (1987). Microeconometric Models of Rationing, Imperfect Markets, and Non-Negativity Constraints. Journal of Econometrics , 36, 89-110.

Maynes, E., \& Assum, T. (1982). Informationally Imperfect Consumer Markets: Empirical Findings and Policy Implications. Journal of Consumer Affairs , 16, 62-87.

McKenzie, L. (1957). Demand Theory Without a Utility Index. The Review of Economic Studies, 24(3), 185-189.

McKelvey, C. (2011). Price, unit value, and quality demanded. Journal of Development Economics, 95(2), 157-169.

Mohamed, N., A. Rahman and H. Jenatabadi. (2017). Family Food Security and Children's Environment: A Comprehensive Analysis with Structural Equation Modeling. Sustainability, 9, 1220-1239.

Neary, J., \& Roberts, K. (1980). The Theory of Household Behaviour Under Rationing. European Economic Review , 13, 25-42.

Niimi, Y. (2005). An Analysis of Household Responses to Price Shocks in Vietnam: Can Unit Values Substitute for Market Prices? PRUS Working Paper No.30. University of Sussex.

Ravallion, M. (1998). Poverty Lines in Theory and Practice. Washington, DC: LSMS working paper No. 133, World Bank.

Rothbarth, E. (1941). The measurement of changes in real income under conditions of rationing. Review of Economic Studies , 8, 100107.

Samuelson, P. (1974). Complementarity: An Essay on the 40th Anniversary of the Hicks-Allen Revolution in Demand Theory. Journal of Economic Literature , 12, 1255-1289.

World Bank. (2014). The Unfulfilled Promise of Oil and Growth: Poverty, Inclusion and Welfare in Iraq: Full Report. Washington, DC: World Bank Group.

Zeithaml, V. (1988). Consumer Perceptions of Price, Quality and Value: A Means-End Model and Synthesis of Evidence. Journal of Marketing , 52, 2-22. 


\subsection{Appendices}

\section{Appendix 2A: IKN Ration Module including price opinion}

question

\begin{tabular}{|c|c|c|c|c|c|c|c|}
\hline $\begin{array}{l}\text { ITEM } \\
\text { CODE }\end{array}$ & $\begin{array}{c}\text { When was } \\
\text { the last } \\
\text { time the } \\
\text { house hold } \\
\text { received } \\
\text { the } \\
\text { [ITEM] } \\
\text { from the } \\
\text { agent? } \\
\text { Enter } \\
\text { number of } \\
\text { months } \\
\text { below } \\
\text { * Enter } 0 \text { if } \\
\text { within past } \\
30 \text { days } \\
\text { * Enter } 99 \\
\text { if never } \\
\text { received }\end{array}$ & $\begin{array}{c}\text { What is } \\
\text { the } \\
\text { quantity } \\
\text { of } \\
\text { the } \\
\text { [ITEM] } \\
\text { that you } \\
\text { have } \\
\text { received } \\
\text { the last } \\
\text { time? }\end{array}$ & $\begin{array}{c}\text { How } \\
\text { many } \\
\text { months } \\
\text { are } \\
\text { covered } \\
\text { by this } \\
\text { quantity } \\
?\end{array}$ & $\begin{array}{c}\text { What price } \\
\text { would you pay } \\
\text { to purchase } \\
\text { the } \\
\text { quality of the } \\
\text { [ITEM]? }\end{array}$ & $\begin{array}{c}\text { What was } \\
\text { the } \\
\text { quantity } \\
\text { that you } \\
\text { gave } \\
\text { away } \\
\text { (donated)? } \\
\text { Write } \\
\text { "zero" } \\
\text { if nothing }\end{array}$ & $\begin{array}{l}\text { What was } \\
\text { the } \\
\text { quantity } \\
\text { that you } \\
\text { sold } \\
\text { or traded } \\
\text { of the } \\
\text { [ITEM] } \\
\text { that was } \\
\text { received? }\end{array}$ & $\begin{array}{l}\begin{array}{l}\text { To whom } \\
\text { did you sell } \\
\text { or trade this } \\
\text { [ITEM]? }\end{array} \\
\text { 1. Relative } \\
\text { or friend } \\
\text { 2. Supply } \\
\text { agent } \\
\text { 3. } \\
\text { Restaurant } \\
\text { /workshop } \\
\text { 4. Person } \\
\text { buying } \\
\text { rations } \\
\text { 5. others }\end{array}$ \\
\hline & Item & Quantity & Months & Dinar & Quantity & Quantity & Code \\
\hline 1 & $\begin{array}{l}\text { Wheat } \\
\text { flour }\end{array}$ & & & & & & \\
\hline 2 & Rice & & & & & & \\
\hline 3 & Sugar & & & & & & \\
\hline 4 & $\begin{array}{l}\text { Vegetable } \\
\text { Oil }\end{array}$ & & & & & & \\
\hline 5 & $\begin{array}{l}\text { Vegetable } \\
\text { fat }\end{array}$ & & & & & & \\
\hline 6 & $\begin{array}{l}\text { Powder } \\
\text { milk }\end{array}$ & & & & & & \\
\hline
\end{tabular}




\section{Appendix 2B: Full Structural Equation Model Results}

\begin{tabular}{|c|c|c|c|c|c|}
\hline & Rice & Wheat Flour & Veg. Oil & Veg. Fat & Sugar \\
\hline \multicolumn{6}{|c|}{ Value of Subsidy Model (Eq. 8) } \\
\hline Intercept, $\left(\gamma_{00}\right)$ & $\begin{array}{c}2.423 \\
(1.655)\end{array}$ & $\begin{array}{l}-3.601^{* *} \\
(1.408)\end{array}$ & $\begin{array}{c}1.600 \\
(1.762)\end{array}$ & $\begin{array}{c}0.721 \\
(1.012)\end{array}$ & $\begin{array}{c}2.673 \\
(2.115)\end{array}$ \\
\hline $\mathrm{X},\left(\beta_{01}\right)$ & \multicolumn{5}{|c|}{ Constrained $=1.000$} \\
\hline $\operatorname{Ln}($ Expenditure $),\left(\gamma_{10}\right)$ & $\begin{array}{l}-0.046^{* *} \\
(0.020)\end{array}$ & $\begin{array}{c}-0.059^{* * *} \\
(0.016)\end{array}$ & $\begin{array}{l}-0.024 \\
(0.017)\end{array}$ & $\begin{array}{l}-0.083^{* *} \\
(0.028)\end{array}$ & $\begin{array}{c}-0.032^{* *} \\
(0.013)\end{array}$ \\
\hline household size, $\left(\gamma_{30}\right)$ & $\begin{array}{l}0.140^{* * *} \\
(0.008)\end{array}$ & $\begin{array}{l}0.133^{* * *} \\
(0.006)\end{array}$ & $\begin{array}{l}0.153^{* * *} \\
(0.020)\end{array}$ & $\begin{array}{l}0.115^{* * *} \\
(0.010)\end{array}$ & $\begin{array}{l}0.155^{* * *} \\
(0.009)\end{array}$ \\
\hline $\begin{array}{l}\text { Sex of Household head, } \\
\left(\gamma_{40}\right)\end{array}$ & $\begin{array}{c}0.018 \\
(0.023)\end{array}$ & $\begin{array}{c}0.015 \\
(0.010)\end{array}$ & $\begin{array}{c}0.025 \\
(0.016)\end{array}$ & $\begin{array}{c}0.007 \\
(0.022)\end{array}$ & $\begin{array}{c}0.006 \\
(0.029)\end{array}$ \\
\hline $\begin{array}{l}\text { Age of Household head, } \\
\left(\gamma_{50}\right)\end{array}$ & $\begin{array}{l}-0.000 \\
(0.002)\end{array}$ & $\begin{array}{c}0.003 \\
(0.002)\end{array}$ & $\begin{array}{l}-0.003 \\
(0.003)\end{array}$ & $0.001(0.002)$ & $\begin{array}{c}-0.005^{* * *} \\
(0.002)\end{array}$ \\
\hline $\begin{array}{l}\text { Age of Household head } \\
\text { squared, }\left(\gamma_{60}\right)\end{array}$ & $\begin{array}{c}0.000 \\
(0.000)\end{array}$ & $\begin{array}{c}0.000 \\
(0.000)\end{array}$ & $\begin{array}{c}0.000 \\
(0.000)\end{array}$ & $\begin{array}{c}0.000 \\
(0.000)\end{array}$ & $\begin{array}{c}0.000 * * \\
(0.000)\end{array}$ \\
\hline Purchased, $\left(\gamma_{20}\right)$ & $\begin{array}{l}-0.023 \\
(0.023)\end{array}$ & $\begin{array}{l}-0.020 \\
(0.024)\end{array}$ & $\begin{array}{c}-0.123 \\
(0.129)\end{array}$ & $\begin{array}{c}-0.057 \\
(0.069)\end{array}$ & $\begin{array}{c}0.048^{* * *} \\
(0.016)\end{array}$ \\
\hline $\operatorname{Cov}\left(\varepsilon_{i j}^{k}, e_{i}^{k}\right)$ & $\begin{array}{c}0.078^{* * *} \\
(0.015)\end{array}$ & $\begin{array}{c}0.058^{* * *} \\
(0.007)\end{array}$ & $\begin{array}{c}0.073^{* * *} \\
(0.012)\end{array}$ & $\begin{array}{l}0.049^{* * *} \\
(0.007)\end{array}$ & $\begin{array}{c}0.038^{* * *} \\
(0.004)\end{array}$ \\
\hline \multicolumn{6}{|l|}{ Quantity Model (Eq. 10) } \\
\hline Intercept, $\left(v_{0}^{k}\right)$ & $\begin{array}{c}2.249^{* * *} \\
(1.109)\end{array}$ & $\begin{array}{c}-3.340^{* * *} \\
(0.094)\end{array}$ & $\begin{array}{c}0.835^{* * *} \\
(0.167)\end{array}$ & $\begin{array}{l}1.573^{* * *} \\
(1.012)\end{array}$ & $\begin{array}{l}1.602^{* * *} \\
(0.095)\end{array}$ \\
\hline Ln(Expenditure), $\left(v_{1}^{k}\right)$ & $\begin{array}{c}-0.057^{* * *} \\
(0.015)\end{array}$ & $\begin{array}{c}-0.056^{* * *} \\
(0.013)\end{array}$ & $\begin{array}{c}-0.017 \\
(0.018)\end{array}$ & $\begin{array}{c}-0.076^{* * *} \\
(0.018)\end{array}$ & $\begin{array}{c}-0.035^{* * *} \\
(0.011)\end{array}$ \\
\hline household size, $\left(v_{2}^{k}\right)$ & $\begin{array}{c}0.137^{* * *} \\
(0.007)\end{array}$ & $\begin{array}{c}0.133^{* * *} \\
(0.006)\end{array}$ & $\begin{array}{c}0.156^{* * *} \\
(0.019)\end{array}$ & $\begin{array}{c}0.117^{* * *} \\
(0.008)\end{array}$ & $\begin{array}{c}0.152^{* * *} \\
(0.009)\end{array}$ \\
\hline \multicolumn{6}{|c|}{ Latent Multilevel Model (Eq. 9) } \\
\hline $\operatorname{Ln}($ Price $),\left(\beta_{01}\right)$ & $\begin{array}{l}-0.284 \\
(0.229)\end{array}$ & $\begin{array}{l}0.759^{* * *} \\
(0.200)\end{array}$ & $\begin{array}{c}-0.117 \\
(0.227)\end{array}$ & $\begin{array}{c}0.056 \\
(0.135)\end{array}$ & $\begin{array}{c}-0.234 \\
(0.284)\end{array}$ \\
\hline \multicolumn{6}{|l|}{ Error Variances } \\
\hline$\sigma_{\varepsilon_{i j}^{k}}$ & $\begin{array}{c}0.118 \\
(0.020)\end{array}$ & $\begin{array}{c}0.079 \\
(0.012)\end{array}$ & $\begin{array}{c}0.102 \\
(0.019)\end{array}$ & $\begin{array}{c}0.079 \\
(0.007)\end{array}$ & $\begin{array}{c}0.05 \\
(0.006)\end{array}$ \\
\hline$\sigma_{u_{j}^{k}}$ & $\begin{array}{c}0.054 \\
(0.024)\end{array}$ & $\begin{array}{c}0.025 \\
(0.008)\end{array}$ & $\begin{array}{c}0.014 \\
(0.005)\end{array}$ & $\begin{array}{c}0.015 \\
(0.004)\end{array}$ & $\begin{array}{c}0.005 \\
(0.002)\end{array}$ \\
\hline$\sigma_{e_{i}^{k}}$ & $\begin{array}{c}0.077 \\
(0.015)\end{array}$ & $\begin{array}{c}0.058 \\
(0.007)\end{array}$ & $\begin{array}{c}0.072 \\
(0.011)\end{array}$ & $\begin{array}{c}0.049 \\
(0.007)\end{array}$ & $\begin{array}{c}0.037 \\
(0.003)\end{array}$ \\
\hline Sample Size (N) & 2,769 & 3,094 & 846 & 1,064 & 559 \\
\hline Log Pseudolikelihood & -2337.8 & 1547.3 & 210.5 & -819.0 & 591.9 \\
\hline
\end{tabular}




\section{Ex Ante Cost Effectiveness of Cash and Food Transfers}

\subsection{Introduction}

The old debate surrounding the appropriateness of cash versus food transfers as a mechanism to address food insecurity has recently reemerged in the literature (Gentilini, 2014). Driven by the increased use of cash and near-cash, such as vouchers, by international organizations in humanitarian and development programs, a number of evaluations have shed light on the comparative merits of cash, vouchers and in kind food transfers in improving food security for the recipient (Gentilini, 2016).

The evidence fueling this debate has largely followed separate tracks in developing and developed countries. In developed countries, evidence on cash or food transfers is dominated by literature emerging from the US, particularly surrounding the Supplemental Nutrition Assistance Program (SNAP), formerly known as the food stamp scheme. Contributions to this particular body of evidence were rooted in neo-classical economic thought and began soon after the end of the second world war with the theoretical work of Southworth (1945) whose main contribution was the extension of neo-classical economic theory to the specific case of households receiving food assistance. Southworth postulated that the effects of a food transfer and a cash transfer on food expenditure are equal except for those "constrained households" whose food transfer is extramarginal. The policy implication of this being that a transition to direct cash transfers would not significantly reduce food expenditure since the vast majority of recipient households in the US were "unconstrained" (Fraker T. , 1990).

The majority of empirical research, however, has produced evidence contrary to Southworth's model - specifically that a transition to cash transfers equal in value to the SNAP benefit would significantly reduce expenditure on food. The greater cost effectiveness of 
$\mathrm{SNAP}^{22}$ benefits compared to cash transfers, often referred to as the "cash-out puzzle", have further been confirmed in some of experimental design evaluations (Fraker et al., 1995) though are not yet fully understood (Gentilini, 2007).

In contrast, the debate surrounding cash and food transfers the context of developing countries has been largely "dominated by ideology and politics" (Gilligan et al., 2014) and, until recently, lacking in empirical evidence (Gentilini, 2007). Yet, the use of cash and voucher transfer mechanisms in humanitarian and development interventions has risen steadily in recent years. For instance, the World Food Programme (WFP), an institution that in the past relied almost solely on in kind food transfers, has steadily increased reliance on cash or food vouchers operations, which represented 20 percent of the total value of transfers in 2015 (WFP, 2016). The recent increase in cash and voucher transfers as food assistance mechanisms used by international organizations and questions surrounding the role of social protection mechanisms in addressing food insecurity have led to an increase in impact evaluations using experimental or quasiexperimental evaluation designs specifically investigating the relative effectiveness of cash, vouchers and in kind food transfers (Gentilini, 2014).

Although the evidence from these evaluations is mixed, there are indications from multi country evaluations that value based food vouchers are more cost effective than both in kind food transfers and cash transfers in increasing food consumption (Hidrobo et al., 2014) results that are consistent with empirical research on SNAP in the United States. While the evaluations offer important lessons for the design of food assistance interventions in the contexts in which they were undertaken, they offer little generalized explanation of the differences in cost effectiveness ${ }^{23}$ of cash and food voucher transfers

\footnotetext{
22 The food stamp scheme was formally renamed the Supplemental Nutrition Assistance Program (SNAP) in 2008. For simplicity, this paper will refer to the food stamp scheme as SNAP even when referring to pre 2008 evidence.

${ }^{23}$ Defined simply as the degree or proportion of desired outcomes achieved per unit cost.
} 
in a broad sense, much the less any that is grounded in microeconomic theory ${ }^{24}$.

Consequently, the increased use of cash and value based food voucher transfers in food assistance programmes in developing countries is often justified on the basis of the expected efficiency gains by relying on market food supply chains in contexts where markets function efficiently (Sabates-Wheeler \& Devereux, 2010), rather than relying on government or international organizations' supply chains, and on the basis of the additional flexibility that cash and food vouchers offer to beneficiaries in consuming food in accordance with their preferences (Gilligan et al., 2014).

The poor state of knowledge on the cost effectiveness of cash and food transfers used in food assistance programmes is reflected in the paucity of literature advancing methods for ex ante assessment of cost effectiveness to support the decision making process in designing food security and nutrition interventions. One notable exception is the "Omega Value" (Ryckembusch, et al., 2013), which is a comparative cost effectiveness analysis methodology relied upon by WFP in food assistance intervention design and approval processes. However, the Omega Value methodology is limited to comparing in kind transfers of food packages with food quantities acquired through commodity based vouchers.

This paper explores a general framework rooted in consumer demand theory that incorporates empirical evidence from the "cashout puzzle"

\footnotetext{
${ }^{24}$ Food vouchers generally take two forms. "Value based food vouchers" are vouchers that contain a specified monetary value that can be used only to purchase food without specifying quantities or rations. These vouchers are normally redeemed in local markets, thus rely on market based food supply chains. "Commodity based food vouchers", in contrast, are vouchers that can only be redeemed for a specified food basket with predetermined quantities. The food distributed through commodity based vouchers is often supplied through nonmarket supply chains such as Government or International Organizations. For statements encompassing both forms, these are simply referred to as vouchers in this paper. Vouchers together with in kind food transfers are referred to as food transfers.
} 
literature to develop a nutritional cost effectiveness measure for cash and voucher transfers. Relying on existing literature on the "cash-out puzzle", augmented by empirical evidence from Iraq, regularities in the behavior of consumers receiving food transfers are identified and relied upon in proposing an ex ante cost effectiveness measure for vouchers compared to cash transfers.

The ability to perform ex ante cost effectiveness analysis is useful both in the context of reforming national food assistance schemes as well as in the context of designing development and humanitarian food assistance interventions. For national food assistance schemes, accounting for food and nutrition security considerations during the and after reform processes can help avoid the negative experiences of the structural adjustment programs during the 1980s and 1990s, the bulk of which ignored food security considerations (Weaving, 1996) and which were accused of aggravating food insecurity in Africa (Devereux, 2016). In addition, the ability to undertake ex ante cost effectiveness analysis of food or cash transfer alternatives is of significant value for multilateral organizations such as the World Food Programme, where institutional regulations require the undertaking cost effectiveness analysis when designing development or humanitarian food assistance interventions (WFP, 2014) while the tools currently applied do not enable a direct comparison of food with cash transfers (Ryckembusch, et al., 2013).

Although most of the evidence relied upon in this paper is sourced from published papers emanating from research on the differential consumption responses from cash and food transfers in the United States as well as some papers from developing contexts, additional empirical evidence is generated in this paper using Iraq as the selected case study country. The choice of Iraq is motivated by the fact that the Government is in the process of reforming the national food consumption subsidy scheme, known as the Public Distribution System (PDS) whereas international interventions in the country in response to the humanitarian challenges the country faces encompass cash and food voucher transfers. The Iraq context is also useful since the PDS is a universal subsidy where nearly the entire population is entitled to the benefit. Accordingly, the Iraq context allows a 
comparison of consumption responses to food assistance across the wealth spectrum.

The format of this paper is as follows. Section 2 presents the economic theory underlying the cost effectiveness of cash and food vouchers in stimulating food consumption and the empirical evidence accumulated on the cash-out puzzle. Section 3 presents the empirical approach and data used in estimating the impact of food transfers in the Iraqi context, followed by a presentation of the empirical results in Section 4. Section 5 offers a discussion of the empirical results generated for Iraq, placed within the context of empirical evidence reviewed in Section 2 and elaborates an ex ante cost effectiveness measure of cash and food vouchers. This is followed by concluding remarks in Section 6.

\subsection{Cost effectiveness of cash and food transfers}

The theoretical work of Southworth (1945) informed much of the empirical investigations into the cost effectiveness of the US Food Stamp scheme. Southworth mapped indifference curves for consumer preferences over food and non-food goods when faced with alternative budget constraints resulting from cash transfers, food subsidies or food vouchers ${ }^{25}$. According to this analysis consumer responses to food vouchers (in-kind transfers in Southworth's terminology) would be the same and these would differ from responses to subsidies.

Figure 1 illustrates consumer responses to food assistance in line with Southworth's model.

\footnotetext{
${ }^{25}$ Southworth's work also included analysis of vouchers with purchase requirements similar to the earlier design of the Food Stamp scheme. This is not addressed in this paper.
} 
Figure 1: Consumer responses to food assistance - Southworth's Model



Source: Adapted from Southworth (1945)

According to figure 1, consumers $h$ and $g$ facing the same pre transfer budget constraint (AB) respond differently to the receipt of a food transfer. It is assumed that the minimum possible food consumption is equal to the value of the food transfer, represented by $\mathrm{AD}$, therefore restricting consumer indifference curves to fall on the line DE. According to Southworth, consumer $h$ whose indifference curve would have fallen at the equilibrium point $z$ along the line CD following a regular cash transfer is constrained to higher food consumption than they would prefer. In contrast, for the unconstrained consumers $g-$ whose normal value of food consumption exceeds the value of the transferred food voucher Southworth asserts, based upon the principle of fungibility of money, that the increase in food consumption achieved from a cash transfer is equal to that achieved from a food transfer. In other words, the increase in food consumption with the movement from $g$ to $g^{\prime}$ is equal to the quantity $X$ regardless of whether the outward shift in the budget line is the result of a cash transfer or a food voucher. 
Southworth's analysis of consumer responses to general subsidies corresponds to what would be expected from a price reduction. This is depicted in figure 1 by the dotted line (AE). The responses are formulated on the assumption that households demand for food is less than unit elastic such that the increase in food consumption with the movement from $g$ to $g^{\prime \prime}$ is less than the full value of the food (AD) with some of the subsidy diverted to non-food and is, therefore, less than "100\% effective" (Southworth, 1945, pg.52).

Empirical examination of Southworth's model in relation to the impact of SNAP benefits focused on the proposition that consumer responses to a cash grant and a food voucher are equal - a proposition that has been repeatedly contested. Fraker (1990) lists a table of 17 studies published between 1976 and 1990 that estimate the marginal propensity to consume food from the food stamp scheme is between 2 to 10 times higher than the marginal propensity to consume food from regular cash income, a result that holds even when only considering non-constrained households. Although an anomaly from the perspective of neo-classical economic theory, the repeated assertion of what has come to be known as the cash-out puzzle in empirical literature has also earned it the description of an "empirical regularity" (Gentilini, 2016). Accordingly, one major conclusion of the empirical research on the effects of the food stamps scheme on food consumption has been the assertion that converting the food assistance entitlement to a cash transfer would lead to a reduction in food consumption, contrary to the explicit objective of the scheme. The 'puzzle' in this context is the fact that non-constrained food stamp recipients seem to opt for higher food consumption than they would have had they received an equally valued cash transfer rather than the food stamp.

A number of explanations have been put forth to explain the "cashout puzzle". One explanation is the timing of benefits in the household monthly consumption cycle, as recipient households tend to spend most of their food voucher entitlement immediately after its receipt (Madden \& Yoder, 1971; Smallwood \& Blaylock, 1985; Fraker, 1990; Smith et al, 2016). Fraker (1990) also suggested that the constrained nature of the SNAP benefit may help risk averse households protect their food consumption budgets from exigencies 
and other priorities competing for their limited cash income, thereby leading to higher consumption of food by SNAP recipients.

Levedahl (1995) proposed that welfare recipient stigma, leading to a lower marginal utility of SNAP benefits compared to the marginal utility of regular income, explains the cash-out puzzle. Levedahl's "stigma" explanation was discounted by Breunig and Dasgupta (2002) who later argued that intra-household dynamics, specifically varying preferences over food and non-food consumption between household members, account for the higher marginal propensity to consume food from food stamps (Breunig \& Dasgupta, 2005). More recently, evidence against the assumption of fungibility of money regardless of source and the development of Thaler's (1999) theory of mental accounting has also been applied to explain the cash-out puzzle. According to this theory, households receiving SNAP benefits allocate the benefit to a specific mental account dedicated to food expenditure thereby increasing food expenditure disproportionately more than what would be observed from the regular income (Beatty \& Tuttle, 2014).

A critique of the cash-out puzzle empirical literature has been the failure in much of the published work to address self-selection based endogeneity, under the assumption that households choosing to participate in the food stamp scheme are likely to have a higher preference for food, thereby increasing their marginal propensity to consume food from food stamp income. However, this was explicitly tested in a number of publications that showed very little impact of endogeneity on the estimated food consumption functions (Fraker T. , 1990).

A number of publications assessing the impact of the food stamp scheme on food consumption applied experimental techniques (known as the cash-out experiments) and quasi-experimental methods such as control group matching and difference in difference estimators. Evidence from this body of literature, however, has been mixed. The cash-out experiments, undertaken by the U.S. Department of Agriculture's Food and Nutrition Service in California, Alabama, and Washington State during the late 1980s, showed varying effects by state, though most showed a higher 
marginal propensity to consume food from SNAP benefits, with only one exception - Alabama (Fraker et al, 1995). In contrast, Hoynes and Schanzenbach (2009) applied a difference in difference estimator to panel data collected between 1968-1978, exploiting the staggered rollout of the food stamp scheme across different counties. In line with Southworth's theoretical model and contrary to almost all other empirical evidence, Hoynes and Schanzenbach estimate that the food stamp does significantly increase food consumption, although with a smaller difference in the marginal propensity to consume food from food stamp income compared to regular income, affirming fungibility of regular income and voucher income. Adding to an already mixed picture, recent analysis of retail panel data confirms, again, that the marginal propensity to consume food from SNAP benefits is significantly higher than that for regular cash income (Hastings \& Shapiro, 2017).

The food expenditure models appearing in the empirical literature assessing the impact of the SNAP benefits are generally a direct specification of food expenditures, $F=\alpha_{0}+\beta_{1} Y+\beta_{2} S$, where $F$ represents food expenditure, $Y$ represents regular income or expenditure and $S$ represents SNAP benefits, and with varying functional forms including linear, semi-log, double log and quadratic (Levedahl J. W., 1995). This general model specification enables straight forward estimation of the marginal propensity to consume, particularly for linear, semi-log and quadratic functional forms which are dominant in the "cash-out puzzle literature" (Levedahl, 1995). Some studies applied linear and log-linear budget share specifications as well.

The log-linear budget share specification applied by Moffitt (1989) is a variation of the Working-Leser model (Working, 1943; Leser, 1963) commonly used in modelling consumer decisions on allocating total expenditure between food and non-food commodities and a specification that allows the inclusion of SNAP benefits into Deaton and Muellbauer's Almost Ideal Demand System (Levedahl, 1995). Table 1 lists the main functional forms used in empirical work on food expenditures of food stamp recipients in the USA. 
Table 1: Food expenditure marginal propensity to consume equations in food stamp literature ${ }^{26}$

\begin{tabular}{|c|c|c|}
\hline $\begin{array}{l}\text { Functional } \\
\text { Form }\end{array}$ & Specification & Marginal Propensity to Spend (MPS) \\
\hline Linear & $E=a+b Y+c S_{0}$ & $\begin{array}{l}\operatorname{MPS}(\mathrm{Y})=b \\
\operatorname{MPS}(\mathrm{S})=c\end{array}$ \\
\hline Semi-log & $E=a+b \ln (Y)+c S_{0}$ & $\begin{array}{l}\operatorname{MPS}(\mathrm{Y})=b / Y \\
\operatorname{MPS}(\mathrm{S})=c\end{array}$ \\
\hline Quadratic & $\begin{array}{l}E=a+\left(b_{0}+b_{1} Y\right) Y \\
+\left(c_{0}+c_{1} S_{0}\right) S_{0}\end{array}$ & $\begin{array}{l}\operatorname{MPS}(\mathrm{Y})=b_{0}+2 b_{1} Y \\
\operatorname{MPS}(\mathrm{S})=c_{0}+2 c_{1} S_{0}\end{array}$ \\
\hline $\begin{array}{l}\text { Double } \\
\log \end{array}$ & $\begin{array}{l}\ln (E)=a+b \ln \left(Y+S_{0}\right) \\
+c\left(S_{0} / Y+S_{0}\right)\end{array}$ & $\begin{array}{l}\operatorname{MPS}(\mathrm{Y})=w\left[b-c\left(\frac{S_{0}}{Y}+S_{0}\right)\right] \\
\operatorname{MPS}(\mathrm{S})=w\left[b+c\left(1-\left(\frac{S_{0}}{Y}+S_{0}\right)\right)\right]\end{array}$ \\
\hline $\begin{array}{l}\text { Double } \\
\log \end{array}$ & $\ln (E)=a+b \ln \left(Y+\gamma S_{0}\right)$ & $\begin{array}{l}\operatorname{MPS}(\mathrm{Y})=E b /\left(Y+S_{0}\right) \\
\operatorname{MPS}(\mathrm{S})=\gamma E b /\left(Y+S_{0}\right)\end{array}$ \\
\hline $\begin{array}{l}\text { Share } \\
(\log )\end{array}$ & $w=a+b \ln \left(Y+\gamma S_{0}\right)$ & $\begin{array}{l}\operatorname{MPS}(\mathrm{Y})=w+\left(\frac{b}{Y+\gamma S_{0}}\right)\left(Y+S_{0}\right) \\
\operatorname{MPS}(\mathrm{S})=w+\left(\frac{\gamma b}{Y+\gamma S_{0}}\right)\left(Y+S_{0}\right)\end{array}$ \\
\hline $\begin{array}{l}\text { Share } \\
\text { (linear) }\end{array}$ & $w=a+b\left(Y+\gamma S_{0}\right)$ & $\begin{array}{l}\operatorname{MPS}(\mathrm{Y})=w+b\left(Y+S_{0}\right) \\
\operatorname{MPS}(\mathrm{S})=w+\gamma b\left(Y+S_{0}\right)\end{array}$ \\
\hline
\end{tabular}

Source: Levedahl (1995). MPS(Y) represents marginal propensity to spend/consume from income. MPS(S) represents marginal propensity to spend/consume from food stamps.

It is evident from the review of the cash-out literature that the main metric considered in assessing the impact of SNAP benefits on food consumption is the marginal propensity to consume. It is likely that this is a result of the high reliance on direct specification, particularly the linear, semi-log and quadratic functional forms, in the earlier literature which started taking form in the mid 1970's. Yet, the choice of model specification and functional form was often influenced by goodness of fit rather than theoretical underpinning (Fraker, 1990).

${ }^{26}$ This table excludes equations measuring impact within the framework of quasi experimental studies performed with longitudinal data. 
The more recent Almost Ideal Demand System (Deaton \& Muellbauer, 1980), which is based upon the Working-Leser specification has become widely used in demand modeling, owing to its ease of application and compliance with properties desirable in demand analysis (Buse, 1994) .

In addition, with the expansion of multi-stage budgeting methods by Edgerton (1997), the Working-Leser model has become widely used in demand system estimation, including food demand modelling, particularly in estimating first budgeting stage parameters ${ }^{27}$.

Since demand elasticities are the main demand parameters usually produced through the AIDS demand model and its variants, this paper reformulates the existing evidence for the cash-out puzzle in terms of elasticities. The studies included in Fraker's (1990) sweeping literature review covering the period 1976 to 1990 (table IV.1, pg. 62) are systematically reviewed to extract the relevant information required to approximate income elasticity of demand for food for each of those studies. The marginal propensity to consume food represents the proportion of additional income dedicated to food, ranges from 0 to 1 and is generally denoted as $M P C=\partial f / \partial Y$ where $\mathrm{f}$ is food expenditure and $\mathrm{Y}$ is total income. Income elasticity of demand for food $(\eta)$ represents food consumption response to a $1 \%$ increase in income and is denoted as $\eta \equiv \partial \log (f) / \partial \log (Y)$ and is equal to $\eta=M P C / w$ where $w$ is the share of income devoted to food. Therefore, the information required to approximate elasticities from the mentioned studies is the marginal propensity to consume food from SNAP benefits $\left(M P C^{S}\right)$ and the ratio of income (or

${ }^{27}$ For a review of literature that have applied the Working-Leser specification in a multi-stage food demand system see Tey (2009). 
expenditure) devoted to food ( $w$ ) for the same population for which the $M P C^{S}$ is calculated ${ }^{28}$.

In addition, the review is extended to studies published after 1990, identifying peer reviewed and working papers addressing the impact of food assistance, including food stamps or the more recent SNAP benefits, on food consumption listed in JSTOR and Google Scholar. As with the earlier studies, for those studies that include sufficient information, the income elasticity of demand for food is estimated. While the majority of the post 1990 papers addressed the impact of food stamps/SNAP on food consumption, a few also included analysis of food assistance programmes implemented in developing countries. Of these, one from Zambia and one from Bangladesh included sufficient information required to estimate income elasticity of demand for food and are included in the review. Table 2 presents the studies and reports reviewed and the estimated results.

\footnotetext{
${ }^{28}$ Studies often provide information on the average total income or expenditure and the average total food outlay, from which the Engel ratio can be estimated for the reference population specific to each study. This is not necessarily ideal as there is no certainty that the estimation sample for which the MPC is estimated is also the exact same as that used in calculating mean income and food expenditure. Therefore, the presented elasticities are only approximations, and every effort is made to ensure that they are calculated using information for MPC and the ratio of income devoted to food for the same reference population (i.e. female headed households, or pooled food stamp recipients, constrained food stamp recipients, etc...).
} 
Table 2: Marginal Propensity to Consume Food and Income Demand Elasticity from Selected Studies

\begin{tabular}{|c|c|c|c|c|c|c|}
\hline Study & $\begin{array}{l}\text { MPC } \\
\text { (S) }\end{array}$ & $\begin{array}{c}\text { MPC } \\
(\mathbf{Y})\end{array}$ & $\begin{array}{l}\text { Food } \\
\text { Budget } \\
\text { Share }\end{array}$ & $\begin{array}{c}\text { Food } \\
\text { Assistance } \\
\text { Elasticity }^{\dagger} \\
\eta^{s} \\
\end{array}$ & $\begin{array}{c}\text { Income } \\
\text { Elastici } \\
\mathbf{t y}^{\dagger} \eta^{Y}\end{array}$ & Country \\
\hline $\begin{array}{l}\text { Hymans and Shapiro } \\
(1976)\end{array}$ & 0.350 & 0.140 & 0.387 & 0.905 & 0.362 & USA \\
\hline West and Price (1976) & 0.297 & 0.050 & 0.210 & 1.415 & .238 & USA \\
\hline $\begin{array}{l}\text { Neenan and Davis } \\
\text { (1977) }\end{array}$ & 0.450 & 0.050 & 0.463 & 0.971 & 0.108 & USA \\
\hline $\begin{array}{l}\text { West, Price and Price } \\
(1978)\end{array}$ & 0.310 & 0.030 & 0.359 & 0.863 & 0.084 & USA \\
\hline Salathe (1980) & 0.360 & 0.060 & 0.372 & 0.967 & 0.161 & USA \\
\hline $\begin{array}{l}\text { Chavas and Yeung } \\
(1982)\end{array}$ & 0.370 & 0.126 & 0.329 & 1.125 & $0.383^{*}$ & USA \\
\hline $\begin{array}{l}\text { Allen and Gadson } \\
\text { (1983) }\end{array}$ & 0.295 & 0.076 & 0.328 & 0.899 & 0.232 & USA \\
\hline $\begin{array}{l}\text { Fraker, Long and Post } \\
(1990)\end{array}$ & 0.290 & 0.050 & 0.301 & 0.965 & 0.166 & USA \\
\hline Levedahl (1991) & 0.690 & 0.190 & 0.611 & 1.130 & 0.311 & USA \\
\hline Levedahl (1995) & 0.283 & 0.070 & 0.331 & 0.85 & 0.211 & USA \\
\hline $\begin{array}{l}\text { Wilde and Ranney } \\
\text { (1996) }\end{array}$ & 0.313 & 0.141 & 0.330 & 0.950 & 0.453 & USA \\
\hline $\begin{array}{l}\text { Wilde and Ranneyb } \\
(1996)^{* *}\end{array}$ & 0.220 & 0.312 & 0.502 & .439 & .621 & USA \\
\hline $\begin{array}{l}\text { Breunig and Dasgupta } \\
(2002)\end{array}$ & 0.416 & 0.051 & 0.429 & 0.971 & 0.119 & USA \\
\hline $\begin{array}{l}\text { del Ninno and Dorosh } \\
(2002)\end{array}$ & 0.38 & 0.003 & 0.362 & 1.037 & 0.008 & Bangladesh \\
\hline $\begin{array}{l}\text { Breunig and Dasgupta } \\
(2005)\end{array}$ & 0.312 & 0.084 & 0.346 & 0.902 & 0.243 & USA \\
\hline $\begin{array}{l}\text { Hoynes and } \\
\text { Schanzenbach (2009) }\end{array}$ & 0.163 & 0.087 & 0.179 & 0.911 & 0.480 & USA \\
\hline $\begin{array}{l}\text { Hoynes and } \\
\text { Schanzenbach (2009) }\end{array}$ & 0.296 & 0.098 & 0.287 & 1.031 & 0.341 & USA \\
\hline $\begin{array}{l}\text { Tirivayi and Groot } \\
(2010)\end{array}$ & 0.42 & --- & 0.400 & 1.049 & --- & Zambia \\
\hline Minimum & 0.16 & 0.003 & 0.18 & 0.85 & 0.08 & \\
\hline Maximum & 0.69 & 0.19 & 0.61 & 1.42 & 0.48 & \\
\hline Mean & 0.35 & 0.09 & 0.36 & 1.00 & 0.26 & \\
\hline Std. Dev. & 0.11 & 0.07 & 0.10 & 0.14 & 0.12 & \\
\hline Coef. of Variation & 0.33 & 0.80 & 0.28 & 0.14 & 0.48 & \\
\hline
\end{tabular}

${ }^{\dagger}$ Estimates of income elasticities reported are own calculations based upon information included in the reported studies, namely the share of income (or total expenditure) dedicated to food. * Published in the original study. ** The authors 
of the report attributed this MPC(S) to peculiarities in the research design and sample population. Therefore, it is considered here as an outlier and excluded from the summary statistics. ${ }^{a}$ San Diego sample. ${ }^{b}$ Alabama sample. ${ }^{c}$ Nonelderly Singles and Families. ${ }^{\mathrm{d}}$ Female Headed Households.

The results in Table 2, particularly the elasticity of demand for food due to food assistance $\left(\eta^{\boldsymbol{S}}\right)$ suggest a departure from Engel's law in the presence of food assistance. This sheds some light on the dynamics leading to the repeated rejection of Southworth's theoretical model.

It is noted that the average food assistance income elasticity $\left(\eta^{\boldsymbol{S}}\right)$ across all studies is 1 and ranges only from 0.85 up to 1.42 whereas the Marginal Propensity to Consume due to food assistance, or MPC(S) ranges from a low of 0.16 up to 0.69 . The variation of $\eta^{S}$ across all considered studies $(\mathrm{CV}=0.14)$ is less than half the variation observed for $\mathrm{MPC}(\mathrm{S})$ for the same studies $(\mathrm{CV}=0.33)$. The transition from marginal propensities to elasticities for food assistance reduces the variance by $58.5 \%$ whereas the transition from marginal propensities to elasticities for cash income reduces the variance by $40.1 \%$.

Additionally, it is noted that the estimates for food assistance income elasticity $\left(\eta^{\boldsymbol{S}}\right)$ from Zambia and Bangladesh are both approximately equal to 1 , falling squarely within the range of the 16 remaining estimates from empirical studies in the United States. Naturally, one would expect the income demand elasticity from a wealthy country such the United States to be significantly lower than that estimated for Bangladesh and Zambia. An international comparison of income demand elasticities estimates income elasticity for Zambia and Bangladesh at .805 and .795 respectively, while only at 0.346 for the United States (Muhammad, et al., 2011).

It is important to note that the information in the table was compiled from published reports without access to the original data. It is possible that minor differences exist between the samples used to estimate the marginal propensity to consume and the food budget shares, which were extracted from published articles rather than directly estimated. Also, various model specifications were applied in estimating the marginal propensity to consume in the published 
papers relied upon in the above analysis, ranging from linear specification to quadratic and log linear. These factors, along with other possible sources of inaccuracies in the published data relied upon in the above analysis can, arguably, inflate the variance and reduce the precision of the estimated overall elasticity of demand due to food transfers.

Therefore, the proposition that the food assistance income elasticity of demand for food is approximately equal to 1 is confirmed by directly estimating the elasticity for Iraq. The model specification and estimated results are presented in Sections 3.3 and 3.4 below.

\subsection{Empirical Approach and Data}

To estimate income elasticity $\left(\eta^{Y}\right)$ and food assistance income elasticity $\left(\eta^{S}\right)$ for Iraq, a Working-Leser specification is applied with the inclusion of quadratic terms for cash income and food assistance income to test for non-linearity. This is expressed as

$$
\begin{gathered}
w_{k}=a_{0}+\mathrm{b}_{1} \ln \left(E_{k}\right)+b_{2} \ln \left(R_{k}\right)+b_{3} \ln \left(E_{k}\right)^{2}+b_{4} \ln \left(R_{k}\right)^{2} \\
+b_{5} \ln \left(P_{k}\right)+b_{6} \ln \left(E_{k}\right) \times \ln \left(R_{k}\right)+\sum_{7}^{n} \boldsymbol{b}_{\boldsymbol{n}} \mathbf{Z}_{\mathbf{k}} \\
+\epsilon_{k}
\end{gathered}
$$

In the absence of income data, total expenditure is utilized as a proxy, which is represented as a combination of per capita consumption expenditures $\left(E_{k}\right)$ and $\left(R_{k}\right)$, where $\left(R_{k}\right)$ is the per capita income 
transfer from the Iraqi food transfer scheme ${ }^{29}$ known as the Public Distribution System (PDS). Quadratic terms for $E_{k}$ and $R_{k}$ along with an interaction term are included to test for nonlinearity in the budget share in relation to consumption expenditures and PDS transfer values. $P_{k}$ represents the budget share weighted average food prices paid by the $\mathrm{k}^{\text {th }}$ household and $\mathbf{Z}_{\mathbf{k}}$ a vector of household characteristics, where $b_{1, \ldots,}, b_{n}$ are parameters to be estimated.

Although endogeneity due to self-selection may be a cause for concern, it should be noted that PDS eligibility is near universal and the data shows that the vast majority of Iraqi households (93.25 percent) have acquired food from the PDS during the survey recall period. Following the estimation of the model parameters, we test further for endogeneity and find that the residual from the model is not significantly correlated with $\ln R_{k}$. To double check, a binary treatment regression estimator ${ }^{30}$ is fitted to test for selection effects on the budget share $\left(w_{k}\right)$. Similarly, we find the coefficient for the treatment dummy variable ( $\mathrm{PDS}=1$ if acquired PDS food and 0 otherwise) to be statistically insignificant. Accordingly, no additional treatment for endogeneity is required.

For mean values of $E$ and $R$ and fitted values of $w$, food demand elasticities for cash expenditure $\left(\eta^{\boldsymbol{Y}}\right)$ and food assistance $\left(\eta^{\boldsymbol{S}}\right)$, estimated at means, are derived as

$$
\eta^{Y}=1+\frac{b_{1}+2 b_{3} \ln (E)+b_{6} \ln (\mathrm{R})}{w}
$$

and

\footnotetext{
${ }^{29}$ Since $6.75 \%$ of the sample did not acquire PDS commodities during the survey recall period, a transformation is applied to this variable to avoid the loss of sample resulting from logarithm of zero values. A random constant is therefore added to the cases with zero values as proposed by Johnson \& Rausser (1971) and frequently applied in literature (Sharada, 1999; Dercon, 2006). As bias increases with the size of the constant (Sharada, 1999) the constant applied in this case is set equal to $1.00 \mathrm{E}-04$.

30 Using Stata's < etregress $>$ functionality.
} 


$$
\eta^{S}=1+\frac{b_{2}+2 b_{4} \ln (R)+b_{6} \ln (\mathrm{E})}{w}
$$

\section{Data Source}

Data from the Iraq Household Socio Economic Survey (IHSES), collected from 25,142 Iraqi households in 2012, is used to estimate the model parameters. The IHSES sample is representative at the national, province and district levels and the questionnaire collects detailed data on household consumption expenditures with a diary for food and recurrent non-food expenditures and a recall for nonrecurrent non-food expenditures and a separate recall for the receipt of food commodities from the Public Distribution System (PDS). The PDS is a commodity based food voucher instituted by the Government of Iraq in response to sanctions imposed following the first Gulf War, which continues to this day. Originally a rationing mechanism, the PDS continues to provide the food basket items on a monthly basis to nearly all Iraqi households despite the fact that all equivalents of the PDS food commodities can be freely acquired in Iraqi markets. These are wheat flour, rice, vegetable oil and sugar, plus infant formula for children up to 1 years old. The data on household acquisition of PDS food items includes information on the quantities of food acquired through the PDS, expenditure on PDS items at paid official prices and respondent opinions on the market value of equivalent food commodities.

However, in light of the concerns surrounding the validity of price opinion data in the context of food subsidies discussed in Chapter 2, the transfer income from food vouchers is calculated as the difference between the amount paid by households to acquire the subsidized PDS food items and the average unit value for the same food commodity of similar quality. Spatial price variation and differences in quality preferences are controlled for by calculating mean unit values separately for each decile within every stratum. 


\subsection{Results}

The parameters estimated from Eq. (1) are presented in the table below. It is evident from the regression results that the parameter for the logarithm of cash expenditure $\left(\mathrm{E}_{\mathrm{k}}\right)$ is significantly correlated with the food budget share - confirming that the food budget share linearly decreased with expenditures. The quadratic term for expenditure is barely outside the $90 \%$ confidence interval, though the Wald's test performed for $b_{1}$ and $b_{3}$ indicates that expenditure and its quadratic term are jointly significantly different from zero ${ }^{31}$.

Table 3: Summary of Regression Results (Dep. Variable: Food budget share)

\begin{tabular}{lcccccc} 
& Coefficient & $\begin{array}{c}\text { Robust } \\
\text { Std. Error }\end{array}$ & $\mathrm{T}$ & $\mathrm{P}>\mathrm{t}$ & \multicolumn{2}{c}{$\begin{array}{c}\text { [95\% Conf. } \\
\text { Interval] }\end{array}$} \\
\cline { 2 - 7 } Constant & 0.6111 & 0.0115 & 53.08 & 0.000 & 0.5885 & 0.634 \\
Price index $\left(\mathrm{P}_{\mathrm{k}}\right)$ & 0.0830 & 0.0046 & 18.23 & 0.000 & 0.0741 & 0.0919 \\
Log Expenditure per capita $\left(\mathrm{E}_{\mathrm{k}}\right)$ & -0.046 & 0.0011 & -43.26 & 0.000 & -0.0483 & -0.0441 \\
Log PDS transfer value per & 0.0125 & 0.004 & 2.97 & 0.003 & 0.0043 & 0.0208 \\
capita $\left(\mathrm{R}_{\mathrm{k}}\right)$ & -0.0003 & 0.0002 & -1.66 & 0.097 & -0.0007 & 0.0001 \\
Log Expenditure per capita & 0.0015 & 0.0004 & 3.74 & 0.000 & 0.0007 & 0.0022 \\
square $\left(\ln \left(E_{k}\right)^{2}\right)$ & 0.0078 & 0.0003 & 2.68 & 0.007 & 0.0002 & 0.0013 \\
Log PDS transfer value per & -0.0016 & 0.0027 & -0.58 & 0.565 & -0.0068 & 0.0037 \\
capita $\left(\ln \left(R_{k}\right)^{2}\right)$ & -0.0718 & 0.0023 & -30.60 & 0.000 & -0.0764 & -0.0672 \\
Interaction: $\ln \left(E_{k}\right) \times \ln \left(R_{k}\right)$ & & & & & & \\
Log Household Size & 25,142 & & & & & \\
Locality type (Urban=1) & 0.2687 & & & & & \\
Number of observations & & & & &
\end{tabular}

Source: Own estimations using IHSES 2012.

The parameter for the food assistance transfer value $\left(\mathrm{R}_{\mathrm{k}}\right)$ and its quadratic term are significant and positive. The parameter for per capita expenditures is also significant, although its quadratic term is

${ }^{31} \mathrm{~F}(2,25134)=2290.2 ; \mathrm{P}>\mathrm{F}=0.0000$ 
not. The interaction term between food assistance transfer value and per capita expenditures is significant and positive, indicating the potential for some differential responses to food assistance transfers across the wealth spectrum. The results also indicate that the Engel ratio is significantly associated with locality type, but not with household size. The estimated expenditure and food assistance demand elasticities for food, calculated according to (2) and (3) respectively, are presented in Table 4 below.

Table 4: Cash and food voucher demand elasticities, national and by locality type

\begin{tabular}{lcc} 
& Cash & Food Assistance \\
\cline { 2 - 3 } National & $0.862^{* *}$ & $1.031^{* *}$ \\
& $(0.007)$ & $(0.007)$ \\
\multirow{2}{*}{ Rural } & $0.884^{* *}$ & $1.028^{* *}$ \\
& $(0.006)$ & $(0.007)$ \\
Urban & $0.851^{* *}$ & $1.032^{* *}$ \\
& $(0.008)$ & $(0.007)$
\end{tabular}

Source: Own estimations using IHSES 2012

The cash expenditure demand elasticity ${ }^{32}$ results for Iraq indicate that a 1 percent increase in expenditure results in a 0.862 percent increase in food demand on average. Food assistance elasticities are higher than cash expenditure food demand elasticities for both rural and urban households, echoing the empirical evidence found for the cashout puzzle from the United States, Bangladesh and Zambia. The food assistance elasticity estimated for Iraq, which is estimated at 1.031, falls comfortably within the range of food assistance elasticities calculated for the list of studies included in Table 2. The independent

32 Estimated at means. 
samples t-test ${ }^{33}$ comparing the results for Iraq (Mean=1.031, Std. Dev.=1.13) with the results listed in Table 2 (Mean=1, Std. Dev. $=0.14$ ), fails to reject the null hypothesis of equal means $(\mathrm{t}=0.868, \mathrm{df}=16.43)$ indicating that the food assistance elasticity estimated for Iraq is, statistically, equal to the average elasticity calculated for the list of studies from the USA, Bangladesh and Zambia published between 1976 and 2010. An independent samples t-test confirms that the difference between the rural and urban food assistance demand elasticities for food is also not significant ( $\mathrm{t}=$ 0.814, $\mathrm{df}=24,892.5$ ).

\section{Table 5: Cash and food voucher demand elasticities by decile}

\begin{tabular}{lcc} 
& Cash & Food Assistance \\
\cline { 2 - 3 } Decile 1 & $0.889^{* *}$ & $1.026^{* *}$ \\
Decile 2 & $0.875^{* *}$ & $1.030^{* *}$ \\
Decile 3 & $0.871^{* *}$ & $1.030^{* *}$ \\
Decile 4 & $0.866^{* *}$ & $1.031^{* *}$ \\
Decile 5 & $0.862^{* *}$ & $1.032^{* *}$ \\
Decile 6 & $0.859^{* *}$ & $1.032^{* *}$ \\
Decile 7 & $0.855^{* *}$ & $1.032^{* *}$ \\
Decile 8 & $0.851^{* *}$ & $1.032^{* *}$ \\
Decile 9 & $0.844^{* *}$ & $1.033^{* *}$ \\
Decile 10 & $0.830^{* *}$ & $1.033^{* *}$ \\
\hline
\end{tabular}

Source: Own estimations using IHSES 2012

Table 5 lists expenditure and food assistance demand elasticities for food estimated for each expenditure decile. As is evident in Figure 2, expenditure demand elasticities significantly decrease with income. This is confirmed by the independent samples t-test which rejects the null hypothesis that the expenditure elasticities of the poorest and wealthiest deciles are equal $(t=5.28, d f=2858.04)$. In contrast, food

33 All performed t-test statistics assume unequal variance and obtain degrees of freedom using Welch's formula. 
assistance demand elasticities appear to slightly and insignificantly increase with income. It is clear in figure 5 that food assistance demand elasticity for food among trends slightly upward rising through the wealth deciles, although an independent samples t-test fails to reject the null hypothesis that the food assistance demand elasticity for food for the poorest and wealthiest deciles are equal ( $\mathrm{t}=$ $-0.79, \mathrm{df}=4746.83)$.

Figure 2: Expenditure and Food Assistance demand elasticity of food by decile with upper and lower confidence bounds



\subsection{Discussion}

The results suggest that the elasticity of food demand due to an increase in food assistance is approximately equal to unity. Figure 3 below further illustrates the implications of these results.

The food quantity vector $q^{C}$ represents consumer responses to increased cash income while the quantity vector $q^{F}$ represents consumer responses to food transfers. Panel A illustrates the difference between the increase in food consumption due to an increase in cash income MPC(Y) and that due to an increase in food assistance MPC(S) - typical results of the "cash-out puzzle" and the 
rejection of the Southworth theoretical model. The data belying panel $\mathrm{A}$ are the average $\mathrm{MPC}(\mathrm{Y})$ and $\mathrm{MPC}(\mathrm{S})$ calculated for the list of studies included in table 2 , such that the slope of the quantity vector $q^{F}$ is 0.35 and the slope of the quantity vector $q^{C}$ is 0.09 .

\section{Figure 3: Marginal Propensity to Consume Food and Income Demand Elasticity}
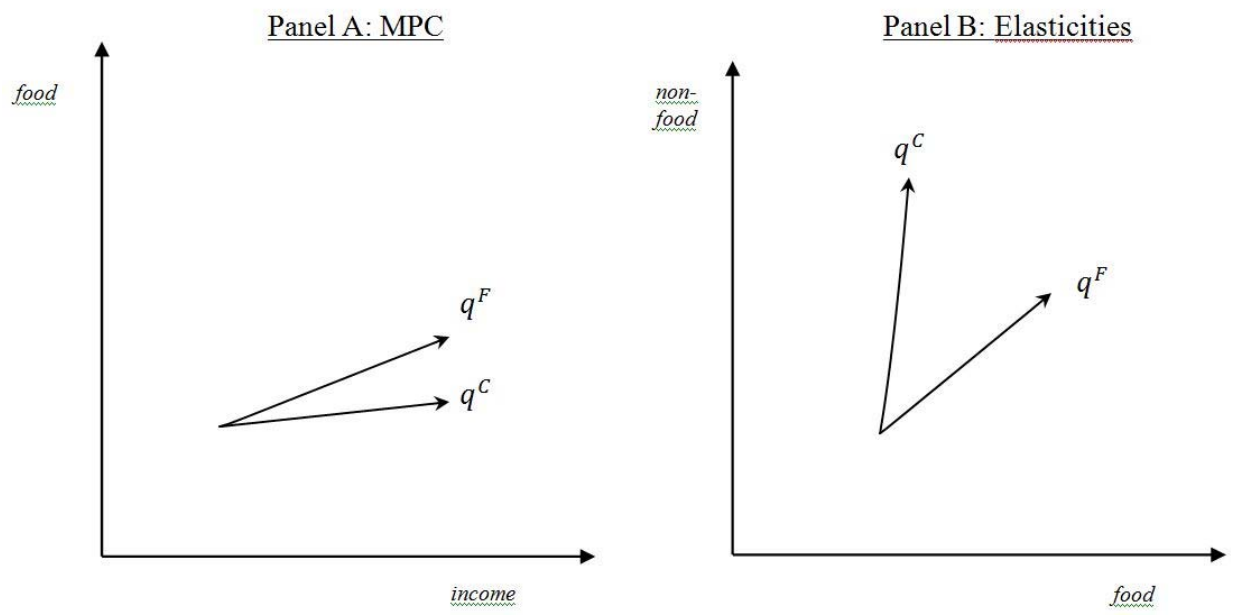

In contrast, Panel B illustrates the difference in allocation of an additional $1 \%$ of income towards food and non-food commodities. The income quantity vector $\left(\mathrm{q}^{\mathrm{C}}\right)$ in panel $\mathrm{B}$ appears to be in line with Engel's law with proportional consumption of food decreasing with higher income. In contrast, the voucher quantity vector $\left(q^{F}\right)$ is linear with a slope of 1 , which implies that an increase in food voucher income leads to an increase in both food and non-food consumption in line with the recipients pre transfer budget share allocation of resources to food and non-food consumption. Importantly, this implies that food assistance transfers do not alter the recipients Engel ratio. Broadly speaking, households appear not to treat food assistance transfers as they would regular income - a claim that was also recently made by Hastings and Shapiro (2017). While food assistance transfers stimulate demand for food, this demand appears to be non-decreasing with income contrary to what is suggested by Engel's law. 
It is evident that neo-classical economic theory fails to account for "cash-out puzzle" (Fraker T. , 1990), though it has been sufficiently observed to the extent that it is described as an "empirical regularity" (Gentilini, 2016). Accordingly, evidence that food demand elasticity due to food assistance tends towards unity is generalized to facilitate the ex-ante analysis of cost effectiveness of food transfers relative to cash transfers.

In the context of food assistance programmes, nutritional cost effectiveness analysis involves the estimation of the cost of achieving transfer outcomes, normally measured in unit of nutrients (i.e. calories, proteins, etc...) (Ryckembusch, et al., 2013). For a single programme, the cost effectiveness ratio can be measured as the additional nutrient consumption per unit cost ${ }^{34}$. Relative cost effectiveness comparing two programmes therefore is the ratio of their cost effectiveness ratios. If the two programmes share the same costs, this collapses to the ratio of the additional nutrient consumption achieved for each programme. Therefore comparing two food transfer programmes delivering the same transfer value per recipient and with equal costs can be estimated as the ratio of food assistance demand elasticity to cash expenditure demand elasticity $\left(\eta^{S} / \eta^{Y}\right)$.

One challenge typically facing ex ante cost effectiveness analysis is the difficulty of estimating the benefits of theoretical benefits before they are rolled out. However, the evidence presented in this paper from contexts as diverse as the United States of America, Iraq, Bangladesh and Zambia imply that the food demand elasticity due to food assistance is approximately equal to 1 . Therefore, relative cost effectiveness of food assistance relative to cash assistance can be approximated by the reciprocal of the income (or expenditure) food demand elasticity. In other words, food assistance cost effectiveness (CE) relative to cash, can be approximated as

${ }^{34}$ Or total additional consumption per total cost if estimated on the aggregate level. 


$$
C E=\frac{\eta^{S}}{\eta^{Y}} \equiv \frac{1}{\eta^{Y}}
$$

This is a particularly useful expression not only for its ease of calculation, but also for its ability to extended cost effectiveness analysis from the expectation of effects of voucher transfers on the broad categories of "food consumption", towards the approximation of cost effectiveness impact on consumption of specific food groups or even beyond to specific food items if that level of detail is available or desired. For example, assuming multi-stage budgeting, the unconditional demand elasticities for the $\mathrm{i}^{\text {th }}$ food commodity $\left(E_{i}\right.$; Edgerton, 1997) in a two stage demand system is specified as

$$
E_{i}=\eta \varepsilon_{i}
$$

where $\eta$ is the first stage income or expenditure food demand elasticity, which can be estimated through a simple working-leser specification and $\varepsilon_{i}$ represents the second stage income/expenditure demand elasticity for the $\mathrm{i}^{\text {th }}$ food commodity estimated through a food demand system.

In the framework of an increase in consumption due to food assistance, unconditional demand for the $i^{\text {th }}$ food commodity is estimated as

$$
E_{i}=\eta_{i}^{S} \varepsilon_{i} \equiv \varepsilon_{i}
$$

In other words, unconditional and conditional food demand elasticities due to food assistance are equal. Applying this to a nutritional cost effectiveness analysis framework where the focus of evaluation is comparing the effects of competing policies or interventions on the consumption of specific food types or nutrients, the comparative cost effectiveness of food assistance relative to cash in increasing consumption of the ith food commodity is specified as

$$
C E_{i} \equiv \frac{\varepsilon_{i}}{\eta_{i}^{Y} \varepsilon_{i}}=\frac{1}{\eta_{i}^{Y}}
$$


meaning that the comparative cost effectiveness measure $\mathrm{CE}$ is the same for individual food commodities as it is for food consumption overall. While the specification in (7) assumes equal cost of implementing voucher and cash transfers, this can be further extended to account for varying implementation costs into

$$
V C E_{i} \equiv \frac{1+a}{\eta_{i}^{Y}(1+b)}
$$

Where the administrative cost associated with cash transfers $(a)$ and the administrative cost associated with food vouchers $(b)$ are both expressed as a proportion of the total aggregate transfer values for each modality. This measure of food assistance cost effectiveness is particularly useful for policy analysts as it enables an ex ante estimation of the relative nutritional cost effectiveness of cash and food assistance, relying almost entirely on the expenditure elasticity $(\eta)$, which can easily be estimated through a single equation model, requiring basic data on total household expenditures and household expenditures on food.

\subsection{Conclusion}

The debate surrounding the effectiveness of in kind, cash and voucher transfers in improving food consumption has been revitalized by the increased reliance on cash and vouchers in international development and humanitarian efforts and by the increased interest in the role of social protection in addressing food security.

Traditionally, this debate has taken separate tracks in developing and developed countries. Much of the evidence on the effectiveness of food assistance and cash transfers emanates from the United States, particularly in relation to the Supplemental Nutrition Assistance Program (SNAP), formerly known as the food stamp scheme. Arguments in favor of replacing SNAP with a cash transfer led to a number of experiments and empirical research regarding the effects of replacing SNAP with cash transfers. However, in developing countries, the debate, dominated by donor countries and international 
organizations, has been more political and less evidence based. The great majority of empirical evidence from the United States suggests that, contrary to theory, income due to cash and food assistance is not fungible, with food assistance leading to greater food consumption than cash transfers of equivalent value. This anomaly has been frequently called the "cash-out puzzle".

This paper reviews the body of evidence surrounding the "cash-out puzzle" from the United States, alongside papers on food assistance from Zambia and Bangladesh, and generates new evidence that addresses the differential expectations of food consumption as a result of food transfers compared to regular cash transfers. By expressing the "cash-out puzzle" in terms of income demand elasticity rather than the marginal propensity to consume remarkably decreases the variability of the estimates, clustering the results closer to the mean food assistance elasticity of 1 . Estimating the same using data from Iraq produces a food assistance demand elasticity of 1.031 which falls comfortably within the range of elasticities estimated from the selected studies.

The food assistance elasticity of demand for food estimated for Iraq is virtually equal at the national and subnational levels - all of which are approximately unit elastic. There are no statistically significant differences in the food assistance elasticity of demand for food between the national, urban and rural average as well as across all expenditure deciles. This, along with the finding that the average elasticities from 14 studies from the United States covering the period between 1976 and 2007, as well as studies from Zambia and Bangladesh is equal to 1 suggests that sufficient evidence exists for the notion that households do not respond to a food transfer in line with Engel's law.

The contribution of this paper to the "cash-out puzzle" literature lies in the demonstration that that demand for food as a result of food assistance - expressed in elasticity form - exhibits a consistent pattern. This is found from published data spanning a period over 30 years and from a variety of contexts and further confirmed empirically using data from Iraq. 
A food demand elasticity due to food assistance equal to 1 implies that food transfers increase both food and non-food demand, yet leave the food budget share unaltered following the transfer. This is contrasted to an increase in regular cash income, or expenditure, where the food budget share generally decreases with rising income in accordance with Engel's law.

This paper also contributes to the growing literature focused on cash and food transfer cost effectiveness analysis. The difference in the consumption response to cash and food assistance is utilized in elaborating a measure of comparative cost effectiveness evaluating the food consumption benefits of a food transfer relative to a cash transfer of equivalent value. This paper suggests that the reciprocal of the expenditure demand elasticity $(\eta)$, normally estimated through a simple single equation model, represents the comparative cost effectiveness of a food transfer in relation to a cash transfer.

Despite the numerous efforts to explain the continued empirical evidence for the "cash-out puzzle", it remains unsolved without an economic theory to account for it. Through reframing the evidence for the "cash-out puzzle", captured across diverse contexts ranging over the course of 3 decades including poor, middle income and wealthy countries, in terms of elasticities, it is hoped that this paper opens up a new avenue for further investigation grounded in microeconomic theory. 


\subsection{Bibliography}

Allen, J., \& Gadson, K. (1983). Nutrient Consumption Patterns of Low-Income Households. Washington, DC: Economic Research Service/USDA, Technical Bulletin No. 1685.

Beatty, T. K., \& Tuttle, C. J. (2014, November). Expenditure

Response to Increase in In-Kind Transfer: Evidence From the Supplemental Nutrition Assistance Program. American Journal of Agricultural Econonomics, 97(2), 390-404.

Breunig, R. V., \& Dasgupta, I. (2002, November). A Theoretical and Empirical Evaluation of the Functional Forms Used to Estimate the Food Expenditure Equation of Food Stamp Recipients: Comment. American Journal of Agricultural Economics, 84(4), 1156- 1160.

Breunig, R. V., \& Dasgupta, I. (2005, August). Do Intra-household Effects Generate The Foof Stamp Cash-Out Puzzle? American Journal of Agricultural Economics, 87(3), 552-568.

Buse, A. (1994, November). Evaluating the Linearized Almost Ideal Demand System. American Economic Review, 76(4), 781793.

Chavas, J., \& Yeung, M. (1982). Effects of the Food Stamp Program on Food Consumption in the Southern United States. Southern Journal of Agricultural Economics, 14, 131-139.

Deaton, A., \& Muellbauer, J. (1980). An Almost Ideal Demand System. American Economic Review, 70(3), 312-326.

del Ninno, C., \& Dorosh, P. (2002). In-Kind Transfers And Household Food Consumption: Implications For Targeted Food Programs In Bangladesh. Washington, DC: International Food Policy Research Institute (IFPRI).

Dercon, S. (2006). Economic reform, growth and the poor: Evidence from rural Ethiopia. Journal of Development Economics, 81, $1-24$.

Devereux, S. (2016). Social protection for enhanced food security in sub-Saharan Africa. Food Policy, 60, 52-62.

Edgerton, D. L. (1997). Weak separability and the estimation of elasticities in multistage demand systems. American Journal of Agricultural Economics, 79(1), 62-79. 
Fraker, T. (1990). Effects of Food Stamps on Food Consumption: A Review of the Literature. Washington, DC: Mathematica Policy Research, Inc.

Fraker, T. M., Martini, A. P., \& Ohls, J. C. (1995). The Effect Of Food Stamp Cashout On Food Expenditures: An Assessment of the Findings From Four Demonstrations. Journal of human resources, 633-649.

Fraker, T., Long, S., \& Post, C. (1990). Analyses of the 1985 Continuing Survey of Food Intakes by Individuals--Volume I, Estimating Usual Dietary Intake, Assessing Dietary Adequacy, and Estimating Program Effects: Applications of Three Advanced Methodologies Using FNS's Four-Day Analysis File. Food and Nutrition Service, USDA. Washington, DC: Mathematica Policy Research.

Gentilini, U. (2007). Cash and Food Transfers: A Primer. World Food Programme, Occasional Paper No. 18. Rome: World Food Programme.

Gentilini, U. (2014). Our Daily Bread: What is the Evidence on Comparing Cash versus Food Transfers? Social Protection and Labour Discussion Paper No. 1420. Washington DC: World Bank.

Gentilini, U. (2014). Our Daily Bread: What is the Evidence on Comparing Cash versus Food Transfers? Social Protection and Labour Discussion Paper No. 1420. Washington, DC: World Bank.

Gentilini, U. (2016, February). Revisiting the 'Cash Versus Food' Debate: New Evidence for an Old Puzzle? World Bank Research Observer, 31(1), 135-167.

Gilligan, D. M., Hoddinott, J., Roy, S., \& Schwab, B. (2014). Much Ado About Modalities: Multicountry Experiments on the Effects of Cash and Food Transfers on Consumption Patterns. Selected Paper prepared for presentation at the Agricultural \& Applied Economics Association's 2014 AAEA Annual Meeting (pp. -). Milwaukee: Agricultural \& Applied Economics Association.

Hastings, J. S., \& Shapiro, J. M. (2017). How Are SNAP Benefits Spent? Evidence from a Retail Panel. NBER Working Paper No. 23112. 
Hidrobo, M., Hoddinott, J., Margolies, A., \& Moreira, V. (2014).

Cash, food, or vouchers? Evidence from a randomized experiment in northern Ecuador. Journal of Development Economics, 107, 144-156.

Hoynes, H. W., \& Schanzenbach, D. W. (2009, October).

Consumption responses to in-kind transfers: Evidence from the introduction of the food stamp program. American Economic Journal: Applied Economics, 1(4), 109-139.

Hymans, S., \& Shapiro, H. (1976). The Allocation of Household Income to Food Consumption. Journal of Econometrics, 4, 167-188.

Johnson, S., \& Rausser, G. (1971). Effects of misspecifications of log-linear functions when sample values are zero or negative. American Journal of Agricultural Economics, 53(1), 120-124.

Leser, C. (1963). Forms of Engel Functions. Econometrica, 31, 694703.

Levedahl, J. (1991). The Effect of Food Stamps and Income on Household Food Expenditures. Washington, DC: Economic Research Service, Technical Bulletin Number 1794.

Levedahl, J. W. (1995, November). A Theoretical and Empirical Evaluation of the Functional Forms Used to Estimate the Food Expenditure Equation of Food Stamp Recipients. American Journal of Agricultural Economics, 77(4), 960- 968.

Madden, J. P., \& Yoder, M. D. (1971). Programe Evaluation: Food Stamps And Commodity Distribution In Rural Areas Of Central Pensylvania. Pennsylvania State Univ., University Park., Department of Agriculture, Washington, DC.

Moffitt, R. (1989, March). Estimating the Value of an In-Kind Transfer: The Case of Food Stamps. Econometrica, 385-409.

Muhammad, A., Seale, J. L., Meade, B., \& Regmi, A. (2011). International Evidence on Food Consumption Patterns: An Update Using 2005 International Comparison Program Data. USDA ERS Technica Bulletin No. 1929. Washington, DC: USDA.

Neenan, P., \& Davis, C. (1977). Impact Of The Food Stamp Program On Low Income Household Food Consumption In Rural Florida. Southern Journal of Agricultural Economics, 9, 8997. 
Ryckembusch, D., Frega, R., Silva, M. G., Gentilini, U., Sanogo, I., Grede, N., \& Brown, L. (2013). Enhancing Nutrition: A New Tool for Ex-Ante Comparison of Commodity-based Vouchers and Food Transfers. World Development, 49, 58-67.

Sabates-Wheeler, R., \& Devereux, S. (2010). Cash Transfers and High Food Prices: Explaining Outcomes on Ethiopia's Productive Safety Net Programme. Future Agricultures Working Paper. Future Agricultures.

Salathe, L. (1980). The Food Stamp Program and Low-Income Households' Food Purchases. Agricultural Economics Research, 32(4), 33-41.

Sharada, W. (1999). The Effects of Education on Farmer Productivity in Rural Ethiopia. Oxford: University of Oxford Centre for the Study of African Economies WPS99-7.

Smallwood, D. M., \& Blaylock, J. R. (1985, July). Analysis of Food Stamp Program Participation and Food Expenditures. Western Journal of Agricultural Economics, 10(1), 41-54.

Smith, T. A., Berning, J. P., Yang, X., Colson, G., \& Dorfman, J. H. (2016). The Effects of Benefit Timing and Income Fungibility on Food Purchasing Decisions among Supplemental Nutrition Assistance Program Households. American Journal of Agricultural Economics, 98(2), 564-580.

Southworth, H. M. (1945, February). The Economics of Public Measures to Subsidize Food Consumption. Journal of Farm Economics, 38-66.

Thaler, R. (1999). Mental Accounting Matters. Journal of Behavioral Decision Making, 12, 183-206.

Tirivayi, N., \& Groot, W. (2010). In Kind Transfers, Household Spending Behaviour and Consumption Responses in HIVaffected Households: Evidence from Zambia. Maastricht: Maastricht University Graduate School Of Governance Working Paper 009.

Weaving, R. (1996). Agricultural adjustment and food policy reform in Mexico. OED Precis No. 117. Washington, DC: World Bank.

West, D., \& Price, D. (1976). The Effects of Income, Assets, Food Programs, and Household Size on Food Consumption. American Journal of Agricultural Economics, 58(4), 725-730. 
West, D., Price, D., \& Price, D. (1978). Impacts of the Food Stamp Program on Value of Food Consumed and Nutrient Intake among Washington Households with 8- 12 Year Old Children. Western Journal of Agricultural Economics, 3, 131-144.

WFP. (2014). Cash and Voucher Manual. Rome: The World Food Programme. Retrieved from https://www.wfp.org

WFP. (2016). Annual Performance Report for 2015. World Food Programme. Rome: World Food Programme.

Wilde, P., \& Ranney, C. (1996). The Distinct Impact of Food Stamps on Food Spending. Journal of Agricultural and Resource Economics, 21(1), 174-185.

Working, H. (1943). Statistical Laws of Family Expenditure. Journal of the American Statistical Association, 38, 43-56. 


\section{Estimating Food and Nutrient Demand Elasticities in Iraq}

\subsection{Introduction}

Understanding household nutrient consumption responses to price and income shocks is crucial to the ability to forecast the impacts of food consumption subsidy reform and to the development of mitigation measures that ensure adequate consumption for those most affected by the reform. Various efforts to understand the impacts of income and price shocks on nutrition can be found in the literature. These range from reduced form demand equations relating demand for nutrients with total expenditure or income and household socio economic and demographic variables to the estimation of nutrient elasticities within the framework of a demand system. A broad literature review by Bouis and Haddad (1992) shows that the former reduced form estimation is much more common.

Generally, studies evaluating demand for food or nutrients apply elasticities to understand expected consumption responses to price and income shocks and, in some cases, to assess the impacts of alternative measures such as cash transfers (as in Ecker \& Qaim (2011) for example).

In spite of the fact that food subsidies are heavily relied upon in the Arab States of the Middles East and North Africa (Sdralevich, Sab, Zouhar, \& Albertin, 2014), very little is known about the structure food and nutrient demand within these countries. For example, metaanalysis of price elasticities performed using published elasticity estimates from 162 countries include data from only 3 Arab states ${ }^{35}$

\footnotetext{
${ }^{35}$ Egypt, Jordan and Saudi Arabia
} 
(Green, et al., 2013). In addition, no published estimates of nutrient elasticities from Arab States can be found and only one instance where the impact of price shocks on nutrition intake in Lebanon is estimated, although through directly applying nutrient conversion factors to estimated consumption of food commodities simulated using regular price elasticities (Abou Zaki, Chaaban, Nasreddine, \& Chalak, 2014).

With all the planning and analysis on reforming the Iraqi Public Distribution System (PDS), none yet have attempted to estimate a complete food demand system for Iraq. Of the few analyses performed on the impacts of proposed PDS reform scenarios, the World Bank and the Government of Iraq estimated that eliminating the PDS would raise poverty by $50 \%$ using survey data collected in 2007 (World Bank \& GOI, 2011), whereas the World Food Programme - using data collected in 2007 as well - estimated a seven-fold increase in food insecurity following an unmitigated elimination of the PDS (WFP, 2008). While neither analysis made use of food demand parameters in the estimation process, it is evident that the PDS serves as a more efficient food consumption instrument than an income transfer mechanism.

Few estimates of food demand elasticities can be found for Iraq. Income demand elasticities for Iraq can be found from the late 1970s, although these were only a few food items and appear to have been based upon assumptions made by the Food and Agriculture Organization of the United Nations (FAO) rather than actual estimates using data collected within the country (El-Sherbini, 1979).

In fact, the most comprehensive list of expenditure and own price elasticities available for Iraq were estimated along with those for 143 other countries using data from the International Comparison Program (Muhammad, Seale, Meade, \& Regmi, 2011). The International Comparison Program (ICP), led by the World Bank, collects aggregate consumption data and detailed prices from 
participating countries in order to produce the PPP deflators allowing cross country comparisons of GDP. Gao (2011) also used the same data to produce aggregate food income and own price elasticities for 138 countries, including Iraq. While these estimates are useful, they are produced with aggregate national data where the records reflect countries not individual households or individuals, thus can be useful in policy analysis focused on regional or global issues rather than within-country disaggregated analysis (Shimeles, 2010).

Most recently, Krishnan, Olivieri and Ramadan (2017) applied a mixed demand model to estimate income and price demand elasticities for Iraq, though accounting only for PDS food items and their market equivalent commodity groups. The approach they followed provides elasticities for a subset of food consumed in Iraq, excluding important food groups such as vegetables, fruits, dairy products and meat. Accordingly, the demand system estimated by Krishnan et al. represents only 35 percent of total food expenditures or only 12.95 percent of total consumption expenditure considering that the ratio of all food expenditures from total consumption expenditure in Iraq is 37 percent. While the work of Krishnan et al. is an important development in the efforts to shed light the welfare effects of PDS reform, the mixed demand model they applied produces elasticities that are conditional on expenditures limited only to the commodities included in the estimated demand system. Conditional elasticities are of limited value (Moschini, Moro, \& Green, 1994) and - at best - produce partial welfare measures such as compensating variation (Hanemann \& Morey, 1992).

In addition, there are no published studies with estimates of nutrient demand elasticities for Iraq. Understanding nutrient consumption responses to PDS reform using nutrient demand elasticities would therefore offer policy makers invaluable information regarding the nutritional implications of eliminating PDS consumption subsidies. Importantly, nutrient demand elasticities can be used as necessary 
inputs for ex ante nutritional cost effectiveness analysis comparing alternative measures designed to mitigate the negative effects of reform.

There is a growing trend of extending food demand system analysis to produce nutrient demand elasticities. Building upon earlier work in nutrient elasticity estimation by Pitt (1983) in Bangladesh, Sahn (1988) in Sri Lanka and Huang (1996) in the United States, Ecker and Qaim (2011) estimate nutrient elasticities in a multistage food demand system, where they examine the nutritional impacts of food subsidies and price shocks on nutrient consumption in Malawi. Yu \& Shimokawa (2016) subsequently applied this approach for six other African countries.

This paper builds upon the approach followed by Ecker and Qaim (2011) in estimating food and nutrient demand elasticities. Using data from Iraq, the parameters of a complete food demand system is estimated applying a three stage budgeting approach.

The format of this paper is as follows. Section 2 provides information on the context of food subsidies in Iraq and details on the data used in the analysis as well as a national and subnational analysis of nutrient intake and undernourishment. Section 3 outlines the methodologies applied in estimating the food demand system and derived elasticities. This is followed by a presentation of Iraqi food and nutrient demand elasticities in section 4 and concluding remarks in Section 7.

\subsection{Data}

This paper utilizes the Iraq Household Socio Economic Survey (IHSES) with data collected from 25,142 households during 2012. By design, the survey sample is representative at the national, province and district levels and the questionnaire collects detailed 
data on household consumption expenditures with a diary for food and recurrent non-food expenditures and a recall for non-recurrent non-food expenditures. Data on household acquisition of PDS food items is collected through a separate section, which provides information on the quantities of food acquired through the PDS, expenditure on PDS items and respondent opinions on the market value of equivalent food commodities.

The food diary provides data on the acquisition of 235 food items acquired through a variety of sources such as purchases, own production, gifts and barter. For the analysis of undernourishment and nutrient intake, the data on acquired quantities are adjusted to account for edible portions (i.e. excluding banana peels) then nutrient conversion factors are applied to estimate the total nutrient availability at the household level for a list of 10 nutrients including protein, carbohydrate, fat, fiber, alcohol, iron, zinc, folate, vitamin A and vitamin B12. Kilocalorie availability is extracted from information on the availability of proteins, carbohydrates, fat, fiber and alcohol in line with FAO guidelines ${ }^{36}$. The nutrient conversion factors applied to the data are from the nutrition composition table applied previously in $\operatorname{Iraq}^{37}$.

Finally, outliers in expenditure or quantity data are flagged by identifying cases where the logarithm of unit values lies outside 2 standard deviations from the mean and replaced using decile and location median values, expanding location sequentially from cluster to district to governorate to environment (urban/rural) until at least 10 cases are available for the median to be calculated. Overall, this

${ }^{36}$ These follow the Atwater general factor system as described by Sibrián et al. (2007): kilocalories $=\left(\right.$ protein $\left._{\mathrm{gr}} \times 4\right)+\left(\right.$ fat $\left._{\mathrm{gr}} \times 9\right)+\left(\right.$ carbohydrates $\left._{\mathrm{gr}} \times 4\right)+\left(\right.$ fiber $_{\mathrm{gr}} \mathrm{x}$ 2) $+($ alcoholgr $\times 7)$.

${ }^{37}$ Available upon request from the authors. 
approach flagged and imputed 4.8 percent of the records included in the food diary.

Analysis of the 2012 IHSES data ${ }^{38}$ indicates that average kilocalorie consumption in 2012 is 2972 per person daily ${ }^{39}$, an increase from 2,810 measured in 2011 (WFP \& GOI, 2012). Table 1 presents intake levels of the considered macro and micro nutrients nationally and by decile. The proportion of calories from various sources indicate, on average, a balanced $\operatorname{diet}^{40}$ in macronutrient terms across deciles. On average, 57.8 percent of calories consumed are from carbohydrates, 24.0 percent are from fats and 11.8 percent are from protein sources. The balance of diet remains well within the acceptable range regardless of income, except for the wealthiest decile where the proportion of calories from fats is at the upper limits of the acceptable range. The wealthiest decile consumed approximately twice as many calories, proteins and carbohydrates as the poorest decile and nearly 4 times more fat.

\footnotetext{
${ }^{38}$ Sampling weights are applied in the analysis of the survey data as well as in the demand system estimation.

${ }^{39}$ Given that the IHSES questionnaire collects data on household acquisition of food, the estimates produced using the IHSES data reflect Dietary Energy Acquisition (DEA), not Dietary Energy Consumption (DEC). DEA reflects the upper bounds of the possible DEC, with DEC usually being less than DEA due to wastage and sharing of acquired food with visitors and others. Without any further information on wastage or the sharing of food, and for ease of reference, this paper will consider kilocalories estimated from the data to reflect DEC.

${ }^{40}$ The FAO/WHO/UNU recommendations for a balanced diet proposes of 10-15 percent of calories from protein, 15-30 percent from fats and 55-75 percent of carbohydrate sources (Sibrián et al., 2007).
} 
Table 1: Macro and micronutrient consumption (per capita daily) nationally and by decile

\begin{tabular}{lccccccccc} 
& $\begin{array}{l}\text { Dietary } \\
\text { Energy } \\
(\mathrm{kc})\end{array}$ & $\begin{array}{l}\text { Protein } \\
(\mathrm{g})\end{array}$ & $\begin{array}{l}\text { Fat } \\
(\mathrm{g})\end{array}$ & $\begin{array}{l}\text { Carbo- } \\
\text { hydrates } \\
(\mathrm{g})\end{array}$ & $\begin{array}{l}\text { Iron } \\
(\mathrm{mg})\end{array}$ & $\begin{array}{l}\text { Zinc } \\
(\mathrm{mg})\end{array}$ & $\begin{array}{l}\text { Folate } \\
(\mathrm{m})\end{array}$ & $\begin{array}{l}\text { Vit. A } \\
(\mathrm{IU})\end{array}$ & $\begin{array}{l}\text { Vit. } \\
\text { B12 } \\
(\mathrm{mcg})\end{array}$ \\
\cline { 2 - 9 } Decile 1 & 2198 & 65.4 & 47.4 & 346.7 & 19.6 & 12.2 & 239.4 & 2533.5 & 0.9 \\
Decile 2 & 2493 & 75.5 & 57.4 & 382.2 & 22.1 & 13.9 & 309.2 & 3418.0 & 1.4 \\
Decile 3 & 2671 & 79.8 & 66.0 & 399.1 & 23.0 & 14.4 & 348.4 & 4225.9 & 1.6 \\
Decile 4 & 2800 & 82.8 & 71.3 & 413.8 & 23.6 & 14.9 & 376.8 & 4708.2 & 1.8 \\
Decile 5 & 3005 & 88.1 & 79.1 & 433.6 & 24.6 & 15.7 & 409.1 & 4935.1 & 2.0 \\
Decile 6 & 3168 & 93.4 & 87.6 & 452.5 & 25.9 & 16.5 & 443.1 & 5725.7 & 2.3 \\
Decile 7 & 3386 & 98.2 & 97.3 & 474.2 & 26.7 & 17.1 & 492.9 & 6230.3 & 2.5 \\
Decile 8 & 3720 & 107.3 & 110.4 & 505.5 & 28.9 & 18.6 & 538.7 & 7045.0 & 2.9 \\
Decile 9 & 3988 & 116.0 & 125.9 & 525.8 & 30.9 & 20.0 & 634.2 & 8323.7 & 3.5 \\
Decile 10 & 5122 & 149.2 & 170.9 & 655.1 & 37.1 & 25.1 & 789.6 & 11610.8 & 5.1 \\
National & 2972 & 87.6 & 79.2 & 429.6 & 24.6 & 15.6 & 402.8 & 4999.8 & 2.0 \\
\hline
\end{tabular}

Source: Own calculation using IHSES 2012

In terms of micronutrients, the average of $2 \mathrm{mcg}$ consumption of Vitamin B12 daily is considered grossly inadequate considering the estimated average requirement for the Iraqi population of $2.8 \mathrm{mcg}$ daily, though this is consistent with previous results from 2011 for Iraq as 52 percent of the population were estimated to have inadequate access to Vitamin B12 (WFP \& GOI, 2012). This is explained by the relatively higher cost of animal products, the main source of Vitamin B12. The greatest disparity in micronutrient consumption is observed for Vitamins B12 which was consumed 4.6 times more by the wealthiest decile than by the poorest. 
Table 2: Contribution of food groups to nutrient consumption

\begin{tabular}{lcccccccc} 
& $\begin{array}{c}\text { Cereals } \\
\& \\
\text { Cereal } \\
\text { Products }\end{array}$ & $\begin{array}{c}\text { Vegetables } \\
\text { Vegetable } \\
\text { Products }\end{array}$ & $\begin{array}{c}\text { Fruits \& } \\
\text { Fruit } \\
\text { Croducts }\end{array}$ & $\begin{array}{c}\text { Oils } \\
\text { Fats }\end{array}$ & $\begin{array}{c}\text { Fish, } \\
\text { Meat } \\
\text { Eggs }\end{array}$ & $\begin{array}{c}\text { Milk \& } \\
\text { Dairy } \\
\text { Product } \\
\text { s }\end{array}$ & $\begin{array}{c}\text { Sugars } \\
\& \\
\text { Syrups }\end{array}$ & Misc. \\
Protein & $57 \%$ & $7 \%$ & $3 \%$ & $12 \%$ & $6 \%$ & $3 \%$ & $10 \%$ & $2 \%$ \\
Fat & $58 \%$ & $13 \%$ & $1 \%$ & $0 \%$ & $21 \%$ & $5 \%$ & $1 \%$ & $2 \%$ \\
Carbohydrates & $23 \%$ & $1 \%$ & $1 \%$ & $47 \%$ & $15 \%$ & $7 \%$ & $2 \%$ & $4 \%$ \\
Iron & $70 \%$ & $7 \%$ & $4 \%$ & $0 \%$ & $0 \%$ & $1 \%$ & $16 \%$ & $1 \%$ \\
Zinc & $63 \%$ & $17 \%$ & $2 \%$ & $0 \%$ & $8 \%$ & $3 \%$ & $5 \%$ & $3 \%$ \\
Folate & $64 \%$ & $13 \%$ & $1 \%$ & $0 \%$ & $14 \%$ & $4 \%$ & $1 \%$ & $2 \%$ \\
Vitamin A & $31 \%$ & $50 \%$ & $5 \%$ & $0 \%$ & $5 \%$ & $2 \%$ & $0 \%$ & $8 \%$ \\
Vitamin B12 & $1 \%$ & $70 \%$ & $11 \%$ & $0 \%$ & $5 \%$ & $13 \%$ & $0 \%$ & $0 \%$ \\
\hline
\end{tabular}

Source: Own calculation using IHSES 2012

The contribution of the food groups to nutrient consumption indicates that cereals and cereal products provide most of the calories, proteins, carbohydrates, iron and zinc consumed by Iraqi households. Vegetables are the main source of Vitamin A and Folate, while meat and eggs are the main source of vitamin B12.

\subsection{Methodology}

The analysis of the impacts of food subsidy elimination requires estimates of food demand elasticities. Given the context of Iraqi food subsidy regime, the choice of model specification and functional form is important.

The fact that the PDS was initially designed as a rationing mechanism to cope with wartime food shortages, suggests the need for specification that explicitly addresses rationing and dual pricing regimes, such as that proposed by Wang and Kinsey (1994), which is a variation of the Deaton and Muellbauer's Almost Ideal Demand System (AIDS) (1980), or Moschini and Rizzi's (2007) Normalized 
Quadratic Mixed Demand model, which was applied by Ramadan and Thomas (2011) in estimating Egyptian food demand parameters or more recently by the World Bank in Iraq (2014).

A recent analysis by Krishnan et al. (2017), whose results were previously reported in a World Bank report on Iraq (2014), favored the Mixed Demand model for Iraq over the popular AIDS model based upon the nonlinearities introduced to the demand functions due to the individual ration quotas. However, empirical applications of the Mixed Demand model have dealt with corner solutions due to zero expenditure through aggregating the data by primary sampling unit and expenditure quantile, which entails a significant loss of detail (Ramadan \& Thomas, 2011; Krishnan, Olivieri, \& Ramadan, 2017).

Crucially, the context in Iraq is such that the PDS can hardly be considered a rationing system. Households are free to acquire any quantity desired for the same items included in the PDS food basket from commercial outlets; therefore, no strict rationing of quantities is effectively imposed. In addition, there is significant variation in the supply of food through the PDS both spatially and temporally (UN \& GOI, 2011) due to inefficient supply chain management, leading households across the income distribution to increasingly acquire food through commercial outlets (WFP \& GOI, 2012). The Iraqi PDS can thus be loosely characterized as a food consumption subsidy regime that allows Iraqi households to face reduced prices during the months when PDS food supplies reach the market.

Nonetheless, valuing food commodities acquired through the PDS requires careful consideration. To ensure the estimation of reliable food demand elasticities, this paper relies on the body of literature building upon the work of Neary and Roberts (1980) relating the properties of rationed demand to the properties of unrationed demand using virtual prices. The virtual price of a good reflects the price level that results in the observed consumer demand as estimated in a free, unconstrained demand system. Neary and Roberts show that the 
derivative of rationed demand with regard to prices and income can be expressed in terms of the derivative of the corresponding unconstrained demand with regard to the same exogenous variables when evaluated at virtual prices.

Following Neary and Roberts (1980), the expression of rationed demand in terms of unconstrained demand and virtual prices has been applied in the analysis of rent control and house rationing in Belgium (Bettendorf \& Buyst, 1997; Fleissig \& Whitney, 2014). In Poland, consumer demand equations have also been estimated using virtual prices (Huffman \& Johnson, 2004; Starzec \& Gardes, 2014). Fleissig $\&$ Whitney (2014) estimate a Rotterdam model using virtual prices to estimate demand elasticities for rationed food and non-food goods during the post Second World War period in the UK. Similarly, Winkler (2015) estimates the Quadratic Almost Ideal Demand System (QUAIDS) using virtual prices to assess the impact of food price controls in Nazi Germany.

The QUAIDS model (Banks, Blundell, \& Lewbel, 1997) is often applied in modeling food demand in both developed and developing countries. For example, QUAIDS has been applied in food demand system analysis in the USA (Lakkakula, Schmitz, \& Ripplinger, 2016), Germany (Winkler, 2015), Canada (Lambert, Larue, Yelou, \& Criner, 2006), Switzerland (Abdulai, 2002) and Italy (Moro \& Sckokai, 2000). In addition, it has been applied in numerous published works in the context of developing countries. Abdulai and Aubert (2004) applied the QUAIDS model to estimate food demand in Tanzania and Fashogbon and Oni (2013) applied it in Nigeria.

The QUAIDS has also been applied in contexts of developing countries with public food distribution schemes such as India (Anand, Kumar, \& Tulin, 2016; Kumar, Kumar, Parappurathu, \& Raju, 2011; Mittal, 2010) and Indonesia (Widarjono, 2012) where consumption of rationed food items were included at paid prices without additional treatment. Moreover, Ecker and Qaim (2011) applied QUAIDS in 
Malawi, which is also a context where consumption subsidies exist. The Malawi and Indonesia examples are particularly relevant as they also estimate nutrient elasticities, and in the case of Malawi, analyze the impact of subsidy on nutrient intake. Given the similarity in objectives, and the ability of the QUAIDS model to handle nonlinear demand, the research presented in this paper will follow the example set by Ecker and Qaim.

By definition, virtual prices reflect the price level that result in the observed consumer demand for the PDS commodities. Therefore, PDS food items are valued at their estimated virtual prices and included in an unconstrained QUAIDS model to yield "free" demand elasticities.

\section{Virtual prices}

To estimate virtual prices for food items acquired through the PDS, Moschini and Rizzi's (2007) mixed demand model is applied. This is particularly convenient as the formulation of the mixed demand model includes an explicit estimation of virtual prices for quantity constrained goods. For the vector of commodities acquired at market prices with the price vector $\boldsymbol{p}$ and the vector of PDS commodities acquired at fixed quantities with the quantity vector $\boldsymbol{Z}$ and utility level $u$, Moschini and Rizzi define the mixed cost function as

$$
C^{M}(p, z, u) \equiv C(p, z, u)-\nabla_{z} C(p, z, u) \cdot z
$$

such that 


$$
C^{M}\left(p, z, V^{M}(p, z, y)\right) \equiv y
$$

where $y$ represents total consumption expenditure and $V^{M}(p, z, y)$ is the mixed utility function. To avoid disequilibrium in the model resulting from rationing in solving for the mixed utility function, $V^{M}(p, z, y)$, PDS goods are valued at their virtual prices $q^{h}(p, z, u)$ where

$$
\nabla_{z} C(p, z, u)=-q^{h}(p, z, u)
$$

According to the normalized quadratic parameterization, the virtual price $\left(q_{k}\right)$ of the $\mathrm{k}^{\text {th }}$ PDS commodity is specified as

$$
\begin{aligned}
-q_{k}=\left(\sum_{i=1}^{n} a_{i} p_{i}\right) & \mu_{k} \\
+ & {\left[\left(\sum_{i=1}^{n} a_{i} p_{i}\right) \gamma_{k}+\left(\sum_{i=1}^{n} a_{i} p_{i}\right)\left(\sum_{s=1}^{m} \gamma_{k s} z_{s}\right)\right.} \\
+ & \left.\left(\sum_{j=1}^{n} \lambda_{j k} p_{j}\right)\right] \cdot V^{M}
\end{aligned}
$$

where $V^{M}$ is the mixed utility function specified as 


$$
V^{M}=y-\left(\sum_{i=1}^{n} \delta_{i} p_{i}\right) / \begin{gathered}
\left(\sum_{i=1}^{n} \beta_{i} p_{i}\right)+\frac{1}{2} \frac{\sum_{i=1}^{n}\left(\sum_{j=1}^{n} \beta_{i j} p_{j}\right) p_{i}}{\sum_{i=1}^{n} a_{i} p_{i}}+ \\
\frac{1}{2}\left(\sum_{i=1}^{n} a_{i} p_{i}\right)\left(\sum_{s=1}^{m}\left(\sum_{k=1}^{m} z_{k} \gamma_{k s} z_{s}\right)\right)
\end{gathered}
$$

and where $\gamma_{k}, \lambda_{j k}, \gamma_{k s}, \delta_{i}, \mu_{k}$ and $\beta_{i}$ are parameters to be estimated. The parameters $a_{i}$ are set equal to average budget share of market only food commodities such that $\sum_{i=1}^{n} a_{i}=1$. For the purpose of estimation, Moschini and Rizzi express the mixed demand system in budget share terms where, for PDS commodities ${ }^{41}$, the budget share is expressed as $w_{k}=q_{k} z_{k} / y$.

To address the problem of zero consumption in the survey data, Shonkwiler and Yen's (1999) two step procedure is applied where probit models are estimated in the first step, where the dependent variable $\left(\omega_{k t}\right)$ is a binary variable equal to 1 if the $t^{\text {th }}$ household acquired the $\mathrm{k}^{\text {th }}$ commodity during the reference period and 0 otherwise, and where $\boldsymbol{x}_{\boldsymbol{t}}$ is a vector of household socio economic and demographic characteristics entered as independent variables. The estimated probit parameters are used to produce the univariate standard probability density $\phi\left(\boldsymbol{x}_{\boldsymbol{t}}^{\prime} \widehat{\omega}_{k t}\right)$ and cumulative distribution $\Phi\left(\boldsymbol{x}_{\boldsymbol{t}}^{\prime} \widehat{\omega}_{k t}\right)$ functions of each household's probability to acquire food within each of the food items. These parameters are applied in the

\footnotetext{
${ }^{41}$ The mixed demand model also includes a specification for the quantity of market goods $\left(x_{i}\right)$, which is not elaborated here as the main purpose is to estimate the virtual prices, as opposed to the complete parameters of the demand system. For more information, please refer to Moschini and Rizzi (2007).
} 
estimation of the normalized quadratic mixed demand parameters using

$$
w_{k}^{*}=\Phi\left(\boldsymbol{x}_{\boldsymbol{t}}^{\prime} \widehat{\omega}_{k t}\right) w_{k}+\varphi_{k} \phi\left(\boldsymbol{x}_{\boldsymbol{t}}^{\prime} \widehat{\omega}_{k t}\right)
$$

As is normal with the application of Shonkwiler and Yen's two step procedure, the system is estimated with the full number of commodities included rather than dropping one equation at the estimation stage (Yen, Kan, \& Su, 2002).

Accordingly, virtual prices for the 4 commodities distributed through the PDS are estimated through a demand system with a total of 8 items is estimated with four PDS food commodities $(k, s=1, \ldots, 4)$ and four free market equivalents $(i, j=1, \ldots, 4)$. These are PDS rice, PDS wheat flour, PDS vegetable oil, PDS sugar, market rice, market wheat flour, market vegetable oil and market sugar ${ }^{42}$. Virtual prices for food items acquired through the PDS estimated in (4) are presented in Table 3 below.

\section{Table 3: Official, Virtual and Market Prices of the PDS Food Basket}

\begin{tabular}{lccc} 
& $\begin{array}{c}\text { Official Price } \\
\text { (Dinar/kg) }\end{array}$ & $\begin{array}{c}\text { Virtual Price } \\
\text { (Dinar/kg) }\end{array}$ & $\begin{array}{c}\text { Unit Values of Market } \\
\text { Equivalent (Dinar/kg) }\end{array}$ \\
\cline { 2 - 4 } Rice & 10 & 65 & 1603 \\
Wheat Flour & 6 & 93 & 895 \\
Vegetable Oil & 6.67 & 11 & 2622 \\
Sugar & 12 & 40 & 1417 \\
\hline
\end{tabular}

Source: Own calculation using IHSES 2012

While significant differences are observed between virtual prices and official prices, these differences are generally smaller than the

\footnotetext{
42 The estimation of the system of equations is estimated using Stata's NLSUR function evaluator program. The main mixed demand model outputs are presented in Appendix 4C.
} 
difference observed between the virtual prices and the prices of free market equivalents. For example, the virtual price for rice is 6.5 times higher than the official price for rice, though this is approximately 25 times less than the observed unit values for its free market equivalents. Similarly, virtual price for wheat flour is 15.5 times higher than the official price for wheat flour, approximately 10 times less than the observed unit values for its free market equivalents. The virtual price for vegetable oil is only 1.6 times the official price for vegetable oil acquired through the PDS, though nearly 240 times less than its free market equivalent. The virtual price for sugar is 3.3 times the official price for PDS sugar, which is approximately 35 times less than its free market equivalent.

Given that virtual prices reflect price levels that result in the observed consumer demand, the virtual prices in Table 3 confirm that the PDS subsidies distort upwards the consumption of the PDS goods, significantly for wheat flour, rice and sugar, and to a far greater extent for vegetable oil. In the estimation of the food demand system for Iraq, PDS food commodities are valued at their virtual prices with budget shares and expenditure adjusted accordingly.

Food Demand system specification

Following the estimation of the virtual prices, the food demand system estimation proceeds assuming a three stage budgeting process whereby households first allocate expenditures between food and non-food groups, followed by allocations between 8 food groups in the second stage, which are further disaggregated into 42 subgroups in the third stage, with each group containing between 3 and 7 sub groups. The food groups are: (i) Cereals including cereal products such as bread, (ii) Vegetables \& Pulses including vegetable products such as canned vegetables, (iii) Fruits including preserved fruits, (iv) 
Oils \& Fats, (v) Fish, Meat \& Eggs, (vi) Milk \& dairy products, (vii) Sugars \& Syrups and (viii) Miscellaneous foods. The composition of these groups is illustrated in Figure 1 below.

Figure 1: Composition of food groups and subgroups

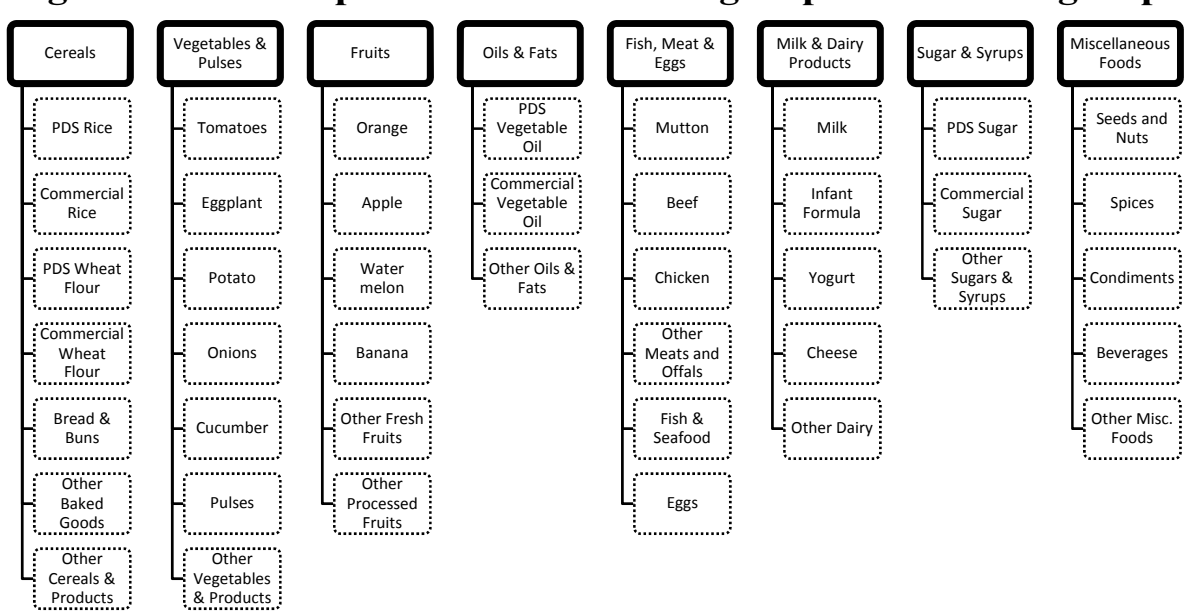

First Budgeting Stage: Working-Leser Model

The parameters from the first budgeting stage are estimated using the Working-Leser model, specified as:

$w_{t}=\alpha_{0}+\beta_{1} \ln P_{t}+\beta_{2} \ln M_{t}+\beta_{3} \ln \left(M_{t}\right)^{2}+\sum_{4}^{n} \boldsymbol{\beta}_{n} \mathbf{z}_{\mathrm{t}}+e_{t}$ 
Where $w_{t}$ is the food budget share, $P_{i}$ is the Stone price index ${ }^{43}$ for food prices paid by the $\mathrm{t}^{\text {th }}$ household, $M_{t}$ is total per capita consumption expenditures including both food and non-food items and $\mathbf{Z}_{\mathbf{t}}$ represents a vector of household characteristics - namely household size and locality type (urban/rural) - and $\beta_{1}$ through $\beta_{n}$ are parameters to be estimated.

Using the parameters from (7), expenditure $(\eta)$ and uncompensated own price elasticities ${ }^{44}\left(e_{i}\right)$ are calculated as:

$$
\eta=1+\left(\frac{\beta_{2}+2 \beta_{3} \ln (M)}{\widehat{w}}\right)
$$

and

$$
e_{f}=-1+\left(\frac{\beta_{1}}{\widehat{w}}\right)
$$

while, by the slutsky equation, the compensated own price elasticities can be calculated as $e_{f}^{c}=e_{f}+\eta \widehat{w}$.

Second and Third Budgeting Stages - QUAIDS model

The general specification of the QUAIDS model (Banks, Blundell, \& Lewbel, 1997) applied in the second budgeting stage is:

$$
w_{i}=\alpha_{i}+\sum_{j=1}^{K} \gamma_{i j} \ln p_{j}+\beta_{i} \ln \left\{\frac{m}{P(\boldsymbol{p})}\right\}+\frac{\lambda_{i}}{b(\boldsymbol{p})}\left[\ln \left\{\frac{m}{P(\boldsymbol{p})}\right\}\right]^{2}
$$

${ }^{43} P_{i}=\sum_{i} w_{i} \ln \left(p_{i}\right)$

${ }^{44}$ The subscript denoting the $\mathrm{t}^{\text {th }}$ household is dropped for elasticities here and elsewhere in the paper as elasticities are estimated at sample means. 
Where, $w_{i}$ is the budget share if the $\mathrm{i}^{\text {th }}$ food group, $p_{j}$ is the price if the $j^{\text {th }}$ food group, including PDS commodities valued at virtual prices as defined in (4), $m$ is total expenditure on items in the demand system and $\boldsymbol{p}$ is the vector of all prices. And where, $b(\boldsymbol{p})$ is the CobbDouglas price aggregator defined as:

$$
b(\boldsymbol{p}) \equiv \prod_{i=1}^{K} p_{i}^{\beta_{i}}
$$

and the price index $\ln P(\boldsymbol{p})$ is defined as:

$$
\ln P(\boldsymbol{p}) \equiv \alpha_{0}+\sum_{i=1}^{K} \alpha_{i} \ln p_{i+} \frac{1}{2} \sum_{i=1}^{K} \sum_{i=j}^{K} \gamma_{i j} \ln p_{i} \ln p_{j}
$$

where $\alpha_{0}$ is set at 2.4 - which is just below the average $\ln (m)$ for the poorest decile following Deaton and Muellbauer's suggestion (1980). The model allows the imposition of symmetry and homogeneity constraints such that $\sum_{i} w_{i}=1, \sum_{i=1}^{K} \alpha_{i}=1, \sum_{i=1}^{K} \beta_{i}=0, \sum_{i=1}^{K} \lambda_{i}=$ $0, \sum_{i=1}^{K} \gamma_{i j}=0 \forall j, \sum_{j=1}^{K} \gamma_{i j}=0 \forall j$ and $\gamma_{i j}=\gamma_{j i}$.

The QUAIDS model specified in (10) is adapted to account for demographic variables (household size and locality types) as well as censoring of the data due to non-acquisition of specific food items during the survey reference period.

To account for demographics based demand shifts, this paper follows the demographic scaling approach proposed by Ray (1983) and operationalized by Poi (2012). This approach scales $b(\boldsymbol{p})$ by a function $c(\boldsymbol{p}, \boldsymbol{z})$ which is defined as

$$
c(\boldsymbol{p}, \mathbf{z})=\prod_{j=1}^{K} p_{j}^{\zeta_{j} \mathbf{z}}
$$


where $\mathbf{z}$ is the vector of demographic variables and $\zeta$ is a $k \mathrm{x} i$ matrix of parameters to be estimated to the $k^{\text {th }}$ demographic variable and $i^{\text {th }}$ good. In addition, total expenditure $m$ is scaled by the linear function $\bar{m}_{0}(\mathbf{z})$, specified as

$$
\bar{m}_{0}(\boldsymbol{z})=1+\boldsymbol{\rho}^{\prime} \boldsymbol{z}
$$

where $\boldsymbol{\rho}$ is a $1 \times k$ matrix of estimated parameters to the $k^{\text {th }}$ demographic variable. As in the first budgeting stage Working Leser model, the second and third stage models include household size and locality type (urban/rural), with the exception of the third stage models for vegetables and fruits, which were also augmented by dummy variables for three out of the four quarters of the year to account for seasonality.

Censoring due to zero acquisition of specific food items in the survey data is addressed using Shonkwiler and Yen's (1999) two step procedure as described in (6). This treatment has been applied within the framework of the QUAIDS model by Ecker and Qaim (2011) and Lambert et al (2006). Accordingly, the final model is specified as

$$
\begin{aligned}
w_{i}^{*}=\Phi\left(\boldsymbol{x}_{\boldsymbol{t}}^{\prime} \widehat{\omega}_{i t}\right) & {\left[\alpha_{i}+\sum_{j=1}^{K} \gamma_{i j} \ln p_{j}+\left(\beta_{i}+\boldsymbol{\zeta}^{\prime} \mathbf{z}\right) \ln \left\{\frac{m}{\bar{m}_{0}(\mathbf{z}) P(\boldsymbol{p})}\right\}\right.} \\
& \left.+\frac{\lambda_{i}}{b(\boldsymbol{p}) c(\boldsymbol{p}, \mathbf{z})}\left[\ln \left\{\frac{m}{\bar{m}_{0}(\mathbf{z}) P(\boldsymbol{p})}\right\}\right]^{2}\right]+\varphi_{i} \phi\left(\boldsymbol{x}_{\boldsymbol{t}}^{\prime} \widehat{\omega}_{i t}\right)
\end{aligned}
$$

where $\alpha_{i}, \gamma_{i j}, \beta_{i}, \lambda_{i}, \zeta_{i}, \rho_{k}$ and $\varphi_{i}$ are parameters to be estimated. It has been shown that with this treatment of censoring in the data, the system of equations should be estimated using the full set of equations rather than the usual approach of dropping one equation and estimating its parameters through the adding up and homogeneity constraints (Yen, Kan, \& Su, 2002). Therefore, the estimation of the system of equations is applied for all equations simultaneously, while 
maintaining homogeneity and symmetry constraints $\left(\sum_{i=1}^{K} \gamma_{i j}=\right.$ $0 \forall j, \sum_{j=1}^{K} \gamma_{i j}=0 \forall j, \gamma_{i j}=\gamma_{j i}$ and $\left.\sum_{i=1}^{K} \zeta_{i}=0\right)$.

Following Poi (2012) and Ecker \& Qaim (2011) in their accounting for demographic scaling and censoring respectively, the conditional expenditure elasticity for the $\mathrm{i}^{\text {th }}$ food group or subgroup $\left(\varepsilon_{i}\right)$ is calculated as

$$
\varepsilon_{i}=1+\frac{\mu_{i}}{w_{i}^{*}}
$$

where $\mu_{i}$ is the derivative of (15) with respect to $\ln (\mathrm{m})$ and is calculated as

$$
\mu_{i}=\Phi\left(\boldsymbol{x}_{\boldsymbol{t}}^{\prime} \widehat{\omega}_{i t}\right)\left(\beta_{i}+\boldsymbol{\zeta}^{\prime} \boldsymbol{z}+\frac{2 \lambda_{i}}{b(p) c(\boldsymbol{p}, \boldsymbol{z})} \ln \left[\frac{m}{a(p) \bar{m}_{0}(\mathbf{z})}\right]\right)
$$

The conditional uncompensated price elasticities $\left(\varepsilon_{i j}\right)$ are calculated as

$$
\varepsilon_{i j}=\frac{\mu_{i j}}{w_{i}{ }^{*}}-\delta_{i j}
$$

where $\delta_{i j}$ is the Kronecker delta taking the value 1 when $i=j$ and 0 otherwise and $\mu_{i j}$ is the derivative of (15) with respect to $p_{j}$, calculated as

$$
\begin{array}{r}
\mu_{i j}=\Phi\left(\boldsymbol{x}_{\boldsymbol{t}}^{\prime} \widehat{\omega}_{i t}\right)\left(\gamma_{i j}-\mu_{i} *\left(\alpha_{i}+\sum_{j=1}^{K} \gamma_{i j} \ln p_{j}\right)\right. \\
\left.-\frac{\lambda_{i}\left(\beta_{j}+\zeta^{\prime} \mathbf{z}\right)}{b(p) c(\boldsymbol{p}, \boldsymbol{z})} \ln \left[\frac{m}{a(p) \bar{m}_{0}(\mathbf{z})}\right]^{2}\right)
\end{array}
$$


With the conditional expenditure and uncompensated price elasticities at hand, conditional compensated price elasticities are calculated as

$$
\varepsilon_{i j}^{c}=\frac{\mu_{i j}}{w_{i}^{*}}+\varepsilon_{i} w_{j}^{*}
$$

Finally, Edgerton's (1997) approach to produce unconditional elasticities in a multi stage budgeting system is applied such that the unconditional expenditure $\left(E_{i}\right)$, compensated $\left(E_{i j}^{c}\right)$ and uncompensated price elasticities $\left(E_{i j}\right)$ for the second stage food groups are calculated as

$$
E_{i}=\eta \varepsilon_{i}
$$

and

$$
E_{i j}^{c}=\delta_{f n} \varepsilon_{i j}^{c}+\varepsilon_{i} w_{j} e_{f}^{c}
$$

and

$$
E_{i j}=\delta_{f n} \varepsilon_{i j}+\varepsilon_{i} w_{j}\left[\delta_{f n}+e_{f}\right]
$$

where $\delta_{f n}$ is Kronecker's delta, which, in this context, takes only the value 1 as the both the first and second budgeting stages models demand for food only. This is extended to the third stage where the unconditional expenditure $\left(\tilde{E}_{i}\right)$ and unconditional uncompensated price elasticities $\left(\tilde{E}_{i j}\right)$ for the $i^{\text {th }}$ within food group $a$ and the $j^{\text {th }}$ subgroup within food group $b$ are calculated as

$$
\tilde{E}_{i}=\varepsilon_{i} E_{i}
$$

and

$$
\tilde{E}_{i j}=\delta_{a b} \varepsilon_{[a] i j}^{c}+w_{[b] j} \varepsilon_{[a] i} E_{[a][b]}
$$


where $\delta_{a b}$ is Kronecker's delta taking the value of 1 for within group elasticities and zero otherwise. By Eq. 25, between group cross price elasticities (i.e. where $a \neq b$ ) are estimated through expenditure effects.

\section{Nutrient Elasticities}

The estimation of nutrient expenditure and price elasticities applied here follows the approach proposed by Huang (1996), also applied by Widarjono (2012) and Zheng and Henneberry (2012). In this approach, the $\mathrm{k}^{\text {th }}$ nutrient price elasticity $\left(\pi_{k j}\right)$ represents the nutrient-share weighted average of all own and cross price elasticities with respect to $\mathrm{j}^{\text {th }}$ food price. Similarly, the $\mathrm{k}^{\text {th }}$ nutrient expenditure elasticity $\left(\rho_{k}\right)$ is the nutrient-share weighted average of expenditure elasticities. Using the previously specified elasticities, the $\mathrm{k}^{\text {th }}$ nutrient price and expenditure elasticities are specified as

$$
\pi_{k j}=\sum_{i} E_{i j} a_{k i} q_{i} / \Phi_{k}
$$

and

$$
\rho_{k}=\sum_{i} E_{i} a_{k i} q_{i} / \Phi_{k}
$$

where $a_{k i} q_{i}$ is the $\mathrm{k}^{\text {th }}$ nutrient acquired from the ith food and $\Phi_{k}$ is the total $\mathrm{k}^{\text {th }}$ nutrient acquired from all foods in the demand system. For subgroups nutrient elasticities, $E_{i}$ and $E_{i j}$ are replaced with $\tilde{E}_{i}$ and $\tilde{E}_{i j}$. The nutrients considered in this study are calories, protein, carbohydrates, fats, iron, zinc, folate, vitamin A and vitamin B12. 


\subsection{Results: Food and Nutrient Demand Elasticities in Iraq}

Expenditure and price elasticity of demand for food, estimated according to the methods described in Section 3.3, are presented and discussed below, including the results from the first, second and third budgeting stages. Furthermore, elasticities of demand for nine essential macro and micronutrients are presented and discussed. Where possible, implications of estimated demand elasticities on the expected consumption responses to the elimination of PDS food subsidies are discussed.

First Budgeting Stage Food Demand Elasticities

The parameters of the first-stage Working-Leser model is estimated by Ordinary Least Squares regression ${ }^{45}$ according to Eq. 7. These parameters are applied in estimating overall expenditure and price elasticities for food as set out in Eqs. 8 and 9. These are presented and discussed below.

\footnotetext{
${ }^{45}$ Main model outputs are presented in Appendix 4A
} 
Table 4: First stage food expenditure and price elasticities*

\begin{tabular}{lccc} 
& $\begin{array}{c}\text { Expenditure } \\
\text { Elasticity }(\eta)\end{array}$ & $\begin{array}{c}\text { Uncompensated } \\
\text { own-price elasticity }\left(e_{f}\right)\end{array}$ & $\begin{array}{c}\text { Compensated } \\
\text { own-price } \\
\text { elasticity }\left(e_{f}^{c}\right)\end{array}$ \\
\cline { 2 - 4 } Decile 1 & 0.825 & -0.759 & -0.303 \\
Decile 2 & 0.813 & -0.741 & -0.267 \\
Decile 3 & 0.806 & -0.732 & -0.250 \\
Decile 4 & 0.799 & -0.723 & -0.234 \\
Decile 5 & 0.792 & -0.713 & -0.218 \\
Decile 6 & 0.786 & -0.705 & -0.206 \\
Decile 7 & 0.781 & -0.698 & -0.195 \\
Decile 8 & 0.774 & -0.689 & -0.182 \\
Decile 9 & 0.763 & -0.673 & -0.161 \\
Decile 10 & 0.737 & -0.638 & -0.120 \\
National & 0.790 & -0.711 & -0.215 \\
\hline Source: & & & All
\end{tabular}

Source: Own calculation using IHSES 2012. ${ }^{*}$ All elasticities are significant at the 0.01 level.

Table 4 lists the expenditure and price elasticity for food demand national and for each decile. The national average expenditure elasticity for food overall is 0.79 and the uncompensated own price elasticity is -0.711 . This means that a 1 percent increase in total consumption expenditure increases demand for food by 0.79 percent while a 1 percent increase in the price of food reduces demand for food by 0.711 percent.

All elasticities of demand for food are decreasing in income, confirming the often made assertion that the poorest members of society are most affected by food price increases. However, with expenditure elasticities being highest for the poorest members of Iraqi society, an increase in income or expenditure will result in higher gains in food consumption for members of the poorest decile than for wealthier Iraqis.

As evident in Table 5, the expenditure elasticity produced by the Working-Leser model applied in this paper is similar to those estimated using aggregate data from the International Comparison 
Program (ICP) and reported by Gao (2011) and Muhammed et al. (2011) at 0.80 and 0.779 respectively.

Table 5: Reported Expenditure and Price elasticities for Iraq

\begin{tabular}{lccc}
\multicolumn{1}{c}{ Source } & $\begin{array}{c}\text { Expenditure } \\
\text { Elasticity }(\eta)\end{array}$ & $\begin{array}{c}\text { Uncompensated } \\
\text { own-price elasticity } \\
\left(e_{f}\right)\end{array}$ & $\begin{array}{c}\text { Compensated } \\
\text { own-price } \\
\text { elasticity }\left(e_{f}^{c}\right)\end{array}$ \\
\hline $\begin{array}{l}\text { Gao }(2011) \\
\text { Muhammad et al. }\end{array}$ & 0.80 & -0.62 & -0.34 \\
$(2011)^{*}$ & 0.779 & -0.734 & -0.354 \\
\hline
\end{tabular}

* Estimates by Muhammad et al. (2011) are for Food, beverages, \& tobacco

The compensated price elasticity estimated by the Working-Leser model applied in this paper is lower than the other estimates whereas uncompensated price elasticities estimated in this paper $(-0.711)$ is similar to that estimated by Muhammad et al. (-0.734) and higher than that estimated by Gao (-0.62). It should be noted that comparability between the elasticities estimated in this report and those reported by Gao and Muhammad et al. is somewhat limited by differences in methods. Gao reports Slutsky and Cournot elasticities, which are presented here as compensated and uncompensated respectively, while Muhammad et al. reports Frisch and Cournot elasticities, which are presented here as compensated and uncompensated respectively. Although the reported uncompensated elasticities are comparable in method and interpretation, there are some differences in the compensated elasticities. The Frisch compensated elasticity, reported by Muhammad et al., compensates consumers following a price change by holding marginal utility of income constant and the Slutsky compensated elasticity, reported by Gao, compensates consumers following a price change by holding real income constant (Regmi \& Seale, 2010). In contrast, the Hicksian compensated elasticity, estimated in this paper, compensates consumers following a price change by holding utility constant. 
The system of nonlinear equations constituting the second-stage QUAIDS model is estimated system of equations by iterative feasible generalized nonlinear least squares ${ }^{46}$. Given the treatment for censoring in the data, as specified in Eqs. 6 and 15, the full system is estimated without enforcing additivity constraints as recommended by Yen et al. (2002). Accordingly, the system includes 8 equations, estimating a total of 76 parameters. Following Deaton and Muellbauer's recommendation (1980), the $\boldsymbol{\alpha}_{\mathbf{0}}$ parameter, see Eq. 12, is set to an arbitrary low value, which in this paper is set equal to 2.4, which is just below the average $\ln (\boldsymbol{m})$ for the poorest decile. The parameters estimated through the system of equations are presented in Appendix 4B, where it can be seen that the quadratic coefficients $\left(\boldsymbol{\lambda}_{\boldsymbol{i}}\right)$ are significant for all but two food groups - Fish, Meat \& Eggs and Miscellaneous Foods.

Table 6 presents the unconditional price and expenditure demand elasticity matrix for the eight food groups, estimated at sample means. Own price elasticities are indicated in bold text on the diagonal and cross price elasticities are off diagonal. Expenditure elasticities are listed in the last column.

\footnotetext{
${ }^{46}$ Estimation was performed in Stata 13.1 using the function evaluator program version of the built-in non-linear seemingly unrelated regression (n/sur) command.
} 
Table 6: Stage 2 - Unconditional Expenditure $\left(E_{i}\right)$ and Uncompensated Price Elasticities $\left(E_{i j}\right)$

\begin{tabular}{|c|c|c|c|c|c|c|c|c|c|}
\hline & & & & Price & ities & & & & \\
\hline & $\begin{array}{c}\text { Group 1: } \\
\text { Cereals \& } \\
\text { Cereal } \\
\text { Products }\end{array}$ & $\begin{array}{l}\text { Group 2: } \\
\text { Vegetables } \\
\text { \& Pulses }\end{array}$ & $\begin{array}{l}\text { Group 3: } \\
\text { Fruits \& } \\
\text { Fruit } \\
\text { Products }\end{array}$ & $\begin{array}{l}\text { Group 4: } \\
\text { Oils \& Fats }\end{array}$ & $\begin{array}{l}\text { Group 5: } \\
\text { Fish, Meat } \\
\text { \& Eggs }\end{array}$ & $\begin{array}{l}\text { Group 6: } \\
\text { Milk \& } \\
\text { Dairy } \\
\text { Products }\end{array}$ & $\begin{array}{c}\text { Group 7: } \\
\text { Sugars \& } \\
\text { Syrups }\end{array}$ & $\begin{array}{l}\text { Group 8: } \\
\text { Misc. } \\
\text { Foods }\end{array}$ & $\begin{array}{l}\text { Expend. } \\
\text { Elasticity }\end{array}$ \\
\hline Group 1 & $-0.652^{* * *}$ & $-0.139^{* *}$ & $0.044^{* *}$ & $0.016^{* *}$ & $0.075^{* *}$ & $0.032^{* *}$ & $0.017^{* *}$ & $0.023^{* *}$ & $0.647^{* *}$ \\
\hline Group 2 & $-0.045^{* *}$ & $-0.686^{* *}$ & $0.026^{* *}$ & $0.008^{* *}$ & -0.001 & $0.035^{* *}$ & $0.006^{* *}$ & $0.031^{* *}$ & $0.694^{* *}$ \\
\hline Group 3 & $0.056^{* *}$ & 0.000 & $-0.900^{* * *}$ & $0.011^{* *}$ & $0.105^{* *}$ & $-0.019^{* *}$ & $0.014^{* *}$ & $-0.028^{* *}$ & $0.858^{* *}$ \\
\hline Group 4 & $0.159^{* *}$ & $-0.124^{* *}$ & $0.043^{* *}$ & $-0.736^{* *}$ & 0.071 & $-0.051^{* *}$ & $-0.021^{*}$ & $-0.026^{* *}$ & $0.758^{* *}$ \\
\hline Group 5 & $0.015^{* *}$ & $-0.061^{* *}$ & $0.034^{* *}$ & $0.005^{* *}$ & $-0.786^{* *}$ & $-0.011^{* *}$ & $0.013^{* *}$ & $-0.006^{* *}$ & $0.890^{* *}$ \\
\hline Group 6 & $0.058^{* *}$ & $0.034^{* *}$ & 0.001 & $0.012^{* *}$ & -0.001 & $-0.881^{* * *}$ & $0.013^{* *}$ & -0.002 & $0.860^{* *}$ \\
\hline Group 7 & $0.099^{* *}$ & $-0.092^{* *}$ & $0.038^{* *}$ & $-0.011^{*}$ & $0.119^{* *}$ & $-0.024^{*}$ & $-0.808^{* *}$ & $-0.017^{* *}$ & $0.773^{* *}$ \\
\hline Group 8 & $0.112^{* *}$ & $0.094^{* *}$ & $-0.032^{* *}$ & $0.019^{* *}$ & 0.004 & $-0.02^{*}$ & $0.017^{* *}$ & $-0.931^{* *}$ & $0.828^{* *}$ \\
\hline
\end{tabular}

Source: Own calculation using IHSES 2012. The elasticities represent the change in the demand for [row] given the change in the price of [column]. Statistical significance calculated using standard errors estimated by the delta method. ${ }^{* *}=$ $99 \% ;{ }^{*}=95 \%$

As evident in Table 6, all 8 food groups are neither price nor expenditure elastic. Expenditure elasticities estimated in this paper are generally higher than those reported by Muhammad et al. (2011). Using data from the International Comparison Program (ICP), Muhammad et al. estimate a single model for 114 countries and produce point estimates for individual countries. They estimate an unconditional expenditure elasticity of 0.519 for Cereals, 0.771 for Meats, 0.653 for Fish, 0.798 for Dairy, 0.615 for Fruits and Vegetables combined and 1.268 for "other food".

Considering the sign of cross price elasticities allows the identification of substitutes and complements reflecting the preferences of the average Iraqi household. Negative uncompensated cross price elasticities represent gross complements and positive uncompensated cross price elasticities represent gross substitutes. For example, all food groups except vegetables are gross substitutes to Cereals \& Cereal Products while the Vegetables and Pulses food group are gross complements to Cereals \& Cereal Products. 
Similarly, all food groups except Cereals \& Cereal Products are gross substitutes to the Vegetables and Pulses food group.

Limited asymmetry in the unconditional cross price elasticities can be observed. For example, the unconditional elasticities suggest that the Vegetables and Pulses food group is a gross substitute for the Oils and Fats food group while the latter is a gross complement to the former. This, however, is a feature of the unconditional uncompensated elasticities while the matrix of conditional compensated elasticities is symmetric. While symmetry is imposed in the estimation of the second and third stages of the demand system, which produce the conditional elasticities, Edgerton's approach applied in the present paper to estimate unconditional elasticities does not necessarily maintain symmetry in the matrix of unconditional elasticities (Edgerton, 1997).

Generally, food groups that contain PDS food items (Cereals \& Cereal Products, Oils \& Fats and Sugars \& Syrups) possess substitutes among the remaining food groups. Accordingly, in the context of PDS reform, the negative own price elasticities for the PDS food groups and the positive off-diagonal cross price elasticities 47 implies that households will generally be able to compensate for the loss of PDS subsidies by increasing consumption of other food groups.

\section{Third Budgeting Stage Food Demand Elasticities}

As with the second budgeting stage, the third budgeting stage QUAIDS model accounts for censoring in the data and applies demographic scaling to account for household size and location of residence and - for vegetables and fruits - seasonality. Eight separate models, fitted as specified in Eq. (15), range from 3 to 7 subgroups

${ }^{47}$ Looking down the column of the PDS food groups 
(as described in Figure 1) are computed simultaneously for all subgroups without enforcing additivity constraints as recommended by Yen et al. (2002). Accordingly, the third stage system of equations includes a total of 42 subgroups within the 8 food groups, estimating a total of 389 parameters. The $\boldsymbol{\alpha}_{\mathbf{0}}$ parameter for each of the eight models is set equal to the $25^{\text {th }}$ percentile of the logtransformed total expenditure on food within each food group. The main model results are presented in Appendix 4B. Table 7 lists own price and expenditure elasticity for the 42 subgroups included in the stage 3 model while the complete matrix of expenditure and own and cross price elasticities can be viewed in Appendix 4D.

The subgroup elasticities listed in Table 7 reveal additional details on Iraq consumer preferences over food commodities and differences across the wealth distribution. In comparison with the overall expenditure elasticity of demand for food (Table 4) which is generally decreasing in total expenditure, the trend in expenditure elasticity of demand for food groups and subgroups reflects varying preferences across expenditure deciles. Expenditure elasticities for the Cereals food group is lower for the poorest decile compared with the wealthiest decile. The same is true for the Oils and Fats and the Sugars and Syrups food groups. Noting that these three food groups contain PDS food items, this trend reflects the fact that the food items contained within these food groups are greater necessities for the poorer segments of Iraqi society. In contrast, expenditure elasticities for the remaining food groups are generally flat or decreasing in total expenditure.

It can also be observed that, for some food groups, the population mean expenditure elasticity falls outside the range set by the elasticities for the poorest and wealthiest deciles. For example, the population mean expenditure elasticity for Fruits is lower than both elasticities for the poorest and wealthiest deciles. This is a reflection of a pronounced non-linear U-shaped curve where the expenditure elasticities for Fruits are lower for the middle deciles than those at the extremes of the total expenditure distribution. 
In addition, it is apparent from the subgroup level elasticities that - on average - PDS Rice and commercial Wheat Flour are considered inferior goods $\left(\tilde{E}_{i}<0\right)$ as the negative expenditure elasticities for these two subgroups indicate decreasing desirability as total expenditure increases.

Table 7: Unconditional Expenditure and Uncompensated ownprice elasticities of food demand at population means and for the poorest and richest deciles

Expenditure Elasticities Own Price Elasticities

\begin{tabular}{|c|c|c|c|c|c|c|}
\hline & Mean & Poorest & Richest & Mean & Poorest & Richest \\
\hline Cereals & $0.647^{* *}$ & $0.287^{* * *}$ & $\mathbf{0 . 7 5 9}^{* *}$ & $-0.652^{* * *}$ & $-0.375^{* *}$ & $-0.503^{* * *}$ \\
\hline PDS Rice & $-0.272^{* *}$ & -0.02 & $-0.515^{* *}$ & $0.454^{* *}$ & $-0.363^{* *}$ & $1.033^{* *}$ \\
\hline $\begin{array}{l}\text { Commercial } \\
\text { Rice } \\
\text { PDS Wheat }\end{array}$ & $0.847^{* *}$ & $0.402^{* *}$ & $0.950^{* *}$ & $-1.198^{* *}$ & $-2.108^{* *}$ & $-0.995^{* *}$ \\
\hline $\begin{array}{l}\text { Flour } \\
\text { Commercial }\end{array}$ & $0.276^{* *}$ & $0.173^{* *}$ & 0.024 & $-0.312^{* *}$ & 0.120 & $-0.588^{* *}$ \\
\hline Wheat Flour & $-0.513^{* *}$ & $-0.434^{* *}$ & $0.213^{* *}$ & $-1.033^{* *}$ & -0.344 & $-1.197^{* *}$ \\
\hline $\begin{array}{l}\text { Bread \& Buns } \\
\text { Other Baked }\end{array}$ & $0.793^{* *}$ & $0.332^{* *}$ & $0.939^{* *}$ & $-1.218^{* *}$ & $-0.863^{* *}$ & $-0.849^{* *}$ \\
\hline $\begin{array}{l}\text { Goods } \\
\text { Other Cereals \& }\end{array}$ & $0.78^{* *}$ & $0.360^{* *}$ & $0.895^{* *}$ & $-0.655^{* *}$ & $-0.311^{*}$ & $-0.831^{* *}$ \\
\hline Cereal Products & $1.208^{* *}$ & $0.659^{* *}$ & $1.222^{* *}$ & $-0.787^{* *}$ & $-0.716^{* *}$ & $-0.980^{* *}$ \\
\hline $\begin{array}{l}\text { Vegetables \& } \\
\text { Pulses }\end{array}$ & $0.858^{* *}$ & \multicolumn{4}{|c|}{ Vegetables \& } & $-0.758^{* * *}$ \\
\hline Tomatoes & $0.690^{* *}$ & $0.822^{* *}$ & $0.514^{* *}$ & $-0.929^{* *}$ & $-0.653^{* *}$ & $-2.159^{* *}$ \\
\hline Eggplant & $0.673^{* *}$ & $0.848^{* *}$ & $0.497^{* *}$ & $-0.469^{* *}$ & $-0.622^{* *}$ & 0.136 \\
\hline Potato & $0.679^{* *}$ & $0.842^{* *}$ & $0.500^{* *}$ & $-0.698^{* *}$ & $-0.698^{* *}$ & $-0.734^{* *}$ \\
\hline Onion & $0.665^{* *}$ & $0.829^{* *}$ & $0.499^{* *}$ & $-0.502^{* *}$ & $-0.656^{* *}$ & 0.067 \\
\hline Cucumber & $0.666^{* *}$ & $0.836^{* *}$ & $0.499^{* *}$ & $-0.574^{* *}$ & $-0.793^{* *}$ & 0.219 \\
\hline Pulses & $0.650^{* *}$ & $0.779^{* *}$ & $0.496^{* *}$ & $-0.862^{* *}$ & $-0.842^{* *}$ & $-0.999^{* *}$ \\
\hline \multirow{2}{*}{\multicolumn{7}{|c|}{$\begin{array}{l}\text { Other } \\
\text { Vegetables \& }\end{array}$}} \\
\hline & & & & & & \\
\hline Veg. Products & $0.728^{* *}$ & $0.906^{* *}$ & $0.536^{* *}$ & $-0.640^{* *}$ & $-0.760^{* *}$ & $-0.457^{* *}$ \\
\hline Fruits & $0.758^{* *}$ & $0.835^{* *}$ & $0.836^{* *}$ & $-0.900^{* * *}$ & $-0.848^{* *}$ & $-0.862^{* *}$ \\
\hline Orange & $0.670^{* *}$ & $0.669^{* *}$ & $0.644^{* *}$ & $-0.960^{* *}$ & $-0.760^{* *}$ & $-1.211^{* *}$ \\
\hline Apple & $0.817^{* *}$ & $0.795^{* *}$ & $0.797^{* *}$ & $-0.311^{* *}$ & $-0.622^{* *}$ & 0.091 \\
\hline Water melon & $0.960^{* *}$ & $0.944^{* *}$ & $0.933^{* *}$ & $-0.816^{* *}$ & $-0.855^{* *}$ & $-0.740^{* *}$ \\
\hline Banana & $0.869^{* *}$ & $0.831^{* *}$ & $0.861^{* *}$ & $-0.307^{* *}$ & $-0.794^{* *}$ & 0.207 \\
\hline Other Fresh & & & & & & \\
\hline $\begin{array}{l}\text { Fruit } \\
\text { Other Processed }\end{array}$ & $0.952^{* *}$ & $0.923^{* *}$ & $0.932^{* *}$ & $-1.357^{* *}$ & $-1.101^{* *}$ & $-1.681^{* *}$ \\
\hline Fruit & $0.700^{* *}$ & $0.715^{* *}$ & $0.645^{* *}$ & $-1.660^{* *}$ & $-1.245^{* *}$ & $-2.216^{* *}$ \\
\hline
\end{tabular}




\begin{tabular}{|c|c|c|c|c|c|c|}
\hline $\begin{array}{l}\text { Oils \& Fats } \\
\text { PDS Vegetable }\end{array}$ & $0.890^{* *}$ & $0.695^{* *}$ & $0.766^{* *}$ & $-0.736^{* *}$ & $-0.486^{* *}$ & $-0.364^{* *}$ \\
\hline Oil & $0.473^{* *}$ & $0.473^{* *}$ & $0.460^{* *}$ & $-0.664^{* *}$ & $-0.619^{* *}$ & $-0.498^{* *}$ \\
\hline Commercial & & & & & & \\
\hline $\begin{array}{l}\text { Vegetable Oil } \\
\text { Other Fats \& }\end{array}$ & $1.128^{* *}$ & $1.161^{* *}$ & $1.062^{* *}$ & $0.393^{* *}$ & $2.784^{* *}$ & $-0.260^{* *}$ \\
\hline Oils & $1.242^{* *}$ & $1.491^{* *}$ & $1.114^{* *}$ & $-2.223^{* *}$ & $-5.469^{* *}$ & $-1.249^{* *}$ \\
\hline \multicolumn{7}{|l|}{ Fish, Meat \& } \\
\hline Eggs & $0.860^{* *}$ & $0.946^{* *}$ & 0.820 ** & $-0.786^{* *}$ & $-0.798^{* *}$ & $-0.752^{* *}$ \\
\hline Mutton & $1.318^{* *}$ & $1.320^{* *}$ & $1.216^{* *}$ & $-0.832^{* *}$ & $-0.786^{* *}$ & $-0.865^{* *}$ \\
\hline Beef & $1.038^{* *}$ & $1.147^{* *}$ & $0.937^{* *}$ & $-0.998^{* *}$ & $-1.016^{* *}$ & $-0.991^{* *}$ \\
\hline Chicken & $0.780^{* *}$ & $0.888^{* *}$ & $0.661^{* *}$ & $-0.885^{* *}$ & $-0.920^{* *}$ & $-0.856^{* *}$ \\
\hline Other Meats & & & & & & \\
\hline and Offal & $0.710^{* *}$ & $0.855^{* *}$ & $0.575^{* *}$ & $-0.939^{* *}$ & $-1.154^{* *}$ & $-0.909^{* *}$ \\
\hline Fish \& Seafood & $0.813^{* *}$ & $0.910^{* *}$ & $0.726^{* *}$ & $-0.949^{* *}$ & $-0.795^{* *}$ & $-0.971^{* *}$ \\
\hline Eggs & $0.847^{* *}$ & $0.830^{* *}$ & $0.886^{* *}$ & $-0.903^{* *}$ & $-0.924^{* *}$ & $-0.890^{* *}$ \\
\hline \multicolumn{7}{|l|}{ Milk \& Dairy } \\
\hline Products & $0.860^{* *}$ & $0.966^{* *}$ & $0.760^{* *}$ & $-0.881^{* *}$ & $-0.959^{* *}$ & $-1.036^{* *}$ \\
\hline Milk & $1.063^{* *}$ & $1.327^{* *}$ & $0.874^{* *}$ & $-0.940^{* *}$ & $-0.950^{* *}$ & $-0.899^{* *}$ \\
\hline Infant Formula & $1.162^{* *}$ & $1.377^{* *}$ & $0.976^{* *}$ & $-0.983^{* *}$ & $-0.960^{* *}$ & $-1.024^{* *}$ \\
\hline Yogurt & $0.871^{* *}$ & $0.984^{* *}$ & $0.775^{* *}$ & $-0.774^{* *}$ & $-0.853^{* *}$ & $-0.779^{* *}$ \\
\hline Cheese & $0.658^{* *}$ & $0.757^{* *}$ & $0.581^{* *}$ & $-0.868^{* *}$ & $-0.900^{* *}$ & $-0.913^{* *}$ \\
\hline \multicolumn{7}{|l|}{ Other Dairy } \\
\hline Products & $0.971^{* *}$ & $1.025^{* *}$ & $0.886^{* *}$ & $-0.880^{* *}$ & $-0.845^{* *}$ & $-1.007^{* *}$ \\
\hline Sugars \& Syrups & $0.773^{* *}$ & $0.643^{* *}$ & $0.810^{* *}$ & $-0.808^{* * *}$ & $-0.623^{* *}$ & $-0.555^{* *}$ \\
\hline PDS Sugar & $0.160^{* *}$ & $0.201^{* *}$ & $0.225^{* *}$ & $-0.683^{* *}$ & $-0.820^{* *}$ & $-0.591^{* *}$ \\
\hline \multicolumn{7}{|l|}{ Commercial } \\
\hline Sugar & $1.228^{* *}$ & $1.716^{* *}$ & $1.101^{* *}$ & $-1.272^{* *}$ & $-4.220^{* *}$ & $-0.908^{* *}$ \\
\hline Other Sugars \& & & & & & & \\
\hline Syrups & $1.094^{* n}$ & $1.017^{* n}$ & $1.086^{\circ-4}$ & $-0.312^{* n}$ & $1.276^{*-4}$ & $-0.532^{*}$ \\
\hline \multicolumn{7}{|l|}{ Miscellaneous } \\
\hline Foods & $0.828^{* * *}$ & $0.843^{* *}$ & $0.783^{* *}$ & $-0.9311^{* *}$ & $-0.977^{* * *}$ & $-1.054^{* *}$ \\
\hline Seeds and Nuts & $0.889^{* *}$ & $0.972^{* *}$ & $0.771^{* *}$ & $-4.744^{* *}$ & $-7.597^{* *}$ & $-2.491^{* *}$ \\
\hline Spices & $0.730^{* *}$ & $0.705^{* *}$ & $0.741^{* *}$ & $-2.065^{* *}$ & $-2.487^{* *}$ & $-1.495^{* *}$ \\
\hline Condiments & $0.875^{* *}$ & $0.946^{* *}$ & $0.752^{* *}$ & $2.427^{* *}$ & $4.205^{* *}$ & $0.451^{* *}$ \\
\hline Beverages & $0.878^{* *}$ & $0.902^{* *}$ & $0.819^{* *}$ & $-1.217^{* * *}$ & $-0.690^{* *}$ & $-1.307^{* *}$ \\
\hline Other & & & & & & \\
\hline Miscellaneous & $0.867^{* *}$ & $0.964^{* *}$ & $0.756^{* *}$ & $2.849^{* *}$ & $3.168^{* *}$ & $1.318^{* *}$ \\
\hline
\end{tabular}

Source: Own calculation using IHSES 2012. Statistical significance calculated using standard errors estimated by the delta method. ${ }^{* *}=99 \% ;{ }^{*}=95 \%$

For the poorest decile, the expenditure elasticity for PDS Rice (-0.02) is small and not statistically significant, thus indicating that PDS Rice is a necessity for this group. However, for all other deciles, this elasticity is negative and statistically significant, confirming the inferior status of PDS Rice. Commercial Wheat Flour is also found to be an inferior good, not only on average, but also for all deciles save for the wealthiest decile where it is considered a normal good. 
Most of the remaining commodities are normal goods $\left(0<\tilde{E}_{i}<1\right)$ and a minority are considered superior goods $\left(\widetilde{E}_{i}>1\right)$. Within the Oils and Fats food group, the Commercial Vegetable Oil and Other Fats and Oils subgroups are considered superior goods across all deciles whereas the Vegetable Oil subgroup is a normal good for all deciles. The same pattern is observed for the subgroups within the Sugars and Syrups food group where the commercial items are superior and the PDS item is a normal good. None of the subgroups within both the Vegetables and Pulses food group and the Fruits food group are superior goods while Mutton, Beef, Milk and Infant Formula are considered superior goods on average and at least for some of the deciles.

Table 7 also lists own-price elasticities for all food groups and subgroups presented at means for the entire population and for the poorest and wealthiest deciles. Demand for all food groups is decreasing in prices and inelastic $\left(0>E_{i j}>-1\right)$, except for wealthiest decile where the own price elasticity for Milk and Dairy Products and for Miscellaneous Foods are elastic (-1.036 and -1.054 respectively). Interestingly, a few positive price elasticities are listed for individual subgroups. For example, the population mean price elasticity for PDS Rice is estimated at 0.454 , which when considered together with the negative expenditure elasticity confirm the presence of Giffen behavior in relation to PDS Rice. A Giffen good, which is an inferior good with a positively sloping demand curve in relation to its own price, is generally recognized as a plausible exception to the Law of Demand though is very rare to observe in empirical settings (Read, 2013).

While the typical example of a Giffen good is Potato during the 1845 Irish Famine (Read, 2013) efforts to find more contemporary reported examples of Giffen goods in published empirical works produce very little evidence. Nonetheless, one example of such evidence is reported by Jensen and Miller (2008) who detected Giffen behavior in relation to consumption of rice among urban poor households in 
Hunan and Gansu Provinces in China ${ }^{48}$. In addition, Ecker and Matin (2011) reported negative expenditure and positive own price elasticities for Cassava in rural Malawi, although the authors did not explicitly identify the elasticities as a reflection of Giffen behavior and only noted Cassava to be an inferior good in rural areas.

The experimental results from Jensen and Miller (2008) is worthy of additional notice in this context as their experimental design sought to specifically subsidize purchases of primary dietary staples of urban poor households in China - subsidizing the consumption of rice in Hunan Province and the consumption of wheat in Gansu Province. They identify Giffen behavior in relation to the price of rice though not for the poorest or the wealthiest participants. They also fail to detect Giffen behavior in relation to the price of wheat, claiming that sufficient wheat-based substitution opportunities (such as wheat based noodles) mitigated the need to engage in Giffen behavior.

Some similarities can be found with the results presented in Table 7. For example, Giffen behavior is observed for rice, though not for the poorest decile. In addition, Giffen behavior is not detected for wheat flour, whether it is PDS wheat flour or commercial wheat flour. While the own price elasticity for PDS wheat flour is positive, it is also not statistically significant. This echoes Jensen and Miller's results for wheat flour, particularly since we also observe substantial wheat based substitutes such as Commercial Wheat Flour, Bread and Buns and Other Baked Goods with positive cross price elasticities of $0.688,0.299$ and 0.559 respectively ${ }^{49}$.

The findings in this paper in relation to demand for PDS rise also reflect similar findings by Jensen and Miller (2008), particularly the fact that Giffen behavior is not observed among the poorest.

\footnotetext{
${ }^{48}$ It should be noted however that Jensen and Miller's (2008) reported results are estimated using data collected in an experiment designed to experiment explore the responses of poor households in China to changes in the prices of staple food.

${ }^{49}$ Cross price elasticities are listed in the full matrix of elasticities in Appendix 4
} 
In their paper, Jensen and Miller specify factors that influence Giffen behavior: That the consumers be impoverished, but not too impoverished, and that they rely heavily on a staple good with limited substitution possibilities. In their research, they identify an invertedU shaped demand curve with normal demand among the poorest and wealthiest and Giffen behavior for the intermediate group. This is partially confirmed by the results in this paper, as we estimate the own price demand elasticity for PDS rice among the poorest decile is -0.363 , rising to 0.009 among the second poorest decile, 0.158 among the third poorest decile and so on, reaching 1.033 among the wealthiest decile. The main difference being that Giffen behavior is also observed among the wealthiest decile. This may be attributed to differences in the context, as Jensen and Miller's experiment spanned a period of only 5 months whereas the PDS has been ongoing for over 2 decades and is a major source of food, even among the wealthiest Iraqis. The PDS provides 21 percent of the total calories consumed in the wealthiest decile (WFP \& GOI, 2012).

Overall, the listed own price elasticities indicate substantial price responsiveness of demand for subgroups. Price elastic subgroups include Commercial Rice, Wheat Flour and Sugar, Breads and Buns and Other Baked Goods, Other Fresh and Processed Fruits and all subgroups within the Miscellaneous Foods group. Listed in Table 7 are also a few subgroups with positive elasticities other than PDS Rice, including Commercial Vegetable Oil, Condiments and Other Miscellaneous foods. While also an exception to the Law of Demand, empirical examples of positive own price elasticities can be found in the empirical literature such as Ulubasoglu et al. (Ulubasoglu, Mallick, Wadud, Hone, \& Haszler, 2015) who estimate a positive price elasticity for sugar and jam in Australia and Bergtold et al. (Bergtold, Akobundu, \& Peterson, 2004) who estimate a positive price elasticity for sauces and marinades in the United States.

A positive price elasticity for superior goods describes another known exception to the Law of Demand, namely the Veblen effect where consumers demand more of a good with an increase in price as an 
expression of wealth status. However, it is extremely unlikely that this is the case for Commercial Vegetable despite the estimated expenditure elasticity of 1.128 and an own price elasticity of 0.393 . One plausible explanation could be that temporary supply disruptions of PDS Vegetable Oil lead to a simultaneous increase in the price of, and demand for, Commercial Vegetable Oil - manifesting in a positive price elasticity.

Unfortunately, there are no published Marshallian elasticities for Iraq at the level of food subgroup or commodity to compare and verify the estimated elasticities listed in Table 7. The mixed demand elasticities estimated by Krishnan, Olivieri and Ramadan (2017) are not comparable, partially due to the fact that mixed Marshallian elasticities for the rationed goods are not directly comparable to the typical Marshallian elasticities (Moschini \& Rizzi, 2007; Moschini \& Vissa, 1993) and also due to the fact that the free market commodity groups included in the model estimated by Krishnan et al. differ from most of the commodity groups considered in this paper.

However, given the similarity in the commercial rice commodity group included in the model estimated by Krishnan et al. (2017) and ours $^{50}$, a rough and partial check can be performed for rice by relying on our cross price elasticity of demand for Commercial Rice in relation to the price of PDS Rice as well as on the published Mixed Demand Elasticities of free market goods with respect to PDS quantity supply ${ }^{51}$.

By assuming that virtual prices of PDS Rice would rise to the level of observed market prices ${ }^{52}$ for Commercial Rice following the

\footnotetext{
50 The Only difference being that their commercial rice group includes ground rice whereas ours does not.

${ }^{51}$ Due to differences in the presentation of elasticities, we build the comparison using elasticities for the poorest quintile in rural areas published in Krishnan et al. (2017) with our elasticities and prices for the poorest decile.

52 Unit Values estimated directly form the IHSES 2012 survey data.
} 
elimination of PDS subsidies, our elasticities estimate an 8.33 percent reduction in consumption of Commercial Rice. In comparison, the published mixed demand elasticities estimate an 8.50 percent reduction in consumption of Commercial Rice following a 100 percent reduction in the supply of rice through the PDS.

These are clearly partial estimates and do not reflect the final expected demand for rice following subsidy elimination, especially since they do not account for the full dynamics of demand for rice in response to own prices and other cross price elasticities. Nonetheless, we consider the fact that both sets of elasticities estimate partial change in demand that is similar in direction and magnitude as a rough verification of our estimated elasticities.

\section{Nutrient Demand Elasticities}

The estimated food demand system is translated into nutrient expenditure and price elasticities as specified in equations (26) and (27) using the unconditional third stage matrix of elasticities.

\section{Table 8: Nutrient Expenditure Elasticities $\left(\rho_{k}\right)$ Nationally and by Decile}

Calories Protein Fat hydrates Iron Zinc Folate Vit. A $\quad \begin{array}{r}\text { Vit. } \\ \text { B12 }\end{array}$

\begin{tabular}{llllllllll} 
& & & & & & & & & \\
National & 0.507 & 0.524 & 0.762 & 0.399 & 0.480 & 0.514 & 0.668 & 0.753 & 0.896 \\
& & & & & & & & & \\
Decile 1 & 0.325 & 0.346 & 0.602 & 0.237 & 0.321 & 0.313 & 0.623 & 0.876 & 0.917 \\
Decile 2 & 0.382 & 0.419 & 0.660 & 0.283 & 0.388 & 0.391 & 0.642 & 0.821 & 0.894 \\
Decile 3 & 0.430 & 0.458 & 0.706 & 0.324 & 0.417 & 0.441 & 0.650 & 0.789 & 0.902 \\
Decile 4 & 0.442 & 0.473 & 0.722 & 0.329 & 0.438 & 0.456 & 0.657 & 0.772 & 0.892 \\
Decile 5 & 0.481 & 0.498 & 0.748 & 0.372 & 0.448 & 0.480 & 0.658 & 0.749 & 0.889 \\
Decile 6 & 0.509 & 0.519 & 0.769 & 0.399 & 0.474 & 0.503 & 0.665 & 0.736 & 0.880 \\
Decile 7 & 0.552 & 0.553 & 0.800 & 0.443 & 0.502 & 0.553 & 0.673 & 0.714 & 0.905 \\
Decile 8 & 0.577 & 0.570 & 0.818 & 0.468 & 0.525 & 0.569 & 0.679 & 0.688 & 0.886 \\
Decile 9 & 0.627 & 0.602 & 0.837 & 0.529 & 0.559 & 0.606 & 0.679 & 0.663 & 0.861 \\
Decile 10 & 0.684 & 0.642 & 0.857 & 0.602 & 0.595 & 0.660 & 0.676 & 0.613 & 0.858 \\
\hline Source: & & & &
\end{tabular}

Source: Own calculation using IHSES 2012 
Generally, nutrient expenditure elasticities are low, though increasing in total expenditure. The exceptions being Vitamins A and B12, which are decreasing in total expenditure - a reflection of the fact that demand elasticities for Vegetables and Meats, the main sources of Vitamins $\mathrm{A}$ and $\mathrm{B} 12$ respectively, are also decreasing in total expenditure.

\section{Table 9: National Nutrient Price Elasticities $\left(\rho_{k}\right)$ by food group} and subgroup

Cereals
PDS Rice
Commercial Rice
PDS Wheat Flour
Commercial Wheat Flour
Bread \& Buns
Other Baked Goods
Other Cereals \& Cereal Prod.
Vegetables \& Pulses
Tomatoes
Eggplant
Potato
Onion
Cucumber
Pulses
Other Vegetables \& Veg. Prod.
Fruits
Orange
Apple
Water melon
Banana
Other Fresh Fruit
Other Processed Fruit
Oils \& Fats
PDS Vegetable Oil
Commercial Vegetable Oil
Other Fats \& Oils
Fish, Meat \& Eggs
Mutton
Beef
Chicken
Other Meats and Offals
Fish \& Seafood
Eggs
Milk \& Dairy Products
Milk
Infant Formula
Yogurt
Cheese
Other Dairy
Sugars \& Syrups
PDS Sugar
Comm Sugar
Other Sugars \& Syrups
Miscellaneous Foods
Seeds and Nuts
Spices
Condiments
Beverages
Other Miscellaneous

Ond

\begin{tabular}{|c|c|c|c|c|c|c|c|c|}
\hline Calories & Protein & Fat & $\begin{array}{l}\text { Carbo- } \\
\text { hydrates }\end{array}$ & Iron & Zinc & Folate & Vit. A & Vit. B12 \\
\hline-0.337 & -0.375 & -0.060 & -0.440 & -0.408 & -0.417 & -0.208 & -0.020 & 0.016 \\
\hline-0.019 & -0.048 & -0.015 & -0.010 & -0.074 & -0.060 & -0.034 & -0.002 & 0.001 \\
\hline-0.199 & -0.175 & 0.017 & -0.301 & -0.140 & -0.183 & -0.012 & -0.005 & 0.007 \\
\hline 0.074 & -0.005 & 0.064 & 0.107 & -0.050 & -0.027 & 0.021 & -0.005 & 0.010 \\
\hline-0.005 & -0.011 & -0.001 & -0.004 & -0.019 & -0.005 & -0.007 & 0.000 & 0.000 \\
\hline-0.360 & -0.296 & -0.186 & -0.454 & -0.295 & -0.314 & -0.234 & -0.006 & 0.001 \\
\hline 0.104 & 0.100 & 0.029 & 0.136 & 0.095 & 0.111 & 0.036 & -0.001 & 0.000 \\
\hline 0.045 & 0.039 & 0.032 & 0.052 & 0.053 & 0.044 & 0.021 & -0.002 & 0.000 \\
\hline-0.151 & -0.177 & -0.105 & -0.160 & -0.213 & -0.186 & -0.377 & -0.479 & -0.048 \\
\hline-0.052 & -0.075 & -0.030 & -0.052 & -0.092 & -0.079 & -0.250 & -0.315 & -0.012 \\
\hline 0.001 & 0.005 & -0.006 & 0.002 & 0.009 & 0.005 & 0.030 & 0.035 & -0.003 \\
\hline-0.017 & -0.016 & -0.011 & -0.020 & -0.015 & -0.015 & -0.027 & -0.023 & -0.006 \\
\hline-0.001 & 0.004 & -0.004 & -0.001 & 0.009 & 0.005 & 0.027 & 0.052 & -0.003 \\
\hline 0.004 & 0.014 & -0.008 & 0.006 & 0.017 & 0.012 & 0.071 & 0.057 & -0.005 \\
\hline-0.029 & -0.060 & -0.014 & -0.025 & -0.073 & -0.057 & -0.228 & 0.009 & -0.005 \\
\hline-0.016 & -0.008 & -0.030 & -0.014 & -0.023 & -0.014 & 0.006 & -0.311 & -0.016 \\
\hline 0.013 & 0.025 & 0.031 & 0.004 & 0.021 & 0.025 & -0.016 & -0.080 & 0.029 \\
\hline-0.010 & -0.002 & 0.004 & -0.017 & -0.003 & -0.001 & -0.021 & -0.045 & 0.005 \\
\hline 0.014 & 0.008 & 0.008 & 0.018 & 0.011 & 0.009 & 0.022 & 0.050 & 0.005 \\
\hline 0.003 & 0.003 & 0.005 & 0.002 & 0.003 & 0.003 & 0.006 & -0.014 & 0.004 \\
\hline 0.020 & 0.010 & 0.008 & 0.026 & 0.013 & 0.009 & 0.028 & 0.081 & 0.004 \\
\hline-0.015 & -0.003 & 0.007 & -0.026 & -0.008 & -0.004 & -0.034 & -0.093 & 0.010 \\
\hline-0.013 & -0.004 & -0.001 & -0.018 & -0.008 & -0.004 & -0.018 & -0.059 & 0.001 \\
\hline-0.077 & 0.012 & -0.339 & 0.011 & 0.012 & 0.013 & 0.011 & 0.008 & 0.006 \\
\hline-0.049 & 0.004 & -0.206 & 0.003 & 0.004 & 0.005 & 0.006 & 0.005 & 0.004 \\
\hline 0.123 & 0.005 & 0.481 & 0.002 & 0.003 & 0.003 & 0.003 & 0.007 & 0.004 \\
\hline-0.143 & -0.001 & -0.568 & 0.000 & 0.000 & 0.000 & 0.001 & -0.003 & -0.001 \\
\hline 0.015 & -0.119 & -0.066 & 0.074 & -0.010 & -0.059 & -0.011 & -0.029 & -0.652 \\
\hline-0.004 & -0.011 & -0.022 & 0.004 & -0.001 & -0.026 & 0.005 & 0.003 & -0.098 \\
\hline-0.002 & -0.008 & -0.014 & 0.004 & -0.002 & -0.014 & 0.000 & 0.002 & -0.045 \\
\hline-0.002 & -0.068 & -0.014 & 0.016 & 0.000 & -0.014 & 0.005 & -0.012 & -0.032 \\
\hline-0.003 & -0.025 & -0.008 & 0.003 & -0.020 & -0.025 & 0.001 & -0.007 & -0.219 \\
\hline-0.001 & -0.010 & -0.003 & 0.002 & 0.004 & 0.000 & 0.002 & 0.003 & -0.018 \\
\hline 0.003 & -0.014 & -0.005 & 0.010 & -0.015 & -0.003 & -0.026 & -0.018 & -0.238 \\
\hline-0.017 & -0.021 & -0.082 & 0.009 & 0.001 & -0.013 & 0.010 & -0.091 & -0.140 \\
\hline-0.004 & -0.006 & -0.009 & -0.001 & 0.001 & -0.005 & -0.001 & -0.003 & -0.051 \\
\hline-0.001 & -0.001 & -0.004 & 0.000 & 0.000 & -0.002 & 0.000 & -0.001 & -0.011 \\
\hline-0.003 & -0.004 & -0.011 & 0.001 & -0.014 & -0.015 & 0.000 & -0.039 & -0.036 \\
\hline-0.008 & -0.014 & -0.030 & 0.002 & 0.004 & 0.003 & 0.007 & -0.033 & -0.011 \\
\hline-0.009 & -0.006 & -0.025 & -0.003 & -0.001 & -0.004 & 0.001 & -0.012 & -0.024 \\
\hline-0.074 & 0.008 & -0.020 & -0.118 & -0.023 & 0.007 & 0.008 & 0.008 & 0.004 \\
\hline-0.051 & 0.002 & -0.004 & -0.084 & -0.016 & 0.002 & 0.003 & 0.003 & 0.003 \\
\hline-0.104 & -0.001 & -0.006 & -0.174 & -0.036 & -0.001 & 0.000 & 0.001 & -0.001 \\
\hline 0.081 & 0.003 & -0.008 & 0.139 & 0.026 & 0.002 & 0.004 & 0.004 & 0.004 \\
\hline-0.010 & -0.002 & -0.045 & 0.003 & -0.007 & -0.004 & -0.057 & 0.015 & -0.005 \\
\hline-0.077 & -0.057 & -0.174 & -0.040 & -0.062 & -0.054 & -0.151 & -0.006 & -0.001 \\
\hline-0.053 & -0.041 & -0.113 & -0.028 & -0.046 & -0.039 & -0.149 & 0.001 & -0.002 \\
\hline 0.071 & 0.052 & 0.154 & 0.039 & 0.059 & 0.051 & 0.152 & 0.007 & 0.000 \\
\hline-0.012 & -0.006 & -0.033 & -0.004 & -0.014 & -0.014 & -0.036 & 0.007 & -0.002 \\
\hline 0.054 & 0.043 & 0.117 & 0.029 & 0.050 & 0.043 & 0.129 & 0.008 & 0.000 \\
\hline
\end{tabular}

Source: Own calculation using IHSES 2012. Elasticities represent the change in consumption of [nutrient] in relation to changes in the price of [food] 
Carbohydrates, the main source of kilocalories, is the least elastic of all considered nutrients at the national level and across total expenditure deciles except the wealthiest decile.

Expenditure elasticity of demand for Calories is lowest for the poorest deciles and increases with total expenditure, coinciding with a decreasing proportion of calories from cereals in favor of more superior goods such as Fish, Meat \& Eggs.

Nutrient demand is generally price inelastic (Table 9). The price elasticities, estimated through equation (26), represent the weighted average of both own and cross price effects and reflect the degree to which households are able to adapt to price shocks through substitution. The elasticities for Calories, Protein, Carbohydrates, Iron and Zinc are highest (in absolute terms) in relation to the price Cereals and Cereal Products. This is a result of the higher dependence on this food group for nutrients where PDS Wheat Flour alone contributes 29 percent of calories, 38 percent of proteins, 35 percent of carbohydrates, 45 percent of Iron and 44 percent of all Zinc consumed by Iraqi households on average. The high contribution of PDS Wheat Flour to micronutrients is a result of the fact that, by law, all wheat flour in Iraq is fortified.

Similarly, since Vegetables and Pulses contributes the highest proportions of consumed Folate and Vitamin A, these nutrients are most responsive to the prices of Vegetables and Pulses and of course the same applies to Vitamin B12 and the price of Eggs and Other Meats and Offal.

Whether the elasticity of demand for an individual nutrient is increasing or decreasing in prices relies on the own-price and cross price elasticities of the food group/subgroup in question as well as the contribution of the food to the overall consumption of the nutrient. Accordingly, the positive calorie elasticity with respect to the prices of Fruits or Fish, Meat and Eggs reflects the fact that the Cereals and 
Oils and Fats food groups are substitutes - both of which are rich in dietary energy.

Figure 2: Price Elasticity of Calories w.r.t. PDS items and their commercial equivalents by decile

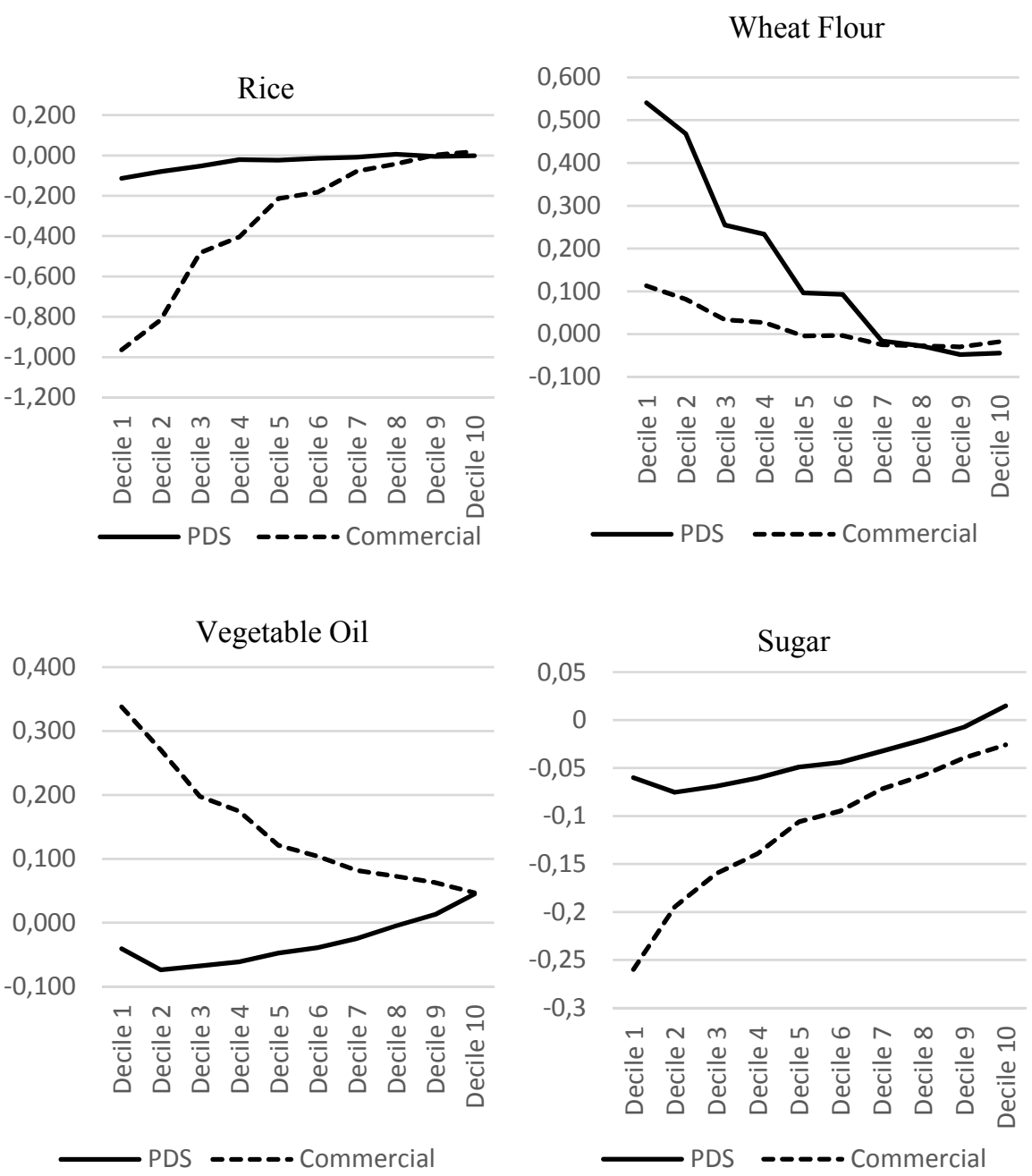

Focusing on calorie elasticities of PDS food items and their commercial equivalents (Figure 2) it is apparent that price elasticities of calories with regard to the price of PDS food items vary less across 
deciles than with regard to their commercial equivalents. The positive calorie elasticities in relation to the price of PDS Wheat Flour, particularly for the poorer deciles suggests that households are able to safeguard the calorie consumption in the face of increasing prices through substitution. This is also true for the other PDS food items despite the negative calorie elasticities in relation to their prices particularly given that the magnitude of elasticities are rather low. In addition, differences in calorie price elasticities for PDS food items compared to their commercial equivalents are greatest among the poorest deciles yet narrow significantly among the wealthiest deciles.

\subsection{Conclusion}

Despite the high reliance on food subsidies in the Arab States, very little is known about the structure of their demand for food and nutrients and Iraq is no exception. Much planning and analysis by Government and international development partners has been undertaken to support the reform of the Iraqi Public Distribution System (PDS), yet no attempt has been made to estimate food and nutrients demand elasticities for Iraq.

While the turbulent past of Iraq may have prevented the estimation of such demand elasticities, the increased availability of reliable household budget surveys alongside a desire of the Government of Iraq to undertake economic reforms suggests that an in depth understanding of the population preferences and consumption responses to income and price signals will be of great value to policy analysts.

The contribution of this paper is to bridge this critical gap by presenting a complete food demand system for Iraq encompassing 42 food items and aggregate commodity groups. The food demand 
system estimation proceeds assuming a three stage budgeting process whereby households first allocate expenditures between food and non-food groups, followed by allocations between 8 food groups in the second stage, which are further disaggregated into 42 subgroups in the third stage, with each group containing between 3 and 7 sub groups.

Subsidized PDS food commodities included in the demand system are valued at their virtual prices allowing estimation of an unconstrained Quadratic Almost Ideal Demand System (QUAIDS) yielding "free" demand elasticities. The virtual prices are estimated through the estimation of the Normalized Quadratic Mixed Demand model for PDS commodities and their free market equivalents.

All stages in the estimation of the demand system account for demographic variables and, for third stage fruits and vegetable models, seasonality as well. In addition, the second and third stage QUAIDS models are adapted to account for censoring of the data due to non-acquisition of specific food items during the survey reference period.

The estimated expenditure elasticities reveal that Iraqi consumers consider most commodities to be normal goods with positive expenditure elasticities, though less than unity. Some commodities, such as Commercial Vegetable Oil, Commercial Sugar, Mutton, Beef and Milk are considered superior goods with positive expenditure elasticities higher than unity. The elasticities also reveal that PDS Rice and Commercial Wheat Flour are considered inferior goods with the negative expenditure elasticities for these two subgroups indicate decreasing desirability as total expenditure increases. The estimated price elasticities indicate substantial price responsiveness of demand for subgroups. Price elastic subgroups include Commercial Rice, Wheat Flour and Sugar, Breads and Buns and Other Baked Goods, Other Fresh and Processed Fruits and all Miscellaneous Foods group. 
A further contribution of this paper is the identification of Giffen behavior in relation to PDS Rice, for which the estimated population mean expenditure elasticity is estimated at -0.272 and own price elasticity at 0.454 on average. The Giffen behavior described in this paper echoes similar results for Rice found by Jensen and Miller (2007) for Urban poor population in China. This implies that Giffen behavior in relation to subsidized staple goods may be more common than is currently acknowledged - a proposition that merits further examination as it bears significant implications for consumption subsidy policies.

We apply the matrix of expenditure, own and cross price elasticities to estimate nutrient expenditure and price elasticities for calories and 8 macro and micronutrients including Protein, Fat, Carbohydrates, Iron, Zinc, Folate, Vitamin A and Vitamin B12. Generally, nutrients are found to be expenditure and price inelastic. Overall, nutrient expenditure elasticities are increasing in total expenditure with the exception of Vitamins A and B12, which are decreasing in total expenditure. Some commodities, including PDS Wheat Flour which is the cheapest and largest contributor to total calorie consumption - are estimated to have positive nutrient price elasticities, suggesting that households are able to substantially mitigate price shocks through substitution. 


\subsection{Bibliography}

Abdulai, A. (2002). Household demand for food in Switzerland: A quadratic almost ideal demand system. Swiss Journal of Economic Statistics, 138, 1-18.

Abdulai, A., \& Aubert, D. (2004). Nonparametric and Parametric Analysis of Calorie Consumption in Tanzania. Food Policy, 29, 113-129.

Abou Zaki, S., Chaaban, J., Nasreddine, L., \& Chalak, A. (2014). The impact of food price increases on nutrient intake in Lebanon. Agricultural and Food Economics, 2(3).

Anand, R., Kumar, N., \& Tulin, V. (2016). Understanding India's Food Inflation: The Role of Demand and Supply Factors. IMF Working Paper, Asia and Pacific Department, WP/16/2.

Banks, J., Blundell, R., \& Lewbel, A. (1997). Quadratic Engel Curves and Consumer Demand. The Review of Economics and Statistics, 79(4), 527-539.

Bergtold, J., Akobundu, E., \& Peterson, E. (2004). The FAST Method: Estimating Unconditional Demand Elasticities for Processed Foods in the Presence of Fixed Effects. 29(2), 276295.

Bettendorf, L., \& Buyst, E. (1997). Rent Control and Virtual Prices: A Case Study for Interwar Belgium. The Journal of Economic History, 57(3), 654-673.

Bouis, H., \& Haddad, L. (1992). Are Estimates of Calorie-Income Elasticities Too High? A Racalibration of the Plausible Range. Journal of Development Economics, 39(2), 333-364.

Deaton, A., \& Muellbauer, J. (1980). An Almost Ideal Demand System. American Economic Review, 70(3), 312-326.

Ecker, O., \& Qaim, M. (2011). Analyzing Nutritional Impacts of Policies: An Empirical Study for Malawi. World Development, 39(3), $412-428$.

Edgerton, D. L. (1997). Weak separability and the estimation of elasticities in multistage demand systems. American Journal of Agricultural Economics, 79(1), 62-79.

El-Sherbini, A. (Ed.). (1979). Food security issues in the Arab near east: A report of the United Nations Economic Commission 
for West Asia. Beirut: Economic Commission for Western Asia.

Fashogbon, A., \& Oni, O. (2013). Heterogeneity in Rural Household Food Demand and Its Determinants in Ondo State, Nigeria: An Application of Quadratic Almost Ideal Demand System. Journal of Agricultural Science, 5(2), 169.

Fleissig, A., \& Whitney, G. (2014). Estimating Demand Elasticities Under Rationing. Applied Economics, 46(4), 432-440.

Gao, G. (2011). World Food Demand. Amer. J. Agr. Econ., 94(1), $25-51$.

Green, R., Cornelsen, L., Dangour, A., Turner, R., Shankar, B., Mazzocchi, M., \& Smith, R. (2013). The effect of rising food prices on food consumption: systematic review with metaregression. BMJ.

Hanemann, M., \& Morey, E. (1992). Separability, Partial Demand and Consumer's Surplus Measures. Journal of Environmental Economics and Management, 22, 241-259.

Huang, K. (1996). Nutrient Elasticities in a Complete Food Demand System. American Journal of Agricultural Economics, 78(1), 21-29.

Huffman, S., \& Johnson, S. (2004). Impacts of Economic Reform in Poland: Incidence and Welfare Changes Within a Consistent Framework. The Review of Economics and Statistics, 86(2), 626-636.

Jensen, R., \& Miller, N. (2008). Giffen Behavior and Subsistence Consumption. American Economic Review, 98(4), 1553-77.

Krishnan, N., Olivieri, S., \& Ramadan, R. (2017). Estimating the Welfare Costs of Reforming the Iraq Public Distribution System: A Mixed Demand Approach. Policy Research Working Paper 8106. Washington, DC: World Bank Group.

Kumar, P., Kumar, A., Parappurathu, S., \& Raju, S. (2011).

Estimation of Demand Elasticity for Food Commodities in India. Agricultural Economics Research Review, 24(1), 1-14. Lakkakula, P., Schmitz, A., \& Ripplinger, D. (2016). U.S. Sweetener Demand Analysis: A QUAIDS Model Application. Journal of Agricultural and Resource Economics, 41(3), 533-548.

Lambert, R., Larue, R., Yelou, C., \& Criner, G. (2006). Fish and Meat Demand in Canada. Regional Differences and Weak Separability. Agribusiness, 22(2), 175 - 199. 
Mittal, S. (2010). Application of the QUAIDS model to the food sector in India. Journal of Quantitative Economics, 8(1), 4254.

Moro, D., \& Sckokai, P. (2000). Heterogeneous Preferences in Household Food Consumption in Italy. European Review of Agricultural Economics, 27(3), 305-323.

Moschini, G., \& Rizzi, P. (2007). Deriving a Flexible Mixed Demand System: The Normalized Quadratic Model. American Journal of Agricultural Economics, 89(4), 1034-1045.

Moschini, G., \& Vissa, A. (1993). Flexible Specification of Mixed Demand Systems. American Journal of Agricultural Economics, 75(1), 1-9.

Moschini, G., Moro, D., \& Green, R. (1994). Maintaining and Testing Separability in Demand Systems. American Journal of Agricultural Economics, 76(1), 61-73.

Muhammad, A., Seale, J. L., Meade, B., \& Regmi, A. (2011). International Evidence on Food Consumption Patterns: An Update Using 2005 International Comparison Program Data. USDA ERS Technica Bulletin No. 1929. Washington, DC: USDA.

Neary, J., \& Roberts, K. (1980). The Theory of Household Behaviour Under Rationing. European Economic Review, 13, 25-42.

Pitt, M. (1983). Food preferences and nutrition in rural Bangladesh. Review of Economics and Statistics, 65(1), 105-114.

Poi, B. (2012). Easy demand-system estimation with quaids. Stata Journal, 22(3), 443-446.

Ramadan, R., \& Thomas, A. (2011). Evaluation the impact of reforming the food subsidy program in Egypt: a mixed demand approach. Food Policy, 36(5), 638-646.

Ray, R. (1983). Measuring the Costs of Children: An Alternative Approach. Journal of Public Economics, 22(1), 89-102.

Read, C. (2013). Giffen behaviour in Irish famine markets: an empirical study,. University of Cambridge Department of Economic and Social History Working Paper No.15.

Regmi, A., \& Seale, J. (2010). Cross-Price Elasticities of Demand Across 114 Countries. USDA Economic Research Service Technical Bulletin Number 1925. 
Sahn, D. (1988). The effect of price and income changes on foodenergy intake in Sri Lanka. Economic Development and Cultural Change, 36(2), 315-340.

Sdralevich, C., Sab, R., Zouhar, Y., \& Albertin, G. (2014). Subsidy Reform in the Middle East and North Africa: Recent Progress and Challenges Ahead. International Monetary Fund, Middle East and Central Asia Department. Washington, DC: International Monetary Fund.

Shimeles, A. (2010). Welfare Analysis Using Data from the International Comparison Program for Africa. Working Paper No. 122. African Development Bank Group.

Shonkwiler, J., \& Yen, S. (1999). Two-Step Estimation of a Censored System of Equations. American Journal of Agricultural Economics, 81(4), 972-982.

Sibrian, R., Ramasawmy, S., \& Mernies, J. (2007). Measuring hunger at sub-national levels from household surveys using the FAO approach: Manual. Rome: FAO Statistics Division Working Paper Series No. ESS/ESSA/005e.

Starzec, C., \& Gardes, F. (2014). Measuring Inflation Under

Rationing: A Virtual Price Approach. Documents de travail du Centre d'Economie de la Sorbonne.

Ulubasoglu, M., Mallick, D., Wadud, M., Hone, P., \& Haszler, H. (2015). Food demand elasticities for Australia. The Australian Journal of Agricultural and Resource Economics, 60(2), 177195.

UN, \& GOI. (2011). Iraq Knowledge Network Survey Report. United Nations Information and Analysis Unit, Iraqi Central

Statistical Organization and the Kurdistan Region Statistical Office.

Wang, Z., \& Kinsey, J. (1994). Consumption and Saving Behavior Under Strict and Partial Rationing. China Economic Review, 4(1), 83-100.

WFP \& GOI. (2012). Food Security, Living Conditions and Social Transfers in Iraq. United Nations Worls Food Programme and the Government of Iraq.

WFP. (2008). Comprehensive Food Security and Vulnerability

Analysis in Iraq. Baghdad: World Food Programme. 
Widarjono, A. (2012). An Analysis of Protein and Calorie

Consumption in Central Java. Economic Journal of Emerging Markets, 4(2), 115-126.

Widarjono, A. (2012). An Analysis of Protein and Calorie

Consumption in Central Java. Economic Journal of Emerging Markets, 4(2), 115-126.

Winkler, R. (2015). Feast or Famine: The Welfare Impact of Food Price Controls in Nazi Germany. University of Oxford Discussion Papers in Economic and Social History, Number 136.

World Bank \& GOI. (2011). Confronting Poverty in Iraq. Washington, DC: World Bank and Iraq Poverty Reduction Strategy High Committee.

World Bank. (2014). Iraq - The unfulfilled promise of oil and growth : Poverty, Inclusion and Welfare in Iraq 2007-2012. Washington, DC: World Bank Group.

Yen, S., Kan, K., \& Su, S. (2002). Household demand for fats and oils: Two-step estimation of a censored demand system. Applied Economics, 34(14), 1799-1806.

Yu, X., \& Shimokawa, S. (2016). Nutritional impacts of rising food prices in African countries: a review. Food Security, 8, 985997.

Zheng, Z., \& Henneberry, S. (2012). Estimating the impacts of rising food prices on nutrient intake in urban China. China Economic Review, 23(4), 1090-1103. 


\subsection{Appendices}

\section{Appendix 4A: Stage one Working-Lesser Model Parameters}

Dependent Variable $=$ Food Budget Share

Coefficient (s.e.)

$\operatorname{Ln}($ price $)$

$0.108^{* * *}$

$(0.0025)$

$\operatorname{Ln}($ Expenditure $)$

$-0.078 * * *$

$(0.0015)$

Household Size

$-0.002 * * *$

$(0.0003)$

Rural

$0.073 * * *$

$(0.0018)$

constant

$0.404 * * *$

(0.0036)

R-square

0.206

$\mathrm{N}$

25142 


\section{Appendix 4B: Stages two and three QUAIDS Model Parameters}

Table 4B.1: Stages two and three Samples and Equation R-Squared

\begin{tabular}{|c|c|c|c|c|c|c|c|c|c|}
\hline \multicolumn{10}{|c|}{ All Food } \\
\hline & Groups & Cereal & Veg. & Fruit & Meat & Dairy & Misc. & Oil & Sugar \\
\hline w1 & 0.7459 & 0.5944 & 0.8230 & 0.3804 & 0.2958 & 0.2069 & 0.1823 & 0.9851 & 0.9584 \\
\hline w2 & 0.8971 & 0.4627 & 0.5199 & 0.3668 & 0.3103 & 0.2405 & 0.3151 & 0.7689 & 0.2180 \\
\hline w3 & 0.6476 & 0.7913 & 0.6306 & 0.3013 & 0.5150 & 0.5521 & 0.0990 & 0.3004 & 0.8294 \\
\hline w4 & 0.5330 & 0.0842 & 0.4247 & 0.2702 & 0.2481 & 0.6239 & 0.4456 & $\ldots$ & $\ldots$ \\
\hline w5 & 0.8686 & 0.6017 & 0.5635 & 0.5670 & 0.2960 & 0.3250 & 0.3186 & $\ldots$ & $\ldots$ \\
\hline w6 & 0.6698 & 0.2344 & 0.4469 & 0.1089 & 0.6160 & $\ldots$ & $\ldots$ & $\ldots$ & $\ldots$ \\
\hline w7 & 0.5050 & 0.2949 & 0.8044 & $\ldots$ & $\ldots$ & $\ldots$ & $\ldots$ & $\ldots$ & $\ldots$ \\
\hline w8 & 0.5043 & $\cdots$ & & $\cdots$ & $\cdots$ & $\cdots$ & $\cdots$ & $\ldots$ & $\cdots$ \\
\hline$N$ & 25141 & 23303 & 23300 & 20727 & 22814 & 21382 & 19174 & 23224 & 21768 \\
\hline
\end{tabular}

Table 4B.2: Stages two and three Parameter Estimates

\begin{tabular}{|c|c|c|c|c|c|c|c|c|c|}
\hline & All & Cereal & Veg. & Fruit & Meats & Dairy & Misc. & Oil & Sugar \\
\hline$\alpha_{1}$ & $0.169 * *$ & $0.262^{* *}$ & $0.297 * *$ & $0.062^{* *}$ & $0.429 * *$ & $0.084 * *$ & $0.117^{*}$ & $0.552^{* *}$ & $0.613^{* *}$ \\
\hline$\alpha_{2}$ & $0.315^{* *}$ & $-0.374 * *$ & $0.079 * *$ & $0.083^{* *}$ & $0.775^{* *}$ & $0.175^{* *}$ & $0.201^{* *}$ & $0.213^{* *}$ & $-0.222^{* *}$ \\
\hline$\alpha_{3}$ & $0.087^{* *}$ & $0.454 * *$ & $0.128 * *$ & $-0.231^{* *}$ & $-1.14 * *$ & $0.663^{* *}$ & $-1.02 * *$ & $0.058 * *$ & $0.290 * *$ \\
\hline$\alpha_{4}$ & $0.045^{* *}$ & $-0.21 * *$ & $0.049 * *$ & 0.000 & $0.613^{* *}$ & $0.116^{* *}$ & $0.196^{* *}$ & $\ldots$ & $\ldots$ \\
\hline$\alpha_{5}$ & $0.208^{* *}$ & $0.131 * *$ & $0.120 * *$ & $0.148^{* *}$ & $0.649 * *$ & -0.013 & $-0.111^{* *}$ & $\cdots$ & $\cdots$ \\
\hline$\alpha_{6}$ & $0.092 * *$ & $-0.163^{* *}$ & $0.052 * *$ & $-0.078 * *$ & $0.487^{* *}$ & $\ldots$ & $\ldots$ & $\ldots$ & $\ldots$ \\
\hline$\alpha_{7}$ & $0.036 * *$ & 0.013 & $0.229 * *$ & $\ldots$ & $\ldots$ & $\ldots$ & $\ldots$ & $\ldots$ & $\ldots$ \\
\hline$\alpha_{8}$ & $0.035^{* *}$ & $\ldots$ & $\ldots$ & $\ldots$ & $\ldots$ & $\ldots$ & $\ldots$ & $\ldots$ & $\ldots$ \\
\hline$\beta_{1}$ & $-0.009 *$ & $-0.077 * *$ & $-0.038 * *$ & $-0.044 * *$ & $0.061 * *$ & $0.162 * *$ & $-0.053^{* *}$ & $-0.146 * *$ & $-0.211 * *$ \\
\hline
\end{tabular}




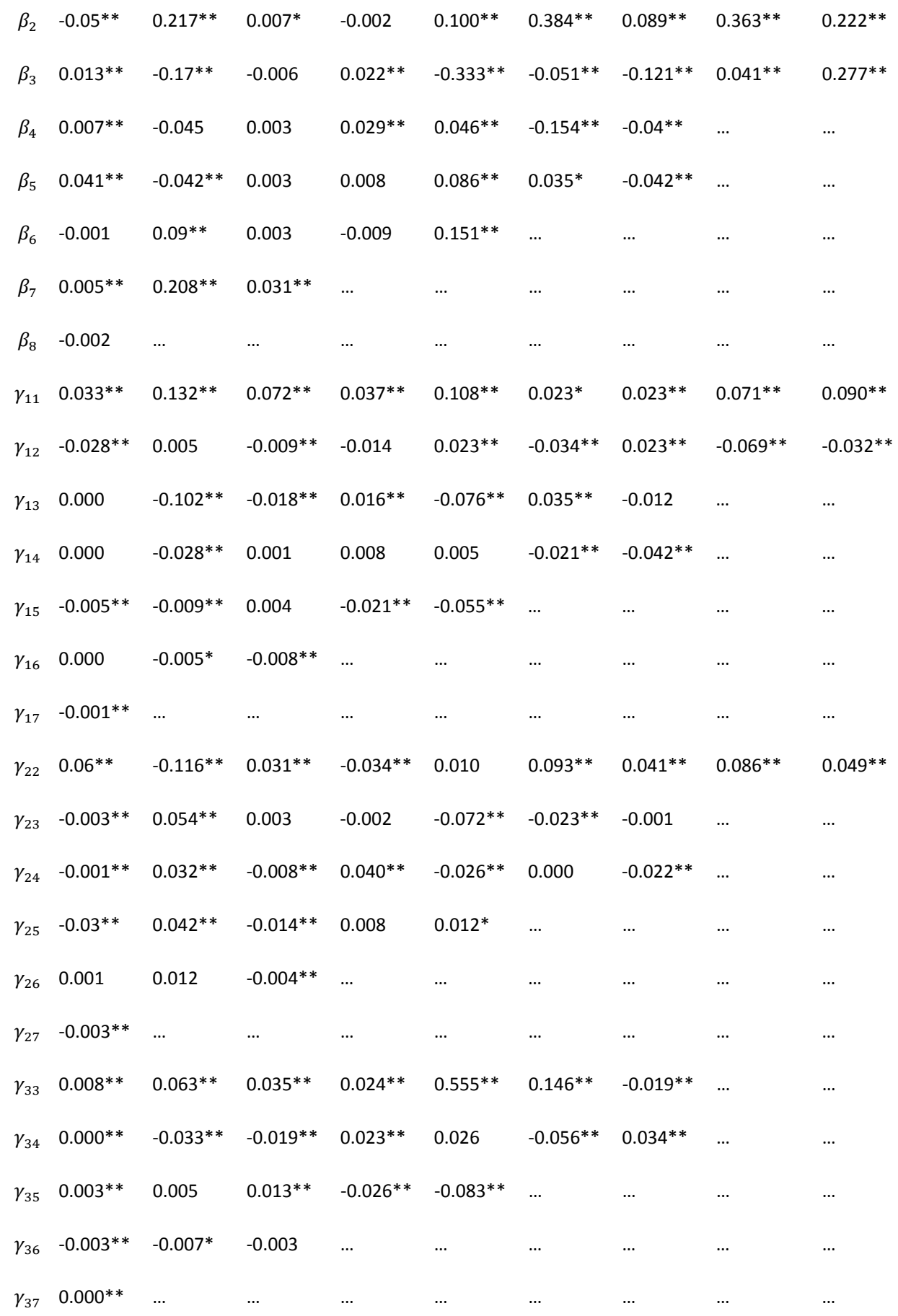




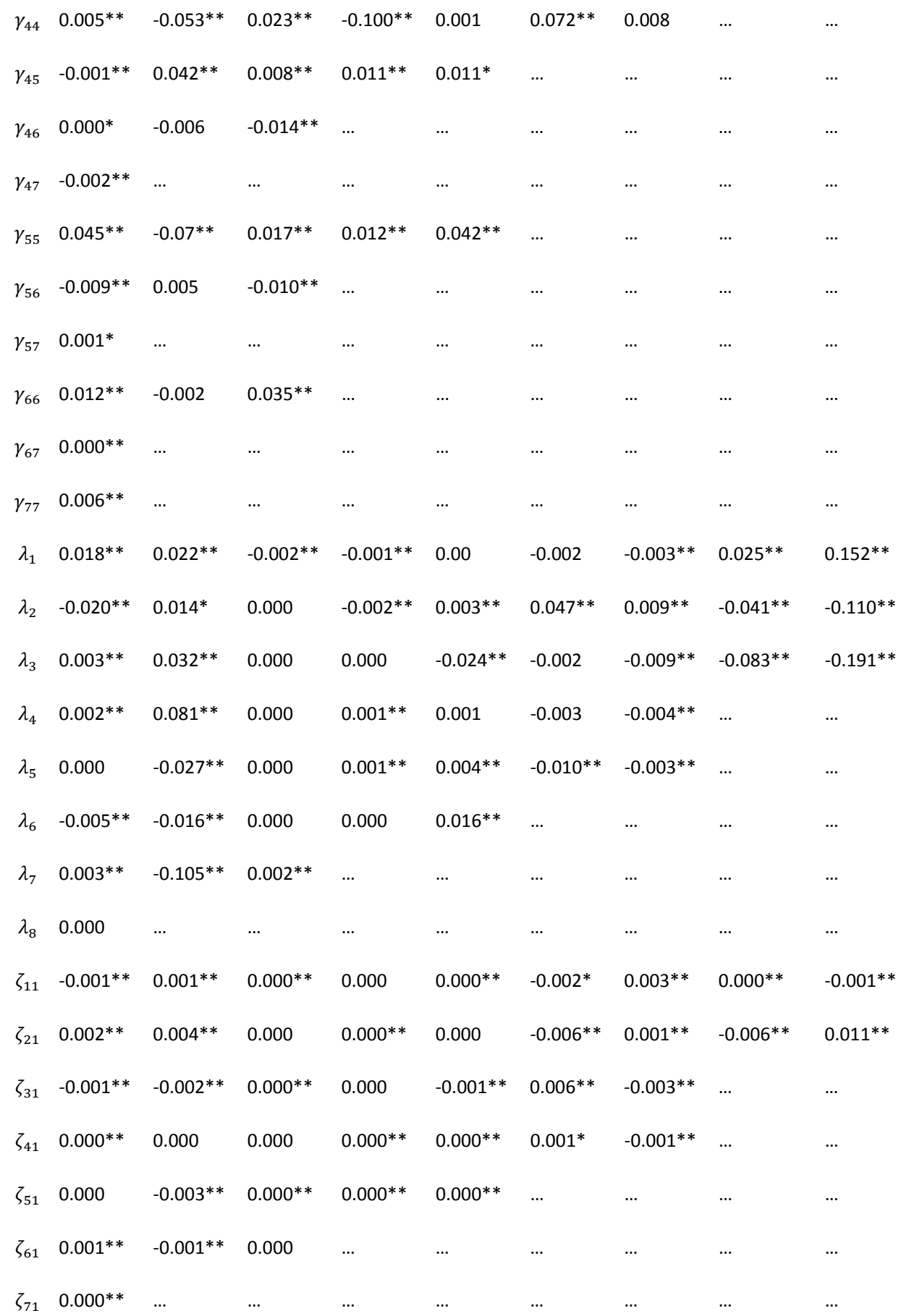




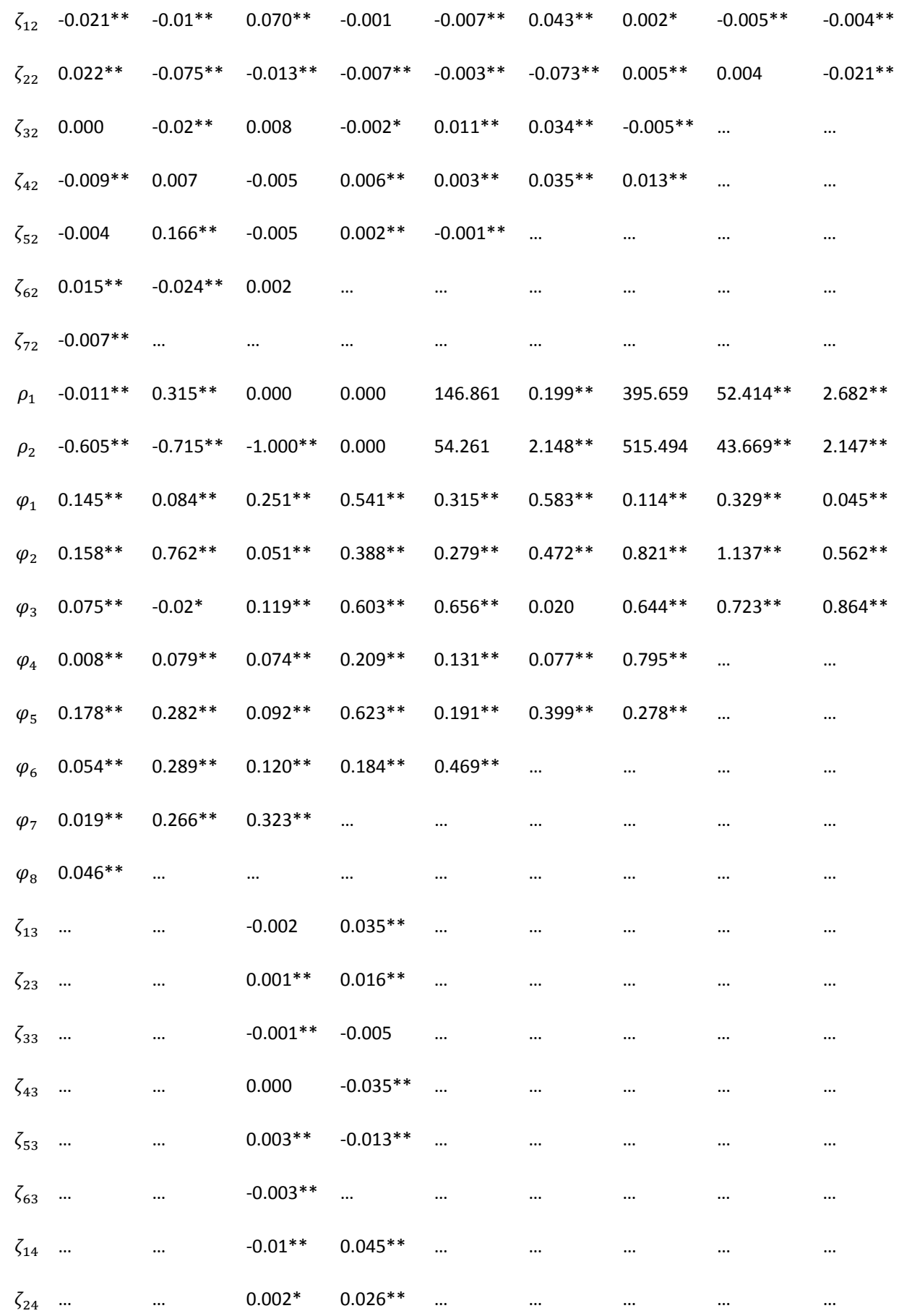




\begin{tabular}{cccccccccc}
$\zeta_{34}$ & $\ldots$ & $\ldots$ & $-0.002^{*}$ & -0.017 & $\ldots$ & $\ldots$ & $\ldots$ & $\ldots$ & $\ldots$ \\
$\zeta_{44}$ & $\ldots$ & $\ldots$ & 0.001 & $-0.045^{* *}$ & $\ldots$ & $\ldots$ & $\ldots$ & $\ldots$ & $\ldots$ \\
$\zeta_{54}$ & $\ldots$ & $\ldots$ & $0.004^{* *}$ & $-0.016^{* *}$ & $\ldots$ & $\ldots$ & $\ldots$ & $\ldots$ & $\ldots$ \\
$\zeta_{64}$ & $\ldots$ & $\ldots$ & -0.002 & $\ldots$ & $\ldots$ & $\ldots$ & $\ldots$ & $\ldots$ & $\ldots$ \\
$\zeta_{15}$ & $\ldots$ & $\ldots$ & $-0.006^{* *}$ & $0.045^{* *}$ & $\ldots$ & $\ldots$ & $\ldots$ & $\ldots$ & $\ldots$ \\
$\zeta_{25}$ & $\ldots$ & $\ldots$ & $0.001^{*}$ & $0.025^{* *}$ & $\ldots$ & $\ldots$ & $\ldots$ & $\ldots$ & $\ldots$ \\
$\zeta_{35}$ & $\ldots$ & $\ldots$ & -0.001 & $-0.019^{*}$ & $\ldots$ & $\ldots$ & $\ldots$ & $\ldots$ & $\ldots$ \\
$\zeta_{45}$ & $\ldots$ & $\ldots$ & $0.001^{* *}$ & $-0.043^{* *}$ & $\ldots$ & $\ldots$ & $\ldots$ & $\ldots$ & $\ldots$ \\
$\zeta_{55}$ & $\ldots$ & $\ldots$ & 0.001 & $-0.016^{* *}$ & $\ldots$ & $\ldots$ & $\ldots$ & $\ldots$ & $\ldots$ \\
$\zeta_{65}$ & $\ldots$ & $\ldots$ & $-0.001^{*}$ & $\ldots$ & $\ldots$ & $\ldots$ & $\ldots$ & $\ldots$ & $\ldots$ \\
$\rho_{3}$ & $\ldots$ & $\ldots$ & 0.000 & $-0.999^{* *}$ & $\ldots$ & $\ldots$ & $\ldots$ & $\ldots$ & $\ldots$ \\
$\rho_{4}$ & $\ldots$ & $\ldots$ & 0.000 & $-1.000^{* *}$ & $\ldots$ & $\ldots$ & $\ldots$ & $\ldots$ & $\ldots$ \\
$\rho_{5}$ & $\ldots$ & $\ldots$ & 0.000 & $-1.000^{* *}$ & $\ldots$ & $\ldots$ & $\ldots$ & $\ldots$ & \\
\hline
\end{tabular}




\section{Appendix 4C: Normalized Quadratic Demand Parameters}

Table 4C.1: Samples and Equation R-Squared

\begin{tabular}{lcc} 
& Number of Cases & Uncentered R-squared \\
\cline { 2 - 3 } w1 & 23365 & 0.5588 \\
w2 & 23365 & 0.4845 \\
w3 & 23365 & 0.2379 \\
w4 & 23365 & 0.4768 \\
w5 & 23365 & 0.4005 \\
w6 & 23365 & 0.0686 \\
w7 & 23365 & 0.2576 \\
w8 & 23365 & 0.0729 \\
\hline
\end{tabular}

Table 4C.2: Parameter Estimates

\begin{tabular}{|c|c|c|c|c|c|c|c|}
\hline \multicolumn{2}{|c|}{ Parameter } & \multirow{2}{*}{$\begin{array}{l}\text { Coefficient } \\
-1.8 \mathrm{E}-07\end{array}$} & \multirow{2}{*}{$\begin{array}{l}\text { Robust Std. Err. } \\
2.4 \mathrm{E}-06\end{array}$} & \multirow{2}{*}{$\frac{z}{-0.07}$} & \multirow{2}{*}{$\frac{P>z}{0.941}$} & \multicolumn{2}{|c|}{ [95\% Conf. Interval] } \\
\hline$\beta_{i j}$ & b55 & & & & & $-4.8 \mathrm{E}-06$ & $4.5 \mathrm{E}-06$ \\
\hline & b56 & $-2.7 \mathrm{E}-06$ & $3.7 \mathrm{E}-06$ & -0.75 & 0.455 & $-9.9 \mathrm{E}-06$ & $4.5 \mathrm{E}-06$ \\
\hline & b57 & $2.0 \mathrm{E}-06$ & $2.9 \mathrm{E}-06$ & 0.70 & 0.487 & $-3.6 \mathrm{E}-06$ & 7.6E-06 \\
\hline & b66 & $1.2 \mathrm{E}-05$ & $6.4 \mathrm{E}-06$ & 1.92 & 0.055 & $-2.6 \mathrm{E}-07$ & $2.5 \mathrm{E}-05$ \\
\hline & $\mathrm{b} 67$ & $-5.6 \mathrm{E}-06$ & $1.0 \mathrm{E}-05$ & -0.55 & 0.582 & $-2.5 \mathrm{E}-05$ & $1.4 \mathrm{E}-05$ \\
\hline & b77 & $1.0 \mathrm{E}-06$ & $2.1 \mathrm{E}-06$ & 0.50 & 0.617 & $-3.0 \mathrm{E}-06$ & $5.1 \mathrm{E}-06$ \\
\hline \multirow[t]{3}{*}{$\delta_{i}$} & $\mathrm{~d} 5$ & $-2.6 \mathrm{E}-02$ & $2.1 \mathrm{E}-03$ & -12.50 & 0.000 & $-3.0 \mathrm{E}-02$ & $-2.2 \mathrm{E}-02$ \\
\hline & d6 & $1.2 \mathrm{E}-01$ & $6.1 \mathrm{E}-03$ & 20.11 & 0.000 & $1.1 \mathrm{E}-01$ & $1.3 \mathrm{E}-01$ \\
\hline & d7 & $-8.2 \mathrm{E}-02$ & $3.3 \mathrm{E}-03$ & -24.66 & 0.000 & $-8.8 \mathrm{E}-02$ & $-7.5 \mathrm{E}-02$ \\
\hline \multirow[t]{3}{*}{$\beta_{i}$} & b5 & $2.1 \mathrm{E}-02$ & $1.6 \mathrm{E}-03$ & 13.03 & 0.000 & $1.8 \mathrm{E}-02$ & $2.4 \mathrm{E}-02$ \\
\hline & b6 & $-1.3 \mathrm{E}-02$ & $2.5 \mathrm{E}-03$ & -4.98 & 0.000 & $-1.8 \mathrm{E}-02$ & $-7.6 \mathrm{E}-03$ \\
\hline & b7 & $1.8 \mathrm{E}-02$ & $2.1 \mathrm{E}-03$ & 8.50 & 0.000 & $1.4 \mathrm{E}-02$ & $2.2 \mathrm{E}-02$ \\
\hline \multirow[t]{6}{*}{$\gamma_{k s}$} & g11 & $4.3 \mathrm{E}-04$ & $4.9 \mathrm{E}-04$ & 0.88 & 0.379 & $-5.3 \mathrm{E}-04$ & $1.4 \mathrm{E}-03$ \\
\hline & $\mathrm{g} 12$ & $2.6 \mathrm{E}-03$ & $6.7 \mathrm{E}-04$ & 3.92 & 0.000 & $1.3 \mathrm{E}-03$ & $4.0 \mathrm{E}-03$ \\
\hline & g13 & $1.0 \mathrm{E}-03$ & 4.1E-04 & 2.50 & 0.012 & $2.2 \mathrm{E}-04$ & $1.8 \mathrm{E}-03$ \\
\hline & g14 & $2.4 \mathrm{E}-03$ & 4.6E-04 & 5.27 & 0.000 & $1.5 \mathrm{E}-03$ & $3.3 \mathrm{E}-03$ \\
\hline & g22 & $1.0 \mathrm{E}-03$ & $1.1 \mathrm{E}-03$ & 0.92 & 0.357 & $-1.2 \mathrm{E}-03$ & $3.2 \mathrm{E}-03$ \\
\hline & g23 & $4.3 \mathrm{E}-03$ & $7.8 \mathrm{E}-04$ & 5.59 & 0.000 & $2.8 \mathrm{E}-03$ & $5.9 \mathrm{E}-03$ \\
\hline
\end{tabular}




\begin{tabular}{|c|c|c|c|c|c|c|c|}
\hline & g24 & $1.7 \mathrm{E}-03$ & $5.6 \mathrm{E}-04$ & 3.09 & 0.002 & $6.3 \mathrm{E}-04$ & $2.8 \mathrm{E}-03$ \\
\hline & g33 & $-2.6 \mathrm{E}-03$ & $1.1 \mathrm{E}-03$ & -2.41 & 0.016 & $-4.6 \mathrm{E}-03$ & $-4.8 \mathrm{E}-04$ \\
\hline & g34 & $2.3 \mathrm{E}-03$ & $5.2 \mathrm{E}-04$ & 4.41 & 0.000 & $1.3 \mathrm{E}-03$ & $3.3 \mathrm{E}-03$ \\
\hline & g44 & $1.4 \mathrm{E}-05$ & $3.5 \mathrm{E}-05$ & 0.40 & 0.690 & $-5.5 \mathrm{E}-05$ & $8.3 \mathrm{E}-05$ \\
\hline \multirow[t]{4}{*}{$\mu_{k}$} & $\mathrm{~m} 1$ & $-4.9 \mathrm{E}-02$ & $1.3 \mathrm{E}-03$ & -38.83 & 0.000 & $-5.2 \mathrm{E}-02$ & $-4.7 \mathrm{E}-02$ \\
\hline & $\mathrm{m} 2$ & $-5.0 \mathrm{E}-02$ & $1.3 \mathrm{E}-03$ & -36.76 & 0.000 & $-5.2 \mathrm{E}-02$ & $-4.7 \mathrm{E}-02$ \\
\hline & m3 & $-1.5 \mathrm{E}-02$ & $1.2 \mathrm{E}-03$ & -12.28 & 0.000 & $-1.7 \mathrm{E}-02$ & $-1.2 \mathrm{E}-02$ \\
\hline & $\mathrm{m} 4$ & $-4.0 \mathrm{E}-02$ & $1.4 \mathrm{E}-03$ & -28.54 & 0.000 & $-4.3 \mathrm{E}-02$ & $-3.7 \mathrm{E}-02$ \\
\hline \multirow[t]{4}{*}{$\gamma_{k}$} & g1 & $-2.0 \mathrm{E}-02$ & $2.3 \mathrm{E}-03$ & -8.42 & 0.000 & $-2.4 \mathrm{E}-02$ & $-1.5 \mathrm{E}-02$ \\
\hline & g2 & $-5.0 \mathrm{E}-02$ & $2.9 \mathrm{E}-03$ & -17.35 & 0.000 & $-5.6 \mathrm{E}-02$ & $-4.4 \mathrm{E}-02$ \\
\hline & g3 & $-8.8 \mathrm{E}-04$ & $1.7 \mathrm{E}-03$ & -0.51 & 0.609 & $-4.2 \mathrm{E}-03$ & $2.5 \mathrm{E}-03$ \\
\hline & g4 & $-4.6 \mathrm{E}-03$ & $2.0 \mathrm{E}-03$ & -2.28 & 0.023 & $-8.5 \mathrm{E}-03$ & $-6.5 \mathrm{E}-04$ \\
\hline \multirow{12}{*}{$\lambda_{j k}$} & 151 & $8.5 \mathrm{E}-03$ & $1.0 \mathrm{E}-03$ & 8.57 & 0.000 & $6.6 \mathrm{E}-03$ & $1.0 \mathrm{E}-02$ \\
\hline & 161 & 2.1E-03 & $6.0 \mathrm{E}-04$ & 3.43 & 0.001 & $8.8 \mathrm{E}-04$ & $3.2 \mathrm{E}-03$ \\
\hline & 171 & $2.6 \mathrm{E}-03$ & $4.5 \mathrm{E}-04$ & 5.73 & 0.000 & $1.7 \mathrm{E}-03$ & $3.4 \mathrm{E}-03$ \\
\hline & 152 & 2.3E-02 & $1.1 \mathrm{E}-03$ & 21.42 & 0.000 & $2.1 \mathrm{E}-02$ & $2.5 \mathrm{E}-02$ \\
\hline & 162 & 4.4E-03 & 4.4E-04 & 10.09 & 0.000 & $3.5 \mathrm{E}-03$ & $5.3 \mathrm{E}-03$ \\
\hline & 172 & 9.7E-03 & $5.1 \mathrm{E}-04$ & 18.82 & 0.000 & 8.7E-03 & $1.1 \mathrm{E}-02$ \\
\hline & 153 & $-1.1 \mathrm{E}-03$ & $6.6 \mathrm{E}-04$ & -1.73 & 0.084 & $-2.4 \mathrm{E}-03$ & $1.5 \mathrm{E}-04$ \\
\hline & 163 & 4.3E-04 & 2.6E-04 & 1.64 & 0.101 & $-8.4 \mathrm{E}-05$ & $9.5 \mathrm{E}-04$ \\
\hline & 173 & $-1.6 \mathrm{E}-03$ & 3.4E-04 & -4.77 & 0.000 & $-2.3 \mathrm{E}-03$ & $-9.7 \mathrm{E}-04$ \\
\hline & 154 & $-1.3 \mathrm{E}-04$ & $8.5 \mathrm{E}-04$ & -0.16 & 0.875 & $-1.8 \mathrm{E}-03$ & $1.5 \mathrm{E}-03$ \\
\hline & 164 & $4.5 \mathrm{E}-04$ & 2.4E-04 & 1.86 & 0.062 & $-2.3 \mathrm{E}-05$ & $9.1 \mathrm{E}-04$ \\
\hline & 174 & $-8.9 \mathrm{E}-04$ & $4.0 \mathrm{E}-04$ & -2.22 & 0.026 & $-1.7 \mathrm{E}-03$ & $-1.1 \mathrm{E}-04$ \\
\hline \multirow[t]{4}{*}{$\varphi_{k}$} & fl & $9.7 \mathrm{E}-02$ & $3.0 \mathrm{E}-03$ & 31.87 & 0.000 & $9.1 \mathrm{E}-02$ & $1.0 \mathrm{E}-01$ \\
\hline & $f 2$ & 3.8E-01 & $6.7 \mathrm{E}-03$ & 57.16 & 0.000 & 3.7E-01 & 3.9E-01 \\
\hline & f3 & 3.3E-02 & $2.2 \mathrm{E}-03$ & 14.49 & 0.000 & $2.8 \mathrm{E}-02$ & 3.7E-02 \\
\hline & f4 & $1.7 \mathrm{E}-01$ & $5.2 \mathrm{E}-03$ & 32.32 & 0.000 & $1.6 \mathrm{E}-01$ & $1.8 \mathrm{E}-01$ \\
\hline \multirow{4}{*}{$\varphi_{i}$} & f5 & $1.2 \mathrm{E}+00$ & $1.1 \mathrm{E}-02$ & 110.78 & 0.000 & $1.2 \mathrm{E}+00$ & $1.2 \mathrm{E}+00$ \\
\hline & f6 & $1.4 \mathrm{E}-01$ & $1.1 \mathrm{E}-02$ & 13.30 & 0.000 & $1.2 \mathrm{E}-01$ & $1.6 \mathrm{E}-01$ \\
\hline & f7 & $5.9 \mathrm{E}-01$ & $1.0 \mathrm{E}-02$ & 56.90 & 0.000 & 5.7E-01 & $6.2 \mathrm{E}-01$ \\
\hline & f8 & $-4.1 \mathrm{E}-01$ & $1.0 \mathrm{E}-02$ & -40.78 & 0.000 & $-4.3 \mathrm{E}-01$ & $-3.9 \mathrm{E}-01$ \\
\hline
\end{tabular}




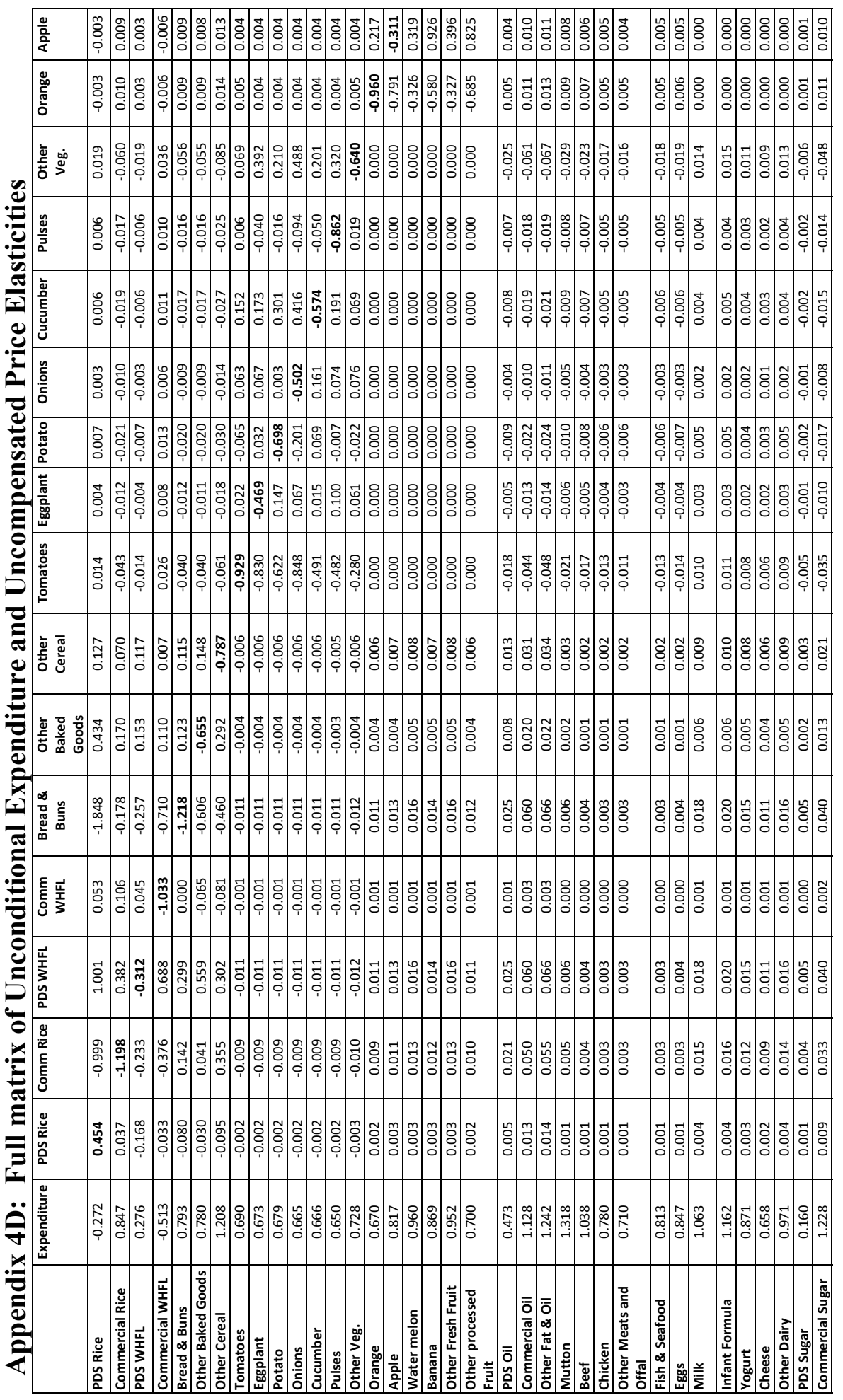




\begin{tabular}{|c|c|c|c|c|c|c|c|c|c|c|c|c|c|c|c|c|c|c|c|c|c|c|c|}
\hline  &  & לे. & 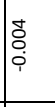 & : & & $\begin{array}{lll}0 & 0 \\
0 & 0 & 0 \\
0 & 0 \\
0\end{array}$ & : & & : & &  & 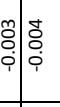 & $\mid \begin{array}{l}0 \\
0 \\
0 \\
\vdots \\
\end{array}$ & 望 & & ن. & 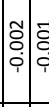 & & סִ & $\begin{array}{lll}\hat{0} & 0 \\
0 \\
0 \\
0 \\
0\end{array}$ & & 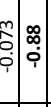 & 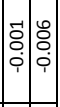 \\
\hline  & |l: & t. & 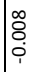 & $\begin{array}{ll}m & 0 \\
0 & 0 \\
0 & 0\end{array}$ & & :̊: &  & & & & 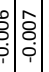 & '. & | &  & & P. & 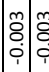 & & : & & &  & $\left.\mid \begin{array}{cc}\tilde{0} & m \\
0 & 0 \\
0 & 0 \\
0 & 0\end{array}\right]$ \\
\hline 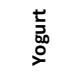 & | & 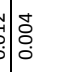 & 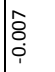 & 苛 & & :̂: & 웡영 & & & & 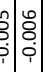 & 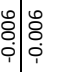 & 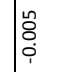 & & & : & & & : & & & 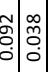 & 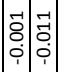 \\
\hline 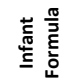 & 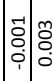 & : & 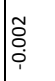 & & & 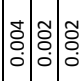 & 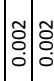 & & : & & : & ڤే: & 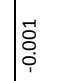 & & 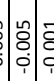 & ن. & 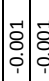 & & ڤִ & & & 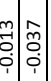 & 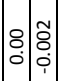 \\
\hline$\stackrel{\text { 坟 }}{ }$ & $\mid \begin{array}{l}|c| c \\
\vdots \\
\vdots\end{array}$ & bे & 荢 & $\left|\begin{array}{c}0 \\
0 \\
0 \\
0\end{array}\right| \tilde{c}$ & & $\left|\begin{array}{l}n \\
\vdots \\
0 \\
0\end{array}\right|$ & 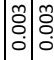 & : & : & & : & 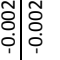 & |⿹ & & 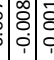 & to & 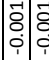 & & & 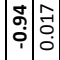 & 定 & 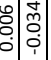 & $\begin{array}{ll}0 & 0 \\
0 & 0 \\
0 & 0 \\
\vdots & 0\end{array}$ \\
\hline 嵒 & 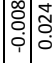 & : & |ֶ̊ & $\mid \begin{array}{l}\text { đ̊d } \\
\vdots \\
0\end{array}$ & & 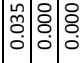 & 웅: & :3: & & & & 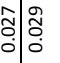 & ב̃ & : & & P. & $\left.\mid \begin{array}{l}0 \\
0 \\
0 \\
0\end{array}\right)$ & & : & : 80.0 & & : & 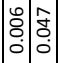 \\
\hline 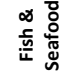 & $\mid \begin{array}{l}\infty \\
0 \\
0\end{array}$ & : & 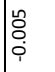 & & & & & & & & & ס̊: & $\mid \begin{array}{l}0 \\
0 \\
0\end{array}$ & & & ¿̊. & 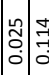 & & & $\stackrel{8}{\circ}$ & & $\begin{array}{lll} & 0 \\
& 0 & 0 \\
\end{array}$ & 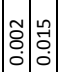 \\
\hline 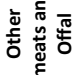 & 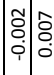 & s. & 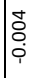 & $\hat{a}$ & & & : & & & & & 哭 & $\mid \begin{array}{l}0 \\
0 \\
0\end{array}$ & & & & 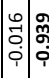 & & & & & & 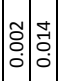 \\
\hline 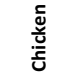 & 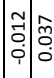 & b: & 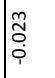 & 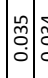 & & $\mid \begin{array}{l}0 \\
\hat{a} \\
0 \\
0\end{array}$ & : & : & & & & 卓 & $\mid \begin{array}{l}0 \\
0 \\
0 \\
0\end{array}$ & & & & 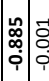 & & : & & 省 & : & 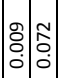 \\
\hline Фัँ & |l: & ț & : & 各 & & : & 잉: & ţ: ț: & : & & $\begin{array}{c}n \\
\vdots \\
0\end{array}$ & $\begin{array}{l}n \\
\vdots \\
0 \\
0\end{array}$ & oे & : & & $0^{\circ}$ & 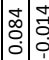 & & 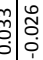 & & : & : $: 0$. & 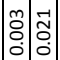 \\
\hline 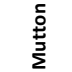 & 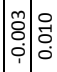 & : & |⿺辶一 & $\begin{array}{ll}0 \\
0 \\
0 \\
0\end{array}$ & & $\mid \begin{array}{l}n \\
0 \\
0 \\
0\end{array}$ & 앙융 & ș: & & & 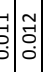 & $\begin{array}{c}\mid c \\
0 \\
0\end{array}$ & ờ & | & & & 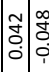 & & : & & 。 & & 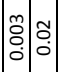 \\
\hline 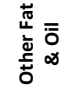 & 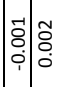 & : & $\begin{array}{l}\overrightarrow{0} \\
\vdots \\
i\end{array}$ & 领 & & $\left|\begin{array}{l}0 \\
0 \\
0 \\
0\end{array}\right|$ & $\overrightarrow{0}$ & ț: & s. & & : & 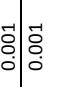 & 客 & 俑 & & | & 8 & & 8 & & c & |م: & o $0 \begin{array}{l}0 \\
\vdots \\
\vdots \\
\vdots\end{array} \mid$ \\
\hline $\begin{array}{l}\overline{\bar{o}} \\
\bar{E} \\
\bar{\xi}\end{array}$ & 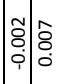 & : & 竞 & $\left|\begin{array}{l}0 \\
0 \\
0 \\
0\end{array}\right|$ & & : & శ్రం: & 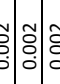 & & & : & ঠ் & 耪 & 龸 & & ș: & $\mid \begin{array}{l}0 \\
0 \\
0\end{array}$ & & $\begin{array}{c}0 \\
0 \\
0 \\
0\end{array}$ & & 1 & $\begin{array}{l}0 \\
0 \\
0\end{array}$ & $\mid \begin{array}{lll}0 & 0 \\
0 & 0 \\
0 & 0 \\
0 & 0\end{array}$ \\
\hline $\begin{array}{l}\overline{0} \\
\text { ă }\end{array}$ &  & :a & $\begin{array}{l}\infty \\
0 \\
0 \\
0 \\
i\end{array}$ & $\left|\begin{array}{c}\tilde{0} \\
0 \\
0\end{array}\right|$ & & &  & ț: & ț & & 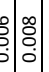 & : & 苂 & 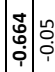 & î. & & $\mid \begin{array}{c}m \\
0 \\
0\end{array} 0 ة$ & & | & &  & & 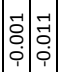 \\
\hline  & 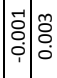 & s. & 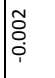 & $\mid \begin{array}{l}m \\
0 \\
0 \\
0 \\
0\end{array}$ & &  &  & ț: & s. & &  & 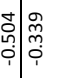 & †: & & :0 & & $\mid \begin{array}{l}\mid \vec{o} \\
\dot{0} \\
\dot{0}\end{array}$ & & : & & & \begin{tabular}{ll|l} 
& 0 \\
0 & 0 \\
0
\end{tabular} & $\begin{array}{lll}0 & 0 \\
0 & 0 \\
0 & 0 \\
0 & 0\end{array}$ \\
\hline 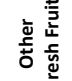 & 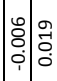 & : & F & $\mid \begin{array}{c}\infty \\
0 \\
0 \\
0\end{array}$ & & 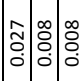 & $\overbrace{0}^{\infty}: \infty$ & 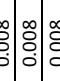 & 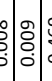 & & 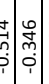 & 党: & $\begin{array}{l}\hat{n} \\
\hat{i} \\
\hat{i}\end{array}$ & & 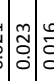 & & : & & & & & & $\left.\mid \begin{array}{l}0 \\
0 \\
0 \\
0\end{array}\right]$ \\
\hline 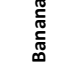 & 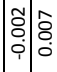 & : & $\begin{array}{l}\text { id } \\
0 \\
0 \\
0\end{array}$ & $\hat{a} \begin{array}{l}\hat{\partial} \\
0\end{array}$ & & : & $\mid$ & 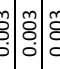 & 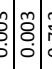 & & $\mid \begin{array}{lll}0 \\
0 \\
0 \\
0\end{array}$ & مَ & 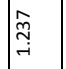 & 声 & $\mid \begin{array}{l}\mid \\
\vdots \\
0 \\
0 \\
0\end{array}$ & & $\mid \begin{array}{l}0 \\
\\
0\end{array}$ & & 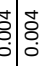 & : & & & $\begin{array}{l}0 \\
\vdots \\
0\end{array}$ \\
\hline \multirow[t]{2}{*}{ 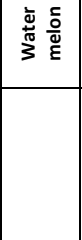 } & \begin{tabular}{l|l}
0 \\
0 \\
0 \\
\hdashline
\end{tabular} & לo & 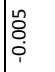 & 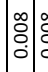 & & : & $\mid \begin{array}{l}\mid \\
0 \\
0 \\
0 \\
\end{array}$ & ț: & ţ & & 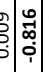 & 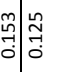 & $\underset{\substack{\tilde{Z} \\
0}}{0}$ & $\mid \begin{array}{l}0 \\
0 \\
0 \\
0\end{array}$ & 0 & & 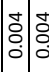 & & & 8. & & : & 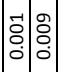 \\
\hline & 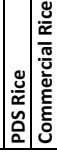 & 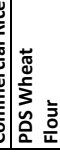 & 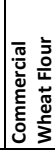 &  & & 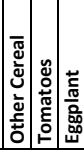 & & 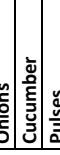 & & & & 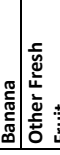 & 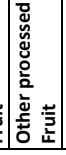 & 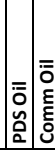 & 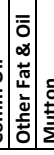 & & 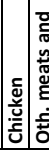 & 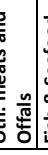 & 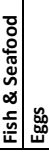 & 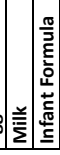 & & 竞 &  \\
\hline
\end{tabular}




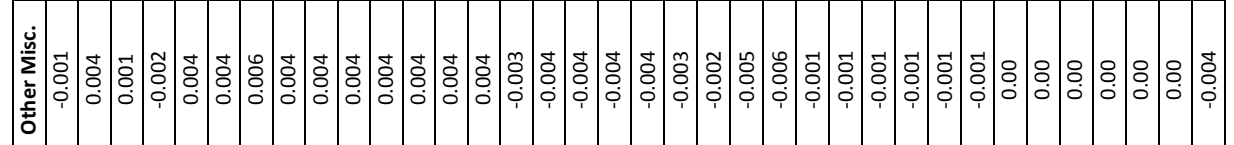

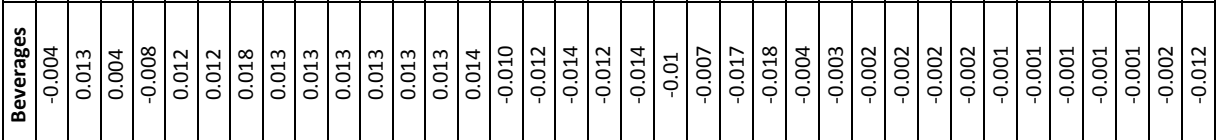

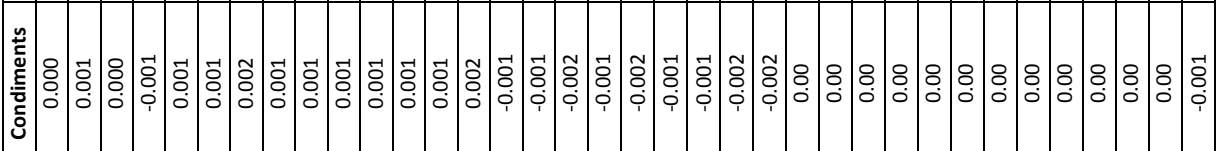

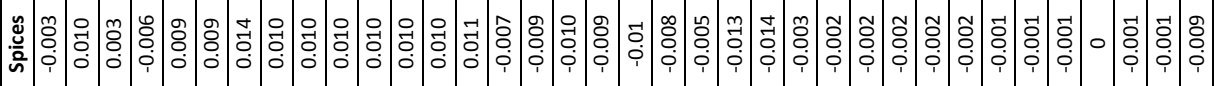

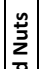

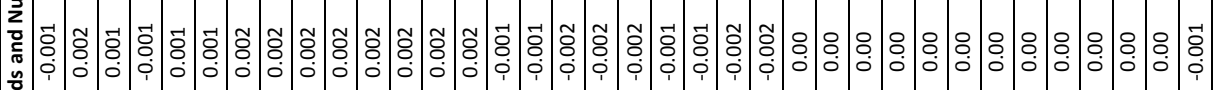
$\stackrel{\infty}{\leftrightarrow}$

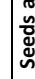

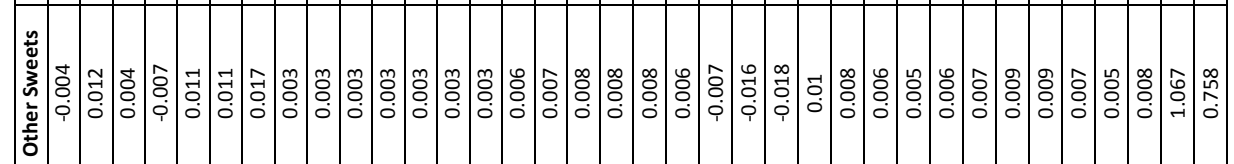

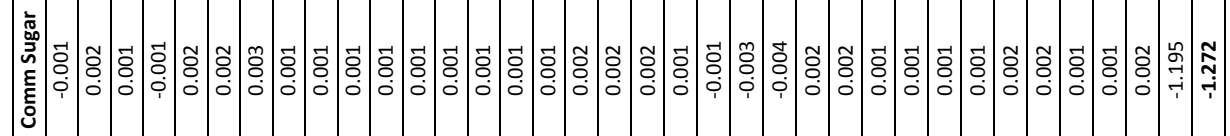

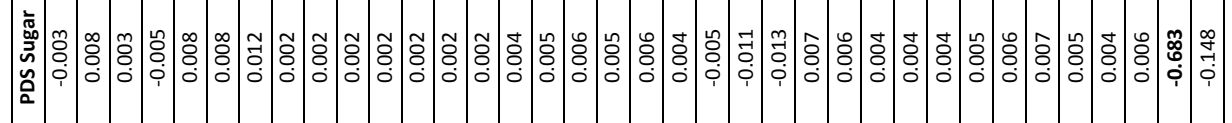

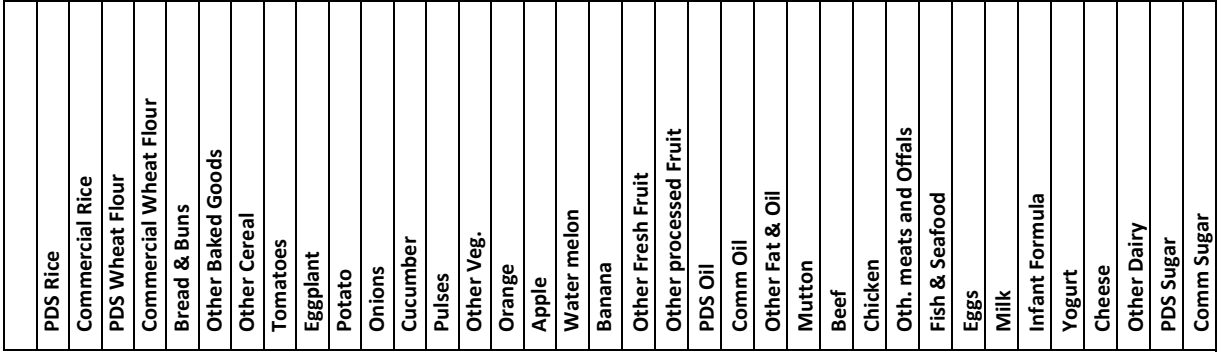




\section{Ex Ante Microsimulation of Food Security Policy Options}

\subsection{Introduction}

Successful design of social protection policies rests, in large part, on the ability to forecast the potential impact of the suggested policies. Knowing beforehand the positive impacts can help garner political support for the proposed policies and knowing the negative impacts is helpful in understanding and mitigating the political and social costs of the policies (Bourguignon \& Pereira da Silva, 2003).

This is also true for the successful design of food subsidy reform policies. Structural adjustment policies supported by international financial institutions, many of which incorporated reductions in food consumption subsidies, were associated with deteriorated food security (Devereux, 2016) and higher acute child malnutrition among the poorest in many African countries (Christiaensen, Demery, \& Paternostro, 2002) and other countries such as Jamaica (Handa \& King, 2003) or Sri Lanka (Sahn, 1987). Reactions to the effects of structural adjustment programs in the 1980s led to greater focus on mitigating the impact of reforms on poverty (Botchwey, Collier, Gunning, \& Hamada, 1998), effectively giving rise to World Banksponsored Poverty Reduction Strategies (Heidhues \& Obare, 2011).

For the poorest members of society food subsidies are an important safety net that ensures a minimally acceptable diet. Policy advise arguing for the elimination of generalized subsidies is invariably framed in terms of economic efficiency and cost containment (Sdralevich, Sab, Zouhar, \& Albertin, 2014). It is therefore natural that assessment of the impacts of food subsidy reform and designing mitigation measures to compensate the poorest members of society, financed by savings from the elimination of the subsidy, remain 
largely framed in economic terms. Even following evidence of deteriorating food security and nutrition as a result of food subsidy reform, the effects of reforms are understood as a loss of welfare to be mitigated by a cash transfers without sufficient understanding of the nutritional impact of eliminating the food consumption subsidies. Studies and research on food price subsidy regimes have somewhat ignored food security and nutrition impacts (Jensen \& Miller, 2008) and policy recommendations for the withdrawal of food consumption subsidies coupled with the scaling up of cash transfers, supported by poverty microsimulations, are near-ubiquitous in contexts such as Egypt (World Bank, 2005), Libya (IMF, 2013; Araar, Choueiri, \& Verme, 2015), Iraq (World Bank \& GOI, 2011) and India (World Bank, 2011).

The discussion in Chapter 1 highlights a trend whereby cash assistance has essentially become the default option for national social protection schemes as well as most response planning tools applied by International Organizations, particularly in contexts where markets are functioning. Published literature dealing with food subsidy reform and mitigation measures rarely include analysis of expected nutritional impacts of eliminating the subsidy or of the proposed mitigation measure or an analysis of the nutritional cost effectiveness of alternative mitigation measures. Indeed, it may not be a coincidence that in the contexts where relevant food and nutrient consumption analysis exists - namely the United States and India food consumption subsidies remain relatively popular and face no efforts, detectible in the literature, to scale back or monetize them ${ }^{53}$.

In Iraq, a joint World Food Programme (WFP) - Government of Iraq (GOI) report assessed the comparative nutritional cost effectiveness

53 See for example Kaul (2014) for India and Beatty \& Tuttle (2014) for the United States. 
analysis of cash and commodity based food voucher transfers using elasticities estimated from a reduced-form model (WFP \& GOI, 2012). The nutritional cost effectiveness analysis followed the Omega Value method typically applied by WFP when designing food assistance interventions. By design, the omega value enables the comparative cost effectiveness analysis of in-kind food transfers using different transfer mechanisms, such as direct distribution or the use of commodity based vouchers (Ryckembusch D. , et al., 2013). The analysis indicated that an expanded, more diverse food basket was nutritionally more cost effective than both the existing food basket provided by the Iraqi Public Distribution System (PDS) and a cash transfer alternative.

The Omega Value analysis succeeded in influencing the Government's PDS reform plans with the Iraqi parliament embarking on the process of crafting new legislation for the replacement of the current PDS paper voucher system, redeemed at specific food and flour agents, with an electronic voucher system that can be redeemed in the local markets (Iraqi Parliament, 2017). However, the draft law is ambiguous whether the food voucher will be commodity-based, such as that explored in the Omega Value analysis performed by WFP and the Government (WFP \& GOI, 2012) or it will be a value based voucher.

This chapter contributes to the debate surrounding the nutritional cost effectiveness of cash and food voucher transfer by undertaking an ex ante analysis of the welfare and food security effects of PDS reform using a static microsimulation model incorporating parameters from the Iraqi food demand system estimated in Chapter 4. Distributional, welfare and food security impacts of PDS reform are estimated and compared. Welfare effects are captured through Compensating Variation and simulated poverty headcount index, whereas food security effects are captured through the simulated change in macro and micronutrient consumption and simulated prevalence of undernourishment. 
In addition, cost effectiveness analysis of alternative mitigation efforts, including cash and value based food voucher transfers, is performed to determine the optimal parameters of post reform mitigation mechanisms that can be applied by the Government of Iraq. Relying on the results of Chapter 3, this paper demonstrates an approach to extend of the "Omega Value" Cost effectiveness analysis method applied by the World Food Programme to incorporate the possibility of undertaking comparative cost effectiveness analysis of cash and value based food voucher transfers.

The format of this paper is as follows. Section 2 links the typical objectives of food consumption subsidies to the theoretical food security framework and briefly elaborates the context of food consumption subsidies in Iraq. Section 3 defines the methodologies applied and data utilized the simulation of welfare and food security effects of reform and the ex-ante nutritional cost effectiveness analysis approach to compare cash and food vouchers. Results are presented in Section 4, including the expected effects of eliminating PDS subsidies on the cost of living and the associated food security and welfare effects. Section 4 also presents the comparative nutritional cost effectiveness analysis of cash and food voucher transfer schemes, ending with a simulation of the food security and welfare impacts of the considered transfer schemes. Section 5 includes a discussion of the broader implications of the findings, followed by concluding remarks in Section 6 .

\subsection{Theoretical Food Security Framework and the Iraqi Context}

Food Security exists when "all people, at all times, have physical, social and economic access to sufficient, safe and nutritious food to meet their dietary needs and food preferences for an active and 
healthy life" (World Food Summit, 2009). The pillars of Food Security - namely access, availability, utilization and stability reflect the different dimensions of the construct of food security (Committee on World Food Security, 2012) and provide angles from which food security can be measured and food insecurity can be addressed.

For example, a combination of poor local agricultural production as well as barriers to international trade may result in poor aggregate supply of food within a given country - which in this case would be considered to be experiencing food insecurity due to restricted availability of food. In contrast, even in contexts where aggregate supply is sufficient, income poverty may lead to restricted (economic) access to sufficient, safe and nutritious food for the poorest members of a given country - which would be considered to be experiencing food insecurity due to limited access to food. The stability pillar is a unique aspect of the food security construct that reflects vulnerability to fluctuations in availability or access to food, which not only influence the likelihood of rising acute food insecurity in the short term, but also influence long term food security through the effects of repeated shocks.

Food consumption subsidies typically include food security goals as they function as mechanisms to ensure the minimum acceptable food consumption for its intended beneficiaries and as income transfer mechanisms (Pistrup-Andersen \& Alderman, 1988). The Iraqi food consumption subsidy regime, commonly known as the Public Distribution System (PDS), is one of the last remaining universal regimes of its kind. The origin of the PDS as a food rationing regime was a direct result of restricted availability of food in Iraq following the imposition of UN sanctions in 1990 (UN Security Council, 1990). Soon after the 2003 War and the fall of the Baathist regime, many of the institutions in place prior to the war, including the PDS, fell under 
review for dismantlement or reform by the coalition provisional authority (WFP, 2004).

The continuation of the PDS following the lifting of sanctions in 2003 transformed the main function of the PDS from a rationing mechanism into a food consumption subsidy. To this day, the Government of Iraq continues to bear the full responsibility of procurement, supply chain management and distribution of food rations to nearly all Iraqi families.

As food consumption guarantee mechanisms, subsidies allow access to food at fixed, low prices, often shielding its recipients from inflation and volatility in food prices. This is the case in Iraq, where the PDS rations are still purchased today at nominal prices set in the early 1990s - thereby ensuring the stability of food consumption for the Iraqi population during and after the period of hyperinflation starting in 1991 (UN, 1991) and by all accounts spared the Iraqi population widespread hunger during the period of international sanctions (World Bank, 2007). In the immediate aftermath of the soaring global food prices in 2008, a UN report asserted that the PDS shielded the Iraqi population from the worse effects of soaring global food prices, though this burden fell on the public coffers - where the budget for the PDS grew to US\$5.9 billion, up from US\$3.6 billion in the previous year (FAO \& IAU, 2009).

Food consumption subsidies also function as income transfer mechanisms (Pistrup-Andersen \& Alderman, 1988). By keeping consumer prices low, the income transfer is essentially the difference between the value of consumed subsidized goods and what they would pay if they were to purchase the food at unregulated market prices. Given that virtual prices represent the price levels reflecting consumption levels of PDS goods, the difference between the market price of free market equivalents of the PDS goods and the virtual price of the PDS goods can be considered as an indirect virtual tax. Adapting from Cornielje's definition of virtual tax (1985), for a set of 
rationed goods $z_{k}, k=1, \ldots, N$, their virtual prices $p_{k}^{*}$ and the market price of their free market equivalents $p_{k}$, the virtual tax rate $\left(t_{k}\right)$ is defined as $t_{k}=\left(p_{k}^{*}-p_{k}\right) / p_{k}^{*}$, thereby producing a schedule of negative indirect tax rates, as is normally the case with subsidies (Capéau, Decoster, \& Phillips, 2014). The implied virtual total lumpsum income transfer due to the subsidy $(\lambda)$ is estimated as $\lambda=$ $\sum_{k=1}^{n}\left(p_{k}-p_{k}^{*}\right) z_{k}$.

Eliminating PDS subsidies, therefore, is analogous to the introduction of an indirect tax equal to the negative of the virtual tax rate $\left(t_{k}\right)$ leading to the erosion of the real value of income or consumption expenditure, the impacts of which can be assessed using typical static indirect tax microsimulation modelling approaches (Capéau, Decoster, \& Phillips, 2014).

World Bank microsimulations performed using household survey data from 2007 indicated that a sudden, unmitigated elimination of the PDS would lead to an increase in poverty rates from 22.9 to 34.4 percent if prices remain the same and up to 40.3 percent if prices double. A perfectly targeted, cash transfer instituted to mitigate the impact of the elimination of the PDS on poor Iraqi households was simulated to all but eliminate poverty, bringing it down to an impressive 4.5 percent under the assumption that prices of free market goods remain unchanged (World Bank \& GOI, 2011). At a time when government of expenditures on the PDS almost doubled due to the global food price crisis in 2007-2008 (FAO \& IAU, 2009), the prospect of achieving the twin objectives of reigning in expenditures on the PDS and tackling poverty encouraged the Government of Iraq to approve a plan to gradually limit eligibility to benefit from the PDS subsidy until only those under the poverty line remain eligible and to finally replace the subsidy with a direct cash transfer (GOI, 2009). 
Similarly, WFP and Government of Iraq, using the same household survey data from 2007, applied a basic, reduced form calorie elasticity to simulate the impact of eliminating the PDS on calorie consumption and the prevalence of undernourishment. The simulation concluded that the prevalence of undernourishment would increase from 7.1 to 14 percent using the 2007 data. The same simulation applied to similar household survey data from 2011 simulated an increase in undernourishment from 5.7 up to 9 percent (WFP \& GOI, 2012).

\subsection{Methodology and Data}

Using the demand system parameters estimated in Chapter 4, this paper will assess the effects of PDS reform on welfare and food security where welfare effects are estimating using Compensating Variation and the simulated poverty headcount index, whereas food security effects are assessed by examining the change in macro and micro nutrient consumption and the simulated prevalence of undernourishment. Once the effects are simulated, the comparative nutritional cost effectiveness of alternative mitigation measures is assessed.

\section{Welfare Effects}

Welfare changes resulting from PDS subsidy reform will be captured through Compensating Variation (CV) and simulated poverty headcount index. CV is a monetary measure of welfare loss (gain) resulting from an increase (decrease) in prices facing consumers and is regularly applied in the relevant literature (see for example: (Minot \& Goletti, 2000; Friedman \& Levinsohn, 2002; Niimi, 2005; Ackah 
\& Appleton, 2007; Ramadan \& Thomas, 2011)). In its most abstract form, $\mathrm{CV}$ is expressed as

$$
C V=c\left(u, \boldsymbol{p}^{\mathbf{1}}\right)-c\left(u, \boldsymbol{p}^{\mathbf{0}}\right)
$$

where $c($.$) is the minimum cost function for achieving utility level$ (u) given a price vector $(\boldsymbol{p})$ and where the superscripts 0 and 1 denote pre and post reform conditions respectively.

To benefit from the food demand system parameters estimated in Chapter 4, the specification applied in this present paper draws on the specification of Capéau, Decoster \& Phillips (2014), which is specific to QUAIDS models, where $c\left(u, \boldsymbol{p}^{\mathbf{t}}\right)$ is estimated as

$$
c\left(u, \boldsymbol{p}^{\mathbf{t}}\right)=P\left(\boldsymbol{p}^{\mathbf{t}}\right) \exp \left(\left(b\left(\boldsymbol{p}^{\mathbf{t}}\right)\left[\frac{1}{\ln u}-\lambda\left(\boldsymbol{p}^{\mathbf{t}}\right)\right]^{-1}\right)\right.
$$

where $\boldsymbol{p}^{\mathbf{t}}$ is the price vector before $(t=0)$ and after $(t=1)$ reform. $b\left(\boldsymbol{p}^{\mathbf{t}}\right)$ and $P\left(\boldsymbol{p}^{\mathbf{t}}\right)$ are the price indices specified in Eqs. (11) and (12) in Chapter 4. Baseline utility level $(\ln u)$ is represented by the indirect utility function $(\ln V)$, which for the QUAIDS model is

$$
\ln V=\left\{\left[\frac{\ln m-\ln P\left(\boldsymbol{p}^{\mathbf{0}}\right)}{b\left(\boldsymbol{p}^{\mathbf{0}}\right)}\right]^{-1}+\lambda\left(\boldsymbol{p}^{\mathbf{0}}\right)\right\}^{-1}
$$

with $\lambda\left(\boldsymbol{p}^{\mathbf{0}}\right)$ equal to

$$
\lambda\left(\boldsymbol{p}^{\mathbf{0}}\right)=\sum_{i=1}^{n} \lambda_{i} \ln p_{i}
$$

However, given the multi stage budgeting approach taken in estimating the food demand system, the CV specified in Eq. (1) is estimated separately for price increases in cereals (rice and wheat 
flour), vegetable oil and sugar due to PDS reform ${ }^{54}$. To ensure the adequate estimation of $\mathrm{CV}$, the process is slightly modified by first defining a food specific $\mathrm{CV}$ ratio $\left(C V R_{\text {food }}\right)$ as

$$
C V R_{\text {food }}=\frac{\sum_{k=1}^{n} C V_{k}}{m_{f}}
$$

where $\mathrm{k}=1, \ldots, 3$ food groups that include PDS commodities - namely Cereals, Oils and Sugars - with $C V_{k}$ estimated as specified in Eqs. (1) through (4) and where $m_{f}$ is total food expenditure. Accordingly, $C V R_{\text {food }}$ reflects the percent increase in food expenditure required to maintain pre PDS reform utility levels. Finally, the overall CV ratio is estimated by applying the overall expenditure elasticity of demand for food $(\eta)$ as specified in Eq. (8) in Chapter 4, such that

$$
C V R=\frac{C V R_{\text {food }}}{\eta}
$$

where $C V R$ reflects the proportional increase in total expenditure required to maintain pre PDS reform utility levels. To assess the distributional effect of PDS reform, CVR is estimated separately for each expenditure decile. Aside from measuring welfare effects, CVR is useful in the Iraq context if it is taken to estimate the transfer value of the compensation required to mitigate the impacts of the simulated reforms.

The impact of PDS reform on the prevalence of poverty is simulated through an approach similar to that applied by the World Bank

\footnotetext{
${ }^{54}$ Given the separate estimation of CV it is possible that this measure of CV underestimates the full welfare cost since PDS goods are substitutes. However, the alternative of estimating CV at the food group level (Stage 2 model in Chapter 4) would not capture the extent of welfare loss given the fact that PDS Wheat Flour and PDS Rice are within the same food group (Cereals and Cereal Products).
} 
previously in Iraq (World Bank \& GOI, 2011) as well as in other contexts, such as Libya (Araar, Choueiri, \& Verme, 2015), which essentially entails reflecting the increased cost of living as a loss in the real value of observed expenditure. The poverty measure used here is the poverty headcount ratio according to Foster, Greer and Thorbeck (Foster, Greer, \& Thorbecke, 1984), defined as

$$
P_{\alpha}=\frac{1}{N} \sum_{i=1}^{N}\left(\frac{z-y_{i}^{*}}{z}\right)^{\alpha}
$$

where $N$ is the survey sample size, $z$ is the poverty line, $y_{i}$ is consumption expenditure ${ }^{55}$ and $\alpha$ is a parameter that is given the value 0 for the poverty headcount, and 1 and 2 for poverty gap and poverty severity respectively.

For the microsimulation, the poverty line $(z)$ is inflated by the expected growth in the cost of living ${ }^{56}$ for the second and third poorest deciles - which are the two reference deciles used by the Word Bank and Government of Iraq to define the food poverty line. To simulate the effect of any mitigation measures, nominal household expenditure is increased for the targeted groups in accordance with the estimated CVR as defined in Eq. (6) above.

The fact that the measure of change in the cost of living used to adjust the poverty line accounts for expected changes to consumption induced by PDS reform, coupled with the fact that the rate applied refers specifically for the reference group used in designing the

55 The * superscript in Eq. (7) denotes that the vector $y_{i}$ is censored at the poverty line.

56 To estimate growth in the cost of living, this paper utilizes the transcendental logarithmic price index elaborated below (see Eq. 15). 
poverty ensures that the simulation avoids what Bourguignon et al. (2006) describe as a "pure accounting" simulation.

\section{Food Security Effects}

The measure of undernourishment used in this paper follows the Food and Agriculture Organization (FAO) method, which is based on the distribution of dietary energy consumption (DEC) and the sustainable development goal for hunger. The FAO defines the prevalence of undernourishment $\left(P_{U}\right)$ within a population as the probability of an individual in the population having dietary energy consumption $(x)$ less than the minimum dietary energy requirements $\left(r_{L}\right)$ under the assumption of a lognormally ${ }^{57}$ distributed $x$ (Sibrian, Ramasawmy, \& Mernies, 2007). This is specified as

$$
P_{U}=\phi\left(\frac{\ln \left(r_{L}\right)-\mu_{x}}{\sigma_{x}}\right)
$$

Where $\phi$ is the standard normal cumulative distribution function. The average dietary energy consumption $\left(\mu_{x}\right)$ is calculated, in log scale, as

$$
\mu_{x}=\ln (\bar{x})-\frac{\left[\sqrt{\ln \left(V_{x}^{2}+1\right)}\right]^{2}}{2}
$$

with $\bar{x}$ being the population arithmetic mean dietary energy consumption calculated as

\footnotetext{
${ }^{57}$ The recent change of the assumption of lognomality in the FAO method to include skew-normal and log skew-normal is not applied here as the skewness parameter for dietary energy consumption in the population exceeds the limit set by FAO. See Cafiero (2014) for more information.
} 


$$
\bar{x}=\sum_{d=1}^{10} f_{d} \overline{x_{d}} / \sum_{d=1}^{10} f_{d}
$$

and $V_{x}$ is the coefficient of variation of dietary energy consumption defined by the FAO method to reflect both inequality in consumption due to biological factors ${ }^{58}\left(V_{x \mid r}\right)$ and inequality in consumption due to income $\left(V_{x \mid v}\right)$. The FAO definition of $V_{x \mid v}$ therefore captures the inequality in dietary energy consumption by income (or expenditure) decile distilled of other inequality inducing factors and is estimated as

$$
V_{x \mid v}=\frac{\sigma_{x \mid v}}{\bar{x}}
$$

Where $\sigma_{x \mid v}$ is the standard deviation of dietary energy consumption due to income estimated as

$$
\sigma_{x \mid v}=\sqrt{\left[\sum_{d=1}^{10} f_{d}{\overline{x_{d}}}^{2}-\left(\sum_{d=1}^{10} f_{d} \overline{x_{d}}\right)^{2} / \sum_{d=1}^{10} f_{d}\right] /\left(\sum_{d=1}^{10} f_{d}-1\right)}
$$

with $f_{d}$ representing the number of sampled households falling in the $\mathrm{d}^{\text {th }}$ decile and $\overline{x_{d}}$ the mean per person daily calorie consumption for the $\mathrm{d}^{\text {th }}$ decile.

Although intra household inequality in consumption is likely to be a significant factor for individual level consumption analysis, the FAO approach does not yet provide the facility to fully account for it. Although intra-household variability in consumption is difficult to capture through household surveys, it is unclear whether the current FAO measure of undernourishment would have the facility to account

\footnotetext{
${ }^{58}$ Biological factors includes sex, age, physical activity level and weight. This is a constant set at approximately 0.183 (Sibrian, Ramasawmy, \& Mernies, 2007).
} 
for it even if it were properly captured - largely due to the parametric approach to measurement. However, this is at least partially addressed for through accounting for inequality in consumption due to biological factors $\left(V_{x \mid r}\right)$ where the final coefficient of variation is given by $\sqrt{\left(V_{x \mid r}\right)^{2}+\left(V_{x \mid v}\right)^{2}}$.

Minimum dietary energy requirements $\left(r_{L}\right)$ are calculated according to the FAO method (see Sibrián et al. (2007) for technical details) as the weighted average of the minimum calories required to maintain minimally acceptable weights given attained height ${ }^{59}$ for each sex and age group - weighted by the proportion of each sex and age group from the total Iraqi population.

In their analysis of household behavior under rationing, Neary and Roberts found that "an increase in the price of rationed goods has an income effect only" (Neary \& Roberts, 1980, p. 34). Similarly, Huang and Lin (2000) apply nutrient expenditure elasticities in measuring the effect of Food Stamps on food consumption and Anriquez, Daidone and Mane (2013) estimated change in food consumption due to rising global food prices between 2005 and 2008 as directly due to change in real income. This is also following the present paper to simulate the effect of PDS reform on undernourishment.

Accordingly, keeping nominal expenditure constant and specifying change in nutrient intake due to price variations as resulting from change in real expenditures, the simulated nutrient intake is estimated as

$$
\frac{d x}{x}=\rho_{x} \cdot \frac{d y}{y}
$$

\footnotetext{
59 assuming a sedentary physical activity level for adults.
} 
where $\rho_{x}$ is the $\mathrm{x}^{\text {th }}$ nutrient conditional expenditure elasticity as defined in Eq. 27 in Chapter 4. Conditional elasticities are applied drawing on the conclusions reached in Chapter 3, where food demand elasticity due to food transfers are estimated at approximately 1 across all deciles.

Change in total real consumption expenditure $(d y / y)$ following reform is calculated as the budget share weighted average change in the cost of the 8 food groups for which demand elasticities are estimated in Chapter 4. The food groups are (i) Cereals including cereal products such as bread, (ii) Vegetables \& Pulses including vegetable products such as canned vegetables, (iii) Fruits including preserved fruits, (iv) Oils \& Fats, (v) Fish, Meat \& Eggs, (vi) Milk \& dairy products, (vii) Sugars \& Syrups and (viii) Miscellaneous foods. Since only the Cereals, Oil and Sugars food groups include PDS goods, they will account for the entirety of change in the cost of living and other food groups as well as non-food prices are assumed to remain constant. Assuming constant nominal expenditure, change in total real consumption equals the change in cost of living, defined as

$$
\frac{d y}{\mathrm{y}}=\sum_{i=1}^{K} w_{i}^{*}\left(e^{(d \ln P(\boldsymbol{p}))}-1\right)
$$

where $\ln P(\boldsymbol{p})$ is the transcendental logarithmic price index integral to the QUAIDS demand model (Banks, Blundell, \& Lewbel, 1997), estimated as

$$
\ln P(\boldsymbol{p}) \equiv \alpha_{0}+\sum_{i=1}^{K} \alpha_{i} \ln p_{i+} \frac{1}{2} \sum_{i=1}^{K} \sum_{j=1}^{K} \gamma_{i j} \ln p_{i} \ln p_{j}
$$

where $p_{i}$ is the price of the ith subgroup from a total of 42 subgroups included in third budget stage of the food demand model estimated in Chapter 4. The parameter $\alpha_{0}$ is predetermined, as specified in 
Chapter 4 and $\alpha_{i}$ and $\gamma_{i j}$ are parameters estimated during the estimation of the QUAIDS models, reported for each of the 8 food groups in Appendix 2 in Chapter 4. This choice of price index is similar to the choice of a superlative price index reflecting the cost of living where the $\alpha_{i}$ 's reflect the income effect of a price change, and the substitution effect captured in $\gamma_{i j}$ 's reflect the effect of relative price changes. In addition, the star superscript for the budget shares $\left(w_{i}^{*}\right)$ indicate the use of simulated budget shares, updated to reflect the effects of price changes using budget share elasticities ${ }^{60}$.

Following the suggestion of Anriquez et al. (2013), the effects of price changes on undernourishment are simulated not only through changes in mean calorie consumption but also through changes in inequality in calorie consumption. Accordingly, mean calorie consumption is simulated for each decile given Eq. (8). Finally, adjusting the $\mu_{x}$ and $\sigma_{x}$ parameters in Eq. (3) accounting for the simulated calorie consumption produces a ceteris paribus simulation of the impact of policies on the prevalence of undernourishment.

Simulated post reform nutrient intake for all nutrients considered in this study are estimated in a similar fashion and mean consumption of all nutrients are presented nationally and by decile. Nutritional deprivation analysis is limited in this paper to calorie consumption only.

${ }^{60}$ Given that Edgerton (1997) does not offer a specification for deriving unconditional budget share elasticities from multistage demand systems, this paper relies on Eq. (18) in Chapter 4 to estimate implied unconditional budget share elasticities relative to prices $\frac{\partial w_{i}}{\partial \ln p_{j}}=E_{i j} w_{i}+\delta_{i j}$, where $E_{i j}$ is the unconditional second stage price elasticities and $\delta_{i j}$ is Kronecker's delta taking the value 1 when $i=j$ and 0 otherwise. 
Nutritional cost effectiveness analysis

To consider alternative policies to mitigate the effects of PDS reform and tariffs, this paper extends the ex-ante nutritional cost effectiveness analysis approach typically applied by WFP, to incorporate the ability to compare the effectiveness of cash and food voucher transfers. This approach, referred to as the Omega Value, estimates the cost per aggregate nutrient unit supplied by the transfer (WFP, 2014). Ryckembush et al. (2013) present the Omega Value as a means to go beyond cost efficiency measures when determining assistance modalities through incorporating a "nutrient per dollar" perspective in the design of transfer mechanisms addressing food insecurity.

The Omega value $(\Omega)$ is a ratio of two values where both numerator and denominator are the ratio of nutrient value delivered by a food assistance programme relative to its total cost. As such, $\Omega$ evaluates the nutrient delivery per dollar investment of two food assistance programmes and is estimated as

$$
\Omega=\frac{N V S^{b} / \operatorname{Cost}^{b}}{N V S^{a} / \operatorname{Cost}^{a}}
$$

where $\operatorname{Cost}^{a}$ represents the total cost of undertaking programme "a". $N V S^{a}$ is the Nutrient Value Score for the food basket expected in programme "a", which is the sum of the proportion of nutrient specific daily requirements provided in the food basket. The typical estimation of the NVS truncates this proportion at unity (i.e. when a basket meets $100 \%$ or more of the daily requirements), though this is not performed in the present paper. Truncating the proportion of nutrient intake requirements that is met due to the transfer penalizes transfers that exceed nutritional recommendations. However, most nutritional recommendations refer to suggested average consumption 
and very few nutritional recommendations offer a perspective on what maximum consumption should be. In the context of this paper, the level of consumption due to the transfer is estimated using nutrient elasticities, which are determined by consumer preferences. The view taken in this paper is that it is preferable simply to estimate the NVS as the sum of the proportion of nutrient specific daily requirements provided in the food basket without truncation. This is calculated through

$$
N V S=\sum_{1}^{k} \frac{C^{k}}{R^{k}}
$$

where $C^{k}$ is the expected consumption of the $\mathrm{k}^{\text {th }}$ nutrient due to the transfer and $R^{k}$ is the recommended intake of the $\mathrm{k}^{\text {th }}$ nutrient. Accordingly, $\Omega<1$ implies that the base food assistance programme (Programme "a") is nutritionally more cost effective than the alternative (Programme " $b$ ").

In their presentation of the Omega value methodology and its limitations, Ryckembusch et al. (2013) note that the methodology is applied only to compare the delivery of actual food baskets (such as food aid parcels) with varying compositions. This study demonstrates the use of the Omega value method to determine the nutritional cost effectiveness of cash transfers and food vouchers ${ }^{61}$. This is performed using nutrient demand elasticities exactly as specified in Eq. (8) with the change in expenditure $(d y / y)$ is a result

\footnotetext{
${ }^{61}$ Unless specified otherwise, all references made in this paper to food vouchers refer to "value based" food voucher, which provides the recipient with a fixed monetary value dedicated to the acquisition of food with no, or very few, restrictions on the choice of food basket or quantities. The Supplemental Nutrition Assistance Programme (SNAP) in the United States is an example of a value based voucher.
} 
of the nominal value of the transfer. However, recalling the analysis presented in Chapter 3 where demand for food due to food assistance is found to be unit elastic, nutrient elasticities applied in simulating the nutrient demand due to food vouchers are estimated using conditional demand elasticities. The typical unconditional nutrient expenditure elasticities are applied when simulating nutrient consumption due to cash transfers.

\section{Data Sources}

As in the previous chapter, this paper also utilizes the 2012 Iraq Household Socio Economic Survey (IHSES) data, with a total sample of 25,142 households and representative at the national, province and district levels. The IHSES questionnaire includes a diary for food and recurrent non-food expenditures and a recall for non-recurrent non-food expenditures and for PDS food items. Data on acquired food quantities are converted into nutrient availability after adjusting weights by excluding non-edible portions. Accordingly, household level nutrient availability is estimated for a total of 10 nutrients including protein, carbohydrate, fat, fiber, alcohol, iron, zinc, folate, vitamin A and vitamin B12, plus kilocalorie availability which is calculated directly from the macronutrients ${ }^{62}$.

Prevalence of undernourishment in 2012, calculated according to the method outlined above in Eqs. (3) through (7), is estimated at 4.78 percent, with the national mean dietary energy consumption estimated at 3,065 kilocalories per person per day and a coefficient of variation in calorie consumption of 0.308 . This is an improvement on the 2011

\footnotetext{
${ }^{62}$ See Chapter 4 for further details on data and data manipulations.
} 
prevalence, which was reported at 5.7 percent overall (WFP \& GOI, 2012).

Using the 2012 IHSES survey as well, the World Bank estimate poverty at 19.8 percent (World Bank, 2014a). The large discrepancy between the prevalence of poverty and undernourishment can be attributed both to methodological differences as well as to the importance of the PDS in ensuring food consumption. Methodologically, the poverty line for Iraq follows the cost of basic needs approach. The food poverty line estimates the cost of acquiring average dietary energy requirements - estimated by the World Bank for Iraq at 2,337 kilocalories per person per day. The prevalence of undernourishment, however, estimated the proportion of the population with calorie consumption less than the minimum dietary energy requirements, estimated at 1,775 kilocalories per person per day.

Aside from the above, it is evident that the PDS plays a significant role in ensuring food consumption in Iraq. This is perhaps best illustrated by the significant differences in the budget shares and dietary energy shares of the PDS food items listed in Table 1.

Table 1: Calorie and Food Budget Shares for PDS commodities

\begin{tabular}{lcc} 
& Calorie Share & Food Budget Share \\
\cline { 2 - 3 } PDS Rice & $7.8 \%$ & $0.7 \%$ \\
PDS Wheat Flour & $28.5 \%$ & $3.0 \%$ \\
PDS Vegetable Oil & $7.4 \%$ & $1.3 \%$ \\
PDS Sugar & $6.9 \%$ & $1.3 \%$ \\
Total & $50.7 \%$ & $6.3 \%$ \\
\hline
\end{tabular}

Source: Own estimations using IHSES 2012

On average, PDS food commodities provide over 50 percent of total calories acquired by Iraqi households. Yet, when estimated with virtual prices - which are generally higher than the actual paid 
amounts - expenditures on PDS foods consumes only 6.3 percent of total expenditure on food.

As virtual prices reflect the price level that coincides with observed consumption levels, poorer households that consume more of the subsidized goods and less of the more expensive free market equivalents face lower virtual prices for the subsidized goods. Accordingly, poorer households face greater (negative) tax rates than wealthier households (Table 2).

Table 2: Indirect Tax Rate and Income Transfer Due to PDS Subsidies

\begin{tabular}{|c|c|c|c|c|c|c|}
\hline & \multicolumn{2}{|c|}{ Income Transfer } & \multicolumn{4}{|c|}{ Indirect Tax Rate } \\
\hline & $(\%)$ & $\begin{array}{c}\text { (\$/mont } \\
\mathrm{h})\end{array}$ & $\begin{array}{l}\text { PDS } \\
\text { Rice }\end{array}$ & $\begin{array}{l}\text { PDS } \\
\text { Wh. } \\
\text { Flour }\end{array}$ & $\begin{array}{c}\text { PDS } \\
\text { Veg. Oil }\end{array}$ & $\begin{array}{l}\text { PDS } \\
\text { Sugar }\end{array}$ \\
\hline Vational & $4.9 \%$ & 47.4 & $-609 \%$ & $-350 \%$ & $-2834 \%$ & $-2388 \%$ \\
\hline Decile 1 & $16.5 \%$ & 72.0 & $-708 \%$ & $-511 \%$ & $-3757 \%$ & $-4376 \%$ \\
\hline Decile 2 & $11.3 \%$ & 71.4 & $-681 \%$ & $-566 \%$ & $-3385 \%$ & $-4217 \%$ \\
\hline Decile 3 & $8.0 \%$ & 60.7 & $-576 \%$ & $-366 \%$ & $-2902 \%$ & $-2957 \%$ \\
\hline Decile 4 & $6.8 \%$ & 56.3 & $-733 \%$ & $-387 \%$ & $-5364 \%$ & $-3279 \%$ \\
\hline Decile 5 & $5.3 \%$ & 47.5 & $-539 \%$ & $-319 \%$ & $-3275 \%$ & $-1982 \%$ \\
\hline Decile 6 & $4.3 \%$ & 42.2 & $-605 \%$ & $-267 \%$ & $-3449 \%$ & $-1891 \%$ \\
\hline Decile 7 & $3.7 \%$ & 40.0 & $-542 \%$ & $-296 \%$ & $-1735 \%$ & $-1557 \%$ \\
\hline Decile 8 & $2.8 \%$ & 34.2 & $-595 \%$ & $-228 \%$ & $-2299 \%$ & $-1817 \%$ \\
\hline Decile 9 & $2.1 \%$ & 28.7 & $-483 \%$ & $-233 \%$ & $-1669 \%$ & $-1577 \%$ \\
\hline Decile 10 & $1.2 \%$ & 21.3 & $-532 \%$ & $-183 \%$ & $-1690 \%$ & $-1462 \%$ \\
\hline
\end{tabular}


Table 2 also lists the estimated lump-sum income transfer due to the subsidy as a proportion of total expenditures and in 2012 dollar terms. The PDS income transfer is progressive falling from 16.5 percent of total expenditure for the poorest decile down to 1.2 percent for the wealthiest decile.

Aside from survey data, additional information is required to complete the analysis for this paper - namely nutrient expenditure demand elasticities. These are listed in Table 8 of Chapter 4 and repeated in the table below for ease of reference.

\section{Table 3: Nutrient Expenditure Elasticities $\left(\rho_{k}\right)$ Nationally and by Decile}

\begin{tabular}{llllllllll} 
& Calories & Protein & Fat & $\begin{array}{l}\text { Carbo- } \\
\text { hydrates }\end{array}$ & Iron & Zinc & Folate & $\begin{array}{l}\text { Vit. } \\
\text { A }\end{array}$ & $\begin{array}{l}\text { Vit. } \\
\text { B12 }\end{array}$ \\
\cline { 2 - 10 } National & 0.507 & 0.524 & 0.762 & 0.399 & 0.480 & 0.514 & 0.668 & 0.753 & 0.896 \\
Decile 1 & 0.325 & 0.346 & 0.602 & 0.237 & 0.321 & 0.313 & 0.623 & 0.876 & 0.917 \\
Decile 2 & 0.382 & 0.419 & 0.660 & 0.283 & 0.388 & 0.391 & 0.642 & 0.821 & 0.894 \\
Decile 3 & 0.430 & 0.458 & 0.706 & 0.324 & 0.417 & 0.441 & 0.650 & 0.789 & 0.902 \\
Decile 4 & 0.442 & 0.473 & 0.722 & 0.329 & 0.438 & 0.456 & 0.657 & 0.772 & 0.892 \\
Decile 5 & 0.481 & 0.498 & 0.748 & 0.372 & 0.448 & 0.480 & 0.658 & 0.749 & 0.889 \\
Decile 6 & 0.509 & 0.519 & 0.769 & 0.399 & 0.474 & 0.503 & 0.665 & 0.736 & 0.880 \\
Decile 7 & 0.552 & 0.553 & 0.800 & 0.443 & 0.502 & 0.553 & 0.673 & 0.714 & 0.905 \\
Decile 8 & 0.577 & 0.570 & 0.818 & 0.468 & 0.525 & 0.569 & 0.679 & 0.688 & 0.886 \\
Decile 9 & 0.627 & 0.602 & 0.837 & 0.529 & 0.559 & 0.606 & 0.679 & 0.663 & 0.861 \\
Decile 10 & 0.684 & 0.642 & 0.857 & 0.602 & 0.595 & 0.660 & 0.676 & 0.613 & 0.858 \\
\hline
\end{tabular}

Source: Chapter 4

In addition, the matrix of compensated price elasticities is required in order to estimate welfare effects of PDS reform using Compensating Variation $(\mathrm{CV})$. In order to allow for varying welfare effects across the wealth distribution, a matrix of compensated price elasticities 
estimated for each decile separately is required ${ }^{63}$. Using this information and following the methods described above, the impact of PDS reform on welfare and food security is estimated and reported below.

\subsection{Results}

\subsubsection{Impact of PDS Reform on Welfare}

PDS subsidies provide nearly all Iraqi households with access to a ration of basic food commodities at extremely low prices. Therefore, eliminating PDS subsidies in a reform process would necessarily lead to significant increases in prices and a loss in the real value of expenditures. This is further amalgamated by the expected increase in the price of free market equivalents of PDS goods (such as commercial wheat flour). The increase in cost of living ${ }^{64}$ is estimated following Eq. (14) relying on price indices for each of the 8 food groups as defined in Eq. (15). These are reported in Table 4 below.

${ }^{63}$ Each of these is a $42 \times 42$ matrix, thereby precluding the ability to include in the report or an appendix. They are available upon request from the authors.

64 The overall price index was calculated using all 8 food groups using data from all 42 food items included in the third stage demand models estimated in Chapter 4. Non-food goods are included, although no change in prices of non food goods is assumed. These are not listed in the table due to space considerations. 
Table 4: Increase in Prices and Overall Cost of Living Due to PDS Reform

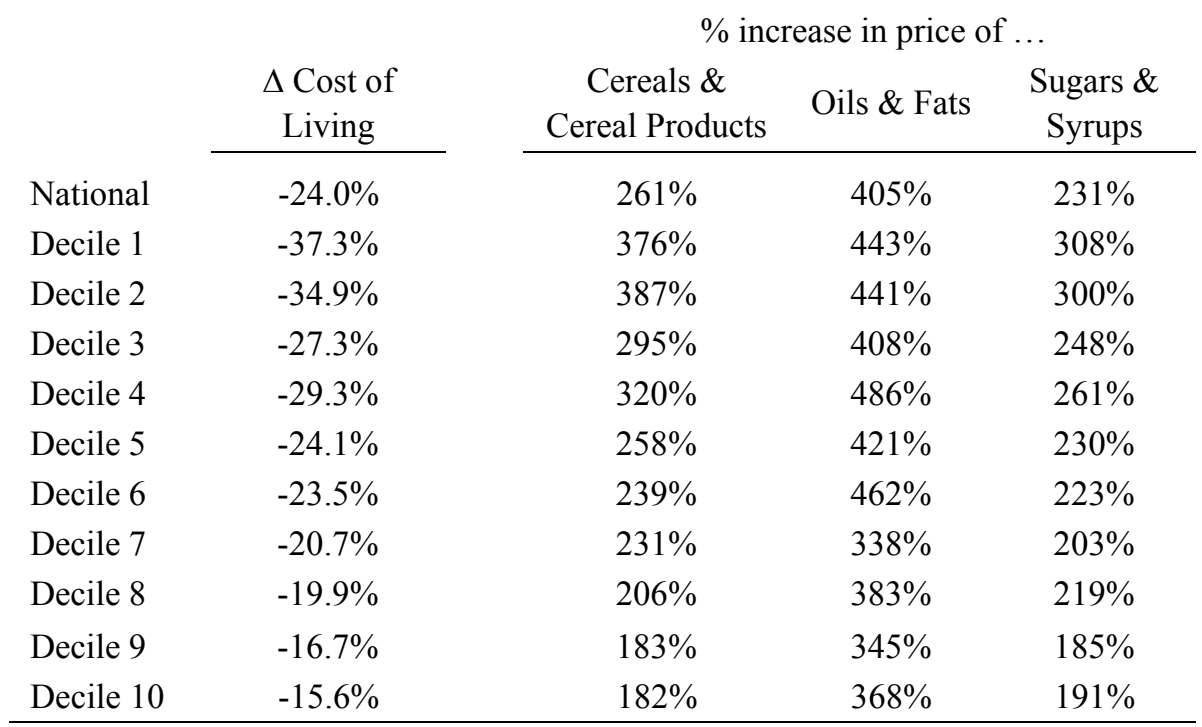

Source: Own estimations using IHSES 2012

It is evident from Table 4 that the price of food groups including PDS commodities would witness extremely high increases following the elimination of PDS subsidies, both from the increase of the price of PDS goods to reach free market levels as well as the expected increase in free market prices of free market equivalents of PDS goods ${ }^{65}$. At the national level, this is expected to lead to a 24 percent reduction in the real value of expenditures. This reduction is as high as 37.3 percent for the poorest decile, falling incrementally to 15.6 percent reduction for the wealthiest decile.

${ }^{65}$ This is 11 percent for commercial wheat flour and 8.5 percent for all other commercial equivalents, based upon findings from a joint WFP-Gol analysis (WFP \& GOI, 2012). 


\section{Compensating Variation}

Welfare effects of eliminating PDS subsidies are estimated through Compensating Variation Ratio (CVR) as defined in Eq. (6). CVR here represents the percent increase in nominal expenditures required to maintain pre-reform utility levels. Overall, eliminating PDS subsidies would lead to a staggering 30.5 percent fall in aggregate welfare. The results indicate that the effects of reform are worse for the poorer deciles, although they remain surprisingly high even among the wealthiest deciles. This is illustrated in Figure 1.

Figure 1: Compensating Variation (\%) by Decile

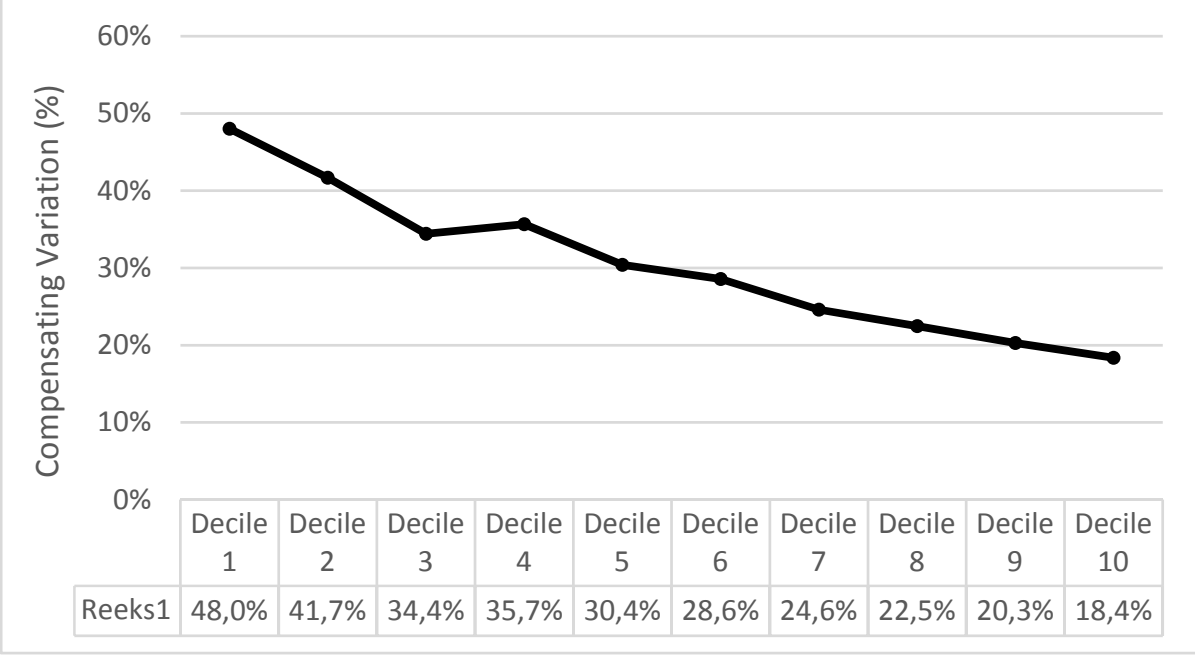

Rolling back PDS subsidies is regressive, where the poorer deciles experience a greater proportional loss of welfare. In nominal terms, however, CVR for the wealthiest is nearly four times higher than that for the poorest decile. In US dollar equivalents, CVR for the wealthiest decile is estimated at $\$ 88.4$ per person monthly compared 
with $\$ 22.9$ per person monthly for the poorest decile. The national aggregate annual CVR is estimated at a shocking US\$16.75 billion ${ }^{66}$.

While shocking in magnitude, this is not all too surprising considering that the annual expenditure on the PDS stood at US\$4.93 billion in December $2012^{67}$. To verify this claim, we consider the additional expense the Iraqi population would have to bear in order to consume an additional US\$4.93 billion worth of food in a year. Given the Iraqi average marginal propensity to consume food from total expenditure, estimated at $0.294^{68}$, it can be estimated that the Iraqi population would need to spend, at least, US\$16.78 billion to consume US\$4.9 billion worth of food in 2012, which is remarkably close to the estimated monetary value of the aggregate $\mathrm{CVR}^{69}$.

${ }^{66}$ All references to US Dollars in this paper assume an average 2012 exchange rate of 1,160 Iraqi Dinar per US Dollar.

${ }^{67}$ According to the Iraq Ministry of Finance consolidated account for December 2012 (http://www.mof.gov.iq)

${ }^{68}$ Considering that Marginal Propensity to Consume $(M P C)$ can be estimated as $M P C=\eta w$ where $\eta$ is the expenditure elasticity, estimated for Iraq at 0.79 , and $w$ is the food budget share, estimated at 37.2 percent.

${ }^{69}$ It is important to note that this does not imply that US\$16.75 would need to be distributed. This only refers to the estimate of the expected aggregate monetary value of welfare loss due to the elimination of PDS subsidies. The US\$16.78 figure is a second estimate of the same, arrived to as the product of the annual value of the food included in PDS rations and the reciprocal of the Marginal Propensity to Consume - thus reflecting the theoretical total private expenditures required to support the private acquisition of US\$4.93 billion worth of food annually. 


\section{Poverty Headcount Ratio}

The microsimulation results indicate that the poverty headcount index is expected to double, rising from the 19.8 percent baseline up to 39.4 percent following the elimination of PDS subsidies. To some extent, this coincides with the results of an earlier World Bank microsimulation performed with data collected in 2007, which reported a simulated poverty headcount ratio of 34.4 due to the uncompensated elimination of PDS subsidies, assuming market prices remain completely unaltered, and up to 40.3 percent if market prices were to double (World Bank \& GOI, 2011). However, the simulation performed in this paper differs somewhat from the one performed by the aforementioned World Bank simulation.

This paper assumes an increase in ration prices to reach market prices, as specified in Eq. (15) and listed in Table 4. The withdrawal of such subsidies and the resultant increased demand on commercial goods is unlikely to pass by without some increase in the prices of the commercially available goods. Accordingly, we account for an additional increase in market prices of free market equivalents equal to 11 percent for wheat flour and 8.5 percent for rice and the remaining food items. This assumption draws on the results of a WFP-GOI longitudinal analysis of Iraqi market price responses to the volume of PDS imports for wheat flour and rice ${ }^{70}$ (WFP \& GOI, 2012).

In addition, while the aforementioned World Bank analysis (World Bank \& GOI, 2011) relies on the Fisher Price Index to estimate overall increase in the cost of living, no effort is made to reflect the potential changes in consumption patterns in response to the price

\footnotetext{
${ }^{70}$ Since the WFP-GOI analysis only included Wheat Flour and Rice, this paper assumes that market prices of the remaining PDS food items would increase at least as much as the expected increase for free market rice, which is 8.5 percent.
} 
shock, thereby biasing the budget shares. In contrast, the present paper applies the transcendental logarithmic price index, defined in Eq. (15), which accounts for both income and substitution effects offering a more realistic picture of the expected change in the cost of living. This is especially important due to the Giffen behavior observed for PDS rice among the poorer deciles reported in Chapter 4. Failure to account for this will lead to underestimation of the increase in cost of living. Finally, the World Bank analysis utilized national average price increases whereas the simulation performed in this paper utilizes the price increases faced by the second and third poorest deciles, which together form the reference group used in the construction of the food poverty line (World Bank, 2014b).

\section{Table 5: Poverty head count index $\left(P_{0}\right)-$ Baseline and Simulated post reform}

National

Loc. Type: Urban

Loc. Type: Rural

HH Size: 1-4 members

HH Size: 5-7 members

HH Size: 8 or more

\begin{tabular}{cc} 
Baseline $(\%)$ & Post reform $(\%)$ \\
\hline 19.8 & 39.4 \\
14.8 & 33.2 \\
30.6 & 52.8 \\
2.8 & 8.2 \\
11.9 & 28.7 \\
29.9 & 54.7 \\
\hline
\end{tabular}

Source: Own estimations using IHSES 2012

Decomposition of the simulated poverty headcount index at the subnational level reveals that poverty is likely to rise more in urban areas than rural areas, with an expected rise of 124 percent in urban locations compared with a 73 percent rise in rural locations. In addition, the effects of eliminating PDS subsidies are greater for smaller households, with an expected 3-fold increase in poverty for households with less than 5 members. 


\subsubsection{Impact of PDS Reform on Food Security}

\section{Nutrient Intake}

The expected change in nutrient intake following the elimination of PDS subsidies, estimated according to Eq. (13) relying on the expected change in real expenditure by decile is presented in Table 6 .

\section{Table 6: Estimated reduction in nutrient consumption nationally and by decile}

\begin{tabular}{lccccccccc} 
& Calories & Protein & Fat & $\begin{array}{c}\text { Carbo- } \\
\text { hydrates }\end{array}$ & Iron & Zinc & Folate & Vit. A & Vit. B12 \\
\cline { 2 - 9 } National & $-15.4 \%$ & $-15.9 \%$ & $-23.2 \%$ & $-12.1 \%$ & $-14.6 \%$ & $-15.6 \%$ & $-20.3 \%$ & $-22.9 \%$ & $-27.2 \%$ \\
Decile 1 & $-14.7 \%$ & $-15.6 \%$ & $-27.2 \%$ & $-10.7 \%$ & $-14.5 \%$ & $-14.1 \%$ & $-28.1 \%$ & $-39.5 \%$ & $-41.4 \%$ \\
Decile 2 & $-16.4 \%$ & $-18.0 \%$ & $-28.3 \%$ & $-12.1 \%$ & $-16.7 \%$ & $-16.8 \%$ & $-27.6 \%$ & $-35.2 \%$ & $-38.4 \%$ \\
Decile 3 & $-14.6 \%$ & $-15.5 \%$ & $-23.9 \%$ & $-11.0 \%$ & $-14.1 \%$ & $-14.9 \%$ & $-22.0 \%$ & $-26.7 \%$ & $-30.5 \%$ \\
Decile 4 & $-16.2 \%$ & $-17.4 \%$ & $-26.5 \%$ & $-12.1 \%$ & $-16.1 \%$ & $-16.7 \%$ & $-24.1 \%$ & $-28.4 \%$ & $-32.8 \%$ \\
Decile 5 & $-14.6 \%$ & $-15.1 \%$ & $-22.8 \%$ & $-11.3 \%$ & $-13.6 \%$ & $-14.6 \%$ & $-20.0 \%$ & $-22.8 \%$ & $-27.1 \%$ \\
Decile 6 & $-15.2 \%$ & $-15.5 \%$ & $-23.0 \%$ & $-11.9 \%$ & $-14.2 \%$ & $-15.0 \%$ & $-19.9 \%$ & $-22.0 \%$ & $-26.3 \%$ \\
Decile 7 & $-14.6 \%$ & $-14.6 \%$ & $-21.2 \%$ & $-11.7 \%$ & $-13.3 \%$ & $-14.7 \%$ & $-17.8 \%$ & $-18.9 \%$ & $-24.0 \%$ \\
Decile 8 & $-14.8 \%$ & $-14.6 \%$ & $-21.0 \%$ & $-12.0 \%$ & $-13.5 \%$ & $-14.6 \%$ & $-17.4 \%$ & $-17.7 \%$ & $-22.8 \%$ \\
Decile 9 & $-13.7 \%$ & $-13.2 \%$ & $-18.3 \%$ & $-11.6 \%$ & $-12.2 \%$ & $-13.3 \%$ & $-14.9 \%$ & $-14.5 \%$ & $-18.8 \%$ \\
Decile 10 & $-14.5 \%$ & $-13.6 \%$ & $-18.2 \%$ & $-12.8 \%$ & $-12.6 \%$ & $-14.0 \%$ & $-14.3 \%$ & $-13.0 \%$ & $-18.2 \%$ \\
\hline
\end{tabular}

Source: Own estimations using IHSES 2012

Overall, the price increases due to eliminating PDS subsidies would reduce macro and micro nutrient consumption across all deciles. For all nutrients, the decrease in nutrient intake is larger for the poorer deciles than the wealthier ones.

Calorie intake is expected to fall by 15.4 percent on average, with much of that expected to be due to reduction in consumption of dietary Fat, which falls by 23.2 percent on average. The largest reduction in consumption is expected for Vitamin B12 as households seek cheaper, plant based nutrients following PDS reform. This highlights the spillover effects of the PDS which - although 
subsidizing consumption of basic staples only - spurs demand for other foods and contributes to a greater diversity of diet across the wealth spectrum. Most concerning is the reduction in consumption of Vitamins A and B12 among the poorest of Iraqi households (39.5\% and $41.4 \%$ respectively) - particularly when previous analysis reports that much of the poorest Iraqis were found to be deprived in these and other essential micronutrients (WFP \& GOI, 2012). Given the importance of micronutrients such as Iron and Vitamin B12 for labor productivity (see for example Ulimwengu et al. (2011)), PDS reform is likely to have greater secondary negative effects on welfare than that captured in the present analysis. Unfortunately, welfare gains often anticipated for rural populations following price liberalization reforms would likely be minimal given the Government of Iraq's already generous agricultural price support policy implemented since 2009 which is set at $15-30 \%$ higher than average international prices for major food crops purchased by the Government, including wheat and rice (Telleria, et al., 2012).

In terms of balance of dietary energy from proteins, fats and carbohydrates, post reform consumption remains within the acceptable boundaries of across all deciles. Following PDS reform, it is expected that the proportion of calories from Proteins will remain at 11.7 percent, nearly equal to baseline levels at 11.8 percent. The proportion of calories from Fat falls by 1.8 percentage points to 22.2 percent on average and this is somewhat compensated by an increase in the share of calories from Carbohydrates up to 59.5 post reform up from 57.8 percent at baseline. The proportion of calories from Protein remains fairly stable across all deciles ranging only between 11.6 and 11.9 percent across deciles. In contrast, the proportion of calories from Fat increases with greater income, rising from 16.5 percent for the poorest decile, rising to 28.7 percent for the wealthiest decile. Conversely, the proportion of calories from Carbohydrates falls from 66.0 to 52.2 percent from the poorest to the wealthiest deciles. The balance of calories from Carbohydrates, Fats and 
Proteins remain within the recommended limits across all wealth groups.

\section{Undernourishment}

Applying the estimated mean calorie consumption by decile $\left(\overline{x_{d}}\right)$ in Eqs. (9) through (12) produces the simulated prevalence of undernourishment in the absence of the PDS as defined in Eq. (8). The method of measuring undernourishment applied in this paper specifies undernourishment as a function of average calorie consumption, inequality in consumption and the minimum dietary requirements. Accordingly, reduced average consumption as well as rising inequality will necessarily lead to a prevalence of undernourishment. The effect of PDS reform on undernourishment is depicted in Figure 2 below.

Figure 2: Probability Density Function of Calorie Consumption pre and post reform

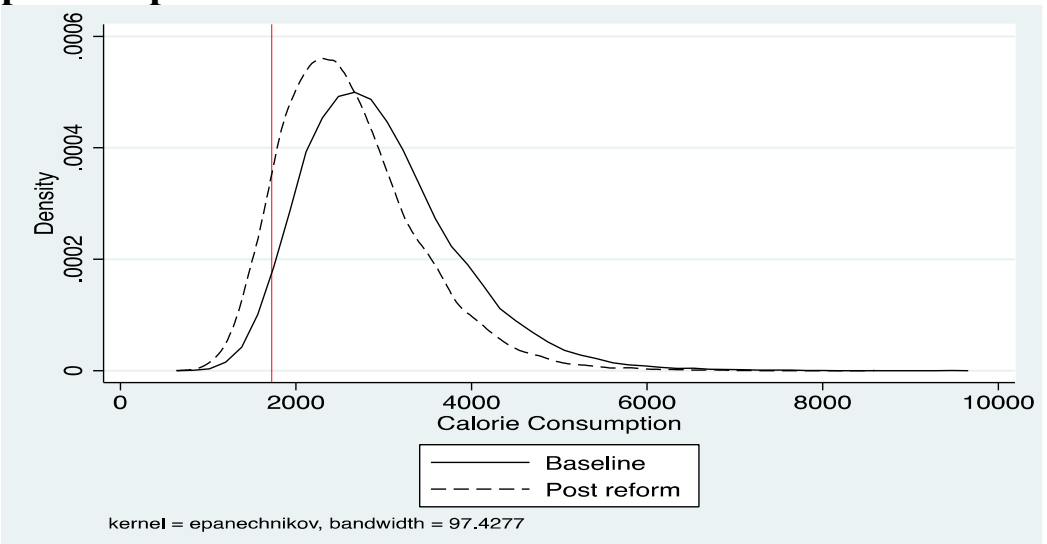

Note: The solid vertical line represents the Minimum Dietary Energy

Requirements (1775 kcal pppd) 
The prevalence of undernourishment estimated in this paper follows a parametric approach. Accordingly, as depicted in Figure 2, the prevalence is estimated as the area under the curve below the Minimum Dietary Energy (MDER) threshold. Accordingly, the prevalence of undernourishment can be understood as the probability that a random individual in the population is undernourished.

\section{Table 7: Undernourishment nationally and sub-nationally - pre and post subsidy reform}

\begin{tabular}{|c|c|c|c|c|c|c|}
\hline & \multicolumn{3}{|c|}{ Baseline } & \multicolumn{3}{|c|}{ Without PDS } \\
\hline & $\begin{array}{c}\text { Mean } \\
\text { Calorie } \\
\text { Consump- } \\
\text { tion } \\
\end{array}$ & $\mathrm{CV}$ & $\begin{array}{l}\text { Under- } \\
\text { nourish- } \\
\text { ment }\end{array}$ & $\begin{array}{c}\text { Mean } \\
\text { Calorie } \\
\text { Consumption }\end{array}$ & $\mathrm{CV}$ & $\begin{array}{l}\text { Under- } \\
\text { nourish- } \\
\text { ment }\end{array}$ \\
\hline National & 3,065 & 0.308 & $4.8 \%$ & 2,607 & 0.311 & $13.3 \%$ \\
\hline Loc. Type: Urban & 3,087 & 0.304 & $4.6 \%$ & 2,626 & 0.308 & $13.2 \%$ \\
\hline $\begin{array}{l}\text { Loc. Type: Rural } \\
\text { HH Size: } 1-4\end{array}$ & 3,017 & 0.315 & $5.1 \%$ & 2,567 & 0.319 & $13.8 \%$ \\
\hline $\begin{array}{l}\text { members } \\
\text { HH Size: 5-7 }\end{array}$ & 3,899 & 0.314 & $1.0 \%$ & 3,318 & 0.318 & $3.6 \%$ \\
\hline members & 3,154 & 0.278 & $2.5 \%$ & 2,685 & 0.281 & $8.7 \%$ \\
\hline HH Size: 8 or more & 2,801 & 0.260 & $4.7 \%$ & 2,383 & 0.263 & $15.2 \%$ \\
\hline
\end{tabular}

Source: Own estimations using IHSES 2012

The results highlighted in Table 7 lists the impacts of eliminating food consumption subsidies on mean calorie consumption and inequality in calorie consumption - two main inputs in the estimation of undernourishment. Overall, undernourishment is simulated to rise from 4.8 percent nationally to 13.32 percent. The largest proportional increase in undernourishment is expected for smaller households with less than 5 members, although this group remains the one with the lowest prevalence.

Following the example of Anríquez et al. (2013), decomposition of the change in undernourishment following PDS reform to change due to growth (negative) in calorie consumption and redistribution is 
performed using $\quad P_{U}^{t 1}-P_{U}^{t 0}=G\left(t^{0}, t^{1} ; r\right)+D\left(t^{0}, t^{1} ; r\right)+$ $R\left(t^{0}, t^{1} ; r\right)$ where $t^{0}$ represents baseline and $t^{1}$ post reform and where $G\left(t^{0}, t^{1} ; r\right)$ reflects the change in mean calorie consumption holding distribution constant and $D\left(t^{0}, t^{1} ; r\right)$ reflects the change in the distribution of calorie consumption (i.e. inequality) holding mean calorie consumption holding constant. The last term, $R\left(t^{0}, t^{1} ; r\right)$, represents the change in undernourishment that is not explained by growth and redistribution independently and can be either positive or negative ${ }^{71}$.

Table 8: Decomposition of change in Undernourishment Due to PDS Reform

National

Loc. Type: Urban

HH Size: 1-4

members

HH Size: 5-7

members

HH Size: 8 or more
Loc. Type: Rural

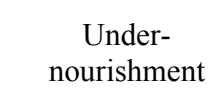

$(\Delta)$

\begin{tabular}{ccccc}
$(\Delta)$ & $\begin{array}{c}\% \\
\text { points }\end{array}$ & $\begin{array}{c}\% \text { of } \\
\text { change }\end{array}$ & $\begin{array}{c}\% \\
\text { points }\end{array}$ & $\begin{array}{c}\% \text { of } \\
\text { change }\end{array}$ \\
\hline $6.4 \%$ & $5.9 \%$ & $90.9 \%$ & $0.4 \%$ & $6.4 \%$
\end{tabular}

Source: Own estimations using IHSES 2012

The majority of the simulated change in the prevalence of undernourishment is due to reduction in mean calorie consumption (90.9 percent) whereas only 6.4 percent of the change is due to increased inequality (redistribution). This is not especially surprising

\footnotetext{
${ }^{71}$ This is estimated but not reported in Table 8 due to space consideration.
} 
despite the regressivity of PDS reform on welfare levels (see Figure 1), particularly since the rate of reduction in expected calories consumption does not vary excessively across deciles (see Table 6). This is because poorer households adjust their consumption patterns to safeguard the availability of calories. In contrast, the effects of PDS reform consumption of micronutrients such as Vitamin B12 is more regressive as poorer households substitute away from the only possible sources of this Vitamin - meat, fish, eggs and dairy towards cheaper sources of dietary energy.

\subsubsection{Nutritional Cost Effectiveness Analysis of Cash and Food Vouchers}

Given the negative effects of eliminating PDS subsidies on welfare and food security, it is unthinkable that the reform process would ever succeed, or even take place to start with, unless effective efforts are exerted to mitigate them. Cash transfer programs have largely become the policy of choice when designing mitigation mechanisms and have increasingly been utilized to replace national food assistance schemes (Devereux, 2009) - a tendency that began to seep into the practices and recommendations of donors and international organizations (Norad, 2011). From Latin America to Africa, the Middle East and Asia, examples abound of food assistance or food subsidy reform processes where cash transfers have been either proposed or already adopted as the mitigating alternative.

This is contrasted with evidence from the United States where a small yet continuous stream of empirical publications from the 1970s up to 2017 have argued that replacing the Supplemental Nutrition Assistance Program ${ }^{72}$ (SNAP), the main food assistance scheme

\footnotetext{
72 Previously known as the Food Stamp Scheme.
} 
managed by the US government, with cash benefits would eventually lead to reduced food consumption among the recipients as analysts have found that the marginal propensity to consume food due to food assistance transfers is higher than that due to cash transfers. Though conflicting with generally accepted economic theory on food subsidy schemes - namely Southworth's theoretical model (Southworth, 1945 ) - the higher marginal propensity to consume food due to food assistance, often referred to as the "cash-out puzzle", has been assessed and confirmed numerous times in a small yet continuous stream of empirical publications from the 1970s through to 2017 (see Chapter 3 for more details). Indeed, this body of literature is arguably the main reason why SNAP remains as a food assistance mechanism and not converted to a cash transfer mechanism.

Yet, what has puzzled empirical analysts concerned with food assistance schemes in the United States does not appear to much burden policy analysts across the developing world, except perhaps organizations with specific food and nutrition security mandates. The increased use of cash in food assistance programmes has led to greater questioning of the choice of transfer modality among international food based humanitarian and development agencies. For example, WFP corporate requirements stipulate the need to undertake nutritional cost effectiveness of different modes of transfer in response to the significant increase in cash and voucher programmes they implement (WFP, 2014).

\section{Omega Value Cost Effectiveness Analysis}

The Omega Value method, which is the nutritional cost effectiveness analysis approach developed within WFP, is a good candidate to be applied in the context of reforming food subsidies in Iraq specifically in suggesting alternative measures to mitigate the impacts of reform on poorer households. 
The Omega value analysis is performed as described in Eqs. (16) and (17). The analysis presents a comparison of the nutritional cost effectiveness of cash transfers and value based food vouchers. While many considerations may enter in the design of a social transfer mechanism, the analysis will only consider the basic parameters of coverage and transfer value. Specifically, the coverage of both the cash and food voucher schemes will be limited to the 39.4 percent of the population estimated to be poor following the elimination of PDS subsidies. The analysis assumes perfect targeting, which is - of course - the unattainable ideal that is practically impossible to achieve $^{73}$. However, given that the purpose of this analysis is to compare the effectiveness of alternative transfer mechanisms, rather than alternative targeting approaches, the simple assumption that both transfer mechanisms would apply the same targeting approach would eliminate any biases due to imperfect targeting from the comparative cost effectiveness analysis ${ }^{74}$.

The transfer values for cash and vouchers, defined using CVR and $C V R_{\text {food }}$ described in Eqs. (5) and (6) respectively are listed in Table 9.

${ }^{73} \mathrm{~A}$ discussion of the targeting errors from one of the more predominant targeting mechanisms - the Proxy Means Test - can be found in Kidd, Gelders, \& BaileyAthias (2017).

${ }^{74}$ There is the possibility that actual targeting performance for the food transfer would be better than for the cash transfer due to self-selection (Coady, Grosh and Hoddinott, 2004). However, accounting for implementation-level differences in targeting is not within the scope of this paper. 
Table 9: Cash and Voucher Transfer Values and Aggregate Costs

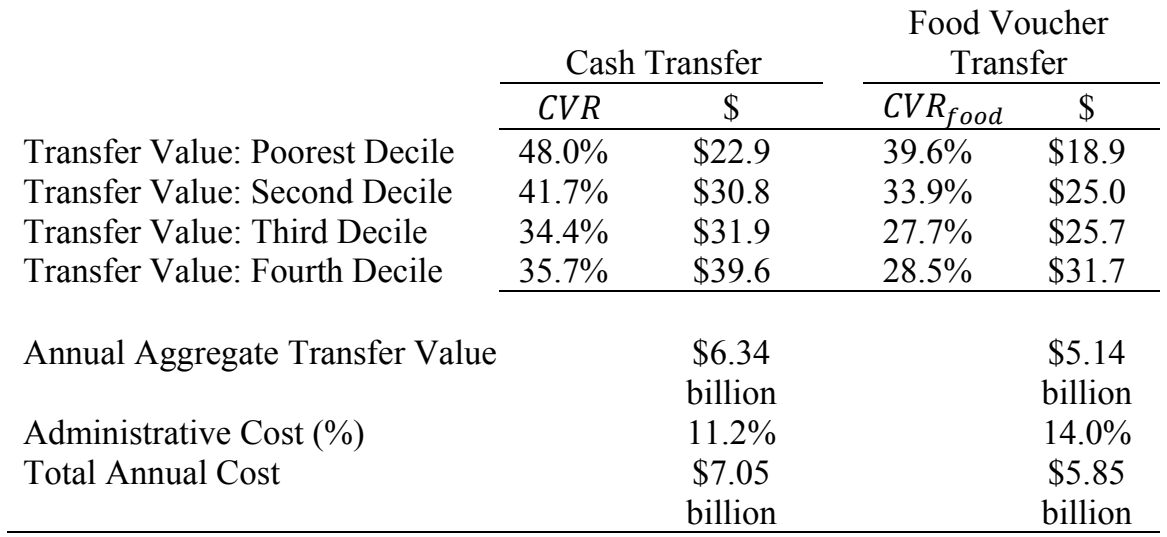

Source: Own estimations using IHSES 2012

The measure of CVR estimated in this paper utilizes the expenditure functions estimated from a complete food demand system and represents the amount of money, expressed as a ratio of current expenditure levels, required to maintain pre-reform utility levels while allowing for the expected alterations in consumption bundles given the expected increase in relative prices. It is therefore a logical choice for the estimation of transfer values.

The use of $C V R_{\text {food }}$ to value the food voucher transfers as opposed to $C V R$ is guided by the results in Chapter 3 which presents evidence suggesting that the food demand elasticity due to a food transfer is approximately equal to one. Applying this to the context of this paper simply implies replacing the cash expenditure elasticities $(\eta)$ in Eq (6) with the elasticity of demand for food from food vouchers, which in stylized form, is taken to equal unity.

Table 9 presents the estimated transfer values for the cash and food voucher schemes, where it is immediately obvious that the transfer values are defined for each decile independently, thus also reflecting the unattainable ideal that requires not only perfect poverty targeting, but also precise allocation of recipients to the proper decile. While practically impossible to achieve, this also does not bear great 
significance in the context of a comparative cost effectiveness analysis as it is reasonable to assume that imperfections in implementation would affect both transfer schemes being compared.

Implementing either scheme comes at a substantial cost. Excluding administrative costs, the aggregate annual cost for the cash transfer is estimated at US\$6.34 billion and for voucher transfers it is estimated at US\$5.14 billion. With administrative costs included, this rises to US\$7.05 billion and US\$5.85 billion for cash and voucher transfers respectively ${ }^{75}$.

Given the defined transfer values for cash and vouchers, undertaking the Omega Value comparative nutritional cost effectiveness analysis begins with the estimation of the Nutrient Value Score (NVS), as described in Eq. (17), for both transfer modalities. This is performed through calculating the difference between the post reform nutrient intake levels and the expected nutrient intake due to each of the transfers.

\footnotetext{
${ }^{75}$ Administrative costs refer to the cost of undertaking the transfer, including initial investments and bank transaction costs but exclude the cost of targeting. As targeting is assumed to be the same under cash or vouchers, including targeting costs would not alter the comparative cost effectiveness analysis. WFP estimated the administrative costs for a cash transfer at 11.2 percent and an electronic food voucher at 14 percent (WFP \& GOI, 2012).
} 
Table 10: Nutrient Value Score (NVS) from Cash and Value Based Vouchers Schemes

\begin{tabular}{|c|c|c|c|c|c|c|c|c|}
\hline & $\begin{array}{l}\text { Calo- } \\
\text { ries } \\
(\mathrm{kc})\end{array}$ & $\begin{array}{l}\text { Prot- } \\
\text { ein } \\
(\mathrm{g})\end{array}$ & $\begin{array}{l}\text { Fat } \\
(\mathrm{g})\end{array}$ & $\begin{array}{l}\text { Iron } \\
(\mathrm{mg})\end{array}$ & $\begin{array}{l}\text { Zinc } \\
(\mathrm{mg})\end{array}$ & $\begin{array}{l}\text { Fol- } \\
\text { ate } \\
(\mathrm{m})\end{array}$ & $\begin{array}{l}\text { Vit. } \\
\text { A } \\
\text { (IU) }\end{array}$ & $\begin{array}{l}\text { Vit. } \\
\text { B12 } \\
(\mathrm{mcg})\end{array}$ \\
\hline $\begin{array}{l}\text { Daily Requirements } \\
\text { Post Reform }\end{array}$ & 2100 & 52.5 & 40 & 12.5 & 5.7 & 257.4 & 1426 & 1.7 \\
\hline $\begin{array}{l}\text { Post Reform } \\
\text { Consumption } \\
\text { Post Transfer }\end{array}$ & 2208 & 65.2 & 47 & 19.2 & 12.0 & 250.2 & 2720 & 1.0 \\
\hline $\begin{array}{l}\text { Post Transfer } \\
\text { Consumption }\end{array}$ & 2550 & 75.4 & 54 & 22.2 & 13.9 & 289.0 & 3141 & 1.2 \\
\hline $\begin{array}{l}\text { Consumption due to } \\
\text { Transfer } \\
\% \text { Of requirements due to }\end{array}$ & 342 & 10.1 & 7 & 3.0 & 1.9 & 38.8 & 421 & 0.2 \\
\hline Transfer & $16 \%$ & $19 \%$ & $18 \%$ & $24 \%$ & $33 \%$ & $15 \%$ & $30 \%$ & $9 \%$ \\
\hline $\begin{array}{l}\text { Nutrient Value Score }= \\
1.64\end{array}$ & 0.16 & 0.19 & 0.18 & 0.24 & 0.33 & 0.15 & 0.30 & 0.09 \\
\hline
\end{tabular}

Source: Own estimations using IHSES 2012

The NVS calculated for both cash and food vouchers is equal to 1.64. It should be noted that the NVS does not hold any intrinsic meaning except in comparing the expected nutrient consumption due to alternative transfer mechanisms. As described in Eq. (17), the NVS is the sum of the proportion of the nutrient specific daily requirements that is attributed to the transfer. Therefore, the NVS is bound to 0 at the lower end, indicating that the transfer does not lead to consumption of any of the nutrients and unbounded at the higher end, except by tastes and preferences of the Iraqi population as estimated by a food demand system.

The transfer schemes are designed such that they produce the same consumption response, thus the estimated NVS due to both schemes are exactly equal. Accordingly, the comparative cost effectiveness analysis narrows down to comparison of costs. The Omega Value $(\Omega)$ can be applied given the information at hand as specified in Eq. (16) where

$$
\Omega=\frac{N V S^{V} / \operatorname{Cost}^{V}}{N V S^{C} /{ }_{\operatorname{Cost}^{C}}}=\frac{1.64 / 5.85}{1.64 / 7.05}=1.21
$$


with the superscripts $C$ and $V$ denote cash and vouchers respectively. Accordingly, the estimated Omega Value of 1.21 implies that the food voucher is 21 percent more nutritionally cost effective than the cash transfer scheme. This can also be achieved by applying Eq. (8) from Chapter 3, which specifies Voucher Cost Effectiveness (VCE) as a function of expenditure elasticity $(\eta)^{76}$ and the administrative cost associated with cash transfers (a) and the administrative cost associated with food vouchers (b). VCE is estimated as

$$
V C E \equiv \frac{1+a}{\eta(1+b)}=\frac{1.112}{0.809(1.14)}=1.21
$$

also confirming that the food voucher scheme is 21 percent more nutritionally cost effective than the cash transfer scheme.

The same results are also reached if the transfer schemes were designed to be bound by the same budget constraints, thus allowing the NVS for the cash transfer scheme to differ from that for the food voucher transfer scheme. In this alternative scenario, both the cash and food voucher transfer are set equal to $C V R_{\text {food }}$, thus the NVS for the food voucher is the same as that estimated above (1.64) and the NVS for the cash transfer is estimated at 1.33 (Table 11).

\section{Table 11: Nutrient Value Score (NVS) from alternative Cash} Transfer Schemes

\begin{tabular}{lcccccccc} 
& $\begin{array}{c}\text { Calorie } \\
(\mathrm{kc})\end{array}$ & $\begin{array}{c}\text { Prot- } \\
\text { ein }(\mathrm{g})\end{array}$ & $\begin{array}{c}\text { Fat } \\
(\mathrm{g})\end{array}$ & $\begin{array}{c}\text { Iron } \\
(\mathrm{mg})\end{array}$ & $\begin{array}{c}\text { Zinc } \\
(\mathrm{mg})\end{array}$ & $\begin{array}{c}\text { Folat } \\
\mathrm{e}(\mathrm{m})\end{array}$ & $\begin{array}{c}\text { Vit. A } \\
(\mathrm{IU})\end{array}$ & $\begin{array}{c}\text { Vit. } \\
\text { B12 } \\
(\mathrm{mcg})\end{array}$ \\
\cline { 2 - 8 } Daily Requirements & 2100 & 52.5 & 40 & 12.5 & 5.7 & 257.4 & 1426 & 1.7 \\
Post Reform Consumption & 2208 & 65.2 & 47 & 19.2 & 12.0 & 250.2 & 2720 & 1.0 \\
Post Transfer Consumption & 2485 & 73.4 & 53 & 21.7 & 13.6 & 281.6 & 3060 & 1.1 \\
$\begin{array}{l}\text { Consumption due to Transfer } \\
\text { \% Of requirements due to }\end{array}$ & 278 & 8.2 & 6 & 2.4 & 1.5 & 31.4 & 340 & 0.1 \\
Transfer & $13 \%$ & $16 \%$ & $15 \%$ & $19 \%$ & $27 \%$ & $12 \%$ & $24 \%$ & $7 \%$ \\
Nutrient Value Score $=\mathbf{1 . 3 3}$ & 0.13 & 0.16 & 0.15 & 0.19 & 0.27 & 0.12 & 0.24 & 0.07 \\
\hline
\end{tabular}

Source: Own estimations using IHSES 2012

${ }^{76}$ The elasticity of 0.809 presented here is the weighted average of the elasticities for the poorest 4 deciles. 
Repeating the Omega Value analysis with the new parameters indicates, once again, that the food voucher scheme would be 21 percent more nutritionally cost effective than the cash transfer scheme.

\subsubsection{Simulated Impact of Cash and Food Vouchers}

The impact of both cash and food voucher schemes on poverty and undernourishment is assessed, applying the same general approach for the poverty simulation as that applied previously in Section 4.1. For undernourishment, this is performed by estimating the increase in calorie consumption due to the transfer and estimating average calorie consumption by decile of the rearranged rank order of the population following the transfer. Plugging the decile average calorie consumption in Eqs. (9) through (12) produces the post-transfer average dietary energy consumption $\left(\mu_{x}\right)$ and coefficient of variation of dietary energy consumption $\left(V_{x}\right)$ which are finally applied as described in Eq. (8) to simulate the prevalence of undernourishment.

The results of the simulation are listed in Table 12 including baseline, post reform and post each of the considered transfer schemes. 
Table 12: Calorie consumption and undernourishment pre and post subsidy reform and transfers

\begin{tabular}{|c|c|c|c|c|}
\hline & $\begin{array}{c}\text { Pre } \\
\text { Reform }\end{array}$ & & ost Refo & \\
\hline & Baseline & $\begin{array}{l}\text { Uncomp- } \\
\text { ensated }\end{array}$ & $\begin{array}{c}\text { Cash } \\
\text { Transfer }\end{array}$ & $\begin{array}{l}\text { Voucher } \\
\text { Transfer }\end{array}$ \\
\hline Decile 1 & 2,198 & 1,876 & 2,175 & 2,175 \\
\hline Decile 2 & 2,493 & 2,084 & 2,433 & 2,430 \\
\hline Decile 3 & 2,671 & 2,282 & 2,542 & 2,583 \\
\hline Decile 4 & 2,800 & 2,346 & 2,632 & 2,597 \\
\hline Decile 5 & 3,005 & 2,565 & 2,691 & 2,710 \\
\hline Decile 6 & 3,168 & 2,686 & 2,706 & 2,678 \\
\hline Decile 7 & 3,386 & 2,890 & 2,890 & 2,890 \\
\hline Decile 8 & 3,720 & 3,168 & 3,168 & 3,168 \\
\hline Decile 9 & 3,988 & 3,441 & 3,441 & 3,441 \\
\hline Decile 10 & 5,122 & 4,379 & 4,379 & 4,379 \\
\hline National & 3,065 & 2,607 & 2,772 & 2,772 \\
\hline $\begin{array}{l}\text { Coefficient of } \\
\text { Variation }\end{array}$ & 0.308 & 0.311 & 0.271 & 0.273 \\
\hline $\begin{array}{l}\text { Undernourishment } \\
(\%)\end{array}$ & 4.78 & 13.32 & 6.17 & 6.16 \\
\hline
\end{tabular}

Source: Own estimations using IHSES 2012

The cash transfer scheme delivering a transfer value equal to $C V R$, and the food voucher scheme delivering a transfer value equal to $C V R_{\text {food }}$ contribute significantly to reversing the rise in the prevalence of undernourishment due to the elimination of PDS subsidies. However, the post transfer prevalence remains higher than the baseline. The prevalence of undernourishment, which is estimated at 4.78 percent at the pre reform baseline and simulated to rise to 13.32 percent as a result of eliminating PDS subsidies, is simulated to fall back down to approximately 6.2 percent as a result of either transfer scheme. The slight difference between the cash transfer and food voucher transfer $(6.17 \%$ and $6.16 \%$ respectively) is attributed to the differences in the rearrangement of the rank order of 
the population owing to the fact that the cash transfer is nominally more generous.

The reduction in undernourishment is achieved through an increase in mean calorie consumption coupled with a reduction in inequality in calorie consumption. The decomposition of change in undernourishment shows that 53.8 percent of the expected reduction in undernourishment is attributed to growth in consumption alone while 53.6 percent can be attributed to redistribution alone.

\section{Table 13: National and Subnational Undernourishment pre and post subsidy reform and transfers}

\begin{tabular}{|c|c|c|c|c|}
\hline & \multirow{2}{*}{$\begin{array}{c}\text { Pre } \\
\text { Reform } \\
\text { Baseline }\end{array}$} & \multicolumn{3}{|c|}{ Post Reform } \\
\hline & & $\begin{array}{l}\text { Uncomp- } \\
\text { ensated }\end{array}$ & $\begin{array}{c}\text { Cash } \\
\text { Transfer }\end{array}$ & $\begin{array}{l}\text { Voucher } \\
\text { Transfer }\end{array}$ \\
\hline National & 4.78 & 13.32 & 6.17 & 6.16 \\
\hline Loc. Type: Urban & 4.64 & 13.15 & 5.98 & 5.97 \\
\hline Loc. Type: Rural & 5.13 & 13.75 & 6.93 & 6.89 \\
\hline HH Size: 1-4 members & 0.95 & 3.63 & 1.20 & 1.18 \\
\hline HH Size: 5-7 members & 2.45 & 8.74 & 3.73 & 3.73 \\
\hline HH Size: 8 or more & 4.69 & 15.19 & 7.59 & 7.57 \\
\hline
\end{tabular}

Source: Own estimations using IHSES 2012

Subnational prevalence of undernourishment is also simulated to fall significantly, though undernourishment is simulated to remain higher for all considered subnational groups than the baseline prevalence. Simulations show that rural households are affected more than urban households, with the latter facing a 34 percent increase in the prevalence and the former facing 29 percent increase in the prevalence. Also, larger households are simulated to experience greater proportional increases in undernourishment compared with smaller households. 
It is sufficiently apparent that the designed transfer mechanisms, despite being perfectly targeted and with transfer values exactly equal to decile-specific compensating variation, fails to fully reverse the negative effects of eliminating PDS subsidies on the prevalence of undernourishment.

Simulating the effects of the cash transfer scheme on the poverty headcount ratio, however, paints a slightly different picture.

\section{Table 14: National and Subnational Poverty pre and post subsidy reform and transfers}

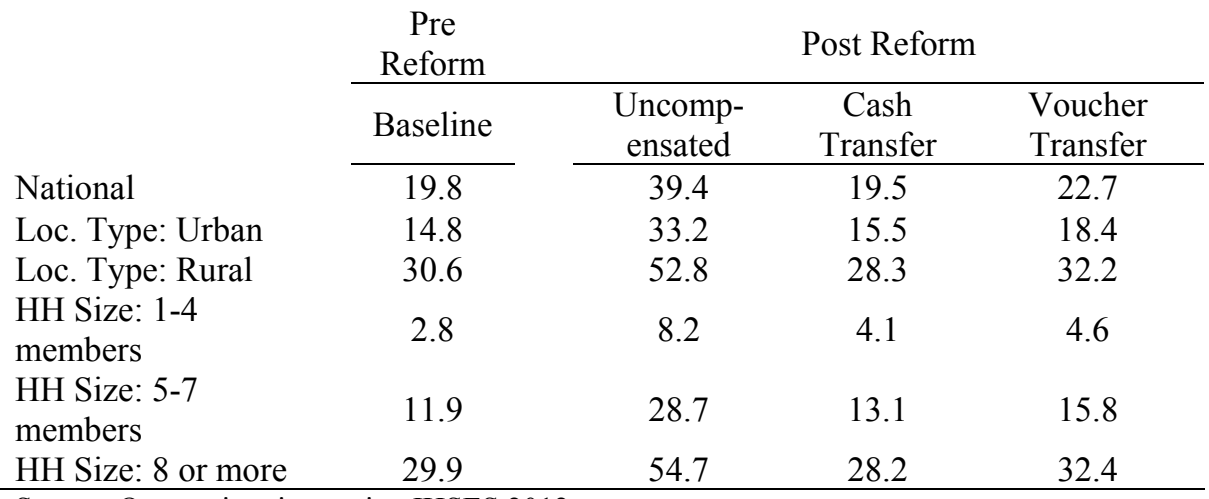

Source: Own estimations using IHSES 2012

The poverty headcount index for Iraq, which is estimated at 19.8 percent at the pre reform baseline and simulated to rise to 39.4 percent as a result of eliminating PDS subsidies, is simulated to return to 19.5 percent after accounting for the cash transfer. At the subnational level, the simulated poverty rate after the cash transfer is also very close to the baseline, though urban poverty is found to be slightly higher (15.5 percent compared to 14.8 percent at the baseline) and rural poverty slightly lower than the baseline (28.3 percent compared to 30.6 percent at the baseline). Small differences are also observed for household size, where smaller households appear slightly worse off following the reform and mitigation efforts 
compared with the baseline, while larger households are slightly better off following the cash transfer than at the baseline.

The simulated poverty headcount following the food voucher, however, remains higher than the baseline poverty rate. This is attributable to the fact that the nominal value of the food voucher is lower than the nominal value of cash transfer. The aggregate cash transfer value is approximately 23 percent higher than the aggregate voucher transfer value (See Table 9).

Whereas estimating the food consumption value of the food voucher is bound by the fact that the elasticity of food demand from food vouchers is higher than the elasticity of food demand from cash, thereby producing similar food consumption impacts, this cannot be reflected in the poverty simulation unless the food vouchers are valued at higher than its nominal value. The findings of Chapter 3, particularly the suggestion that the elasticity of food demand from food vouchers is approximately equal to one, implies that the nominal value of the food voucher can be logically adjusted to reflect the higher marginal utility of food vouchers relative to cash transfers, in which case both cash transfer and food voucher could possibly generate the similar impacts. However, this is not pursued in the present paper as it is sufficient to note that the perfectly targeted cash transfer, valued using the estimated measure of Compensating Variation, is simulated to near perfectly reverse the welfare loss to the poor following the elimination of PDS subsidies.

\subsection{Discussion}

The results presented in the preceding Section, both regarding the nutritional cost effectiveness analysis of cash and food vouchers and regarding the simulation of their impacts on poverty and 
undernourishment, raise several pertinent questions that merit further consideration.

\section{Cost Effectiveness Analysis}

The cost effectiveness analysis performed in this paper represents an extension of the Omega Value methodology enabling an ex ante comparative nutritional cost effectiveness analysis of food vouchers relative to cash transfers. Building upon the evidence surrounding the cash-out puzzle in Chapter 3, the approach presented here illustrates the ease of undertaking an ex ante cost effectiveness analysis using only a few parameters - namely expenditure elasticity of demand for food and basic information on administrative costs of implementing cash and food vouchers.

Yet, such a formulaic expression of nutritional cost effectiveness raises the question of whether cash transfers could ever exceed food vouchers as the more nutritionally cost effective option. The results presented in this paper, as well as in Chapter 3, in fact do not preclude such a possibility, which can occur under two conditions. First, it is apparent that targeting the assistance to the poorest increases the relative cost effectiveness of cash. Expenditure elasticity of demand for food rises with greater poverty, therefore it is plausible that a very narrowly targeted cash transfer can be at least as cost effective as a food voucher. If demand for food is greater than unit elastic, then cash would be the more nutritionally cost effective option. While this is admittedly rare to observe it should be pointed out that the analysis performed in this paper relies upon elasticities estimated at decile means, whereas estimating point elasticities may reveal a proportion of the population with sufficiently high expenditure elasticities, presumably among the very poorest of Iraqi society, to render a cash transfer nutritionally more cost effective than a food voucher. 
The second condition would be if the administrative costs of administering food vouchers are significantly higher than the cost of implementing a cash transfer. For cash transfers to be more cost effective than food vouchers as a result of administrative costs alone, the food voucher administrative costs $(b)$ would need to be high enough such that $(1+b)>(1+a) \eta^{-1}$. In the case of Iraq, particularly the poorest 39.4 percent of the population intended to receive the transfer, this would require administrative costs for the food voucher to be higher than 37 percent of the aggregate voucher transfer value - which is unrealistically high particularly in relation to the 11.2 percent administrative costs of a cash transfer assumed for Iraq.

Barring an inordinately high administrative cost for food vouchers relative to those for cash transfers, the main influence in the cost effectiveness analysis of food vouchers relative to cash transfers is the expenditure elasticity of demand for food. With some international evidence indicating that expenditure elasticity of demand for food range between 0.854 and 0.346 (Muhammad, Seale, Meade, \& Regmi, 2011), it is evident that cash transfers cannot simply be assumed to be the most effective approach in improving food and nutrient consumption unless verified through comparative cost effectiveness analysis such as that performed in this paper.

\section{Differences in Poverty and Food Insecurity Impacts}

Additional consideration is also warranted for the results of the simulations presented in this paper. Comparing the simulated impacts of the cash transfer scheme on poverty reported in this paper with the impacts reported by the World Bank for Iraq shows significant disparities that should be explained. The analysis reported in the present paper shows that the rise in poverty due to eliminating PDS subsidies can be reversed with a budget determined by the 
estimated value of the aggregate Compensating Variation for the poorest 4 deciles, which in 2012 dollar terms amounts to US\$6.34 billion. Though the restrictive assumptions of perfect targeting and perfect allocation of transfer values relegates this option to an unattainable ideal. In contrast, World Bank simulations estimate that - under similar targeting assumptions - a far less generous cash transfer scheme would nearly eradicate poverty in Iraq, reducing post PDS elimination poverty rates from 34.4 percent down to 4.5 percent if market prices were to remain stable, or from 40.3 percent down to 18.1 percent if market prices of food were to double (World Bank \& GOI, 2011).

This discrepancy, however, is fully explained by differences in methodological choices and assumptions. Recalling the poverty microsimulation approach described in Section 3 of this paper, the main adjustment applied to the survey data to perform the simulation is to account for the increased cost of living following the removal of PDS subsidies. In the present paper, baseline consumption expenditures are deflated with expected rate of increase in the cost of living facing the second and third poorest deciles, which together constitute the reference group used in defining the poverty line for Iraq. The approach followed by the World Bank in Iraq, however, deflates baseline consumption expenditures with the expected national average rate of increase in the cost of living (World Bank \& GOI, 2011).

Given that the poor are disproportionately affected by eliminating subsidies, using average expected increases in the cost of living produces both a lower estimated impact of eliminating subsidies as well as greater estimated impact of the cash transfers. This practice is also observed in other contexts as well, such as in Libya (Araar, Choueiri, \& Verme, 2015) and in broader global perspective papers (see for example, De Hoyos \& Medvedev (2009). It should be noted, however, that this practice is not universally applied within the World 
Bank, as other World Bank publications apply inflation rates observed by the poor, such as the "poor person's price index" for Latin American and Caribbean countries (World Bank, 2008). This practice as also not unique to the World Bank, as also the WFP simulation of the impact of reforming the Iraqi PDS (WFP \& GOI, 2012) applied a single average rate of inflation, which unsurprisingly had the same effect of underestimating the impacts relative to the results presented in this paper.

Another aspect of the simulations reported in this paper warranting further consideration is the fact that both mitigation measures fail to fully reverse the simulated increase in undernourishment, while at least the cash transfer is simulated to effectively reverse the expected increase in poverty.

First, it should be acknowledged that the measure of compensating variation applied in this paper allows the compensated to maintain pre-reform utility levels, but not necessarily with the same pre-reform consumption bundle. It is perfectly reasonable that in the prevailing market conditions following the elimination of PDS subsidies, utility can be maintained constant while observing less calorie consumption as the increase in the relative price of food induces a shift in consumption of non-food goods. Yet, this does not necessarily explain the full extent of the issue, particularly since both the poverty simulation and undernourishment simulation account for behavioral responses in a similar fashion.

The other possibility lies in the differences in the methods of measuring poverty and undernourishment - not only in the practical details of the methods, but also in the very axioms underpinning the concepts of poverty and food insecurity. For poverty measurement, the focus axiom is of particular relevance to the current problem.

The focus axiom addresses the importance of maintaining the poverty measure as a characteristic of only the poor within the society rather 
the general poverty of the society as a whole. Thereby, the focus axiom isolates the income of the poor from the rest of society in such a way that prevents an increase in the income of the non-poor to outweigh a fall in the income of the poor (Sen, 1981). In practice, this is achieved in the Poverty Headcount Index reported in this paper through censoring the consumption expenditure vector at the poverty line. While the Poverty Headcount Index answers the question of 'how much poverty there is' in the society, other poverty measures that reject the focus axiom - such as Anand's (1977) modification of the Sen Index or Subramanian's externality-adjusted measure of poverty (2009) - answer the question 'how poor is the society' (Subramanian, 2012).

As such, the poverty headcount index determines that, following the poverty targeted compensation, the number of poor in Iraq would not increase following the elimination of PDS subsidies. Although, this is achieved through fully ignoring the significant loss of welfare experienced by the remaining population, which from Figure 1 can be seen to be anywhere between 30 and 18 percent of pre-reform expenditure levels.

In contrast, the method to estimate the prevalence of undernourishment applied in this paper does not necessarily 'measure' as much as it 'estimates' undernourishment in probabilistic terms - specifically as the probability of observing consumption within the population that falls below the minimum calorie consumption threshold (Cafiero, 2014). The probabilistic framework for the method of undernourishment therefore precludes an actual 'identification' of the undernourished. It follows, therefore, that the method of estimating the prevalence of undernourishment rejects the focus axiom, and thus strives to answer the question 'how food insecure is the society' rather than 'how many food insecure individuals are there' in the society. This is achieved by considering the distribution of consumption across the entire society and does not 
disregard consumption levels at the higher end of the distribution, particularly its implications on average consumption and the overall inequality in consumption.

This does not, however, imply that the undernourishment method applied here is necessarily a poor measure of food security. Though, admittedly, the literature on the axiomatic underpinnings of food security measurement is decidedly underdeveloped, there appears no prerogative why a food security measure should satisfy the focus axiom. Indeed, it is arguable that the "stability" pillar of food security, introduced in Section 2 of this paper, precludes the need to satisfy a focus axiom. Recalling the definition of food security as a condition that exists when "all people, at all times, have physical, social and economic access to sufficient, safe and nutritious food", the stipulation of "at all times" implies that heightened risk to food security is itself a manifestation of food insecurity. This is confirmed by the single publication attempting to define food security measurement axioms (Upton, Cissé, \& Barrett, 2016), which relies on the four pillars of food security, and which translates "at all times" stipulation into the "time axiom" of food security measurement encompassing "predictable and unpredictable variability over time".

This discrepancy between poverty and undernourishment has gained recent attention in the literature, with some studies asserting that economic growth is a helpful but insufficient factor in reducing child malnutrition or micronutrient malnutrition (Ecker, Breisinger, \& Pauw, 2012), and that the great majority of underweight women and undernourished children in sub-Saharan Africa are actually not found in the poorest 20 percent of households (Brown, Ravallion, \& van de Walle, 2017).

It is therefore plausible that the elimination of PDS subsidies and the compensation of the poor with a cash transfer or a food voucher transfer can leave Iraq no poorer yet generally more food insecure. This echoes the argument put forth in the Chapter 1, which presents 
evidence of heightened food insecurity following the replacement of universal consumption subsidies with cash transfers in a variety of contexts ranging from Mexico to Nigeria to Sri Lanka to Iran.

Finally, the analysis presented in this paper leads to the inescapable question of whether eliminating the PDS is a reasonable policy at all. Indeed, the results presented in this paper raise questions about the efficiency of replacing universal subsidy schemes with targeted cash or food voucher transfer schemes. The aggregate monetary measure of welfare loss to Iraqi society as a whole due to the elimination of the PDS subsidy - estimated at US\$16.75 billion in $2012^{77}$ - is far larger than the cost of maintaining the subsidy, which cost US\$4.9 billion in the same year. In addition, replacing a US\$4.93 billion universal food subsidy with a US\$6.34 billion poverty targeted cash transfer scheme or even a US\$5.14 billion poverty targeted food voucher transfer is unlikely to garner sufficient political support to be implemented.

\subsection{Conclusion}

This paper applies an approach to account for the effects of food subsidy reform on welfare and food security. With the resurgence of violence in Iraq following the loss of nearly one third of the territory of Iraq to the Islamic State terrorist organization in 2014, little progress has been achieved in reforming the Public Distribution System (PDS). However, as Iraq continues to regain sovereignty in the areas lost to the Islamic State and struggles to regain normalcy after decades of suffering from war, sanctions and terrorism,

\footnotetext{
77 This is the estimated aggregate annual Compensating Variation due to the elimination of PDS subsidies.
} 
discussions over the future of the PDS have resurfaced. The Iraqi Parliament has discussed a first draft of a law that would transform the PDS system into an electronic benefit transfer mechanism, though which maintains the flexibility in the system to enable any possible form of alteration to the system, including transferring it to either a value based food voucher redeemable in the Iraqi market place or a cash transfer mechanism.

In this paper, the food demand system parameters and the resulting food and nutrient demand elasticities estimated in Chapter 4 are applied in simulating the welfare and food security impacts of eliminating PDS and replacing it with a targeted cash or food voucher transfer mechanism.

The application of ex ante policy analysis methods to the Iraq context provides valuable insight into the effects of eliminating PDS food subsidies on welfare and food security. The analysis reveals that price increases following the removal of PDS subsidies would lead to a 24 percent rise in the cost of living resulting in a 30.5 percent fall in welfare relative to average pre-reform welfare levels as measured by Compensating Variation (CV). The effects of PDS reform on welfare are felt more intensely by the poorer segments of Iraqi society as the poorest decile is expected to experience a 48 percent loss of welfare relative to pre reform welfare levels for this decile. This ratio falls to 18.4 percent for members of the wealthiest decile. The national aggregate monetary value of the $\mathrm{CV}$ is estimated at US $\$ 16.75$ billion, compared to the actual cost of the PDS to Government in Iraq of US $\$ 4.93$ billion. This is further confirmed by the estimated total private consumption expenditure equivalent of US $\$ 4.93$ billion worth of food consumption, which is also estimated at US $\$ 16.78$ billion, and is estimated using the observed average Marginal Propensity to Consume for Iraq.

Using nutrient demand elasticities estimated in Chapter 4, the effects of eliminating PDS subsidies on nutrient consumption are simulated. 
Average calorie consumption is simulated to fall from 3,065 to 2,607 kilocalories per person daily. Proportionally, poorest decile experience a 14.7 percent fall in calorie consumption due to PDS reform while this proportion does not vary much between poorer and wealthiest segments of Iraqi society. Consumption of fats falls by 23.2 percent nationally, which accounts for most of the reduction in calorie consumption. This is expected considering that Vegetable oil was the most subsidized good of all goods included in the PDS food basket.

The effect of eliminating PDS subsidies on nutrient consumption is most pronounced for micronutrients among members of the poorest deciles. Essentially, the consumption response of the poorest members of Iraqi society in response to PDS reform can be characterized by a large shift in consumption away from the relatively more expensive micronutrient rich foods towards the relatively cheaper calorie rich foods. In contrast, wealthier Iraqis are expected to reduce consumption of all nutrients fairly equally across the board.

Iraq has made significant progress in reducing the prevalence of undernourishment in the past decade. The prevalence of undernourishment stood at 7.1 percent in 2007, falling down to 5.7 percent in 2011 and to 4.8 percent in 2012. Simulations presented in this paper indicate that eliminating the PDS threatens to reverse this trend as the prevalence of undernourishment would rise up to 13.3 percent if the reform process is unaccompanied by any mitigation measures. Similarly, poverty is simulated to rise from 19.8 percent to 39.4 percent nationally following the elimination of PDS subsidies.

Ex ante simulation is applied to assess the comparative cost effectiveness of a cash transfer scheme and a food voucher scheme designed to mitigate the worse effects of PDS reform. This is performing using the Omega Value approach to nutritional cost effectiveness analysis, which was developed by the World Food Programme to support decision making on optimal transfer 
mechanisms. The Omega Value compares the nutritional value per dollar investment in two alternative transfer mechanisms - cash and food vouchers - to identify the transfer mechanism that delivers the greatest nutritional benefit to the intended recipients. Although originally designed to compare two alternative food baskets for the design of an in-kind food transfer, this paper demonstrates the applicability of the approach to comparative cost effectiveness analysis of cash and food voucher transfers as well. This paper also demonstrates the applicability of the conclusions reached in Chapter 3 regarding the greater elasticity of demand for food from food vouchers - what is broadly known and the "cash-out puzzle" - to directly estimate the Omega Value comparing food vouchers to cash transfers.

Accordingly, the contribution of this paper to the food security policy analysis literature is the presentation of a novel approach to undertake ex ante cost effectiveness analysis of cash and food vouchers. The paper utilizes food and nutrient demand elasticities as well as empirical evidence of a higher elasticity of demand for food due to food assistance than due to cash in order to expand the application of the Omega Value cost effectiveness analysis metric to cash and value based food vouchers. The nutritional cost effectiveness analysis confirms that food vouchers are 21 percent more cost effective than cash transfers in improving consumption of both macro and micro nutrients.

The paper examines the effects of a cash transfer and food voucher transfer, targeted to the 39.4 percent of the population estimated to be poor following the elimination of PDS, through simulating the post reform, post transfer prevalence of undernourishment and poverty. The results of the simulations indicate that a poverty targeted food voucher or a cash transfer equal to the amount suggested by the Compensating Variation reduces post PDS reform undernourishment from 13.3 to 6.2 percent. While this reversal is significant, it is not 
complete and is also very costly. The aggregate annual value of the cash transfer is estimated at US\$6.34 billion and of the food voucher is estimated at US\$5.14 billion in 2012 dollar terms, both of which are higher than the actual expenditure on the PDS incurred by the Government in 2012. However, the defined cash transfer scheme is simulated to completely reverse the rise in the national poverty rate, returning the national prevalence from the high of 39.4 percent following the elimination of subsidies down to 19.5 percent, which is practically identical to the pre-reform prevalence.

It should be noted, however, that the analysis presented in this paper reflects a partial and incomplete picture of the full extent of the potential impacts throughout the economy as a whole. Macro level general equilibrium models with links to microsimulation models of the household sector are more adept at capturing the full extent of potential impacts. This area of study is underserved in the developing world and is worthy of further research, not only in models that capture the effects of decreasing market distortions but also in capturing the effects of reduced micronutrient intake on labour productivity and wage growth.

Limitations notwithstanding, the results reported in this paper raise questions on the efficiency of replacing universal subsidy schemes with targeted cash or food voucher transfer schemes. This paper suggests that, on aggregate, the monetary measure of welfare loss due to eliminating such consumption subsidies can be far larger than the cost of maintaining them.

The overall picture painted by the analysis of the effects of replacing the universal food consumption subsidy with a targeted cash or food voucher transfer is that the investment required to undertake a poverty-neutral reform process is both costlier than the subsidy itself as well as insufficient to prevent a rise in undernourishment. 
This paper also contributes to advance the understanding of the differential impacts of food subsidy reform on welfare and food security. This paper finds that typical compensation measures that can fully mitigate the effects of food subsidy reform on the prevalence of poverty, can fail to fully mitigate the effects of food subsidy reform on the prevalence of undernourishment. This is explained not only by the methodological differences in measuring poverty and undernourishment, but also by differences in the axioms underpinning the measurement methods.

The tendency of monetary measures of poverty to assess the positive effects of compensating the poorest, effectively ignoring the welfare loss experienced by the rest of society has no parallel in the measurement of undernourishment. The method of measuring undernourishment applied in this paper, which is the globally adopted Sustainable Development Goal indicator, reflects the positive effects of compensating the poorest though is also sensitive to consumption across the full distribution and to inequality in consumption. This paper demonstrates a discrepancy between poverty and food insecurity whereby the elimination of PDS subsidies and the compensation of the poor with a cash transfer or a food voucher transfer can result in an Iraq that is no less poor, though generally more food insecure. 


\subsection{Bibliography}

Ackah, C., \& Appleton, S. (2007). Food price changes and consumer welfare in Ghana in the 1990's. CREDIT Research Paper.

University of Nottingham. No.07/03.

Anand, S. (1977). Aspects of Poverty in Malaysia. Review of Income and Wealth, 23(1), 1-16.

Anríquez, G., Daidone, S., \& Mane, E. (2013). Rising Food Prices and Undernourishment: A Cross-Country Inquiry. Food Policy, 38, 190-202.

Araar, A., Choueiri, N., \& Verme, P. (2015). The quest for subsidy reforms in Libya. Policy Research Working Paper No.7225. Washington, DC: World Bank Group.

Banks, J., Blundell, R., \& Lewbel, A. (1997). Quadratic Engel Curves and Consumer Demand. The Review of Economics and Statistics, 79(4), 527-539.

Beatty, T. K., \& Tuttle, C. J. (2014, November). Expenditure Response to Increase in In-Kind Transfer: Evidence From the Supplemental Nutrition Assistance Program. American Journal of Agricultural Econonomics, 97(2), 390-404.

Botchwey, K., Collier, P., Gunning, J., \& Hamada, K. (1998). External Evaluation of the ESAF: Report by a Group of Independent Experts. Washington, DC: International Monetary Fund.

Bourguignon, F., \& Pereira da Silva, L. A. (2003). The Impact of Economic Policies on Poverty and Income Distribution: Evaluation Techniques and Tools. Washington, DC.: The World Bank and Oxford University Press.

Bourguignon, F., Pereira da Silva, L., \& Stern, N. (2006). Evaluating the poverty impact on economic policies: some analytical challenges. In A. a. Mody, Macroeconomics Policies and Poverty Reduction (pp. 36-70). London, UK: Routledge.

Brown, C., Ravallion, M., \& van de Walle, D. (2017). Are Poor Individuals Mainly Found in Poor Households? Evidence Using Nutrition Data for Africa. Working Paper 24047. National Bureau of Economic Research. 
Cafiero, C. (2014). Advances in Hunger Measurement: Traditional FAO Methods and Recent Innovations. FAO Statistics

Division Working Paper Series, ESS/14-04. Rome: The Food and Agriculture Organzation (FAO).

Capéau, B., Decoster, A., \& Phillips, D. (2014). Consumption and Indirect Tax Models. In C. O’Donoghue (ed.), Handbook of Microsimulation Modelling (pp. 223 - 273). Emerald Group Publishing Limited.

Christiaensen, L., Demery, L., \& Paternostro, S. (2002). Growth, Distribution and Poverty in Africa: Messages from the 1990s. Poverty Dynamics in Africa . Washington, DC: World Bank.

Coady, D., M. Grosh and J. Hoddinot. (2004). Targeting of Transfers in Developing Countries: Review of Lessons and Experience. Washington, DC: World Bank.

Committee on World Food Security. (2012). Coming to Terms with Terminology. Rome: Committee on World Food Security (CFS) 39th Session.

Cornielje, O. (1985). Calibration in Applied General Equilibrium Modelling: The Case of Rationed Households. Economics Letters, 19, 211-215.

De Hoyos, R., \& Medvedev, D. (2009). Poverty Effects of Higher Food Prices: A Global Perspective. Washington, DC: The World Bank.

Devereux, S. (2009). Social Protection for Agricultural Growth in Africa. Growth and Social Protection Working Paper No. 6. Brighton: Future Agricultures Consortium.

Devereux, S. (2016). Social protection for enhanced food security in sub-Saharan Africa. Food Policy, 60, 52-62.

Ecker, O., Breisinger, C., \& Pauw, K. (2012). Growth is good, but is not enough to improve nutrition. In S. Fan, \& R. PandyaLorch (Eds.), Reshaping Agriculture for Nutrition and Health (pp. 47-54). International Food Policy Research Institute.

FAO \& IAU. (2009). Iraq Food Prices Analysis. Baghdad, Iraq: The Inter Agency Information and Analysis Unit (IAU).

Foster, J., Greer, J., \& Thorbecke, E. (1984). A Class of

Decomposable Poverty Measures. Econometrica, 52, 761776. 
Friedman, J., \& Levinsohn, J. (2002). The Distributional Impacts of Indonesia's Financial Crisis on Household: A "Rapid Response" Methodology. World Bank Economic Review, 16, 397-423.

GOI. (2009). Iraq Council of Ministers Decision No. 369. Baghdad:

Government of Iraq. Retrieved from http://www.cabinet.iq/

Handa, S., \& King, D. (2003). Adjustment with a Human Face?

Evidence from Jamaica. World Development, 31(7), 11251145.

Heidhues, F., \& Obare, G. (2011). Lessons from Structural Adjustment Programmes and their Effects in Africa.

Quarterly Journal of International Agriculture, 50(1), 55-64.

Huang, K., \& Lin, B. (2000). Estimation of Food Demand and

Nutrient Elasticities from Household Survey Data. Food and

Rural Economics Division Technical Bulletin No. 1887,

Economic Research Service. Washington, DC: U.S.

Department of Agriculture.

IMF. (2013). Libya: Selected Issues. Washington, DC: International Monetary Fund (IMF).

Iraqi Parliament. (2017, September). Electronic PDS Card Law: First reading. Retrieved from ttp://ar.parliament.iq

Jensen, R., \& Miller, N. (2008). Do Consumer Price Subsidies Really Improve Nutrition? Center for International Development Working Paper 160. Harvard University.

Kaul, T. (2014). Household Responses to Food Subsidies: Evidence from India. Maryland: Working Paper, University of Maryland.

Kidd, S., Gelders, B., \& Bailey-Athias , D. (2017). Exclusion by Design: An Assessment of the Effectiveness of the Proxy Means Test Poverty Targeting Mechanism. ESS - Working Paper No. 56, Social Protection Department. Geneva: International Labour Orgzanization (ILO).

Minot, N., \& Goletti, F. (2000). Rice Market Liberalization and Poverty in Viet Nam. Washington, DC: IFPRI Research Report No. 114.

Muhammad, A., Seale, J. L., Meade, B., \& Regmi, A. (2011). International Evidence on Food Consumption Patterns: An Update Using 2005 International Comparison Program Data. 
USDA ERS Technica Bulletin No. 1929. Washington, DC: USDA.

Neary, J., \& Roberts, K. (1980). The Theory of Household Behaviour Under Rationing. European Economic Review, 13, 25-42.

Niimi, Y. (2005). An Analysis of Household Responses to Price Shocks in Vietnam: Can Unit Values Substitute for Market Prices? PRUS Working Paper No.30. University of Sussex.

Norad. (2011). We Accept Cash: Mapping Study on the Use of Cash Transfers in Humanitarian, Recovery and Transitional Response. Oslo: The Norwegian Agency for Development Cooperation (Norad).

Pistrup-Andersen, P., \& Alderman, H. (1988). The effectiveness of consumer-oriented food subsidies in reaching rationing and income transfer goals. In P. Pistrup-Andersen (Ed.), Food subsidies in developing countries: costs, benefits, and policy options. Baltimore: Johns Hopkins University Press.

Ramadan, R., \& Thomas, A. (2011). Evaluation the impact of reforming the food subsidy program in Egypt: a mixed demand approach. Food Policy, 36(5), 638-646.

Ryckembusch, D., Frega, R., Silva, M. G., Gentilini, U., Sanogo, I., Grede, N., \& Brown, L. (2013). Enhancing Nutrition: A New Tool for Ex-Ante Comparison of Commodity-based Vouchers and Food Transfers. World Development, 49, 58-67.

Sahn, D. (1987). Changes in the Living Standards of the Poor in Sri Lanka During a Period of Macroeconomic Restructuring. World Development, 16(6), 809-830.

Sdralevich, C., Sab, R., Zouhar, Y., \& Albertin, G. (2014). Subsidy Reform in the Middle East and North Africa: Recent Progress and Challenges Ahead. International Monetary Fund, Middle East and Central Asia Department. Washington, DC: International Monetary Fund.

Sen, A. (1981). Poverty and Famines: An Essay on Entitlement and Deprivation. Oxford: Clarendon.

Sibrian, R., Ramasawmy, S., \& Mernies, J. (2007). Measuring hunger at sub-national levels from household surveys using the FAO approach: Manual. Rome: FAO Statistics Division Working Paper Series No. ESS/ESSA/005e. 
Southworth, H. M. (1945, February). The Economics of Public Measures to Subsidize Food Consumption. Journal of Farm Economics, 38-66.

Subramanian, S. (2009). Poverty Measurement in the Presence of a "Group Affiliation Externality". Journal of Human Development, 10(1), 63-76.

Subramanian, S. (2012). The Focus Axiom and Poverty: On the Coexistence of Precise Language and Ambiguous Meaning in Economic Measurement. Economics: The Open-Access, Open-Assessment E-Journal, 6, 1-21.

Telleria, R., El-Hakim, A., Hassan, A., Dhehibi, B., Hatem, S., \& Rida, F. (2012). Agricultural Policies and Institutions in IraqA Historical Perspective. International Center for Agricultural Research in the Dry Areas (ICARDA).

Ulimwengu, J., Liverpool-Tasie, S., Randriamamonjy, J., \& Ramadan, R. (2011). Understanding the linkage between agricultural productivity and nutrient consumption: Evidence from Uganda. IFPRI Discussion Paper 01128. Washington, DC: International Food Policy Research Institute (IFPRI).

UN. (1991). Report to the Secretary-General on Humanitarian Needs in Kuwait and Iraq in the Immediate Post-Crisis Environment. New York: United Nations.

UN Security Council. (1990). Resolution 661: The Situation Between Iraq and Kuwait. New York: UN Security Council.

Upton, J., Cissé, J., \& Barrett, C. (2016). Food Security as Resilience: Reconciling Definition and Measurement. Agricultural Economics, 47, 135-147.

WFP \& GOI. (2012). Food Security, Living Conditions and Social Transfers in Iraq. United Nations Worls Food Programme and the Government of Iraq.

WFP. (2004). Baseline Food Security Analysis in Iraq. Rome: World Food Programme.

WFP. (2013). WFP And Iraq Government Aim To Introduce Electronic Food Vouchers [Press Release]. Retrieved from https://www.wfp.org/news/news-release/wfp-andgovernment-aim-introduce-electronic-food-voucher-pds WFP. (2014). Cash and Voucher Manual. Rome: The World Food Programme. Retrieved from https://www.wfp.org 
World Bank \& GOI. (2011). Confronting Poverty in Iraq. Washington, DC: World Bank and Iraq Poverty Reduction Strategy High Committee.

World Bank. (2005). Toward A More Effective Social Policy: Subsidies and Social Safety Net. Washington, DC: World Bank.

World Bank. (2007). Considering the Future of the Iraqi Public Distribution System. Washington, DC: Teh World Bank.

World Bank. (2008). Rising Food Prices: The World Bank's Latin America and Caribbean Region Position Paper . Washington, DC: The World Bank.

World Bank. (2011). Social protection for a changing India. Washington, DC: World Bank.

World Bank. (2014a). Iraq - The unfulfilled promise of oil and growth : Poverty, inclusion and welware in Iraq 2007-2012. Washington, DC: World Bank Group.

World Bank. (2014b). Poverty Estimates and Trends in Iraq: 20072012. Washington, DC: The World Bank.

World Food Summit. (2009). Rome Declaration World Food Security. World Food Summit. 


\section{Conclusion}

While organized as separate studies, a common thread runs throughout this thesis. This thread ties together the problem of determining the value of consumed subsidized food or food received in kind, the problem of assessing the impact of eliminating food assistance schemes on food and nutrient consumption and assessing whether monetary compensation equal to the estimated loss of welfare measured through typical economic approaches sufficiently mitigates impacts on food and nutrient consumption. The thread also weaves in evidence found in published literature on differential consumption responses to cash and food transfers, developing the concepts and applying an approach to perform ex ante cost effectiveness analysis of cash and food vouchers.

\section{Summary of Main Results}

The problem of determining the market value of subsidized goods is addressed in Chapter 2. Collecting and applying price data in expenditure surveys is perhaps one of the most error prone and ignored aspects of welfare measurement and analysis. This explains the body of literature and significant efforts invested in developing methods designed to deal with the drawbacks of unit values directly estimated from expenditure survey data. In the context of dual markets where goods can be purchased at subsidized prices up to a certain quota after which normal market prices apply, determining the prices of goods becomes yet more challenging.

This is true in the presence of commodity rationing and consumer subsidies as the prices paid by consumers for the good do not reflect true marginal utility of consumption. In such circumstances, subsidized good should be valued at their virtual price, which by 
definition, is the price level commensurate with the observed level of consumption.

However, technical difficulty in properly estimating the virtual prices of rationed goods led researchers to either ignore the issue altogether - such as in India or Libya - or to value rationed goods using prevailing prices in local markets such as in Indonesia, or to solicit price opinion data directly from survey respondents such as is done in Iraq. A review of over 100 questionnaires expenditure questionnaires applied in 36 countries between 1985 and 2017 that are listed in the World Bank's Living Standards Measurement Survey website shows that the use of price opinion data is a rather widespread practice. About 18 percent of the surveys collected price opinion data and the majority of the countries where price opinion data was collected either maintained or were in the process for reforming food subsidies or food rationing mechanisms.

However, little is actually known of the performance of price opinion data as a proxy for virtual prices and whether their use introduces biases in welfare analysis. Chapter 2 tests for any possible biases, hypothesizing that respondent opinions on market prices are influenced by the relative importance of the PDS subsidies in their household budget. Specifying a hierarchical model that explores the influence of both local market prices as well as household socio economic and demographic realities, Chapter 2 concludes that requesting consumers to directly provide their opinion of the market price of subsidized or rationed food commodities elicits biased responses.

Instead of reflecting market conditions, price opinions of subsidized food commodities reflect the importance of the subsidy in the household economy - a reflection of household welfare levels and preferences. For subsidized foods in Iraq, the transfer value of the subsidy, estimated as the difference between market price opinions 
and the official prices determined by the Government, decreases with rising household welfare but does not vary with market prices which is contrary to the expectation that the transfer value of the subsidy transfer rises with both quantity acquired and market prices.

Chapter 2 claims that price opinion data performs poorly as a measure of virtual prices of subsidized goods. For Iraq, analysis of consumption expenditures constructed using price opinion data for subsidized foods would point to a general deterioration in welfare levels between 2007 and 2011. This is at odds with the broad picture painted by various other indicators of wellbeing such as positive real wage growth, falling undernourishment and unemployment and significant improvements in safety and security overall. Consequently, Chapter 2 concludes that price opinion data for subsidized goods distorts the estimated transfer value of the PDS food subsidy and biases welfare analysis.

Accuracy in the estimation of the transfer value of a subsidy is important. It is, in effect, a form of income transfer, thus making its proper valuation important to economists and food security analysts alike. It is also fundamentally linked to the debate surrounding the effectiveness of food assistance schemes, such as subsidies, rationing or in kind food transfers compared with the more direct income transfer schemes, such as social cash transfers.

Chapter 3 examines this debate, which has been revitalized by increased use of cash assistance schemes in international development and humanitarian efforts as well as by the rising interest in exploring the role of social protection in addressing food security. Empirical evidence from United States addressing the effectiveness of food assistance and cash transfers particularly in relation to food stamp scheme, currently known and the Supplemental Nutrition Assistance Program (SNAP), has long argued that the food assistance scheme is more effective in inducing food consumption than cash 
transfers of equal value. The fact that the empirical evidence contradicted the prevailing theoretical economic thought on the economics of food assistance schemes perplexed analysts, eventually earning the phenomenon the title of "cash-out puzzle".

Chapter 3 compiles the evidence for the cash-out puzzle, accumulated over the course of 40 years from the United states, along with the very few studies from the developing world that compares the Marginal Propensity to Consume food from cash and food assistance. By recasting the evidence for the "cash-out puzzle" in terms of demand elasticity rather than marginal propensity to consume find that food demand due to food assistance is, on average, unit elastic, and with much less variance than the estimates of marginal propensity to consume. Estimating the same for Iraq produces a food assistance demand elasticity of 1.03. The empirical estimation for Iraq is particularly useful since examples from other contexts generally rely on data from transfer schemes that are targeted to the poorest members of society. The evidence from Iraq, however, is from a universal food subsidy to which both the poor and the relatively wealthy are entitled, thus offering the opportunity to examine the consumption responses across the spectrum of wealth.

Chapter 3 finds that the food assistance elasticity of demand for food in Iraq is virtually equal at the national and subnational levels, including across all deciles and finds that the results for Iraq are also statistically equivalent to results based upon published empirical works from the United States, Bangladesh and Zambia spanning a time period of 40 years.

Accordingly, Chapter 3 contends that the existing evidence essentially points to a suspension of Engel's law in relation to food consumption responses to food assistance. This implies that food transfers increase both food and non-food demand, yet leave the food budget share unaltered following the transfer. This is contrasted to an 
increase in regular cash income, or expenditure, where the food budget share generally decreases with rising income in accordance with Engel's law.

This is further utilized in elaborating an approach to undertake comparative cost effectiveness analysis evaluating the food consumption benefits of a food transfer relative to a cash transfer of equivalent value. Chapter 3 concludes that, with sufficient evidence for a unit elastic demand for food from food assistance, the reciprocal of the expenditure demand elasticity approximates the comparative cost effectiveness of a food transfer in relation to a cash transfer.

A unit elastic demand for food from food assistance also bears significance on the approach to assess the food and nutrient consumption implications of eliminating food subsidies. In this regard, Chapter 3 concludes that consumption responses to the elimination of food subsidies are appropriately captured through conditional demand elasticities.

The estimation of such demand elasticities is elaborated in Chapter 4, which addresses a critical gap in knowledge regarding consumer preferences over food and nutrients. Despite the ongoing planning and analysis by Government and international development partners in support of the PDS reform agenda, no attempt has been made to estimate a comprehensive set of food and nutrient demand elasticities for Iraq.

Seeking to address this critical gap, Chapter 4 presents the parameters of a complete food demand system for Iraq encompassing 42 food items and aggregate commodity groups. The food demand system estimation assumes a three stage budgeting process whereby households first allocate expenditures between food and non-food groups, followed by allocations between 8 food groups in the second 
stage, which are further disaggregated into 42 subgroups in the third stage.

To properly value subsidized PDS food commodities included in the demand system, virtual prices for the PDS goods virtual prices are estimated within the framework of the Normalized Quadratic Mixed Demand model, thereby allowing estimation of an unconstrained Quadratic Almost Ideal Demand System (QUAIDS) yielding "free" demand elasticities. The estimated QUAIDS models apply demographic scaling technique to accounts for varying demand as a result of household demographics and seasonality as well as apply appropriate methods to account for censoring of the data due to nonacquisition of specific food items during the survey reference period.

The estimated expenditure elasticities revealed in Chapter 4 include the full range of preferences, including mostly normal goods with positive expenditure elasticities less than unity as well as superior goods with positive expenditure elasticities higher than unity. Chapter 4 elaborates on PDS Rice and Commercial Wheat Flour demand elasticities, which found to inferior goods with the negative expenditure elasticities. The demand system also identifies Giffen Behavior in relation to PDS Rice. This is not observed for the poorest decile, however, which confirms similar findings from other studies.

Chapter 4 also presents nutrient expenditure and price elasticities for a list of macro and micronutrients, which are found to be expenditure and price inelastic, though increasing in total expenditure for most nutrients. PDS Wheat Flour, which is the cheapest and largest contributor to total calorie consumption, is estimated to have positive nutrient price elasticities, suggesting that households are able to substantially mitigate price shocks on their calorie intake through substitution. 
Chapter 5 relies on the estimated demand system parameters from Chapter 4 and incorporates the main conclusions from Chapter 3 to apply an approach to simulate the effects of food subsidy reform on welfare and food security, as well as the effects of replacing subsidies with a targeted cash or food voucher transfer mechanism.

Significant increases in the prices of PDS goods, rising from their estimated virtual prices up to observed market prices of commercial equivalents, is expected lead to 24 percent rise in the cost of living resulting in a 30.5 percent fall in welfare, on average, relative to average pre-reform welfare levels as measured by Compensating Variation. Poorest members of the Iraqi population will experience greater relative loss of welfare, estimated at 48 percent of pre-reform expenditure levels for the poorest decile - although this proportion remains fairly high even for the wealthiest decile where it is estimated at 18.4 percent of pre-reform expenditure levels.

The aggregate monetary value of the measure of Compensating Variation applied in Chapter 5 is estimated at US\$16.75 billion, which is especially high relative to actual Government expenditures on PDS subsidies, which stood at US\$4.93 billion in 2012. This is further corroborated by estimating the total private consumption expenditure equivalent of US\$4.93 billion worth of food consumption, which is also estimated at US\$16.78 billion.

Applying conditional nutrient elasticities, it is found that eliminating PDS subsidies is simulated to lead to a fall in average calorie consumption from 3,065 observed in 2012 down to 2,607 kilocalories per person daily. The rate of reduction in calories is 15.4 percent nationally, which remains within the range of 13.7 and 16.4 across deciles, which indicates that households, particularly in the lower end of the wealth spectrum apply coping strategies to safeguard their calorie consumption. Eliminating PDS subsidies, however, exhibits greater impact on micronutrients than macronutrients and more so among the poorest Iraqis compared with the wealthier groups. 
Accordingly, Chapter 5 characterizes the effects of eliminating PDS subsidies as inducing a significant shift in consumption away from the relatively more expensive micronutrient rich foods towards the relatively cheaper calorie rich foods.

Chapter 5 further simulates the impact of eliminating PDS subsidies on the prevalence of poverty and undernourishment, estimating a rise in poverty from 19.8 percent up to 39.4 percent and arise in undernourishment from 4.8 percent up to 13.3 percent.

Comparative nutritional cost effectiveness analysis of a cash transfer scheme and a food voucher scheme is also performed using the Omega Value typically applied by the World Food Programme to determine appropriate food transfer mechanisms. Guided by the results of Chapter 3, the analysis finds food vouchers to be 21 percent more nutritionally cost effective than cash transfers even after accounting for the different administrative costs associated with cash and food vouchers.

Simulations of the expected impacts of a poverty targeted cash transfer and a similarly targeted food voucher transfer finds the transfer value that is equal to the estimated Compensating Variation to adequately mitigate the effects of PDS reform in poverty, though it does leave the prevalence of undernourishment higher post transfer than its estimated baseline value. In contrast, the defined cash transfer scheme is simulated to completely reverse the rise in the national poverty rate, effectively reducing the prevalence from 39.4 percent following the elimination of subsidies down to 19.5 percent.

The results presented in Chapter 5 underline the possibility that the investment required to prevent poverty from rising following the elimination of food subsidies is higher than the cost of maintaining the subsidy. They also underline the likelihood that food insecurity will deteriorate in the aftermath of eliminating food subsidies in Iraq, even if poverty is prevented from rising through cash transfers. 


\section{Contribution to Literature}

This dissertation contributes to a number of bodies of literature, including welfare measurement, "cash-out puzzle", nutritional cost effectiveness analysis and food security policy analysis.

Chapter 2 contributes to the welfare measurement literature by presenting evidence on the limitations of respondent price opinions in the context of food subsidies and rationing. The analysis shows that though price opinions of subsidized goods are inconsistently associated with the market prices of their unsubsidized, free market equivalents and lead to biases in the measurement of poverty trends over time. The implication of this in the context of Iraq is the tendency to underestimate the income transfer value of food subsidies thereby underestimating welfare levels.

Chapter 3 contributes to the "cash-out puzzle" literature through the demonstration the elasticity of demand for food due to food assistance is approximately equal to 1 , which implies that households receiving food assistance do not consider it as an income source. Therefore, food assistance does not trigger the same consumption responses as a cash transfer would, including the reduction in the share of total budget allocated to food as stipulated by Engel's Law. This finding has eluded empirical analysts concerned with the "cashout puzzle" in the United States as most analysts followed the tradition in this body of literature of estimating the Marginal Propensity to Consume due to food assistance rather than estimating elasticities. This dissertation also adds to the existing evidence on the "cash-out puzzle" by directly estimating the elasticity of demand for food due to food assistance in Iraq - estimated at 1.03 nationally. The elasticity estimated at subnational levels, including for rural and urban communities as well as separately for each wealth decile have all ranged between 1.026 and 1.033 which indicates that the underlying driving influence for the "cash-out puzzle" is essentially constant. 
Furthermore, these findings represent a substantial contribution to the growing literature focused on cash and food transfer cost effectiveness analysis and the broader debate on the effectiveness of cash versus vouchers and in kind transfers. The difference in consumption responses to cash and food assistance is utilized in defining a broad measure of comparative cost effectiveness evaluating the food consumption benefits of a food transfer relative to a cash transfer of equivalent value. Specifically, the reciprocal of the expenditure demand elasticity $(\eta)$, normally estimated through a simple single equation model, is proposed as a proxy measure of comparative cost effectiveness of a food transfer in relation to a cash transfer under the assumption that the elasticity of demand for food due to food assistance is approximately equal to 1 .

Chapter 4 of this dissertation contributes to the large body of literature presenting country estimates of food demand systems and to the growing body of literature presenting country estimates of nutrient demand elasticities. This is particularly novel for Arab States, the majority of which do not have any published information on the structure of food demand and none of which have any published information on the structure of nutrient demand. Therefore, this paper helps bridge this critical gap by presenting a complete food demand system for Iraq encompassing 42 food items and aggregate commodity groups. The food demand system estimation proceeds assuming a three stage budgeting process whereby households first allocate expenditures between food and non-food groups, followed by allocations between 8 food groups in the second stage, which are further disaggregated into 42 subgroups in the third stage, with each group containing between 3 and 7 sub groups.

A further contribution of this paper is the identification of Giffen behavior in relation to PDS Rice - a result that echoes similar results for Rice found by Jensen and Miller (2007) for Urban poor population in China. This implies that Giffen behavior in relation to 
subsidized staple goods may be more common than is currently acknowledged.

Chapter 5, which builds heavily on the findings of the preceding chapters contributes to the broad food security policy analysis literature, to the debate on the effectiveness of cash versus vouchers and in kind transfers and sheds light onto the differences in welfare and food security effects of subsidy reform processes where universal food consumption subsidies are replaced with targeted cash transfers.

Regarding the food security policy analysis literature, this dissertation demonstrates a novel approach to undertaking ex ante food security policy impact analysis as well as ex ante cost effectiveness analysis of cash and food vouchers. Utilizing food and nutrient demand elasticities as well as empirical evidence of a higher elasticity of demand for food due to food assistance, this dissertation expands the application of the Omega Value cost effectiveness analysis metric to cash and value based food vouchers.

The dissertation also contributes to advance the understanding of the differential impacts of food subsidy reform on welfare and food security, asserting that typical compensation measures can fail to fully mitigate the effects of food subsidy reform on the prevalence of undernourishment even while fully mitigating the effects of food subsidy reform on the prevalence of poverty. This dissertation claims that differences in welfare and food security effects emanate not only from methodological differences in measuring poverty and undernourishment, but also from conceptual differences between the constructs of food insecurity and poverty.

\section{Implications for Food Security Policy Analysis}

Overall, combining the evidence from the various chapters of this thesis presents substantive insights that are useful to national and 
international institutions focused on food assistance. Food transfers have traditionally been criticized on the grounds of being patronizing and inconsiderate of the preferences of its intended recipients. For in kind food transfers, this critique is, in fact, reasonable. The impracticality of designing in kind food baskets that meet the needs and preferences of all recipients necessarily creates the conditions where quantities received by at least some of households are extramarginal - thereby unnecessarily and wastefully increasing their consumption of goods within the food basket. However, this critique cannot be extended to include value based food vouchers, which offer the recipient the flexibility to acquire the food that they prefer.

For food voucher transfers, the cash-out puzzle is not so much related to the fact that they induce greater food consumption as much as it is a lack of understanding of the reasons why recipient households choose to consume more food despite the fact that they are not compelled to do so. Much of the "cash-out puzzle" literature therefore has focused on trying to explain this seemingly irrational choice. The analysis presented in this thesis shows that a food voucher transfer increases consumption of food and non-food goods in line with their pre-transfer preferences, leaving their Engel ratio unchanged. Food vouchers therefore offer the recipients the opportunity to consume food exactly as they would have had it been a cash transfer, or to consume the quality and quantity of food normally attainable at a higher budget constraint. Empirical evidence shows that consumers are more likely to choose the latter.

The implication, therefore, relates to the design of policy instruments and intervention tools that specifically aim to address food insecurity and undernutrition. Specifically, the evidence presented in this dissertation implies that cash transfers are not necessarily the best option especially where genuine food security and nutrition goals or targets are pursued and - at the very least - should be subject to an ex 
ante cost effectiveness analysis such as that performed in this dissertation.

Related to this is the finding that compensation measures that appear to mitigate the rise of poverty following lifting food subsidies is likely insufficient to mitigate the resultant rise in food insecurity. This paper proposes that this can be attributed to fundamental differences in the construction of poverty and food security measures. While typical poverty measures focus by design on the conditions of the population below the poverty line, food security is argued to be a population-wide phenomenon that is influenced in large part by the conditions at the lower end of the wealth distribution, though is also influenced by consumption levels among the middle and wealthier groups as well as to inequality in consumption due to income disparities. The research in this thesis proposes that this helps explain why food insecurity was found to deteriorate in so many cases following ostensibly welfare-inducing market liberalization policies.

\section{Limitations and Opportunities for Future Extension}

While every effort is made to widen the relevance of the dissertation to a broader context, the fact that the analysis relies heavily on the Iraq context is a clear limitation of this dissertation. Of course, Iraq is not the only resource rich country suffering from chronic instability and violence, though it does possess a unique combination of wars, international sanctions and resource base. Nonetheless, much of the results presented in this dissertation are not necessarily restricted to conflict prone countries. Therefore, similar analysis performed in other contexts can serve to confirm the findings found here, particularly in more stable contexts.

Another limitation of the policy impact simulations performed in the dissertation relates to the fact that it reflects a partial and incomplete 
picture of the full extent of the potential impacts throughout the economy as a whole. Macro level general equilibrium models with links to microsimulation models of the household sector are more adept at capturing the full extent of potential impacts. Indeed, these methods are under-utilized in the developing world and represents an opportunity for further research.

There are also other candidates for further research that builds upon the findings in this dissertation. This includes exploring whether the "cash-out puzzle" applies to food only, or whether it applies to other consumer goods that are subsidized or distributed in kind. This also includes exploring the possibility that Giffen behavior in relation to subsidized staple goods may be more common than is currently known. 


\section{Valorisation Addendum}

The research contained in this dissertation is relevant to the debate surrounding the relative merits of cash and food transfers with the goal of supporting policy analysis and policy design of national safety nets as well as international humanitarian and international aid.

Utilizing data collected from the context of Iraq, where the largest universal food subsidy and rationing mechanism remains operational to this day, specific facets of the questions surrounding the effectiveness of cash versus food transfer modalities - such as the valuation of food subsidies, differential consumption responses due to alternative transfer modalities and the estimation of food demand parameters in the presence of subsidies and rationing - are explored.

The results of the analysis presented in this thesis are directly relevant to a lively debate currently being held in Iraq among practitioners, policy makers, academics and parliamentarians. Despite the reliance on data from Iraq, the methodological approaches and suggestions contained within this dissertation extend its relevance to contexts well beyond Iraq to many developed and developing countries that continue to grapple with important questions surrounding effectiveness of cash versus food transfers. The decades-old literature on the cash-out puzzle in the United States remains active to this day and many international organizations and donors have caught onto its relevance for their important work in humanitarian emergencies and in development contexts.

As humanitarian organizations such as WFP and others have expressed goals to increase their cash and voucher activities, donors have asked difficult questions regarding the cost effectiveness of different transfer modalities. For example, the UK's Department for International Development (DFID) very recent Humanitarian Reform Policy committed to prioritize cash over vouchers and DFID is currently exploring possibilities for Value for Money analysis of "Multi-Purpose Cash Transfers" in the context of humanitarian crises. 
This dissertation develops and applies a stylized nutritional cost effectiveness analysis approach specific to cash and food vouchers. This approach extends the methods currently applied by the World Food Programme (WFP) in assessing the relative merits of in kind transfers and food vouchers. This simple yet theoretically sound approach would enable WFP and other organizations to extend their comparative cost effectiveness analysis to cash transfers.

Food subsidies and rations are a form of income transfer, thus making its proper valuation important to economists and food security analysts alike. This dissertation sheds light on important aspects of estimating the transfer value of a food subsidy, particularly where price opinion data is utilized. Although non practitioners rarely consider the type of price data, economists are often concerned with the type of price data to utilize in welfare analysis. Given the difficulty to collect accurate and comprehensive price data during household budget surveys, this thesis finds that many surveys resort to asking for price data directly from the survey respondents - many of these instances are also in contexts where food subsidies and rationing existed. Yet we find that using price opinion data in the context food subsidies and rationing likely biases the estimated transfer value of the subsidy. That the valuation decreases with increasing wealth is found to lead to wrong conclusions about poverty trends over time.

This dissertation also explores the debate surrounding cash and food transfers in light of evidence for the "Cash-out Puzzle" that has accumulated over the course of 40 years from the United states. By recasting the evidence for the "cash-out puzzle" in terms of demand elasticity rather than marginal propensity to consume find that food demand due to food assistance is, on average, unit elastic, and with much less variance than the estimates of marginal propensity to consume. Estimating the same for Iraq produces a food assistance demand elasticity of 1.03 and with subnational elasticities, including for rural and urban communities and across wealth deciles all 
essentially the same and not significantly different from the national average - leading to the conclusion that the underlying driving influence for the "cash-out puzzle" is essentially constant.

This dissertation highlights an important, yet commonly overlooked difference between cash transfers, food vouchers and in kind food transfers. The latter have traditionally been criticized for being patronizing and blind to the preferences of its recipients. While this is a fair and reasonable critique of in kind food baskets, it is not fair to extend this critique to value based food vouchers, which offer the recipient the flexibility to acquire the food that they prefer.

The "cash-out puzzle" is not so puzzling for in kind transfers as it is clear how they induce greater food consumption even when not desired or required. Yet, for food vouchers, the "cash-out puzzle" is indeed perplexing, as the underlying reason behind the seemingly irrational choice to consume more food despite the freedom to do otherwise simply cannot be explained by the widely accepted theories currently at our disposal.

The evidence presented in this dissertation allude to the possibility that this may be a result of a previously undocumented failure of Engel's Law. Whether that is the case and whether it may extend to other forms of income transfer will define the challenge of research to come.

Finally, the food demand parameters estimated in this dissertation are a valuable tool that can be further utilized in important policy analysis in Iraq. The Iraqi Tariff law, passed by the Iraqi parliament, yet never put into full practice due to fears of uncontrolled price inflation is a clear candidate for further research. In addition, the identification of Giffen behavior in relation to the subsidized staples, similar to that observed by recent research in China, suggests that this form of behavior may be more common than currently documented - a proposition that merits further research. 


\section{Summary}

Governments traditionally played a major role in maintaining national food security (Pinstrup-Andersen, 1988). However, over the past few decades, national food assistance schemes have witnessed a profound transformation. Universal, untargeted food consumption subsidies were deemed an inefficient use of resources (Pinstrup-Andersen, 1988; FAO, 1994) and were argued to distort markets, induce disincentives for agricultural production and private sector food trade and suffered inefficiencies in their public sector managed supply chains (del Ninno, Dorosh, \& Subbarao, 2007).

International food aid has also witnessed significant transformations during the past two decades. Until the late 1990s, international food aid was largely limited to a system of in kind food donations from donor countries with agricultural surpluses to recipient countries experiencing chronic or acute food deficits (Barrett \& Maxwell, 2005). However, the scarcity of in kind food donations led in kind food aid to become increasingly limited to acute humanitarian emergencies. Traditional food aid donors have become increasingly flexible with more donors willing to donate funds rather than food commodities to address the worlds acute and chronic food insecurity. This flexibility offered WFP and other multilateral food assistance agencies the opportunity to rely more on markets closer to the recipient population for the procurement of food and procurement from small scale farmers.

One consequence of these changes in national and international food assistance is the blurring of the lines between the role of traditional food assistance schemes and the 'new social protection agenda' which is dominated by social transfers, with cash transfers increasingly displacing food assistance (Devereux, 2009). This, along with the increased reliance on cash and vouchers by 
multilateral organizations, has led to the recognition that social protection systems and food assistance programs serve overlapping goals (Devereux, 2016).

However, the relative merits of cash and food transfers as food assistance mechanisms and the unique impacts that each may bear are not fully understood. Often, cash is simply considered to be the more efficient and cost effective transfer modality, particularly in the presence of functioning markets. Most response analysis tools and processes applied by international aid organizations almost automatically prescribe cash transfers in the presence of functioning markets, whereas specialized organizations with specific food and nutrition security mandates such as WFP, FAO and ACF only advocate 'considering' cash or a combined cash and food transfer.

This thesis explores the relative merits of cash and food transfers in enhancing wellbeing and macro and micronutrient consumption. Though all collectively contribute to the overall research domain of this dissertation, the chapters of the dissertation are distinct studies, each addressing distinct empirical research questions using survey data collected in Iraq. Chapter 2 explores the challenge of estimating the value of food assistance, focusing on the appropriateness of respondent-estimated market price opinion data of rationed and subsidized commodities.

This chapter concludes that price opinions of subsidized food commodities do not necessarily reflect market conditions and are influenced by the importance of the subsidy in the household economy - a reflection of household welfare levels and preferences. Additionally, respondent price opinions of subsidized commodities and by extension the transfer value of the subsidy - decreases with increased income. This is argued to have a biasing effect on welfare analysis. The choice of price data leads to different trends in the growth of consumption expenditure and poverty over time. The results of the estimation models indicate that the transfer value from subsidized commodities, on the whole, decreases with increased 
income and with increased market prices, thus counteracting any increase in income and artificially deflating consumption expenditure.

Chapter 3 focuses on empirical evidence on the nutritional cost effectiveness of cash versus food transfers as part of food assistance programmes, utilizing existing evidence mainly from the United States, but also from Bangladesh and Zambia, and contributes additional empirical evidence from the Iraqi context. Specifically, this chapter explores the evidence on the differences in consumption responses following a food or a cash transfer and how that difference can be employed to measure the ex-ante cost effectiveness of cash and food transfers.

By expressing the marginal propensity to consume food due to food assistance in terms of income demand elasticity, this chapter finds a remarkable reduction in variability of estimates found in 16 published studies, clustering the estimates close to the mean food assistance elasticity equal to unity. Estimating the same using data from Iraq produces a food assistance demand elasticity approximately equal to unity (1.03). This chapter concludes that households generally leave the food budget share unaltered following a food the transfer, in contrasted to an increase in regular cash income, or expenditure, where the food budget share generally decreases with rising income in accordance with Engel's law. This is further utilized to suggest a stylized approach to undertake ex ante comparative cost effectiveness analysis of cash and food assistance.

Chapter 4 applies quantitative food demand modelling approaches to investigate the dynamics of demand for food and nutrients in the presence of food consumption subsidies. This chapter estimates and discusses the parameters of a complete food demand system for Iraqthe first of its kind for Iraq or any other Arab State. The food demand system estimation follows a three stage budgeting approach, allowing the estimation of expenditure and own and cross price demand elasticities for 42 food commodities and commodity groups. First stage demand parameters are estimated through a Working-Leser model and the second and third stages are estimated using the 
Quadratic Almost Ideal Demand System (QUAIDS) adjusted to account for demographic scaling and censored expenditure data. Subsidized food commodities are valued at their virtual prices estimated as the derivative of the cost function specified in the Normalized Quadratic mixed demand model. Furthermore, expenditure and price elasticities of demand for eight macro and micro nutrients are estimated to allow the assessment of nutrient intake responses due to price and income shocks.

Most commodities are estimated to be normal goods with positive expenditure elasticities, though less than unity, while some commodities, such as Commercial Vegetable Oil, Commercial Sugar, Mutton, Beef and Milk are considered superior goods with positive expenditure elasticities higher than unity. The model results reveal that subsidized, ration rice and commercial wheat flour are considered inferior goods. The estimated price elasticities indicate substantial price responsiveness of demand for commercial food subgroups including rice, wheat flour, sugar, and breads and buns among others.

The model also identifies giffen behavior in relation to subsidized, rationed rice with a negative expenditure elasticity and a positive own price elasticity. This echoes the results of other published works that identify giffen behavior in relation to subsidized rice in Urban china. This suggests that giffen behavior may be common for subsidized staple foods, which has significant implications for policy analysis assessing the impacts of eliminating food subsidies.

Chapter 5 applies microsimulation methods to assess the expected impacts of food consumption subsidy reform on welfare and food security and explores the comparative cost effectiveness of alternative transfer modalities such as cash and food vouchers. This chapter relies heavily on the food and nutrient elasticities estimated in Chapter 4 as well as the findings of Chapter 3 on the differential consumption responses to a food and cash transfer.

In this chapter, the distributional, welfare and food security impacts of eliminating Iraqi food consumption subsidies are estimated where 
welfare effects are captured through Compensating Variation and simulated poverty headcount index and food security effects are captured through the simulated change in macro and micronutrient consumption and simulated prevalence of undernourishment.

Lifting food consumption subsidies are simulated lead to a 24 percent rise in the cost of living resulting in a 30.5 percent fall in welfare relative to average pre-reform welfare levels as measured by Compensating Variation (CV), though the effects are felt more intensely by the poorer segments of Iraqi society as the poorest decile is expected to experience a 48 percent loss of welfare.

Average calorie consumption is simulated to fall from 3,065 to 2,607 kilocalories per person daily. However, the effects of eliminating subsidies on nutrient consumption is most pronounced for micronutrients among members of the poorest deciles where the consumption response is characterized by a large shift in consumption away from expensive micronutrient rich foods towards the relatively cheaper calorie rich foods. Simulation presented in this chapter indicate that eliminating subsidies would increase the prevalence of undernourishment from 4.8 percent up to 13.3 percent if the reform process is unaccompanied by any mitigation measures. Similarly, poverty is simulated to rise from 19.8 percent to 39.4 percent nationally following the elimination of subsidies.

The ex-ante cost effectiveness analysis performed in this paper confirms that value based food vouchers are 21 percent more cost effective than cash transfers in improving consumption of both macro and micro nutrients. In addition, simulations presented in Chapter 5 indicate that a poverty targeted food voucher or a cash transfer equal to the amount suggested by the Compensating Variation reduces post subsidy elimination undernourishment from 13.3 to 6.2 percent, which is higher than the baseline prevalence. In contrast, the same cash transfer scheme is simulated to completely reverse the rise in the national poverty rate, returning the national prevalence from the high of 39.4 percent following the elimination of subsidies down to 19.5 percent, which is equal to the baseline prevalence. 
The results presented in Chapter 5 suggest that, on aggregate, the monetary measure of welfare loss due to eliminating food consumption subsidies can be far larger than the cost of maintaining them. This raises questions on the efficiency of replacing universal subsidy schemes with targeted cash or food voucher transfer schemes. In addition, the chapter concludes that mitigation schemes that may be effective in reversing the poverty effects of eliminating food consumption subsidies are not necessarily sufficient to reverse the resulting rise in undernourishment. For Iraq, the elimination of subsidies and the compensation of the poor with a cash transfer or a food voucher transfer can result in an Iraq that is no less poor, though generally more food insecure. 


\section{Curriculum Vitae}

Tareq Abuelhaj was born in 1977 in California, USA, though soon afterwards moved with his family to East Jerusalem. Mr. Abuelhaj graduated High School in Ramallah, Palestine before attending college in the United States where he completed his undergraduate studies in Biology from Earlham College in 1999. Mr. Abuelhaj completed his Master's Degree in Social Science Data Collection \& Analysis, with distinction, from the University of Essex in Colchester, UK in 2008 and joined the Maastricht University Graduate School of Governance in 2012.

Mr. Abuelhaj has fifteen years of professional experience in social protection and solutions to poverty and food insecurity, working with organizations such as the World Food Programme, the Food and Agriculture Organization, the Geneva University Institute of Development Studies and Development Pathways Ltd.

Mr. Abuelhaj specializes in food security and social protection policy and operations, poverty and food insecurity measurement and policy impact analysis and has worked closely with Governments and development partners on issues such as food subsidy reform, social protection policy reform, designing of targeting criteria and the design of electronic cash and voucher transfer mechanisms. 


\section{UNU-MERIT/MGSoG Dissertation Series}

2018

Marta Férnandez de Arroyabe

Arranz

Essays on MEAS and Innovation

UNU-MERIT/MGSoG Dissertation

Series № 207

\section{Clotilde Mahé}

Essays on Migration and Occupational

Choice

UNU-MERIT/MGSoG Dissertation

Series № 206

\section{Simone Sasso}

Talent on the move. Essays on Human

Capital, Graduate Mobility and

Economic Development

UNU-MERIT/MGSoG Dissertation

Series № 205

\section{Khaled Walid Rajab}

Strategic Planning under Fragility

UNU-MERIT/MGSoG Dissertation

Series № 204

\section{Mutinta Hambayi Nseluke}

A Tall Order: Improving Child Linear

Growth

UNU-MERIT/MGSoG Dissertation

Series № 203

\section{Elvis Korku Avenyo}

Innovations and Firm Performance

in sub-Saharan Africa: Empirical

Analyses

UNU-MERIT/MGSoG Dissertation

Series № 202

\section{Ni Zhen}

Employment Dynamics, Firm

Performance and Innovation

Persistence in the Context of

Differentiated Innovation Types:

Evidence from Luxembourg

UNU-MERIT/MGSoG Dissertation

Series № 201

\section{Caroline Wehner}

Too Scared to Achieve: The Relation

Between Neuroticism,

Conscientiousness

and Socioeconomic Outcomes

UNU-MERIT/MGSoG Dissertation

Series № 200

\section{Stefania Innocenti}

On Institutional Persistence

UNU-MERIT/MGSoG Dissertation

Series № 199 


\section{Hassen Abda Wako}

Economic Globalization, Institutions and Development: Essays on Aid, Foreign Direct Investment and Trade UNU-MERIT/MGSoG Dissertation Series № 198

2017

\section{Hans-Erik Edsand}

Winds of Change

UNU-MERIT/MGSoG Dissertation

Series № 197

\section{Ana Patricia Silva Vara}

Redressing the Gender Gap

UNU-MERIT/MGSoG Dissertation

Series № 196

\section{Andrés Iván Mideros Mora}

Essays on the Economic Effects of Noncontributory Social Protection

UNU-MERIT/MGSoG Dissertation Series № 195

\section{Tobias Broich}

New Actors in the Global Economy UNU-MERIT/MGSoG Dissertation Series № 194

\section{Bernard Nikaj}

From No-government to E-government UNU-MERIT/MGSoG Dissertation Series № 193
Ali Safarnejad
Prioritizing the HIV Response
UNU-MERIT/MGSoG Dissertation
Series № 192

\section{Clovis Freire}

Diversification and Structural

Economic Dynamics

UNU-MERIT/MGSoG Dissertation

Series № 191

\section{Michael Verba}

Innovation and Knowledge Dynamics:

Essays on the Knowledge Economy

UNU-MERIT/MGSoG Dissertation

Series № 190

\section{Pui Hang Wong}

The Hearts and Minds in Conflict and Peace: The Economics of

Counterinsurgency and the Psychology of Reconstruction

UNU-MERIT/MGSoG Dissertation

Series № 189

\section{Brenda Yamba}

Schooling Despite All Odds: Evidence from Lesotho on Female Child Carers who Stayed in School UNU-MERIT/MGSoG Dissertation Series № 188

\section{Sheng Zhong}

Moving towards An Energy Efficient Future: Essays on Energy Efficiency, Technology and Development UNU-MERIT/MGSoG Dissertation Series № 187 


\section{Julieta Marotta}

Access to Justice and Legal

Empowerment of Victims of Domestic

Violence through Legal Organizations

in the City of Buenos Aires: A

Qualitative Empirical Legal Study

UNU-MERIT/MGSoG Dissertation

Series, № 186

\section{Andrea Franco-Correa}

On the Measurement of

Multidimensional Poverty as a Policy

Tool: Empirical Applications to Chile,

Colombia, Ecuador and Peru

UNU-MERIT/MGSoG Dissertation

Series, № 185

2016

\section{Yesuf Awel}

Insurance for Growth: Empirical

Essays on Insurance Demand and

Impacts in Africa

UNU-MERIT Dissertation Series,

№ 108

\section{Tigist Mekonnen Melesse}

Grow More Food using Fewer

Resources: Agricultural Technology

Adoption and Innovation Practices for

Inclusive and Sustainable

Development

UNU-MERIT Dissertation Series, № 107

\section{Eleni Yitbarek}

Getting Ahead or left Behind? Essays

on Poverty Dynamics and Social

Mobility in Africa

UNU-MERIT Dissertation Series,

№ 106

\section{Thuy Dieu Nguyen}

Firm-Level Theory and Evidence of

Corruption

UNU-MERIT Dissertation Series, № 105

\section{Raquel Tsukada Lehman}

Essays on Household Production with

Labor-Saving Technology

UNU-MERIT Dissertation Series,

№ 104

\section{Eva Barteková}

Multi-Problem Challenges for a

Renewable Future: Empirical Studies

on Competitive Disadvantages from

Electricity Price Differentials and

Mineral Supply Risk in an Open

Economy

UNU-MERIT Dissertation Series, № 103

\section{Jocelyn Olivari}

Entrepreneurial Traits and Innovation:

Evidence from Chile

UNU-MERIT Dissertation Series,

№ 102

\section{Muhammad Shafique}

Essays on the role of knowledge, RED, and Technology-based Firms in the Evolution of Socio-techno-economic System

UNU-MERIT Dissertation Series, № 101 


\section{Serdar Türkeli}

Governance of Innovation Policy:

Empirical Studies on Applied Political

Economy by Multi-Methods Analysis

UNU-MERIT Dissertation Series,

№ 100

\section{Ayokunu Adedokun}

Pathways to Sustainable Peace

building in Divided Societies: Lessons

and Experiences from Mozambique

MGSoG Dissertation Series, № 75

\section{Luiz Rothier Bautzer}

Organizing Concurrent Engineering

through ICT Platforms

Blueprinting Product Lifecycle

Management Platforms across

Disciplinary Agencies

MGSoG Dissertation Series, № 74

\section{Natalia Popova}

Migration in the Periphery of the

European Union:

Determinants of Successful and

Sustainable Labour Market Integration of Return Migrants in Albania, Egypt, Moldova and Tunisia

MGSoG Dissertations Series, № 73

\section{Richard A. Martina}

Uncertainty and Resource Constraint in the Small Island Developing States: Essays in Entrepreneurial Cognition MGSoG Dissertations Series, № 72

\section{Cécile Cherrier}

The Expansion of Basic Social

Protection in Low-income Countries:

An Analysis of Foreign Aid Actors'

Role in the Emergence of Social

Transfers in Sub-Saharan Africa

MGSoG Dissertations series, № 71

\section{Paul Caldron}

The Tacit Bargain in Short-Term

Medical Missions: Why U.S.

physicians go and what it costs

MGSoG Dissertation Series, № 70

\section{Mahmut Kobal}

Customs \& Excellence: A Comparative Approach on Administrative and Regulatory Compliance Perspectives of the EU-Turkey Customs Union

MGSoG Dissertation Series, № 69

\section{Craig Loschmann}

Essays on Conflict-related Migration and Development in the Case of

Afghanistan

MGSoG Dissertations Series, № 68

\section{Andrea Milan}

Rural Livelihoods, Location and

Vulnerable Environments: Approaches to Migration in Mountain areas of

Latin America

MGSoG Dissertation Series, № 67

\section{Farida Lada}

On Guarding the Welfare of Clinical

Trial Subjects While Promoting Novel

Drug Innovation

A Game Theoretical Approach

MGSoG Dissertation Series, № 66 


\section{Hibret Belete Maemir}

Dissecting Aggregate Productivity:

International Integration and Growth

with Heterogeneous Firms

UNU-MERIT Dissertation Series, № 96

\section{Giorgio Triulzi}

Looking for the Right Path: Technology

Dynamics, Inventive Strategies and

Catching-up in the Semiconductor

Industry

UNU-MERIT Dissertation Series, № 95

\section{Abdul Baseer Qazi}

Knowledge flows and networks in the ICT sector: The case of Pakistan UNU-MERIT Dissertation Series, № 94

\section{Ajay Thutupalli}

Technology Paradigm Shifts in Agriculture: Drivers of Sustainability and Catch up

UNU-MERIT Dissertation Series, № 93

\section{Eduardo Urias}

Improving access to HIVIAIDS

treatment in Brazil: When are

Compulsory Licenses effective in Price Negotiations?

UNU-MERIT Dissertation Series, № 92
Why have so few Countries

Industrialised?

UNU-MERIT Dissertation Series, № 91

\section{Daniel Opolot}

The Evolution of Beliefs and Strategic

Behaviour

UNU-MERIT Dissertation Series, № 90

\section{Alejandro Lavopa \\ Structural Transformation and \\ Economic Development: Can \\ Development Traps be Avoided \\ UNU-MERIT Dissertation Series, № 89}

\section{Jinjin Zhao}

Urban water management reform: The Case of China

UNU-MERIT Dissertation Series, № 88

\section{Simona Vezzoli}

Borders, Independence and Postcolonial Ties: the Role of the State in Caribbean Migration

MGSoG Dissertation Series, № 65

\section{Silvia Consuelo Gómez Soler}

Civil Conflict and Education: How

Does Exposure to Civil Conflict Affect

Human Capital Accumulation?

Evidence from Standardized Exit

Exams in Colombia

MGSoG Dissertation Series, № 64 


\section{Paula Nagler}

Occupational Choice in the Developing

World

MGSoG Dissertation Series, № 63

\section{Jasmin Kientzel}

Determinants of Professional

Commitment to Environmental

Sustainability

MGSoG Dissertation Series, № 62

\section{Mehmet Güney Celbiş}

Regional Policies: Convergence, Trade, and the Allocation of Public Capital

MGSoG Dissertation Series, № 61

\section{Florian Henning}

Living Up to Standard:

Interoperability Governance and

Standards Adoption in Government

Information Networks

MGSoG Dissertation Series, № 60

\section{Niels P. Groen}

The Never-Ending Project

Understanding E-Government Project

Escalation

MGSoG Dissertation Series, № 59

\section{Derek Copp}

Teacher-Based Reactivity to Provincial Large-scale Assessment in Canada MGSoG Dissertation Series, № 58

\section{Michaella Vanore}

Family-Member Migration and the Psychosocial Health Outcomes of Children in Moldova and Georgia MGSoG Dissertation Series, № 57

\section{Sonja Fransen}

The Economic and Social Effects of Remittances and Return Migration in Conflict-Affected Areas: The Case of Burundi

MGSoG Dissertation Series, № 56

\section{Ibrahim Khalil Conteh}

The Impact of Floods on Primary

School Education in Zambia

MGSoG Dissertation Series, № 55

\section{Richard Bluhm}

Growth Dynamics and Development Essays in Applied Econometrics and Political Economy

MGSoG Dissertation Series, № 54

\section{Nevena P. Zhelyazkova}

Work-Family Reconciliation and Use of Parental Leave in Luxembourg:

Empirical Analysis of Administrative Records

MGSoG Dissertation Series, № 53

\section{4}

\section{Dirk Crass}

The Impact of Brands on Innovation and Firm Performance: Empirical Evidence from Germany

UNU-MERIT Dissertation Series, № 87

\section{Samyukta Bhupatiraju}

The Geographic Dimensions of Growth and Development

UNU-MERIT Dissertation Series, № 86 


\section{François Lafond}

TheEvolution of Knowledge Systems

UNU-MERIT Dissertation Series, № 85

\section{Annalisa Primi}

Promoting Innovation in Latin

America: What Countries Have

Learned (and What They Have Not) in

Designing and Implementing

Innovation and Intellectual Property

Policies

UNU-MERIT Dissertation Series,

№ 84

\section{Fatoumata Lamarana Diallo}

Evaluation of Meal and Deworming

Programs for Primary Schools in Rural

Senegal

UNU-MERIT Dissertation Series, № 83

\section{Sachin Kumar Badkas}

Metachoice and Metadata: Innovating with Environmental Policy Analysis in Europe

MGSoG Dissertation Series, № 52

\section{Irina S. Burlacu}

An Evaluation of Tax-Benefit Systems

Impact on the Welfare of Frontier

Worker:

The Case of Luxembourg and Belgium

MGSoG Dissertation Series, № 51

\section{Özge Bilgili}

Simultaneity in Transnational

Migration Research: Links Between

Migrants' Host and Home Country

Orientation

MGSoG Dissertation Series, № 50

\section{Yulia Privalova Krieger}

Reshaping the Big Agenda:

Transnational Politics and Domestic ResistanceFinancial crisis and social protection reform in Bosnia and Herzegovina

MGSoG Dissertation Series, № 49

\section{Marieke van Houte}

Moving Back or Moving Forward?

Return migration after Conflict

MGSoG Dissertation Series, № 48

\section{Oxana Slobozhan}

Global Governance in the Management of Natural Resources: The Case of the Extractive Industries Transparency Initiative (EITI)

MGSoG Dissertation Series, № 47

\section{Luis Bernardo Mejia Guinand}

The Changing Role of the Central

Planning Offices in Latin America: A

Comparative Historical Analysis

Perspective (1950-2013)

MGSoG Dissertation Series, № 46

\section{Cheng Boon Ong}

Ethnic Segregation in Housing,

Schools and Neighbourhoods in the

Netherlands

MGSoG Dissertation Series, № 45

\section{Luciana V. Cingolani}

Bureaucracies for Development:

Oxymoron or Reality? Studies on State

Capacity in Challenging Governance

Contexts

MGSoG Dissertation Series, № 44 


\section{Carlos Cadena Gaitán}

Green Politics in Latin American

Cities - Sustainable Transport Agendas

MGSoG Dissertation Series, № 43

\section{Katie Kuschminder}

Female Return Migration and

Reintegration Strategies in Ethiopia

MGSoG Dissertation Series, № 42

\section{Metka Hercog}

Highly-Skilled Migration and New

Destination Countries

MGSoG Dissertation Series, № 41

\section{Margaret Agaba Rugadya}

Can Remittances Influence the Tenure and Quality of Housing in Uganda?

MGSoG Dissertation Series, № 40

\section{Ilire Agimi}

New Governance Under Limited

Statehood: The Case of Local

Government Reform in Kosovo

MGSoG Dissertation Series, № 39

2013

\section{Anant Kamath}

Information Sharing through Informal

Interaction in Low-Tech Clusters

UNU-MERIT Dissertation Series, № 82

\section{Flavia Pereira de Carvalho}

What we talk about when we talk about Brazilian Multinationals: An Investigation on Brazilian FDI, Economic Structure, Innovation and the Relationship between them UNU-MERIT Dissertation Series, № 81

\section{Jun Hou}

Complementarity in Innovation and Development: A Cross-country

Comparison

UNU-MERIT Dissertation Series, № 80

\section{Rufin Baghana}

Impacts of Government Incentives to $R \mathcal{E} D$, Innovation and Productivity: A Microeconometric Analysis of the Québec Case UNU-MERIT Dissertation Series, № 79

\section{Lilia I. Stubrin}

High-Tech Activities in Emerging Countries: A Network perspective on the Argentinean Biotech Activity UNU-MERIT/MGSoG Dissertation Series, № 78

\section{Kristine Farla}

Empirical Studies on Institutions, Policies and Economic Development MGSoG Dissertation Series, № 38 
Marina Petrovic

Social Assistance and Activation in the Pursuit of Happiness: Shedding New

Light on Old Policy Solutions to Social Exclusion

MGSoG Dissertation Series, № 37

\section{Laura Torvinen}

Assessing Governance Assessments:

The Case of Mozambique: Governance

Assessments in the Context of Aid

Effectiveness Discourse

MGSoG Dissertation Series, № 36

\section{Biniam Egu Bedasso}

Institutional Change in the Long

Shadow of Elite: Essays on

Institutions, Human Capital and

Ethnicity in Developing Countries

MGSoG Dissertation Series, № 35

\section{Sepideh Yousefzadeh Faal}

Deghati

Childhoods Embargoed: Constructing

and Reconstructing Multidimensional

Child Poverty in Iran 1984-2009

MGSoG Dissertation Series, № 34

\section{Robert Bauchmüller}

Investing in Early Childhood Care and Education: The Impact of Quality on Inequality

MGSoG Dissertation Series, № 33

\section{Martin Rehm}

Unified Yet Separated: Empirical

Study on the Impact of Hierarchical

Positions within Communities of

Learning

MGSoG Dissertation Series, № 32
2012

\author{
Abdul Waheed \\ Innovation Determinants and \\ Innovation as a Determinant: Evidence \\ from Developing Countries \\ UNU-MERIT Dissertation Series, \\ № 77
}

\section{Bilal Mirza}

Energy Poverty and Rural Energy

Markets in Pakistan

UNU-MERIT Dissertation Series, № 76

\section{Benjamin Engelstätter}

Enterprise Software and Video Games:

An Empirical Analysis

UNU-MERIT Dissertation Series, № 75

\section{Fulvia Farinelli}

Natural Resources, Innovation and

Export Growth: The Wine Industry in

Chili and Argentina

UNU-MERIT Dissertation Series

\section{Rodolfo Lauterbach}

Innovation in Manufacturing: From

Product Variety and Labor

Productivity Growth to Economic

Development in Chile

UNU-MERIT Dissertation Series

\section{Kirsten Wiebe}

Quantitative Assessment of

Sustainable Development and Growth in Sub-Saharan Africa

UNU-MERIT Dissertation Series, № 74 


\section{Julio Miguel Rosa}

Organizational Strategies, Firms'

Performance and Spatial Spillovers:

The Canadian Case in Research and

Development.

UNU-MERIT Dissertation Series, № 73

Johannes Wilhelmus Marie Boels

Joseph Schumpeter, Honderd Jaar

Economische Ontwikkeling: Een

Historisch-theoretische Beschouwing.

UNU-MERIT Dissertation Series

\section{Dorcas Mbuvi}

Utility Reforms and Performance of the

Urban Water Sector in Africa

MGSoG Dissertation Series, № 31

\section{Lina Salanauskaite}

Distributional Impacts of Public

Policies: Essays in Ex-Ante and Ex-

Post Evaluation

MGSoG Dissertation Series, № 30

\section{Esther Schüring}

To Condition or not - is that the

Question?

An Analysis of the Effectiveness of ExAnte and Ex-Post Conditionality in

Social Cash Transfer Programs

MGSoG Dissertation Series, № 29

\section{Joe Abah}

Strong Organisations in Weak States:

Atypical Public Sector Performance in

Dysfunctional Environments

MGSoG Dissertation Series, № 28

\section{Zina Samih Nimeh}

Social Citizenship Rights: Inequality

and Exclusion

MGSoG Dissertation Series, № 27

2011

\section{Daniel Vertesy}

Interrupted Innovation: Emerging

Economies in the Structure of the

Global Aerospace Industry

UNU-MERIT Dissertation Series, № 72

\section{Tina Saebi}

Successfully Managing Alliance

Portfolios: AnAlliance Capability View UNU-MERIT Dissertation Series, № 71

\section{Nora Engel}

Tuberculosis in India: A Case of Innovation and Control

UNU-MERIT/MGSoG Dissertation

Series, № 70

\section{Evans Mupela}

Connectivity and growth in Sub-

Saharan Africa: The Role of

Communication Satellites

UNU-MERIT Dissertation Series,

№ 69

\section{Nantawan Kwanjai}

Cross Cultural Intelligence amid

Intricate Cultural Webs: A Tale of the

UnDutchables in the Land of 1002

Smiles

UNU-MERIT Dissertation Series, № 68 


\section{Lina Sonne}

Innovation in Finance to Finance

Innovation: Supporting Pro-poor

Entrepreneur-based Innovation

UNU-MERIT Dissertation Series, № 67

\section{Lenka Eisenhamerová}

Legitimacy of 'Humanitarian Military

Intervention'

MGSoG Dissertation Series, № 26

\section{Sonila Tomini}

Informal Payments for Health Care

Services in Albania

MGSoG Dissertation Series, № 25

\section{Jinjing Li}

Dynamic Microsimulation in Public

Policy Evaluation

MGSoG Dissertation Series, № 24

\section{Aziz Atamanov}

Rural Nonfarm Employment and

International Migration as

Alternatives to Agricultural

Employment: The Case of Kyrgyzstan

MGSoG Dissertation Series, № 23

\section{Frieda Vandeninden}

Poverty Alleviation: Aid and Social

Pensions

MGSoG Dissertation Series, № 22

\section{Juliana Nyasha Tirivayi}

The Welfare Effects of Integrating

AIDS Treatment with Food Transfers:

Evidence from Zambia

MGSoG Dissertation Series, № 21

\section{Agnieska Ewa Sowa}

Who's Left Behind? Social Dimensions

of Health Transition and Utilization of

Medical Care in Poland

MGSoG Dissertation Series, № 20

\section{Emmanaouil Sfakianakis}

The Role of Private Actors in the

Provision of Public Goods with

Applications to Infrastructure and

Financial Stability

MGSoG Dissertation Series, № 19

\section{Siu Hing Lo}

White Collars Green Sleeves: An Interorganizational Comparison of

Determinants of Energy-Related

Behaviors among Office Workers

MGSoG Dissertation Series, № 18

\section{Treena Wu}

Constraints to Human Capital

Investment in Developing Countries:

Using the Asian Financial Crisis in

Indonesia as a Natural Experiment

MGSoG Dissertation Series, № 17

\section{Henry Espinoza Peña}

Impact Evaluation of a Job-Training

Programme for Disadvantaged Youths:

The Case of Projoven

MGSoG Dissertation Series, № 16 


\section{Asel Doranova}

\section{Fernando Santiago}

Human Resources Management

Practices and Learning for Innovation

in Developing Countries:

Pharmaceutical Firms in Mexico

UNU-MERIT Dissertation Series, № 66

\section{Zakaria Babutsidze}

Essays on Economies with

Heterogeneous Interacting Consumers

UNU-MERIT Dissertation Series, № 65

\section{Bertha Vallejo}

Learning and Innovation Under

Changing Market Conditions: The

Auto Parts Industry in Mexico

UNU-MERIT Dissertation Series, № 64

\section{Donatus Ayitey}

Technical Change, Competitiveness

and Poverty Reduction: A Study of the

Ghanaian Apparel Industry

UNU-MERIT Dissertation Series, № 63

\section{Sergey Filippov}

Multinational Subsidiary Evolution:

Corporate Change in New EU Member

States

UNU-MERIT Dissertation Series, № 62
Technology Transfer and Learning

under the Kyoto Regime: Exploring the Technological Impact of CDM Projects in Developing Countries

UNU-MERIT Dissertation Series, № 61

\section{Florian Tomini}

Between Family and Friend:

Understanding the Interdependency of Private Transfers

MGSoG Dissertation Series, № 15

\section{Michał Polalowski}

The Institutional Transformation of

Social Policy in East Central Europe:

Poland and Hungary in Comparative and Historical Perspective

MGSoG Dissertation Series, № 14

\section{Maha Ahmed}

Defining, Measuring and Addressing

Vulnerability: The Case of Post

Conflict Environments

MGSoG Dissertation Series, № 13

\section{Pascal Beckers}

Local Space and Economic Success:

The Role of Spatial Segregation of Migrants in the Netherlands

MGSoG Dissertation Series, № 12

\section{Victor Cebotari}

Conflicting Demands in Ethnically

Diverse Societies: Ethno political

Contention and Identity Values in

Europe

MGSoG Dissertation Series, № 11 
Dennis Gyllensporre

Competing and Complementary

Perspectives on the EU as a Crisis

Management Actor:

An Examination of the Common

Security and Defence Policy through

the Lenses of Idealism and Realism

MGSoG Dissertation Series, № 10

Judit Vall Castello

Business Cycle and Policy Effects on Labour Market Transitions of Older and Disabled Workers in Spain

MGSoG Dissertation Series, № 9

\section{Keetie Roelen}

False Positives or Hidden Dimensions:

The Definition and Measurement of

Child Poverty

MGSoG Dissertation Series, № 8

Denisa Maria Sologon

Earning Dynamics in Europe

MGSoG Dissertation Series, № 7

\section{Melissa Siegel}

Money and Mobility: Migration and

Remittances

MGSoG Dissertation Series, № 6

Jessica S. Hagen-Zanker

Modest Expectations: Causes and

Effects of Migration on Migrant

Households inSource Countries

MGSoG Dissertation Series, № 5
2009

\begin{abstract}
Alexis Habiyaremye
From Primary Commodity Dependence to Diversification and Growth:

Absorptive Capacity and Technological Catch Up in Botswana and Mauritius.

UNU-MERIT Dissertation Series,

№ 60
\end{abstract}

\section{Yoseph Getachew}

The Role of Public Capital in Economic Development

UNU-MERIT Dissertation Series, № 59

\section{Sandra Leitner}

Embodied Technological Change and

Patterns of Investment in Austrian

Manufacturing

UNU-MERIT Dissertation Series,

№ 58

\section{Semih Akçomak}

The Impact of Social Capital on

Economic and Social Outcomes

UNU-MERIT Dissertation Series, № 57

\section{Abraham Garcia \\ The Role of Demand in Technical \\ Change \\ UNU-MERIT Dissertation Series, № 56}

\section{Saurabh Arora}

Coherence in Socio-technical Systems:

A Network Perspective on the Innovation Process

UNU-MERIT Dissertation Series, № 55 


\section{Mirtha R. Muniz Castillo}

Human Development and Autonomy

in Project Aid: Experiences from four

bilateral projects in Nicaragua and $E l$

Salvador

MGSoG Dissertation Series, № 4

\section{Christiane Arndt}

Governance Indicators

MGSoG Dissertation Series, № 3

\section{Britta Augsburg}

Microfinance: Greater Good or Lesser

Evil?

MGSoG Dissertation Series, № 2

2008

\section{Rutger Daems}

Medicines for the Developing World

UNU-MERIT Dissertation Series, № 54

\section{Johannes Hanel}

Assessing Induced Technology:

Sombart's Understanding of Technical

Change in the History of Economics

UNU-MERIT Dissertation Series,

№ 53

\section{Rifka Weehuizen}

Mental Capital: the Economic

Significance of Mental Health

UNU-MERIT Dissertation Series,

№ 52

\section{Danielle Cloodt}

The Relationship between RED

Partnership Formation, Social

Embeddedness and Innovative

Performance

UNU-MERIT Dissertation Series, № 51

\section{Sabine Fuss}

Sustainable Energy Development

under Uncertainty

UNU-MERIT Dissertation Series,

№ 50

\section{Geranda Notten}

Measuring and Managing Poverty

Risks

MGSoG Dissertation Series, № 1

2007

\section{Tobias Kronenberg}

Reconciling Environmental

Conservation with Economic

Prosperity: The Feasibility of Double

Dividends in the Short and Long Run

UNU-MERIT Dissertation Series,

№ 49

\section{Viktoria Kravtsova}

Assessing the Impact of Foreign Direct Investment in Transition Economies UNU-MERIT Dissertation Series, № 48 


\section{Suhail Sultan}

The Competitive Advantage of Small and Medium Sized Enterprises: The Case of Jordan's Natural Stone Industry

UNU-MERIT Dissertation Series, № 47

2006

\section{Bulat Sanditov}

Essays on Social Learning and Imitation

UNU-MERIT Dissertation Series, № 46

\section{Mamata Parhi}

Dynamics of New Technology Diffusion: A Study of the Indian Automotive Industry

UNU-MERIT Dissertation Series, № 45

\section{Andreas Reinstaller}

Social Structures and the Innovation Process: Their Role in the Demand of Firms and Consumers

UNU-MERIT Dissertation Series, № 44

\section{Rose Kiggundu}

Innovation systems and Development:

The Journey of a Beleaguered Nile

Perch Fishery in Uganda

UNU-MERIT Dissertation Series, № 43

\section{Thomas Pogue}

The Evolution of Research

Collaboration in South African Gold Mining: 1886-1933

UNU-MERIT Dissertation Series, № 42

\section{Geoffrey Gachino}

Foreign Direct Investment, Spillovers and Innovation: The Case of Kenyan Manufacturing Industry UNU-MERIT Dissertation Series, № 41

\section{Önder Nomaler}

Technological Change, International Trade and Growth: An Evolutionary, Multi-Agents-Based Modeling

Approach

UNU-MERIT Dissertation Series, № 40

2005

Samia Satti Osman Mohamed-

Nour

Change and Skill Development in the Arab Gulf Countries

UNU-MERIT Dissertation Series, № 39

\section{Elad Harison}

Intellectual Property Rights:

Economics and Policy Analysis UNU-MERIT Dissertation Series, № 38 


\section{Daniel Dalohoun}

The Relationship between RED

Partnership Formation, Social

Embeddedness and Innovative

Performance: a Multi-level Approach of Social Embeddedness

UNU-MERIT Dissertation Series, № 37

\section{Müge Ozman}

Networks, Organizations and

Knowledge

UNU-MERIT Dissertation Series,

№ 36

\section{Bas Straathof}

Product Variety and Economic

Growth: The Counteracting Effects of

Scale and Idiosyncrasy

UNU-MERIT Dissertation Series,

№ 35

\section{Wilfred Schoenmakers}

Knowledge Flows between

Multinational Companies: A Patent

Data Analysis

UNU-MERIT Dissertation Series, № 34

\section{Myriam Cloodt}

Mergers and Acquisitions ( $M$ and As) in High-Tech Industries: Measuring the Post-M and A Innovative

Performance of Companies

UNU-MERIT Dissertation Series, № 33
2004

\section{Paola Criscuolo}

RED Internationalisation and

Knowledge Transfer: Impact on MNEs

and their Home Countries

UNU-MERIT Dissertation Series,

№ 32

\section{Maarten Verkerk}

Trust and Power on the Shop Floor UNU-MERIT Dissertation Series, № 31

\section{Gottfried Leibbrandt}

Adoption, Harmonization and

Succession of Network Technologies across Countries

UNU-MERIT Dissertation Series, № 30

\section{Mark Sanders}

Skill Biased Technical change: Its Origins, the Interaction with the Labour Market and Policy Implications UNU-MERIT Dissertation Series, № 29

2003

\section{Nadine Roijakkers}

Inter-firm Cooperation in High-tech Industries: a Study of RED

Partnerships in Pharmaceutical

Biotechnology

UNU-MERIT Dissertation Series, № 28 
Viki Sonntag

Speed, Scale and Sustainability

UNU-MERIT Dissertation Series, № 27

\section{Masaru Yarime}

From End-of-Pipe Technology to Clean

Technology

UNU-MERIT Dissertation Series,

№ 26

\section{Stéphane Malo}

The Combinatorial Chemistry

Revolution: Sustaining a Superior

Performance Position through

Technological Learning

UNU-MERIT Dissertation Series,

№ 25

\section{2}

\section{Annelies Hogenbirk}

Determinants of Inward Foreign

Direct Investment: the Case of the

Netherlands

UNU-MERIT Dissertation Series, № 24

\section{Bastiaan Johan terWeel}

The Computerization of the Labour Market

UNU-MERIT Dissertation Series
2001

\section{John Adeoti}

Technology Investment in Pollution Control in Sub-Saharan Africa: The Case of the Nigerian Manufacturing Industry

UNU-MERIT Dissertation Series, № 23

\section{Edward Huizenga}

Innovation Management: How

Frontrunners Stay Ahead: An

Empirical Study on Key Success

Factors in the ICT sector

UNU-MERIT Dissertation Series, № 22

\section{0}

\section{Machiel van Dijk}

Technological Change and the Dynamics of Industries: Theoretical Issues and Empirical evidence from Dutch Manufacturing UNU-MERIT Dissertation Series, № 21

\section{9}

\section{Jan Cobbenhagen}

Managing Innovation at the Company Level: A Study on Non-Sector-Specific Success Factors UNU-MERIT Dissertation Series, № 20 
Marjolein Caniëls

Regional Growth Differentials: The

Impact of Locally Bounded Knowledge

Spillovers

UNU-MERIT Dissertation Series, № 19

1998

\begin{abstract}
Aldo Geuna
Resource Allocation and Knowledge production: Studies in the Economics of University Research UNU-MERIT Dissertation Series, № 18
\end{abstract}

1996

\section{Reinoud Joosten}

Dynamics, Equilibria, and Values UNU-MERIT Dissertation Series, № 17

\section{Hugo Kruiniger}

Investment, $R \mathcal{E} D$, and the Financing

Decisions of the Firm

UNU-MERIT Dissertation Series, № 16

\section{5}

\section{Hans van Meij1}

Endogenous Technological Change:

The Case of Information Technology,

Theoretical Considerations and

Empirical Results

UNU-MERIT Dissertation Series, № 15

\section{René Kemp}

Environmental Policy and Technical

Change: A Comparison of the

Technological Impact of Policy

Instruments

UNU-MERIT Dissertation Series, № 14

\section{Rohini Acharya}

The Impact of New Technologies on Economic Growth and Trade: A Case Study of Biotechnology

UNU-MERIT Dissertation Series, № 13

\section{Geert Duysters}

The Evolution of Complex Industrial Systems: The Dynamics of Major IT Sectors

UNU-MERIT Dissertation Series, № 12

\section{Marjan Groen}

Technology, Work and Organisation: A Study of the Nursing Process in Intensive Care Units

UNU-MERIT Dissertation Series, № 11

\section{4}

\section{Huub Meijers}

On the Diffusion of Technologies in a Vintage Framework: Theoretical Considerations and Empirical Results UNU-MERIT Dissertation Series, № 10 
Theon van Dijk

The Limits of Patent Protection: Essays on the Economics of Intellectual

Property Rights

UNU-MERIT Dissertation Series, № 9

\section{Hans Voordijk}

Naar Integrale Logistiek in

Bedrijfsketens: Ontwikkelingen in de Bouw

UNU-MERIT Dissertation Series, № 8

1993

\section{Paul Diederen}

Technological Progress in Enterprises and Diffusion of Innovation:

Theoretical Reflections and Empirical

Evidence

UNU-MERIT Dissertation Series, № 7

\section{Ben Dankbaar}

Economic Crisis and Institutional Change: The Crisis of Fordism from the Perspective of the Automobile Industry UNU-MERIT Dissertation Series, № 6

\section{Hanno Roberts}

Accountability and Responsibility: The Influence of Organisation Design on Management Accounting UNU-MERIT Dissertation Series, № 5
1992

\section{Bart Verspagen}

Uneven Growth between

Interdependent Economies: An

Evolutionary View on Technology

Gaps, Trade and Growth

UNU-MERIT Dissertation Series,

№ 4

\section{Sjoerd Romme}

A Self-organization Perspective on

Strategy Formation

UNU-MERIT Dissertation Series, № 3 


\section{John Spangenberg}

Economies of Scale, and Atmosphere in

Research Organisations

UNU-MERIT Dissertation Series,

№ 2

1988

\section{John Hagedoorn}

Evolutionary and Heterodox

Innovation Analysis: A Study of

Industrial and Technological

Development in Process Control and

Information Technology

UNU-MERIT Dissertation Series,

№ 1 